




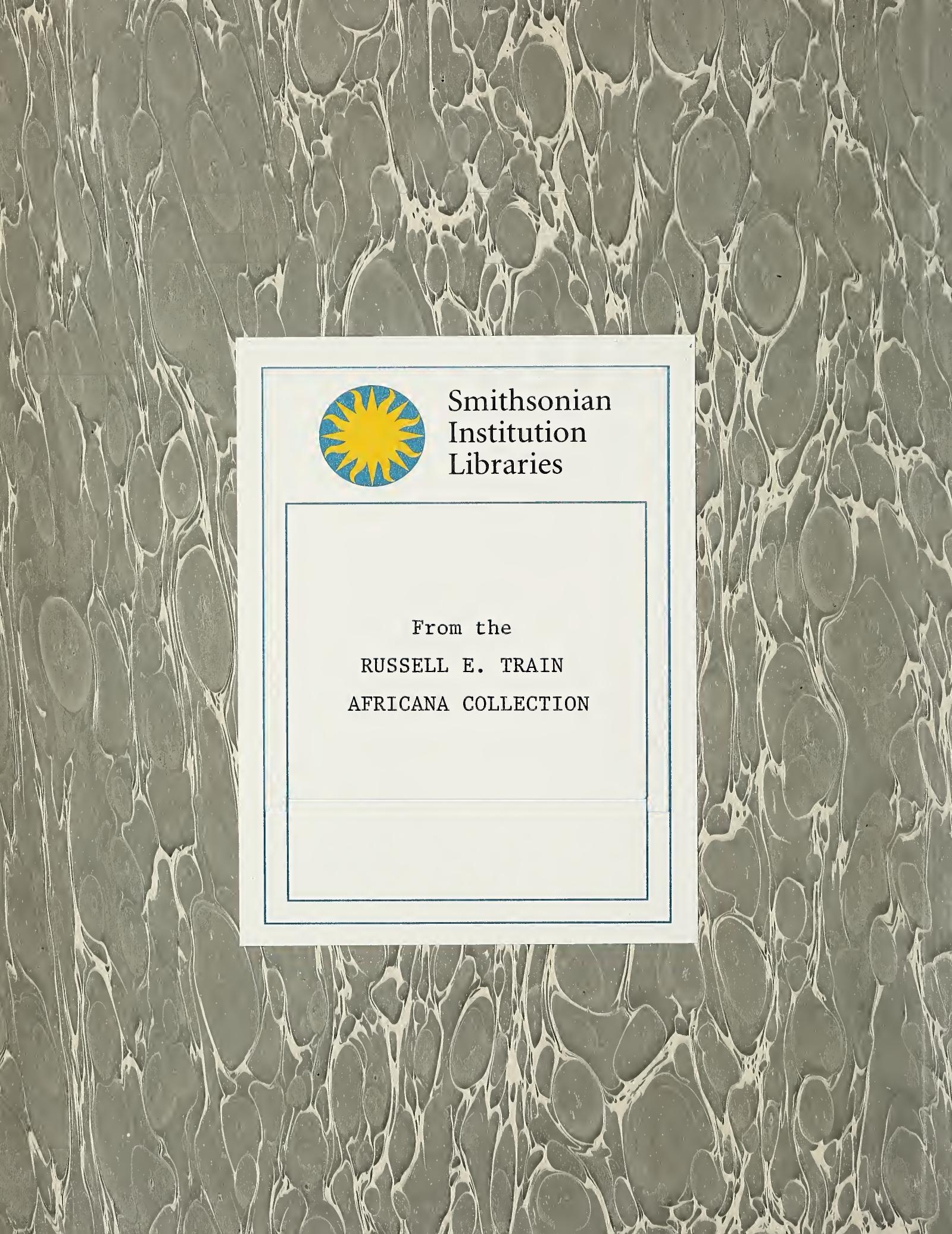


LE. -
$1086 \mathrm{rat}$

fts 



\section{DIARY OF A TOUR \\ IN SOUTH AFRICA}






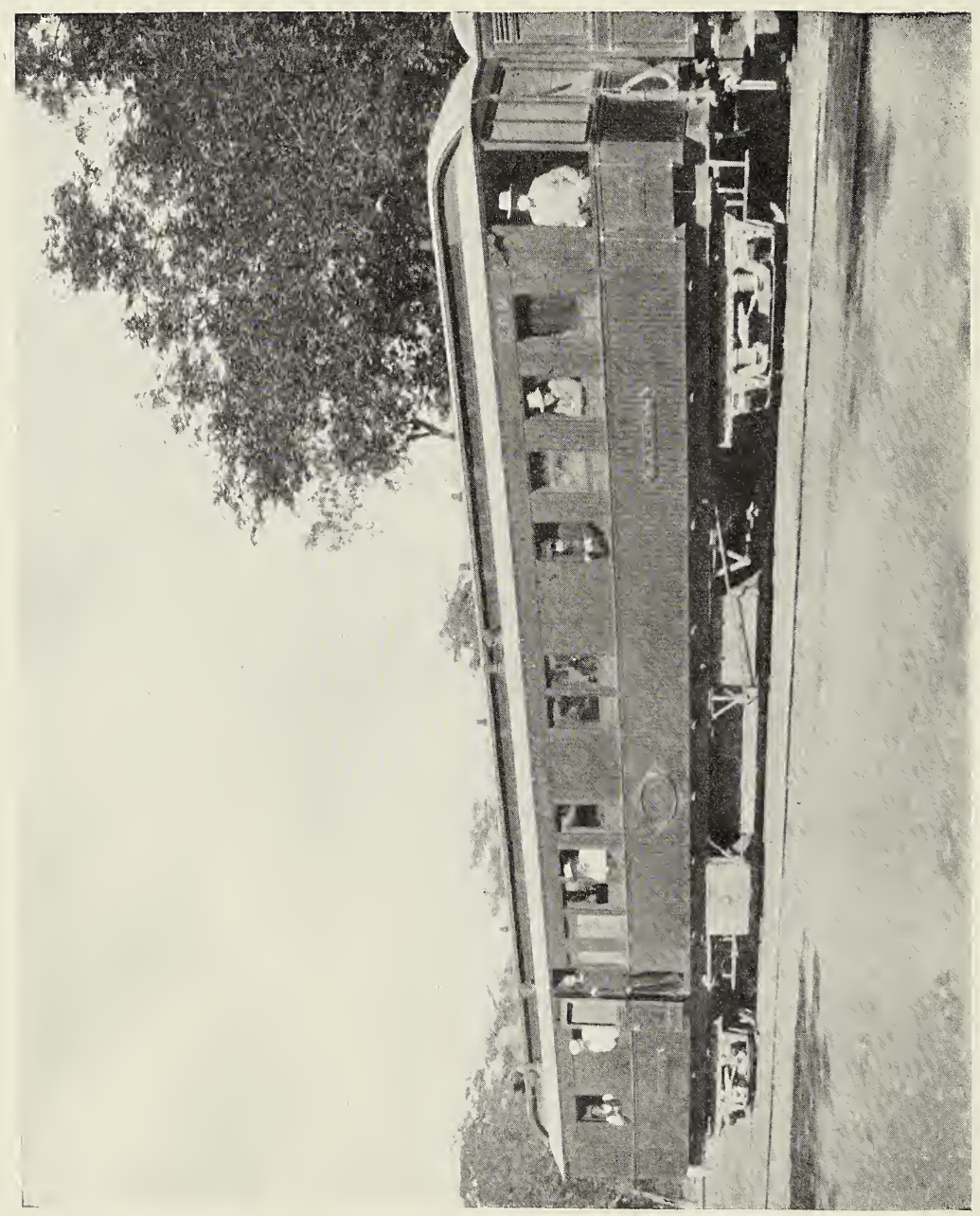




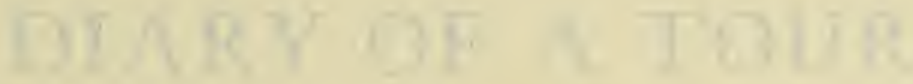

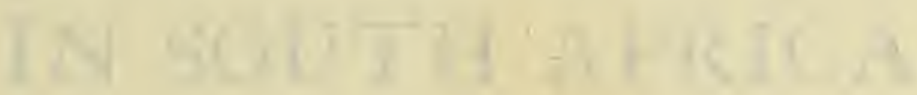

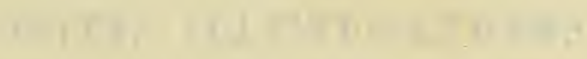

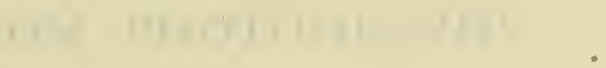

Shes $3 \times 17149$ it 10 
OUR PRIVATE CAR. 


\title{
DIARY OF A TOUR IN SOUTH AFRICA
}

\author{
WITH ILLUSTRATIONS \\ FROM PHOTOGRAPHS
}

\author{
BY \\ W. Agate, Mus. B. Oxon., F.R.C.O.
}

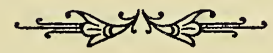

\section{PAISLEY}

Printed for Private Circulation by Alex. Gardner

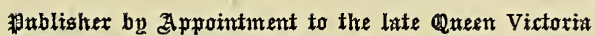
1912 



\section{PREFACE.}

By way of a preface to this Diary, I must mention my indebtedness to my friend and travelling companion J. B. Hilliard, for the description of the "Crew," commencing "The huge nigger" (page I4I) to "joined the majority" (page I44); also, his admirable testimonial to our "Chaplain" (pages I94 and I95).

In addition, my thanks are due to Mr. Percy M. Clark, photographer of the Victoria Falls, for permission to make reproductions of five (Nos. 50, 5I, 53, 55, and 59) of the excellent pictures we obtained from him of the Falls and bridge when there; and which I should have been unable to get myself, owing to the enormous amount of spray, that made photo- 
graphy impossible at these points, at the time of our visit.

My thanks are also due to the Administration of the South African Railways, for permission to make reproductions of three Cape Government Railway's photographs (Nos. 8, 9, and i I).

The remaining sixty-three pictures contained in this volume are reproductions from my own negatives.

W. A.

Hilden,

Paisley, 1912. 


\section{LIST OF ILLUSTRATIONS.}

PAGE

I. Our Private Car, _ $\quad$ - $\quad$ - $\quad$ - $\quad$ - $\quad$ - Frontispiece

2. A Farewell Group, - $\quad$ - $\quad$ - $\quad$ - facing 18

3. Group on Boat-deck, S. S. Briton, - - ?

4. Cricket at Sea, _ _ _ _ _ _ $\quad-\} \geqslant 20$

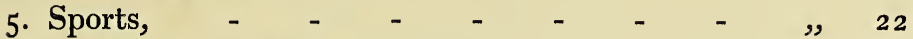

6. Drive Round Table Mountain, - - - $\}$

7. Peaks of "The Twelve Apostles," - _ _

8. The Devil's Peak, Cape Town, - - - „ 32

9. Table Mountain and Cape Town, -
ı. The Car Staff and the Whipper-in, -

I I. The Hex River Pass, - $\quad$ - $\quad$ - $\quad$, 40

I2. Entrance to the Cango Caves, - - - , , 48

I3. On the Way to the Cango Caves, - - , 50

14. Kaffir Cooks at the Caves, - - - - $\}$, 52

I5. Lunch at the Caves, - $\quad-\quad-\quad-\}$ " 52

r6. Feeding Ostriches with Lucerne, - - $\quad$, 54

I7. A Block House-a Reminiscence of the Boer

$$
\text { War, - } \quad \text { - } \quad \text { - } \quad \text { - } \quad \text { - } \quad \text { - } \quad \text { - } \quad \text {, } 56
$$


PAGE

I8. Mr. Andrew Coats' Home at Kubusie, - - facing 62 I9. Bloemfontein, - $\quad$ - $\quad$ - $\quad$ - $\quad$, , 64

20. Basutos and Hunting-Dogs, - - - , 66

21. Ladysmith, from Convent Hill,
22. Spion Kop,

23. Thornycroft's Position-Summit of Spion Kop, „, 70

24. Battlefield of Colenso, - $\quad$ - $\quad$ - $\quad$, 72

25. Kaffir's Hut-Colenso, - $\quad$ - $\quad$ - $\quad$, 74

26. Pier and Shark-proof Bathing Station, Durban, )

27. Jinricshaws at Durban, _ _ _ _ _ $\}$ „ 76

28. A Promenade à Jinricshaw, - - _ „ , 76

29. Starting from Ginginhlovu for Eshowe, - , 78

30. Eshowe, the Capital of Zululand, - - , , 80

31. Robinson's Deep Gold Mine, Johannesburg, , 88

32. Surface Workings, Robinson's Deep, - - , 90

33. Church Square, Pretoria, - $\quad$ - $\quad$ - , 92

34. Entrance to French Bob's Mine, - - , 98

35. War Dance of the Swazis, - - - - $\}, 100$

36. A Swazi Siesta, - _ _ _ _ _ _ _

37. Mafeking, from Roof of Town Hall, - - , 102

38. Shooting Party, near Mafeking, - - - „ I Io

39. Lunch on the Veldt, - $\quad$ - $\quad$ - $\quad$ - , II2

40. Bulawayo-Rhodes's Statue,
41. The Dam-Motoppo Hills, 
42. Cecil Rhodes's Last Resting-Place, - - facing 120 43. The Grave and its Guardian, - _ _ _, 122

44. The Allan Wilson Monument-Motoppo Hills, „, I26 45. The Annex-Victoria Falls Hotel, - 46. The Gorge of the Zambesi and Bridge, 47. The Whirlpool below Bridge, from Palm Kloof, 48. Rapids above Eastern Cataract-Victoria Falls,

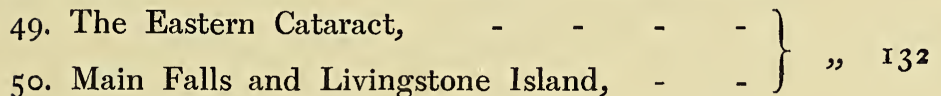
51. Rainbow Falls and Danger Point, - 52. Rapids above Leaping Water-Victoria Falls, 53. Bridge over the Zambesi-Height, 420 feet, $\}$ "I I34 54. A Trip over Bridge with Resident Engineer,

55. The Chasm-Victoria Falls, - $\quad$ - $\quad$ „ 138 56. Visit to Kandahar Island, - _ _ _ - , 142 57. Tropical Foliage at Kandahar Island, - - „ „ 144 58. A Famous Baobab Tree, - - _ - _ „, 146 59. The Entrance to the Gorge, - - - „ I50 60. Livingstone Station, - $\quad$ - $\quad$ - $\quad$ - $\quad$ „ 152 6r. The Floods at the Kafue River, - _ „ 62. A Summer Residence in the Rhodesian Forest, - $\quad$ - $\quad$ - $\quad$ - $\quad$ - $\quad$ - y $\quad$ I60 63. The Wesselton Diamond Mine (De Beers), Kimberley, - $\quad$ - $\quad$ - $\quad-\quad$ - $\quad$ - $\quad$, $\quad$ r68 
PAGE

64. Indian Ocean, from Schumacher's Kop, Port

Elizabeth, - - - - - - facing 176

65. View of Cape Point (Cape of Good Hope), from Miller's Point, - $\quad$ - $\quad$ - $\quad$, 184

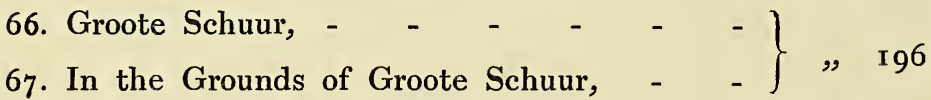
68. At Funchal, Madeira, - $\quad$ - $\quad$ - 206

69. A Hard-working Quartet, - - _ _ , 210

70. A "Promenade" at Simon's Town, South Africa, - $\quad$ - $\quad$ - $\quad$ - $\quad$ - , 2 I2

7I. A "Promenade" at Embley Park, Hants, - $\int$ " 212 


\section{DIARY OF A \\ Tour in South Africa.}

THIS record of the experiences of a party of four, who left this country on March I 3 th, I909, for a Tour in Cape Colony, Natal, Zululand, the Orange River Colony, the Transvaal, and Southern and North-Western Rhodesia, makes no pretence to be anything but a simple account of their doings over a period of about four months, and must be regarded and tolerated, by those who may have the requisite patience and endurance to wade through it, as a necessary adjunct to the illustrations which have been reproduced from some of the hundreds of negatives obtained en route.

2 
i4 Diary of a Tour in South Africa.

My introduction to this "little jaunt" came about in this way. During the late autumn of 1908, the Laird of Woodside and elsewhere happened to be spending a day or two with us at Hilden (his own household being at the time in a migratory state 'twixt Battleby and Woodside), and at the close of an evening, which my guest had pretty fairly divided between the Evening Citizen and numerous excursions into dreamland, suddenly, just about midnight, roused himself from a fairly comfortable nap, and without any preliminaries said :"Do you think you can manage to go with my brother Dan and me for a fairly long tour in South Africa?"

As I had already in the past managed a few items in the domain of travel-a process which begets an appetite for more nourishment of the same kind-I felt I could assimilate another odd continent or two, if necessary, and I think at once indicated that if this proposed little trip 
Diary of a Tour in South Africa. 15

came off, I could be relied upon to be there. To cut these introductory preliminaries short, I may say that a little later on the undertaking evolved itself in a more complete form, and it became an accepted fact that we should sail for Cape Town early in March.

The "we," I may here say, consisted of our two hosts, the Laird and his brother, Mr. Dan (with both of whom it had already been my good fortune to travel in latitudes extending from the borders of the Sudan to the North Cape); J. B. Hilliard, medical adviser, conversationalist, etc., etc. (known throughout our travels as the "Professor"); and myself, photographer and general jobber to the expedition, often dubbed by my travelling companions as that "Precious Stone." Our operations really sprang into existence in the month of February, when the four of us, accompanied by the Laird's man Guntrip (who was also to be of the party), went to London for the pur- 
i6 Diary of a Tour in South Africa.

pose of buying arms and ammunition, and great quantities of other kinds of gear, considered necessary for our comfort-cigars and tobacco forming no inconsiderable portion of our general stores, and in the consumption of which, at a later stage, the "Professor" and that "Precious Stone" were held to be veritable experts.

In the aforesaid transactions, we had the valuable assistance of Major Chichester, who, with his wife, had joined us at the Hotel Metropole.

Most of our time in London was spent at the Army and Navy Stores, with one afternoon at a range belonging to that company, where we tested rifles, etc., and I, at any rate (more accustomed to aiming with a camera than a rifle), contracted rather a painful shoulderone of those rifles being of considerable calibre, and guaranteed by the sellers as capable of "stopping" any known quadruped, presumably, the personal equation having some influence in this matter! The strain of these proceedings 
Diary of a Tour in South Africa. i 7

was relieved by visits to the theatre both nights we were in town.

On our return to Paisley the question of suitable "clo" " had to be considered, and as is usual in these cases, speaking for myself, I took much more with me than I needed. The remaining time at home soon sped, and on the morning of March 9th, I found myself saying "good-bye" to my household "gods," or rather, "goddesses," as I had to go south in advance of my travelling companions, in order to say farewell to my youngest girl, at school in Harrogate, and my Hampshire relatives generally; and on the I 2 th, joined the other members of the party at Embley Park, the charming home of Major and Mrs. Chichester. A farewell dinner was the event of that evening, at which were present Mr. and Mrs. Harker and Evie, in addition to our hosts and our four selves.

The Major had most thoughtfully arranged for dinner-table decorations of the Noah's Ark 
i 8 Diary of a Tour in South Africa.

type, with, I suppose, the amiable intention of foreshadowing the terrific onslaught we were likely to make on the larger fauna of South Africa-elephants, lions, leopards, and such like denizens of the jungle, disporting themselves amidst beautiful flowers and foliage, not exactly of the jungle type. Several speeches of the "hope-you'll-get-back-all-right" order were made, and replied to in the sense that we all intended to do so, if possible; and our last evening, for the present, in old England came to an end with mutual good wishes all round.

\section{March I 3.}

As we begin our travels to-day, I had now better keep the story of them in diary form.

The start from Embley was really a most imposing affair: three motor-cars taking us, our friends, and our hand baggage to Southampton, the first stage of our long journey; and many a time in the next month or two, 
A FAREIVELL GROUP. 



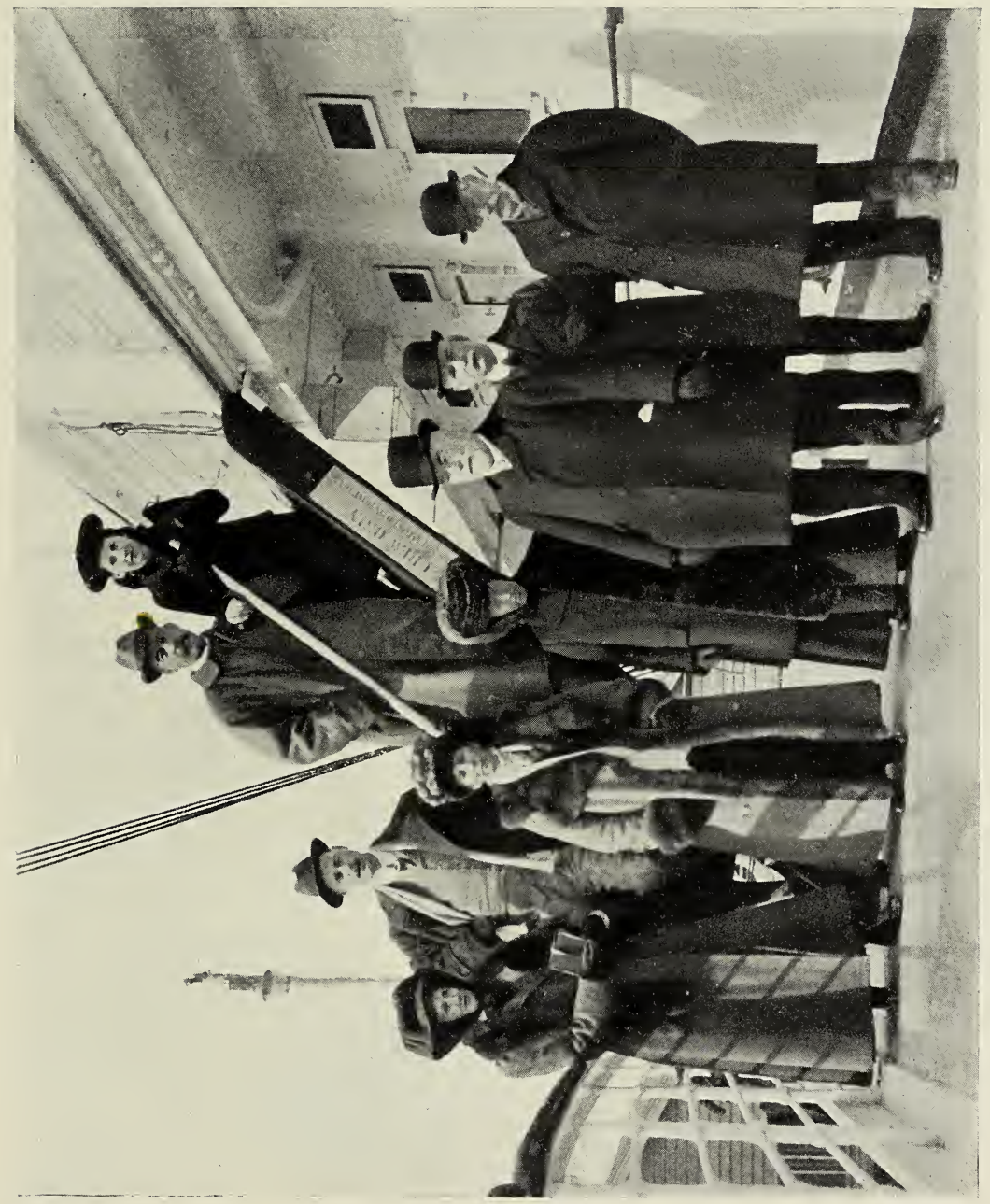



Diary of a Tour in South Africa. I9

when in process of dismemberment on the so-called roads of South Africa, I thought of that Hampshire road, 6,000 miles distant, and was glad that ere long it would be my lot to see a decent road again. Not that South Africa hasn't in places good roads; but they are often ghastly parodies.

We reached the s.s. Briton of the Union Castle Fleet about II.3O, and found she would not sail till about 4 o'clock. The Laird's man, Guntrip, very soon appeared on the scene, with the welcome intelligence that our trunks, which he had brought down to Southampton the previous evening, had all been stowed away in our several cabins.

Most of us then made a tour of the ship, in which, we soon came to the conclusion, we should have no difficulty in making ourselves comfortable for the next seventeen days. A farewell group taken on the promenade deck formed a conclusion to our inspection; and the 
20 Diary of a Tour in South Africa.

accompanying reproduction shews what is sometimes possible in photography, as the light conditions at the time it was taken could have been described as "indifferent to bad": the result being one of the very best group negatives it has been my luck to get.

Having all lunched together on board, we said a final good-bye to all our friends, including Mr. John Millar, who had suddenly appeared on the scene; and they having all departed, we felt that our travels had now really begun. We spent the afternoon sending off farewell telegrams, and watching other people's farewells. A few were sad, and some extremely grotesque-in cases where the voyagers and their friends (I suppose, owing to the long wait) had managed to get tolerably drunk. I remember one very fat woman, who not only kept embracing the man who was sailing, but also every other man that happened to come within range. As the ship got under weigh, 
GROUP ON BOAT-DECK, S.S. "BRITON." 


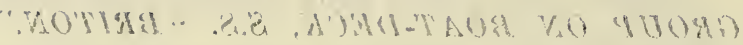




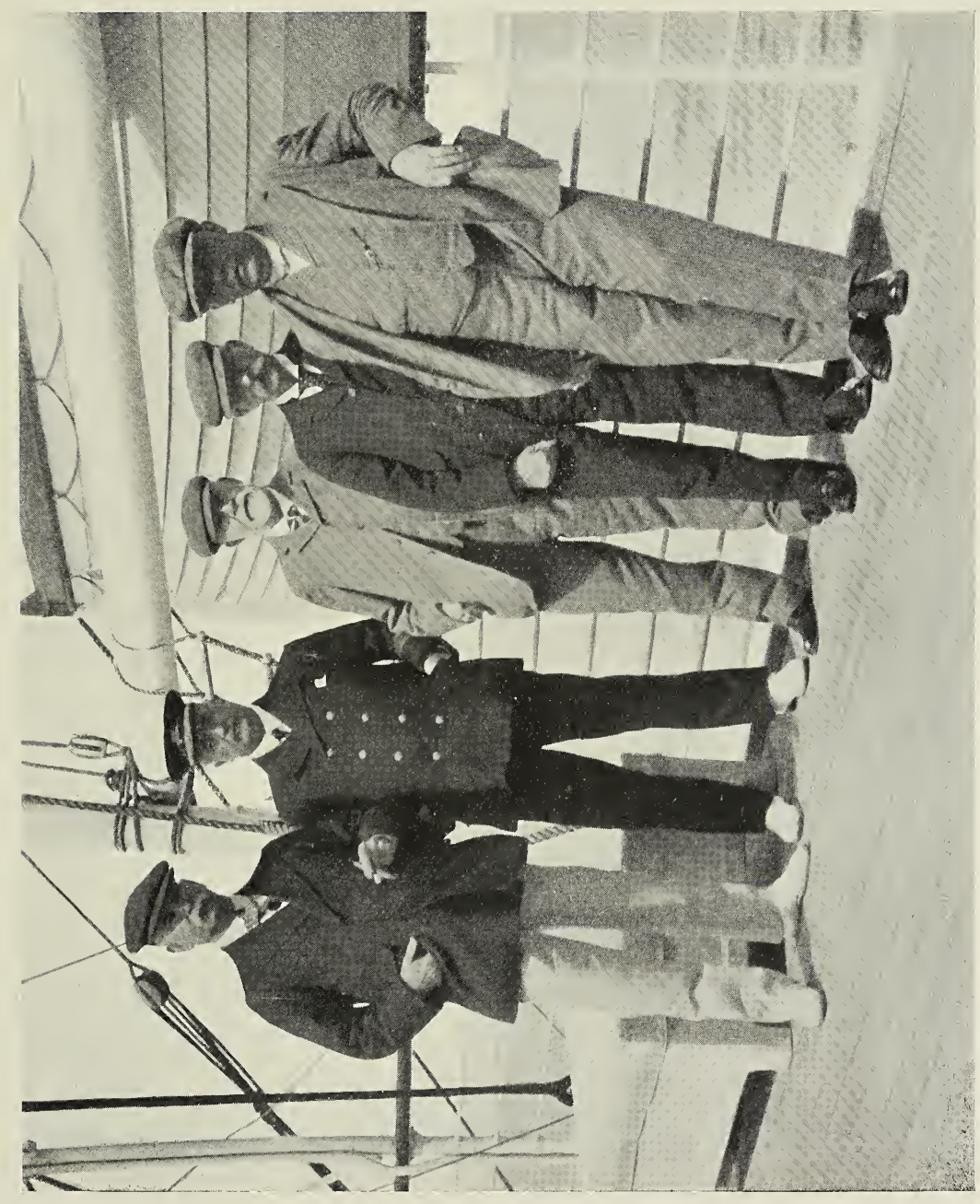



CRICKET AT SEA. 


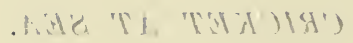




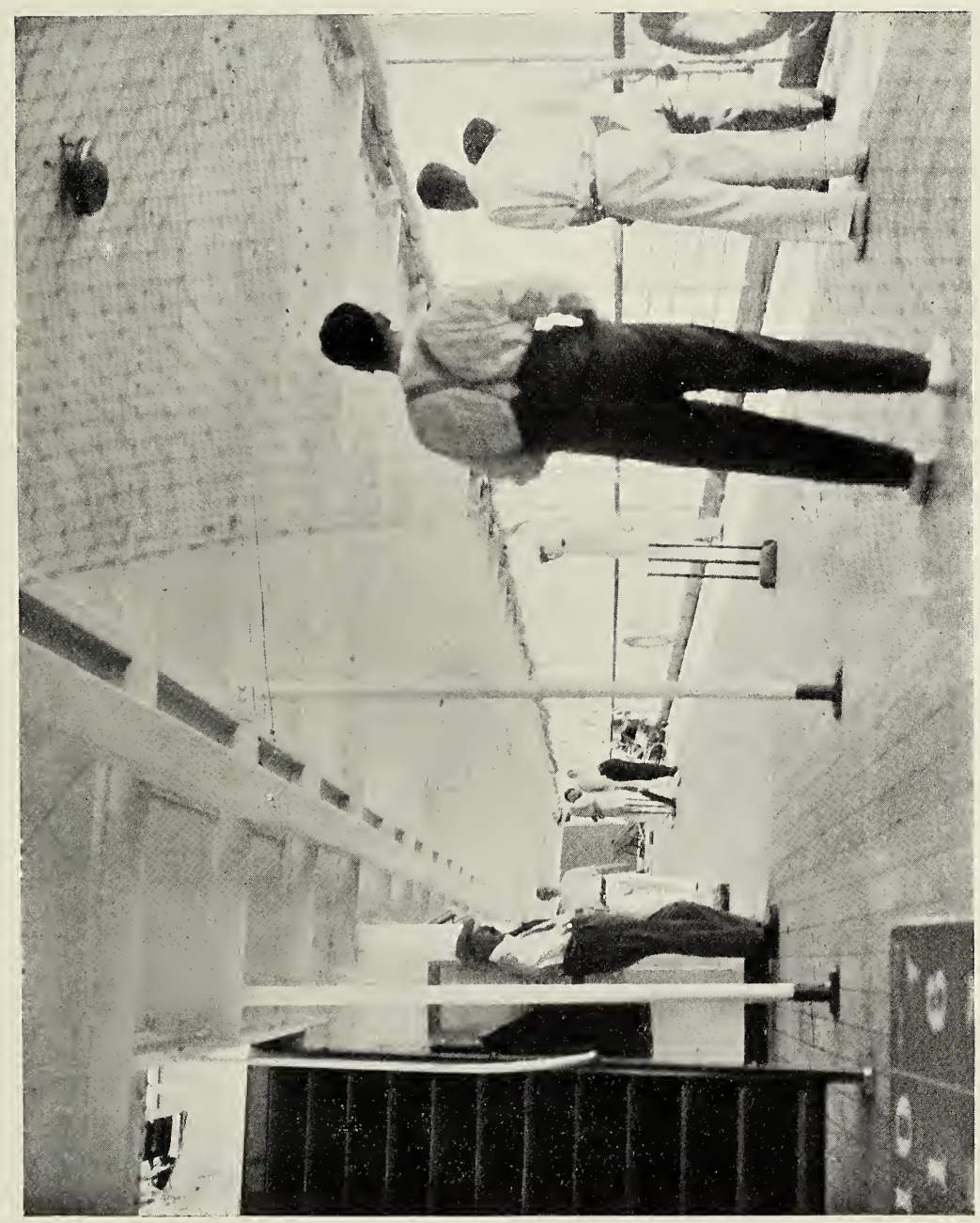



Diary of a Tour in South Africa. 2 I

she wept bitterly, and the last I saw of that scene was two men enveloped in the ample folds of her large embrace.

We had a peaceful start, the Solent being as calm as Southampton Water. At about 6.I5, just as it was getting dark, we put off the pilot at the Needles; and when we turned in for the night about I I o'clock, there was no perceptible movement of the ship.

\section{March I4, I5, I6.}

As these days at sea in fine weather are all more or less of the same pattern, it is useless to speak of them, except collectively. Suffice it to say we had an excellent passage across the Bay. We soon made the acquaintance of the Commander, Captain Brown, who had been specially asked by the Directorate of the Union Castle Line to look after our well-being; and we were quickly on very friendly terms, and quite at home in that very comfortable ship. 
22 Diary of a Tour in South Africa.

\section{March I 7.}

This morning we arrived at Madeira, and anchored off Funchal about 6 A.M. in fog and rain. The general appearance of things was somewhat similar to Gourock and the Clyde at its very worst, with nothing to be seen but mist and drizzle; so we decided not to go ashore, and spent the morning loafing about the deck watching some boys, of a very depraved looking type, dive for coins. Two young scoundrels, one quite an infant, climbed up the ship's side, right on to the boat deck, from which they dived, fully 40 feet, I imagine.

At I I A.m. we sailed for Cape Town, and shall probably not see land again for about a fortnight.

March I 8.

At I2 o'clock to-day we are 1,690 miles from Southampton, and our average run for the twenty-four hours appears to be anything 
SPORTS. 



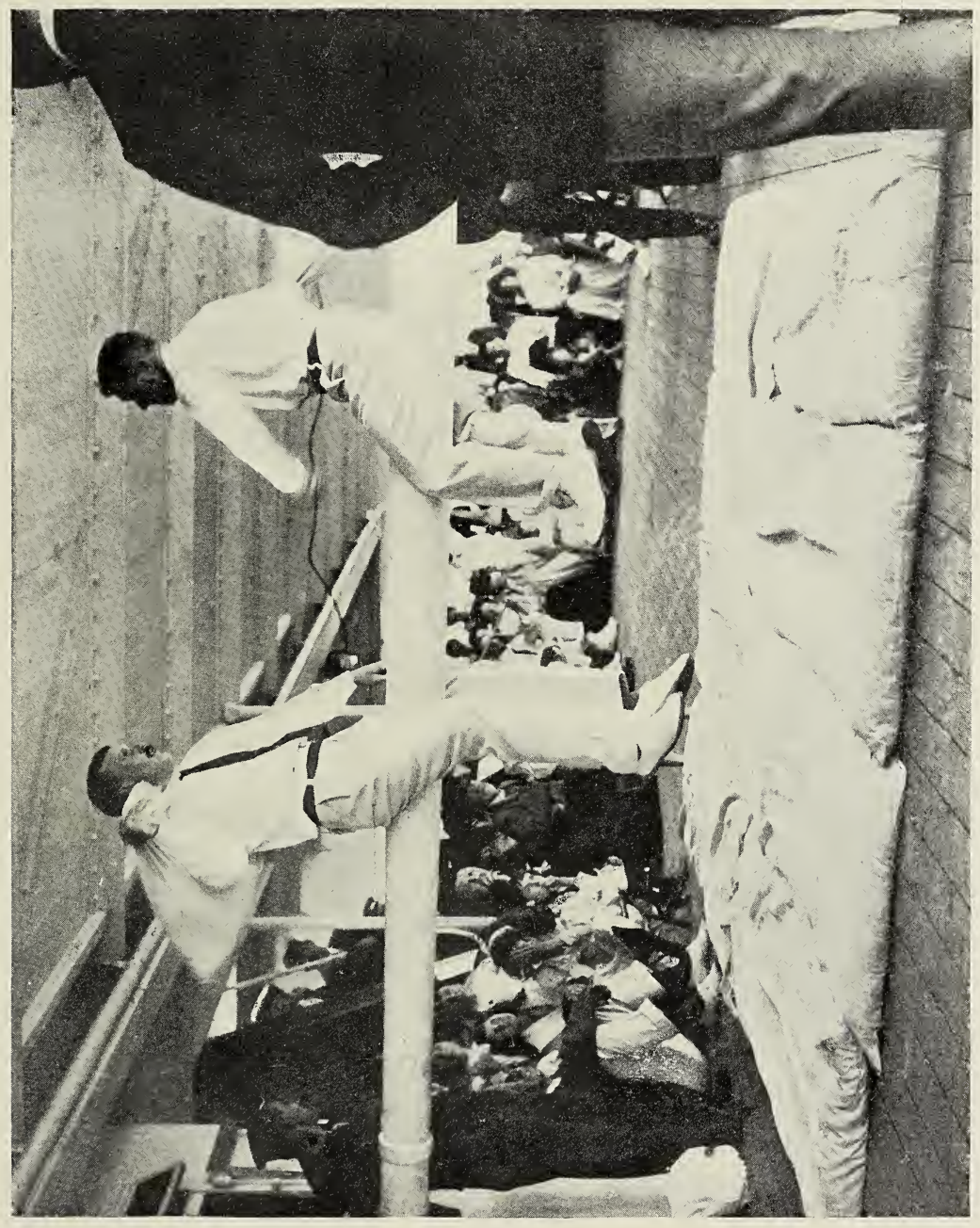



Diary of a Tour in South Africa. 23

from 360 to 380 miles. At last we have most beautiful weather, which is to be expected, as this evening we shall cross the Tropic of Cancer.

To-day we have seen a number of dolphins, and have also noticed flying-fish for the first time this voyage. Temperature in cabin still reasonable: last night, $67^{\circ}$, and this morning, $7 \mathrm{I}^{\circ}$.

We have on board some very well-known passengers, conspicuous amongst them being Sir Charles Metcalfe, the designer of the famous bridge over the Zambesi just below the Victoria Falls; a marvellous construction of most terrific height that must have been giddy work for those who built it. $\mathrm{He}$ is also consulting engineer to the railway which is slowly but none the less surely pushing its way to the north; and he is going out now in connection with another section, which will advance the railhead a further I 50 miles in the Cairo direction. There is, also, a very typical Excellency on board, going out to govern some 


\section{Diary of a Tour in South Africa.}

distant possession : the poor man looks as if he had been fed for some time past on a diet of cayenne pepper and whisky, and from all appearances his life does not promise to be a very joyous one in a hot climate. There is also a number of very nice young fellows going out to various posts in the Chartered Company, etc., and an entire absence of girls (not that this affected such a staid quartet as ourselves). There is, however, the usual "merry widow" going out to join her husband in Johannesburg; and several old maids.

With the above material on board, the few dances that were arranged after dinner were not very gay and giddy functions. I remember one evening, whilst the Professor and I were watching one in progress, that he sagely remarked to me: "Look here, old chap; some of these old girls are getting many a squeeze that they little dreamt of when they left their homes;" which very accurately summed up the situation. 
Diary of a Tour in South Africa. 25

March 19.

Passed Cape Blanco. Weather much hotter.

March 20.

Getting fearfully hot. $87^{\circ}$ in cabin.

March 21. Sunday.

Cold sea baths in the morning are now quite warm, sea temperature being $84^{\circ}$. I was told yesterday by our steward that this would probably be the hottest day, and it turned out to be so, although we don't cross the Equator till midnight to-morrow. The heat till about 4 P.M. has been perfectly appalling. Then a thunderstorm came on, and it became much cooler. They say that the great heat of this part is caused by a hot stream coming out of the Gulf of Guinea, striking out into the ocean at this point. We stayed up in the bow till near midnight watching the incessant play of the lightning round fully half the horizon. It was 
26 Diary of a Tour in South Africa.

truly a magnificent display, and the like of it I never expect to see again.

March 22.

We have got into the south-east Trades, so it is not nearly so hot to-day.

We saw great numbers of a species of nautilus, whose pink sails looked very beautiful in the bright sunlight, but they evidently don't approve of this change of wind driving them to the north, and have all gone below. I know very little about these creatures, but I believe their power of flotation is derived from a chamber contained in their shells, which they are able to fill with either a kind of gas when they desire to float, and with water when they want to go below.

\section{March 23.}

There have been two functions to-day. First, crossing the Equator, which did not come off till 6 A.m. Then, in the evening, we celebrated the Laird's birthday by asking the Captain to 
Diary of a Tour in South Africa. 27

dine with us; and all the other officers took part in the proceedings, through the medium of champagne, which had been ordered by our hosts for their mess. After dinner, we adjourned to the Captain's room on the bridge for bridge, where we spent a very pleasant evening; and, in returning to our cabins, got a good view of the Southern Cross for the first time, although it had been visible for several nights past low down in the sky.

March 24, 25, 26.

Nothing of note, except weather getting gradually cooler, and during the last couple of days there have been sports on deck.

\section{March 27.}

Sea rough, and getting worse.

March 28. Sunday.

We have been to Service this morning, but the congregation was small, as there is a rough sea on, much the roughest we have had. 
28 Diary of a Tour in South Africa.

March 29.

Heavy swell all day.

March 30.

We arrived at Cape Town (5,987 miles from Southampton) at dawn, and, as at Madeira, found it very wet and foggy. We got ashore about 9 o'clock, and after a little fuss in the Custom House, drove to Mount Nelson Hotel. Breakfast ashore again was quite an agreeable change. The rain cleared off about midday, and in the afternoon we had a very interesting drive by the Kloof to Camp's Bay, a favourite resort in summer of the Cape Town people.

We managed to have another birthday party that night-my own; and so ended our first day in South Africa.

March $3 \mathrm{I}$.

To-day we have had a most glorious drive completely round Table Mountain (35 miles), 


\section{DRIVE ROUND TABLE MOUNTAIN.}




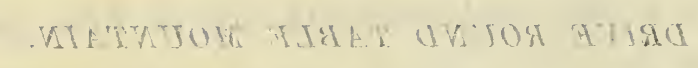



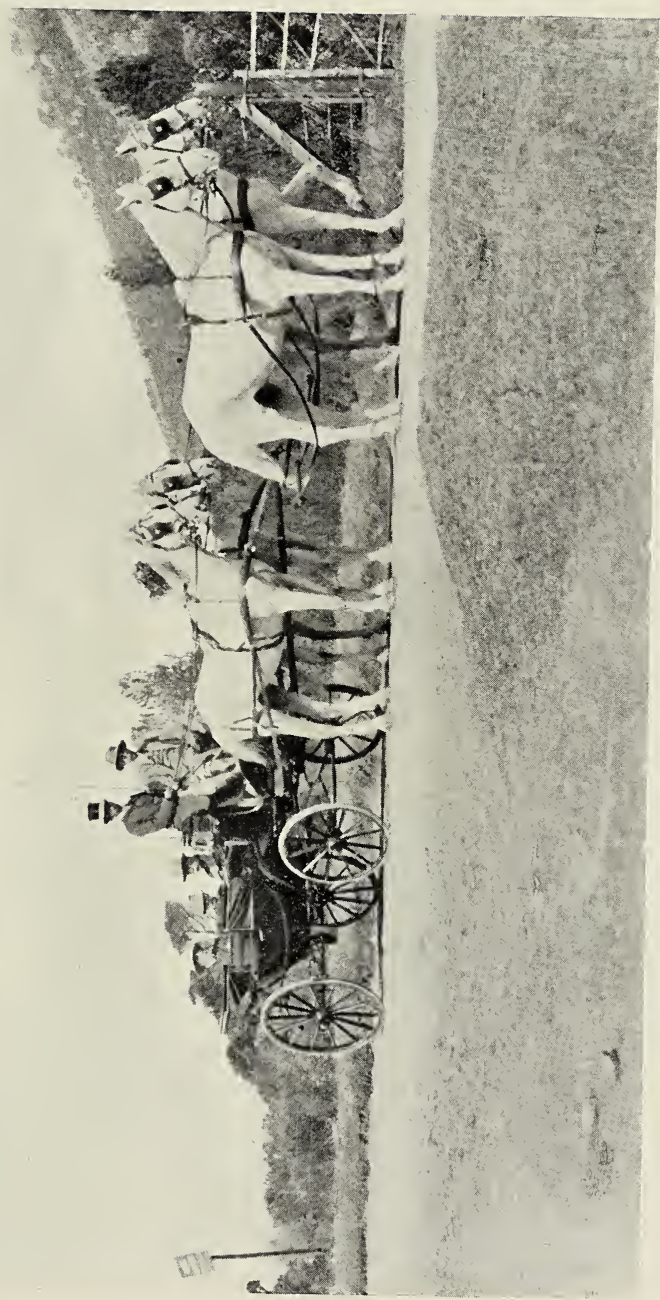

PEAKS OF "THE TWELVE APOSTLES." 


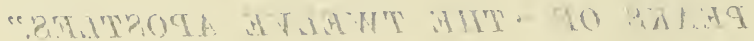




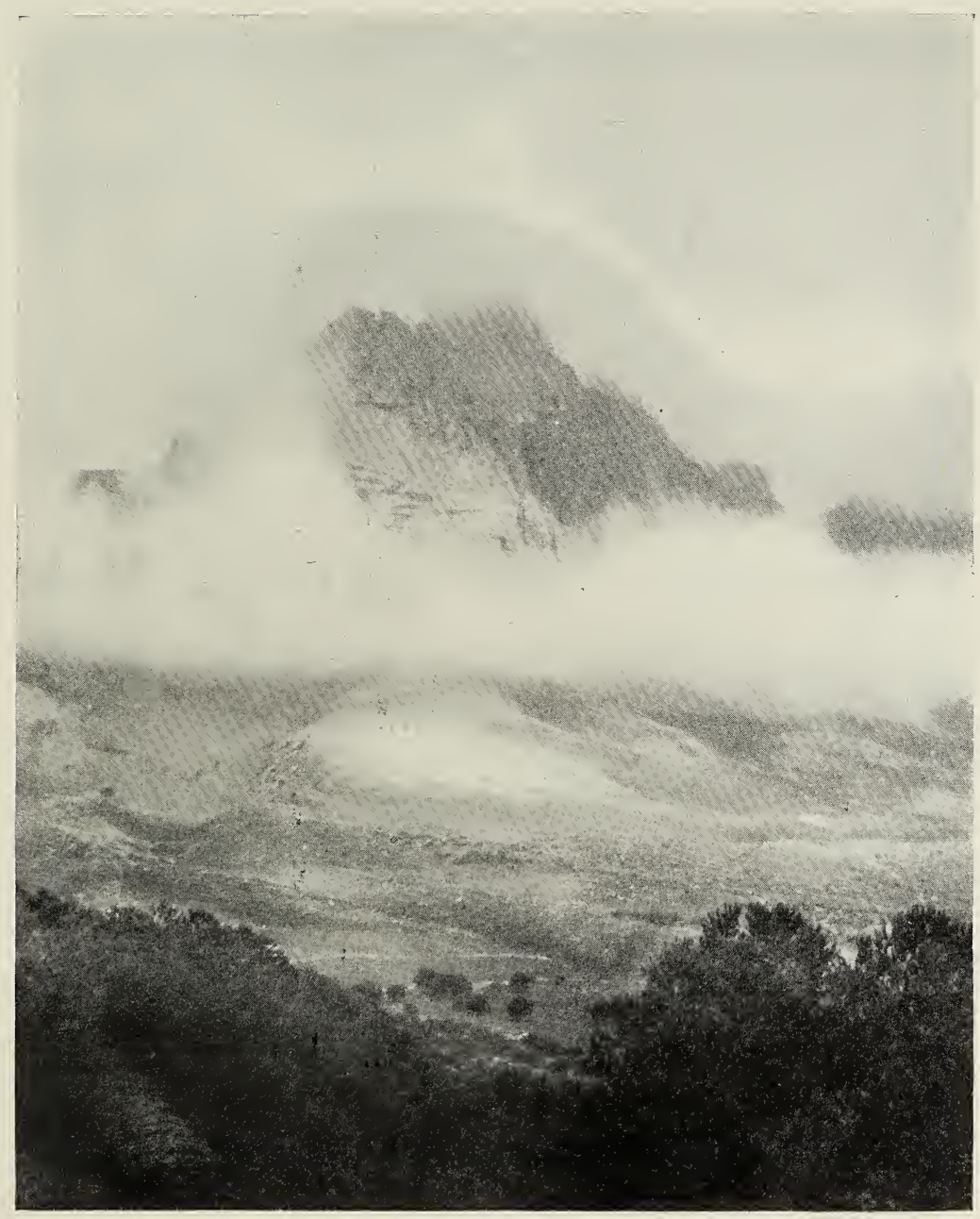



Diary of a Tour in South Africa. 29

in a comfortable landau drawn by four good horses, driven by a Malay coachman (most of the Cape Town jehus appear to be Malays). We passed through a number of interesting places: Rodebosch, where is situated one of the estates of the late Cecil Rhodes and his house Groote Schuur. The road then passes through Wynberg, at which place is the Military Camp and Hospital; thence to Constantia, which produces the best wine in the Colony; and then on to Hout's Bay, a deep inlet on the Atlantic side of the peninsula, which from some points looks quite land-locked. The coast road is then followed along the foot of the mountains known as "The Twelve Apostles," through Camp's Bay and Sea Point, back to our comfortable quarters at the Mount Nelson Hotel, where during the evening Mr. and Mrs. Andrew Coats and their two daughters called on our hosts, and we (that is, the "Professor" and I) also made their acquaintance; and soon after 
30 Diary of a Tour in South Africa.

learned that they were to be of our party when we return to Europe, in about three months' time. After the Coats family had departed, Mr. Dan and I settled down to a South African time-table, with the amiable intention of mapping out our coming Tour. All I can say is that that time-table nearly did for me, and was a most astonishing revelation to anyone accustomed to the railway facilities at home. Well, our first objective was Oudtshoorn, 9 Io miles by rail from Cape Town, and about 200 miles in a straight line. Now, the aforesaid marvellous time-table revealed to us that, if we left Cape Town at I I.30 A.m. on Saturday, April 3 rd, we should reach Oudtshoorn on Wednesday, April 7 th, at 3.40 P.M. The same celebrated work also revealed to us that if we didn't leave this abode of the ostrich the next morning (Thursday), we conldn't leave till 9.30 A.M. on Sunday, the IIth.

At this stage I began to wonder whether we 
had had too many birthday parties, or if my brain was giving way; at any rate, we decided we must be "all wrong," and we'd go and ask Thomas Cook next morning; which we did, and found to our amazement that we were "all right," and the above was actually our timetable on the first stretch of our journey!

\section{April I.}

This morning, after first verifying the above queer specimen of railway travelling-queer to us then, but destined in a few weeks to be quite a natural proceeding, such is the adaptability of human nature-we heard that our future home on wheels had arrived from Vryburg (774 miles from Cape Town), from which place the line to the north is worked by the Rhodesia Railways, Ltd., the private car engaged by our hosts being the property of this company. It was no easy matter to find the said car, all we knew about it being that it 
32 Diary of a Tour in South Africa.

was somewhere in the goods yard, an enormous enclosure. However, by dint of searching, we at last found it, and also found that we could do no more than gaze at it from the outside, as the doors were locked and the blinds all down, which was a disappointment to us all. The only observation I could make was that it was the longest car I had ever seen. The rest of the day was spent at various shops adding to our store of creature comforts for the journey, and arranging that we should start on Saturday, the 3 rd.

\section{April 2.}

This, our last day in Cape Town for the present, has been mainly occupied in making additional purchases, and, by myself, in being initiated into the intricacies of the manner of levying South African customs.

It is now, since the new Act of Union, a simple matter; but as our visit took place 
THE DEVIL'S PEAK, CAPE TOWN. 



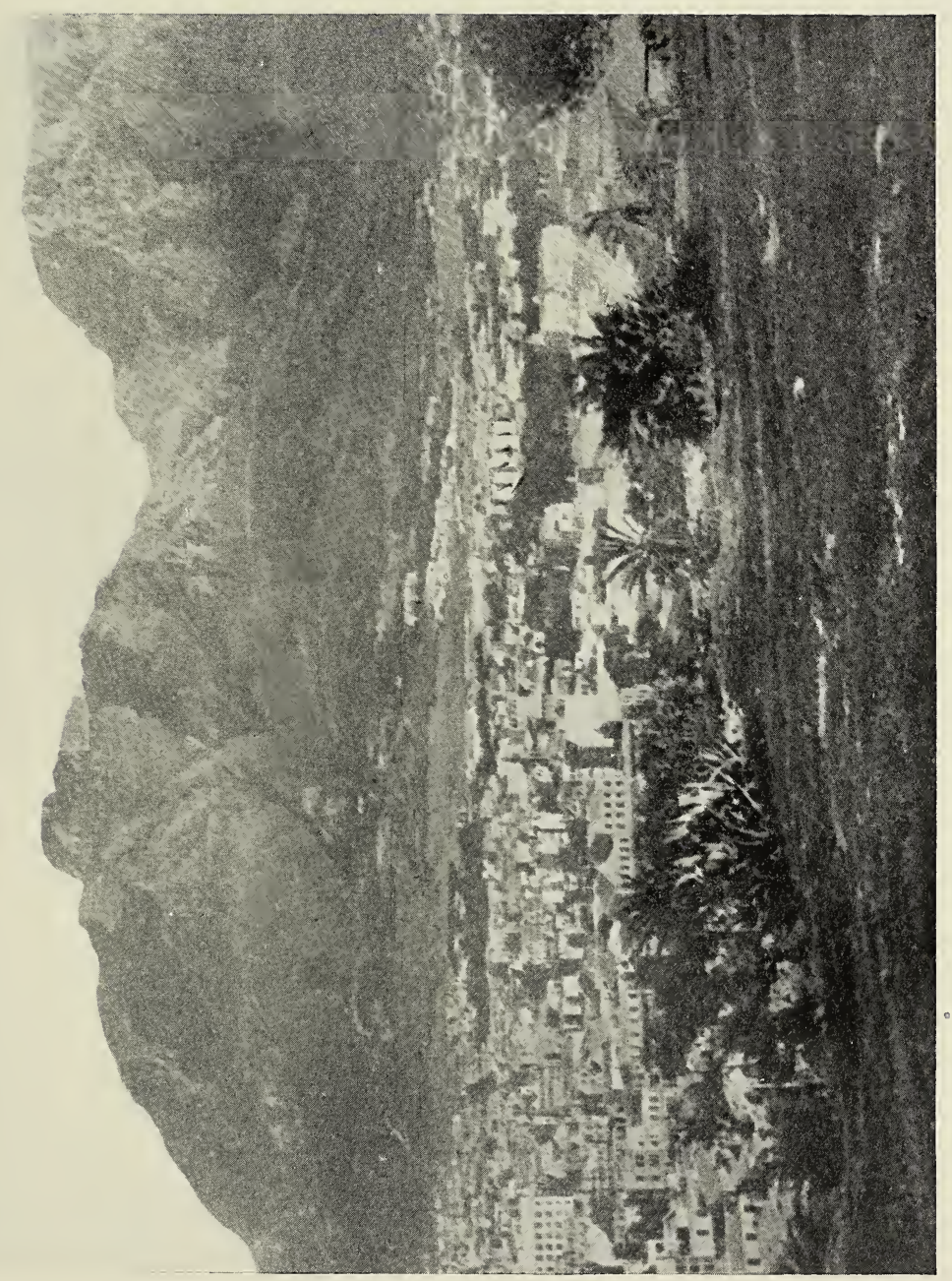



Diary of a Tour in South Africa. 33

a few months prior to the passing of this Act, we came in for all the old inconveniences. I mention this matter, as I was deputed by my hosts to look after this matter of customs in so far as it related to the contents of our car, which was choke full of dutiable stores.

Roughly speaking, the method in vogue was as follows :-

The port of entry collected the entire duty on any goods coming in, and then kept 5 per cent. of the duty, paying over the balance to the Colony to which the goods were consigned. This, of course, worked out quite easily in the way of ordinary merchandize; but with ourselves, carrying a cargo of dutiable stuff into a Colony and leaving it again in three days, as we did in the Orange River Colony, it became a most objectionable nuisance, as we had to get entirely new lists made out of the contents of the car before we could proceed into Natal, and so on. 
34 Diaky of a Tour in South Africa.

I should mention in passing that we were never boarded by any customs official in passing from one Colony to another, which, after one or two frontiers had been passed, rather impressed one with the idea that we were having a lot of trouble for nothing. But unless these papers had been kept in order right through and back to Cape Town, no rebate would have been paid by the Cape Government on the arms and surplus stores we brought back to this country; and I understand that in this connection the above Government had eventually to refund well on to $£$ ioo in the way of rebate.

This diary is no place to discuss the question of tariffs; but I was much impressed with the lack of reciprocity shewn by our country to its Colonies, as demonstrated by the stores of various kinds which we took out with us, all of which that could be shewn to be of British manufacture going in subject to a preferential 
Diary of a Tour in South Africa. 35

tariff, while the goods we had with us made in Germany, Austria, America, etc., paid a higher rate. The opposite side to this picture being that the Cape wines, etc., bought by our hosts would be subject, on their arrival here, to exactly the same duties as the wines of France and Germany - a one-sided, antiquated arrangement that, I understand, Cape Colony is getting sick of, and will probably abolish, if the out-of-date tariff system of the Mother Country is not soon reformed.

April 3.

At I I.3O this morning we started on what is a journey over practically the whole of the railway systems of South Africa in the car provided by the Rhodesian Railway Coy., the arrangement being that we could be attached to any train, passenger or goods, on any of the railway systems in the country. At this point a short description of the car is necessary. 
36 Diary of a Tour in South Africa.

At one end was a very comfortable diningroom taking the whole width of the car, intended to accommodate six persons, but really only comfortable for our four selves. Then a corridor ran right along on one side as far as the kitchen and servants' quarters, which were shut off by a door from ours, but this door we soon found was not proof against kitchen odours. Our bedrooms opened off the corridor, of which we had two with two berths each and one with four berths. The Laird and Mr. Dan had each a two-berth room; the Professor and I were quartered in the four-berth room; and in each case we used the top berths for our luggage, which enabled us to keep our goods and chattels in the car during the whole journey. The rest of the car was entirely taken up with general stores, of which we had great quantities.

In addition, there was an observation platform outside the dining-room, store-room, 
TABLE MOUNTAIN AND CAPE TOWN. 



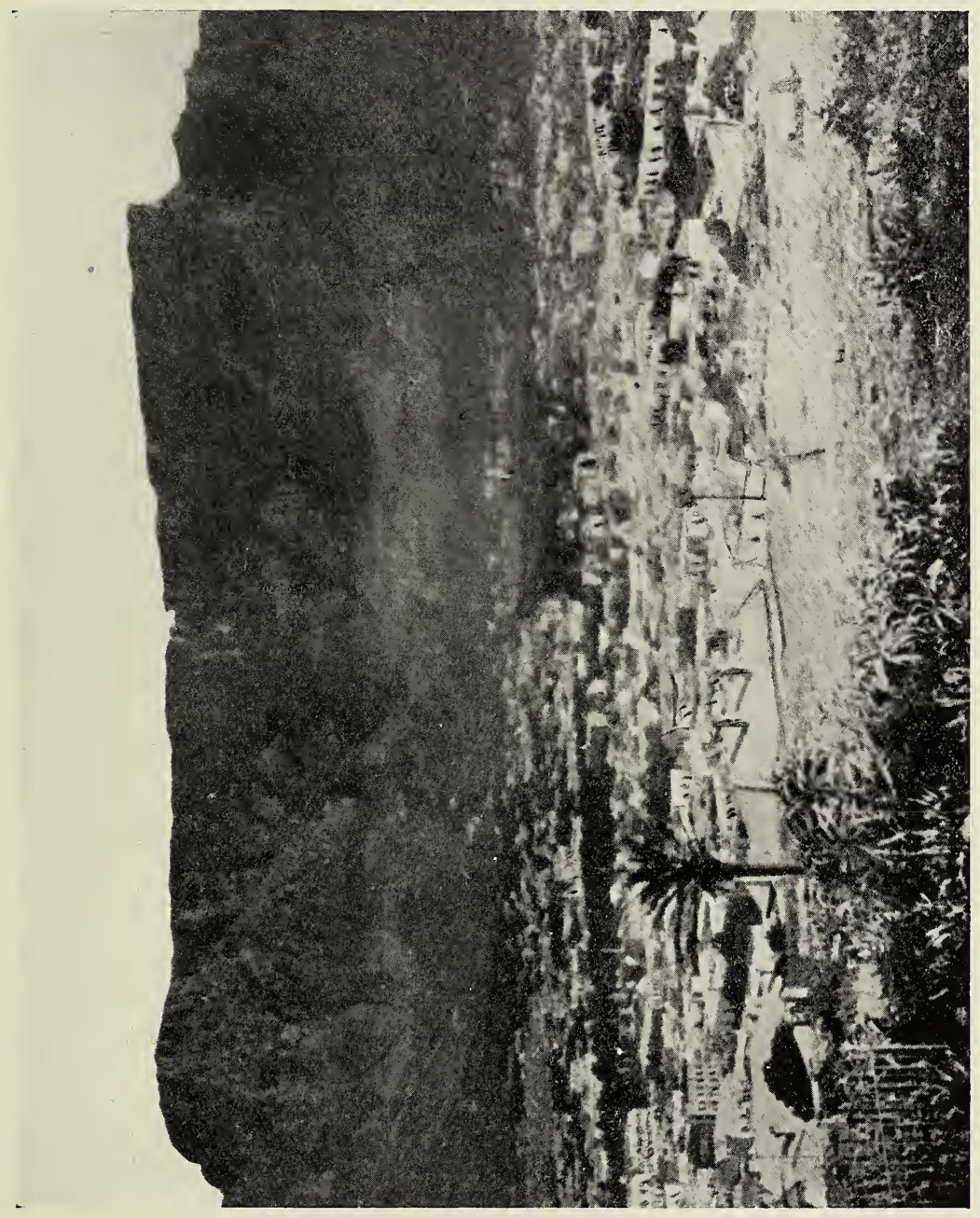



THE CAR STAFF AND THE WHIPPER-IN. 
. MT- 


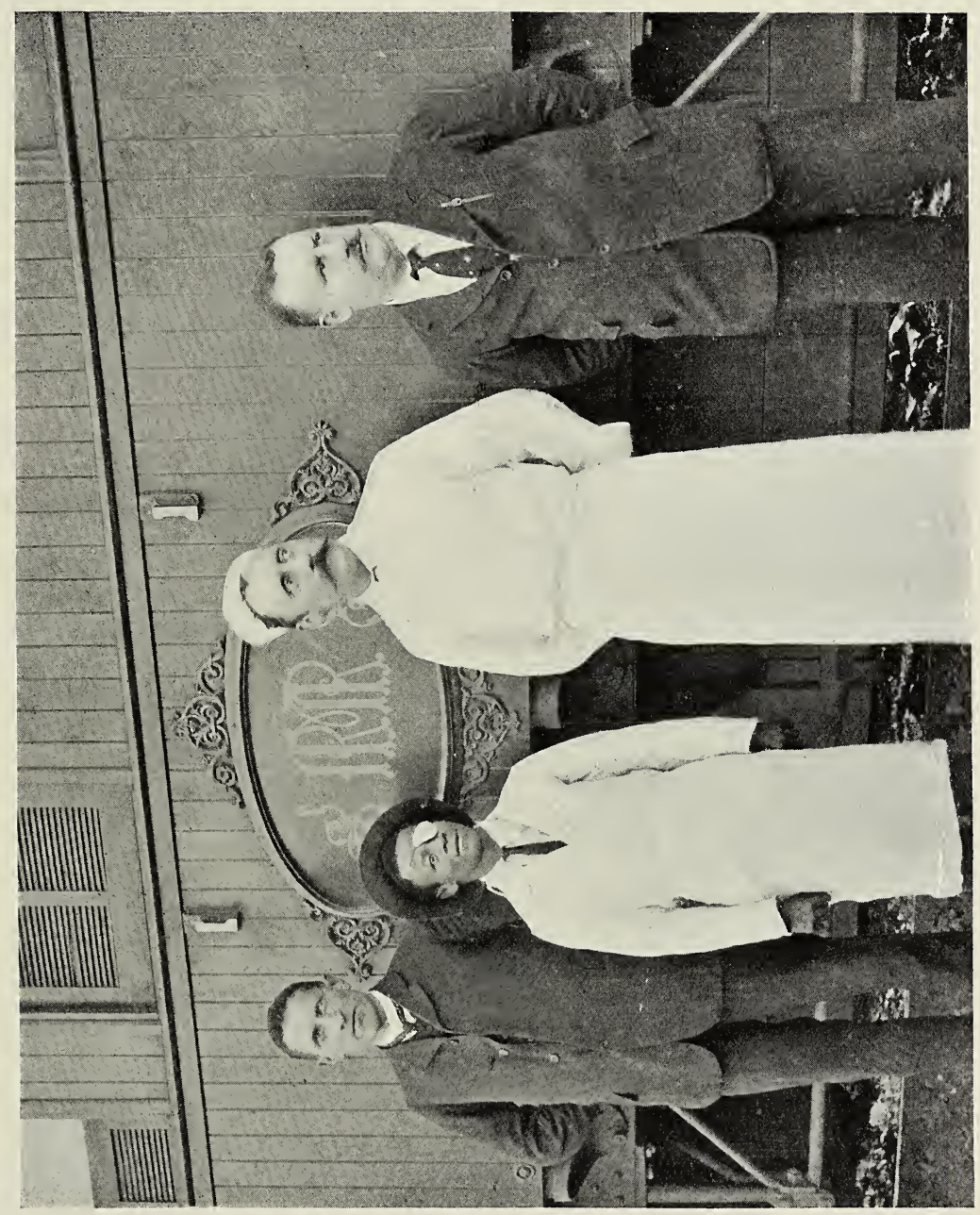



Diary of a Tour in South Africa. 37

lavatories, bath-room, and water tanks on the top and also underneath. Besides which there was a dynamo and accumulators underneath car for the supply of electric light, enough of which we could store to last us about three days when the car was at rest.

The staff consisted of a French chef, a goodlooking fellow, with a big scar on his face, who had at one time served in the Chasseurs d'Afrique; Clark, a sort of combination of waiter and general food forager, fairly often "on the spree"; and the inevitable Kaffir "boy," of whom more later.

Added to the above was the Laird's man, the admirable Guntrip (whipper-in to the above worthies), whose kind services to us all will not easily be forgotten.

'Twas a showery morning as we steamed out of Cape Town, and there were heavy rain-clouds about the hilltops, quite of the Scotch pattern; and we prayed they might 
not mar the scenery of the Hex River Pass, which we expected to see ere dusk. However, by the time we had reached Worcester (Io9 miles), the weather had improved, and we had good views of the Hex River valley and mountains, which form the buttress of the Great Karoo Table Land, and which looked impossible for anything but a cog-wheel railway.

However, up we went, with a powerful engine at each end of the train, by means of steep gradients and sharp curves, a rise of 2,400 feet in 36 miles, 20 miles of which consist of gradients of $\mathrm{I}$ in 40 and $\mathrm{I}$ in 45 . By the time we reached Touws River, where the rear engine was taken off, it was dark, and it was 9.45 P.M. when we arrived at Matjesfontein $(2,970 \mathrm{ft})$, I 94 miles from Cape Town, where our car was detached for the night, the train going on to the north. 
Diary of a Tour in South Africa. 39

April 4. At Matjesfontein.

We are spending this Sunday here, certainly not on account of the natural beauties of the place, but one might say because it is the least objectionable on the line through the Great Karoo in which to put in time, and we have got to put in time somewhere, as the train from De Aar Junction does not leave for Oudtshoorn till midnight on Monday. We began the day with a late breakfast, after which we sauntered over a stretch of the Karoo for about an hour, and found it a very thirsty spot. Although the time of year corresponds to our October, and we are, at this place, at about the same altitude as the top of Ben Lomond, the heat and the glare were very trying at any time between 9 A.M. and 4 or 5 o'clock in the afternoon.

The Great Karoo is difficult to describe. It extends for a distance of about 350 miles east 
40 Diary of a Tour in South Africa.

to west, at a level varying from 2,000 to 3,000 feet above sea-level. It is really a desert without sand, covered with a low kind of bush, and dotted with low ironstone hills, or koppies, as they are called. The soil is said to be fertile, but there is an entire absence of cultivation, except where the possession of capital has enabled the farmers to construct dams for the storage of water. The total area is said to exceed I00,000 square miles. After the heat of the day we found the night very cold.

Returning from our morning walk, we encountered the renowned Jamie Logan, the "Laird" of the district, who took us into his very comfortable house, gave us drinks, and told us stories of the war. In the afternoon he very kindly lent us two Cape carts (our first experience of them), in which we were driven about five miles across the Karoo to see the grave and monument of General Wauchope, who was killed at Magersfontein. We thought 
THE HEX RIVER PASS. 


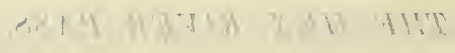




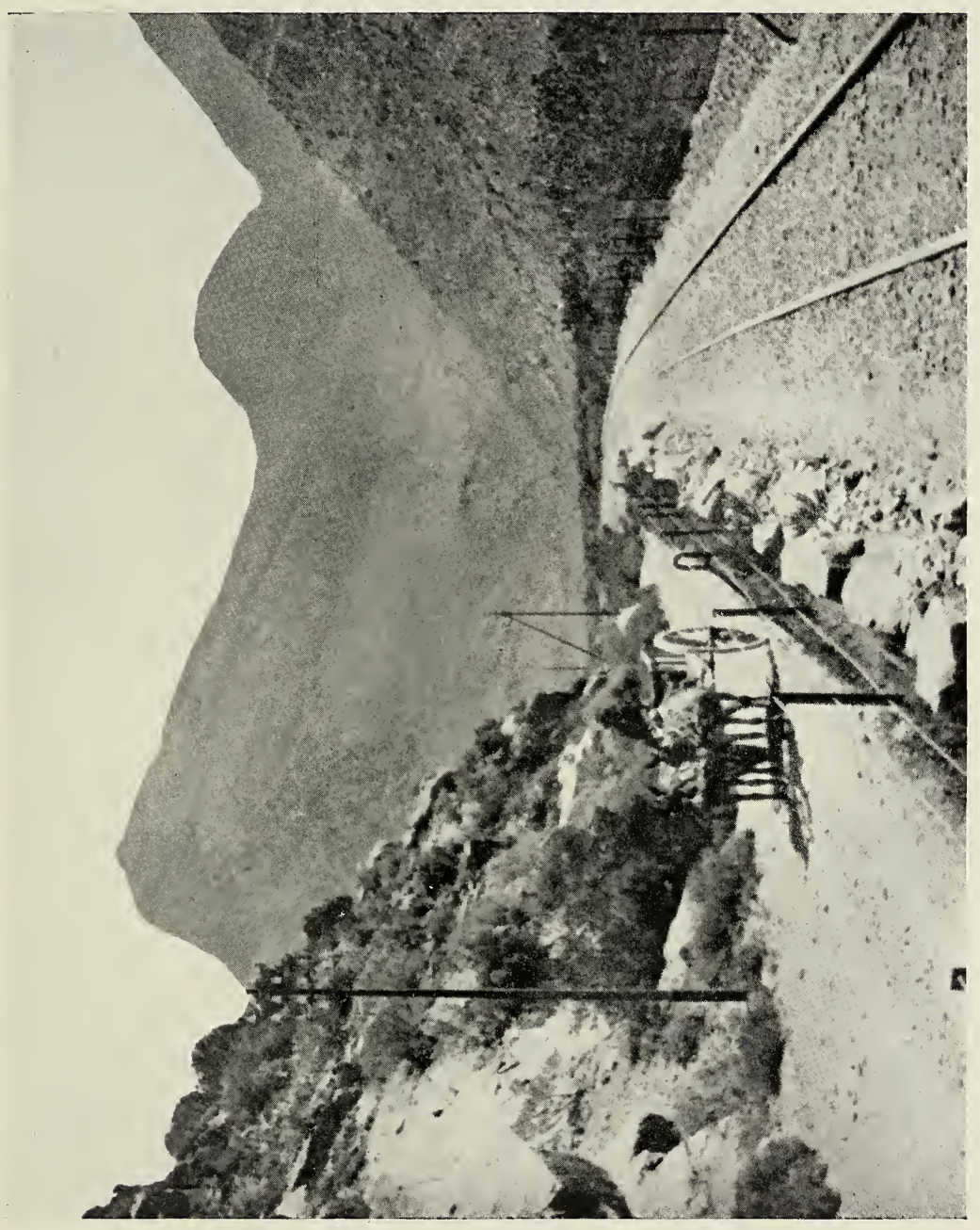



Diary of a Tour in South Africa. $4 \mathrm{I}$

it rather a rough drive, as there was not much pretence of a road, but it was excellent compared with some of our drives later on.

\section{April 5.}

We left Matjesfontein at 7 A.M., and have certainly made a thorough acquaintance of the Great Karoo, having travelled all day across it. During the day we have seen several swarms of locusts, probably a mile or two in length. The coming of the swarm was in each case heralded by a number of the insects flying very high, which in the glare of the sun looked like a lot of small white birds; but when the mass of the swarm passed between us and the sun, it was exactly like the passing of a blackish cloud. We also saw a number of ostriches prowling about.

At mid-day we had a little excitement, being suddenly, for a few moments, enveloped in the most dense clouds of dust. It transpired that 
42 Diary of a Tour in South Africa.

the engine tender had left the rails, but, fortunately, after a few seconds, the engine pulled it on to the rails again, else we might have had more of the Great Karoo than we had contracted for; and I think anyhow by this time of day, we had all begun to feel we'd had about enough of it, and would not have been displeased to rest our tired eyes on something green again.

The temperature has been $75^{\circ}$ all day in the car. We reached De Aar Juuction (4,079 ft.), 500 miles from Cape Town, at IO P.M., at which place we left the main line to the north, and are now, as I write, at I 2 P.M., on the Port Elizabeth line, and are going, via Nauuwpoort Junction, to Rosmead Junction.

April 6.

This has been a most interesting day. About breakfast-time we came over the Lootsberg Pass $(5,727 \mathrm{ft}$.), the highest point reached on 
Diary of a Tour in South Africa. 43

the railways of Cape Colony, the steepest gradients being $\mathrm{I}$ in $3 \mathrm{O}$, and the curves of a most formidable nature. It was in coming over these mountains that we seemed to be passing a train, and discovered that it was only the rear portion of our own. I may here mention that all the main trunk routes in South Africa consist only of a single line of rails, the gauge being $3 \mathrm{ft}$. 6 in.

In the districts we passed through, the ostrich is as numerous in the fields as sheep in Sussex. During the day we saw many swarms of locusts, this being a much infested district; and we passed right through a very dense swarm, which beat on the train like hailstones, and battered against the camera I was using. The train stopping during the passing of the swarm, we could see that the ground also was completely covered with them. Occasionally trains ascending gradients are held up by swarms, myriads of the insects being crushed 


\section{Diary of a Tour in South Africa.}

by the wheels, rendering the rails so slippery that it is impossible for the train to proceed. We rather regretted it did not happen in our case, as we had a great desire to view the creatures at close quarters, and the momentary stoppage of the train did not allow us to alight. Although they will eat every blade of grass and all the leaves from the trees, fortunately they will not touch the lucerne, which is the main food of the ostrich, unless they are in a starved condition; but, I understand, it is poisonous to the insect, for which, no doubt, the ostrich farmer is duly thankful.

At 3 P.M. the temperature was $83^{\circ}$ in the car, it having been much the same all day. We reached Graaff-Reinet (2,463 ft.), 694 miles from Cape Town, at one o'clock, and, after lunch, we strolled into the town, which seemed to consist mainly of one long street.

Graaff-Reinet is beautifully situated and has a prosperous appearance. The district is 
Diary of a Tour in South Africa. 45

famous for the angora-goat industry, and there are numerous ostrich farms and large numbers of orchards and vineyards, the finest grapes and fruit generally produced in the Colony coming from this district. The place is a veritable oasis in the Karoo, thanks to abundance of water obtained from the Sunday River. We left at 7.25 P.M. during a heavy thunderstorm and downpour of rain; violent and frequent thunder-storms being rather a feature of this district.

April 7.

Oudtshoorn, I,O 4 feet, 9 Io miles from Cape Town.-We arrived here at 3.40 P.M., the journey all the day having been most interesting. During the morning we passed through the celebrated Toverwater Poort, a most magnificent narrow gorge, about two and a half miles in length, through which the train follows the windings of the river, the bed of which is 
quite Scotch in character, but not so the lofty, bare, precipitous rocks rising to a great height on either side, so high that any direct sunlight was shut out, and a few good photographs rendered impossible from a moving train. As we start early to-morrow for our trip to the Cango Caves, we decided to go early to bed, but this did not come off, as just as we were going to turn in for the night an unearthly din was started quite close to our car.

A circus had arrived that day, and the din was caused by the arrival of the circus proprietor's wife from the town, bringing with her two big elephants and about a dozen blacks, to fetch a huge caravan, probably the lady's sleeping quarters, as the windows were adorned with muslin curtains. We came in for the full blast of the operations, as the huge concern was resting on two trucks on the rails alongside our car. The "lady," a masterful-looking creature of about forty, adorned with a gay 
Monte Carlo hat, sat on a tub and issued her orders, and she did make those niggers jump about. The night was as black as ink, and the whole scene was lit up by the white light of three very rudimentary acetelyne gas jets, the reservoirs of two of which continually created a diversion by going on fire. It was really a weird scene. The two huge elephants, looking probably bigger than they really were in the white artificial light giving very deep shadows ; the scrambling niggers, and the swearing, cursing, over-dressed lady on the tub, were a sight one does not easily forget, or see for the second time. During the operations, a subsidiary diversion took place which created a big ruction. One of the elephants, tired of waiting about while the niggers jacked up the caravan for the purpose of putting on its wheels, wandered off and got into some one's kitchen garden, where it stuffed itself with cabbages and other delicate morsels, before it was discovered. 
48 Diary of a Tour in South Africa.

However, eventually elephants, caravan, niggers, and lady all departed for the town, peace reigned over all, and we slept.

April 8.

We were up at six this morning, and started at eight in two Cape carts for the Cango Caves, which are situated at the base of the $Z$ waartberg Range, nineteen miles distant from this place. Unfortunately this trip is marred by the absence through illness of our genial medical adviser, who so far has kept us all in goodgoing order, but has not been so successful with himself. I am thankful to say he is much better this morning, having considerably less fever than the last day or two; but he, we all think wisely decided, that thirty-eight miles' jolting in a Cape cart was not exactly the thing for him this hot day.

The country all round about Oudtshoorn is very picturesque, more especially the road 
ENTRANCE TO THE CANGO CAVES. 



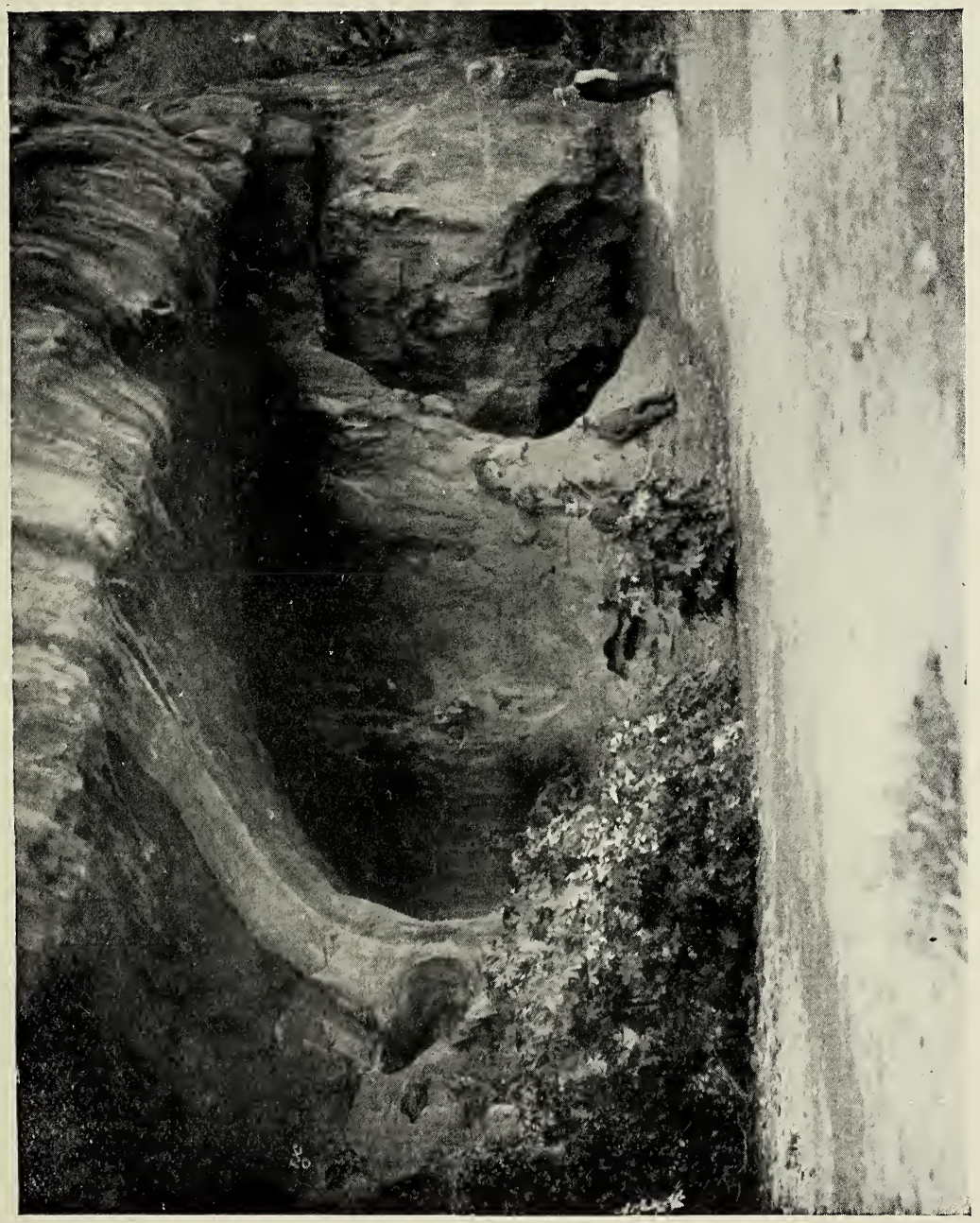



Diary of a Tour in South Africa. 49

which leads over the $Z$ waartberg, following as it does the windings of the Grobbelaar River; and that morning's drive will always remain a most charming recollection, full as it was of endless variety. In addition to the really magnificent scenery, there were fields of tobacco, ostrich camps, as they call them, in great numbers, and large baboons scrambling up the hillsides, some of them as big as small men, and of which there is said to be a great number in these mountains. At II.3O we reached our destination, and had lunch by the side of a good-sized stream, under the pleasant shade of a beautiful tree of the weeping-willow variety. That lunch will long linger in my memory, not by reason of the grey peaks of the $Z$ waartberg Range towering in their grandeur round about us, or on account of the bright, beautiful stream at our feet, racing down from the mountains to join the Grobbelaar River in its windings through that glorious 
50 Diary of a Tour in South Africa.

valley: but because it was my first encounter with a "mutton chop" of the South African variety. Those mutton chops had been much vaunted by the landlord of the hotel at Oudtshoorn, under whose auspices we were making this Cango Caves trip. He had seemed quite inspired the previous evening, when he suggested these delicate morsels, and that they should be cooked on the spot on a grill over a wood fire, by his two Kaffir jehus. Doubtless a seven o'clock breakfast, followed by a drive of nineteen miles amongst the hills at an altitude of a couple of thousand feet does promote a good healthy appetite, and I frankly confess that as the morning progressed the glamour of those mutton chops began to fill my soul with impatience.

On our arrival at this charming spot, we must all have felt healthily hungry, as, though only about eleven o'clock, it was decided we should lunch at once. The grill soon started 
ON THE WAY TO THE CANGO CAVES. 


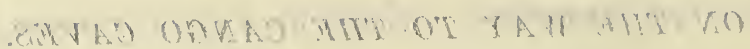




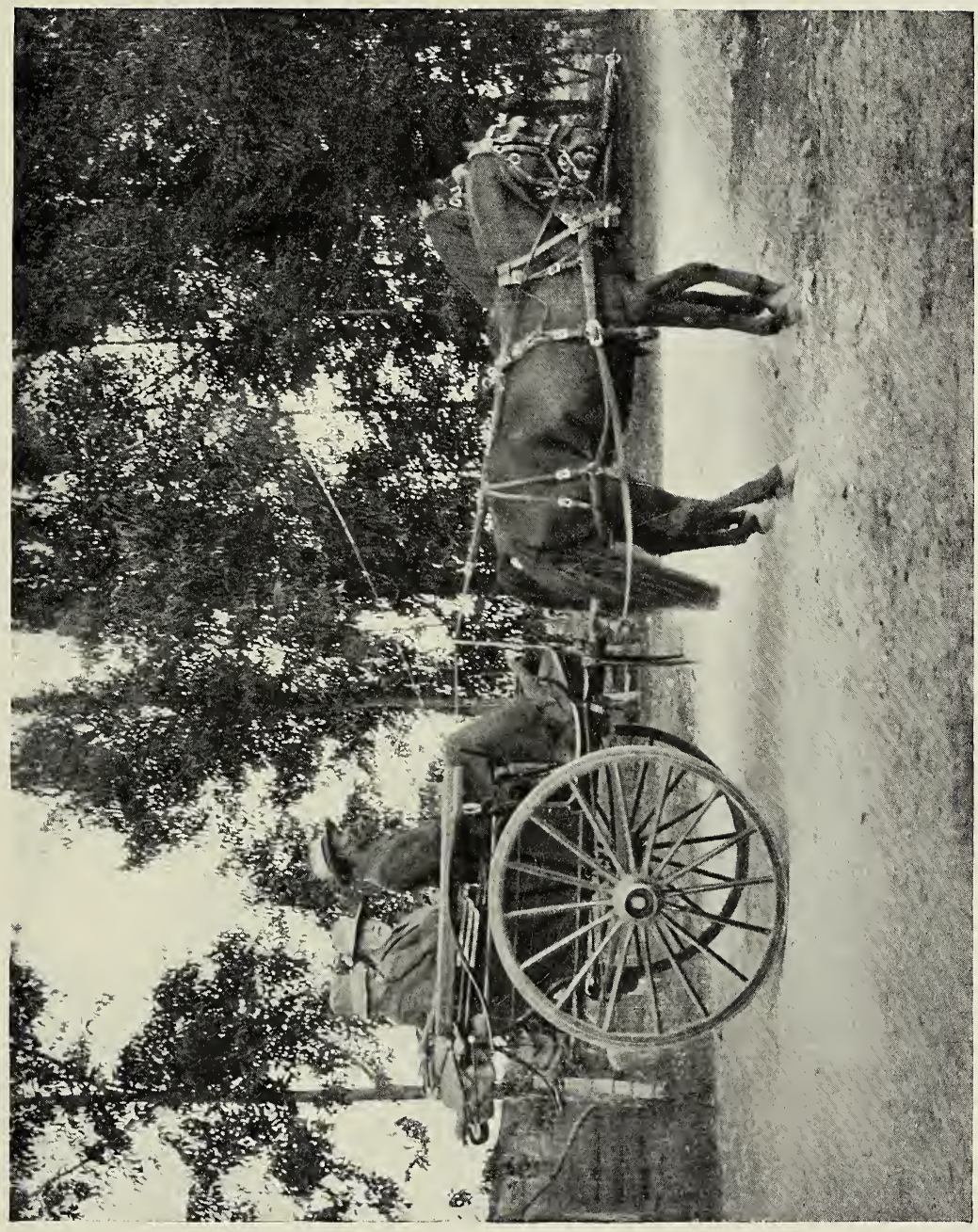



operations, and the whole scene, both from a photographic and olfactory standpoint, became exceedingly interesting and satisfactory;-now I am face to face with the material result, and know the "Thing" that is possible to masquerade in South Africa under the homely name of a grilled mutton chop. I have tried to get at that chop from all points of the compass. I did manage to find a vulnerable spot in which I was able to insert the prongs of a fork, but the knife which pretended to have come from Sheffield (probably via Germany), steadfastly refused to make the slightest impression upon it, and after worrying the Thing quite uselessly for some time, I came to the conclusion, that its ancestors on both sides had been goats, and that nothing but the fangs of an able-bodied and energetic baboon or jackal, could possibly make any impression upon it; and that probably was its fate later on when we had vacated the spot, and the shades of 
52 Diary of a Tour in South Africa.

evening had begun to fall. Fortunately we had plenty of good bread, butter, and cheese, so we did very well on the whole; but I shall never forget my encounter with that pièce de resistance.

After lunch, with the day at its very hottest, we toiled up the hillside for about a mile to the entrance to the Caves, which are said to be some of the finest stalactite caverns in the world. They were discovered by a Boer when hunting in 1780 , and after having been subjected to attacks of vandalism for many years, have recently been taken charge of by the Cape Government. The Caves consist of many large and small chambers, and have been explored for over a mile, but are said to be of much greater extent. The deposits of the lime-impregnated water have assumed every imaginable shape, and where the suspended stalactite has met the stalagmite beneath, huge pillars have been formed, in many 
KAFFIR COOKS AT THE CAVES. 



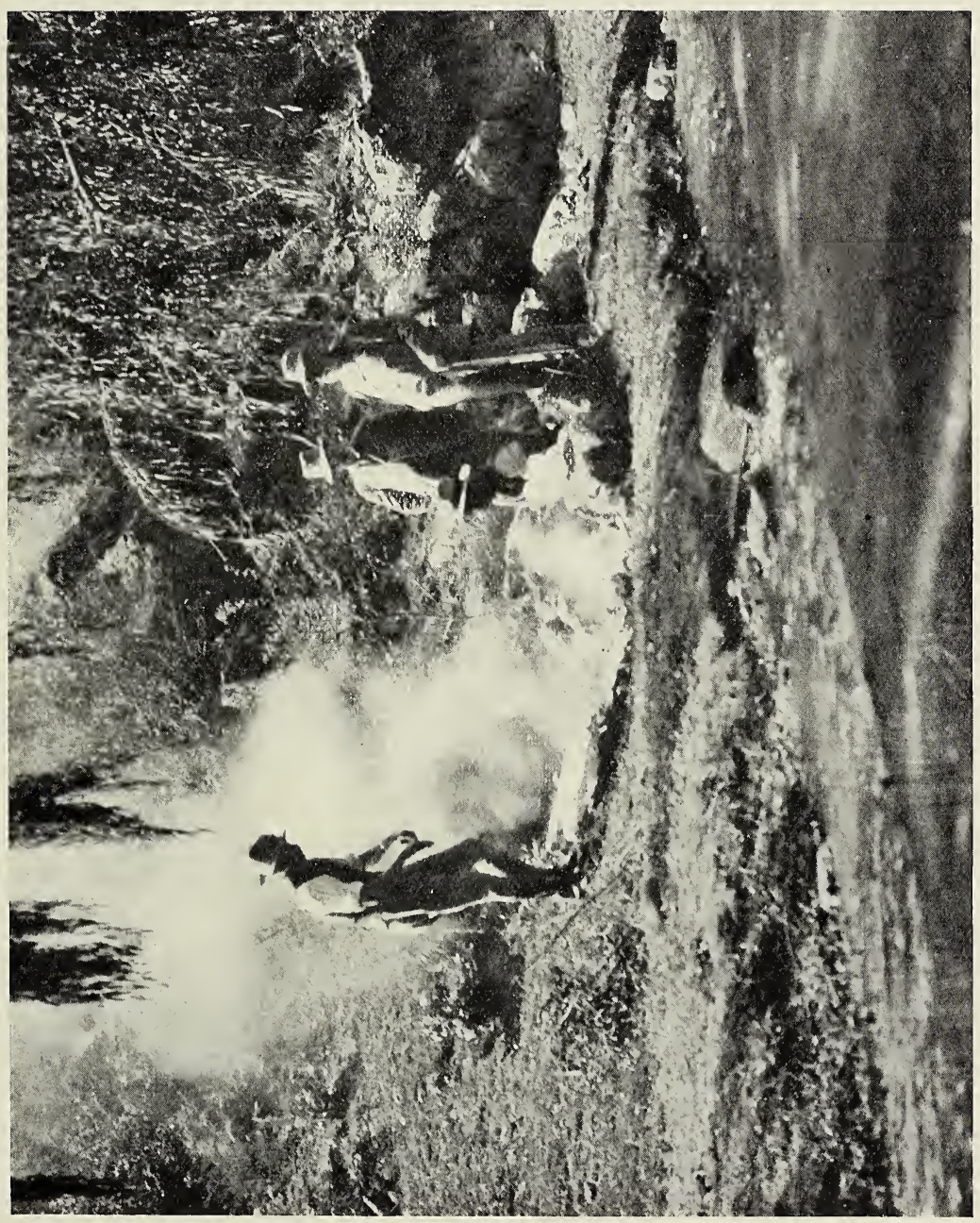



LUNCH AT THE CAVES. 
. RITHAD THYI 'IA M'JATSX 


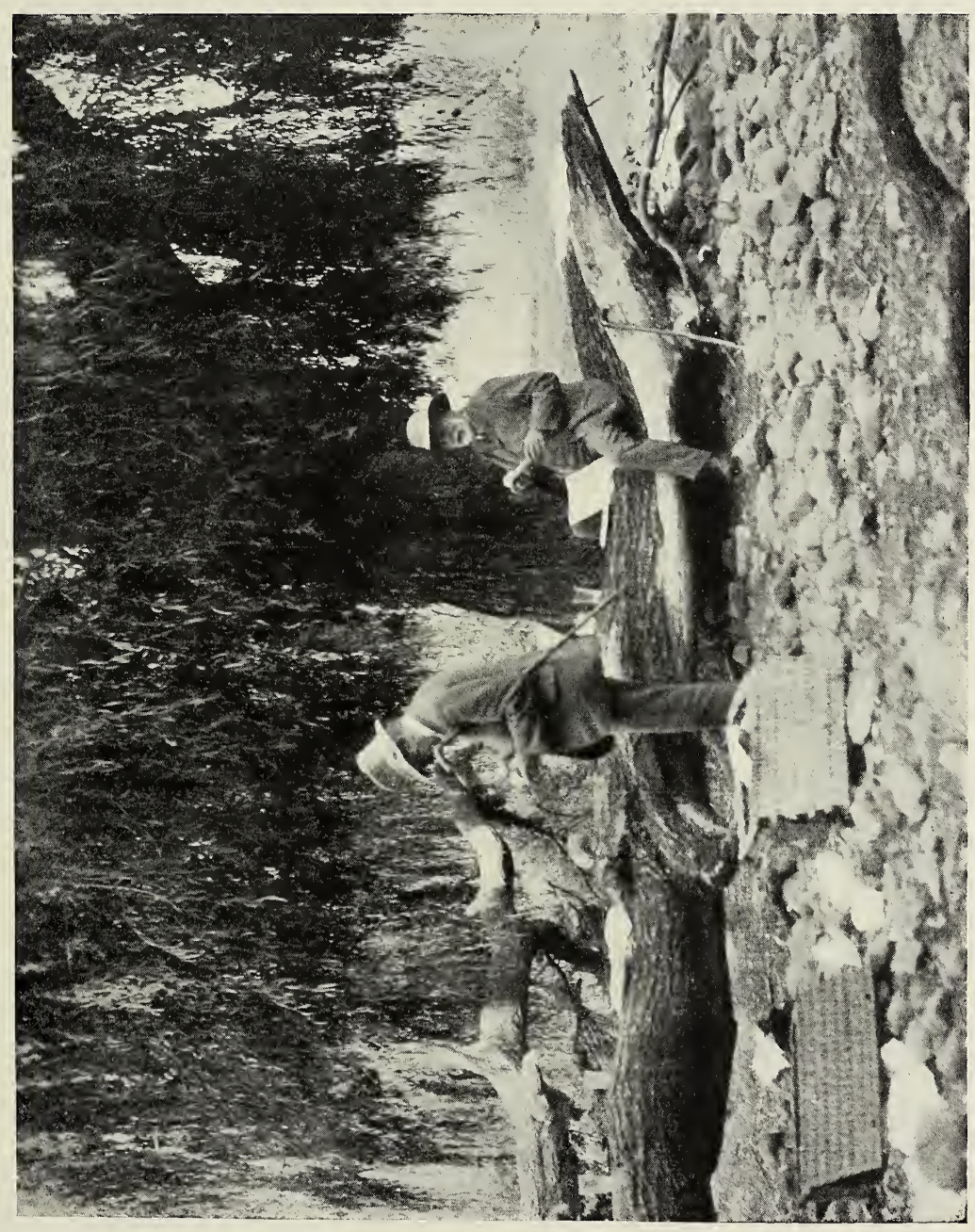



Diary of a Tour in South Africa. 53

cases as large and lofty as in a cathedral of the largest dimensions. It was insufferably hot in the Caves, and in many cases very slippery, so that after an hour's groping about in the semidarkness of candle-light, and with a plentiful use of magnesium ribbon in the larger chambers, we all thought we'd had about enough of it. Unfortunately, our guide, a Dutch boy of about fourteen, could not understand English, and we had some difficulty with him, but I managed to make him understand a good many things with the help of German, and as I had not been able to get him to understand any English, I naturally tried to make him understand in German that we wanted to "Go out," and tried all the words in that language which had any sort of connection with getting outside again-all without result. Then Guntrip simply said to him, "Go out," and out we went. I really do the youth an injustice in saying that he knew no English. Being commissioned 
54 Diary of a Tour in South Africa.

to ask him what the charge was for admission, he promptly replied, "Two bobs for one," which was true; but the young rascal failed to tell us what we afterwards found out, that it should have been six bobs for four. However, he was given ten bobs, I suppose because he seemed a nice boy; and I daresay he continues his career of swindling to this day, with much advantage to himself. After a pleasant drive back, we reached our car about six o'clock, and found the Professor up, looking distinctly better, and entertaining Mr. Olivier, the leading ostrich farmer of the district, who with his wife had called on us. They left soon after we arrived, and we dined, and after a few games of Bridge turned in for the night, as we were all very tired.

April 9.

We are having a quiet day after our fatigues of yesterday. As we got our home mail last 
FEEDING OSTRICHES WITH LUCERNE. 



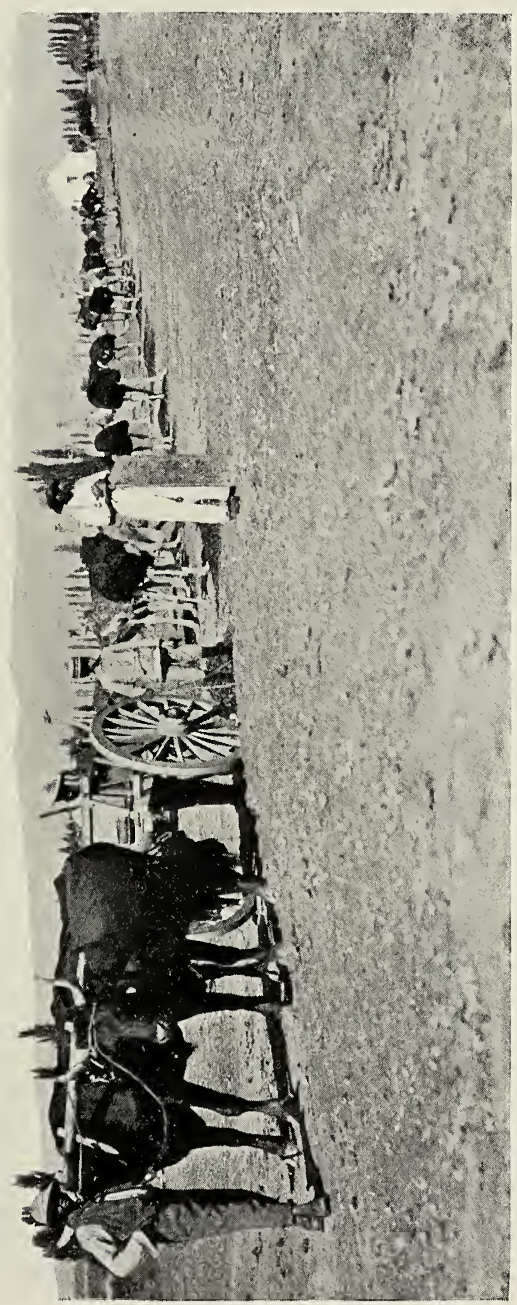



Diary of a Tour in South Africa. 55

night, the first news we have received since March I 3, some of us spent the morning writing home, and in other quarters the newspaper was much in evidence. After the heat of the day was past, Mr. Dan and I had a stroll as far as the fine bridge which spans the Oliphants River, during which we met a number of ostriches, driven by Kaffirs, which took no notice of us. Not so, however, an old cock bird in one of the fields, who continually charged down upon us, but was brought up by the high barbed wire fence which fortunately was between us. We have had most abominable water in our tanks for the past few days, picked up at some out-of-the-world tank, and we are thankful that they have been refilled to-day with most excellent water, of which Oudtshoorn has a plentiful supply, brought down in pipes from reservoirs in the Zwaartberg. 
April ro.

This morning just as we had finished breakfast we received a visit from a Dr. Russell formerly of Barrhead, and a Mr. Burdett of Springbuck football fame. Each of them brought their own motor car, and very kindly took us for a long and most interesting drive over the Veldt, Mr. and Mrs. Olivier being also of the party. We returned to the car for lunch, and shortly after had a visit from a Miss Jessie Hutton, a connection of our host's, and from whom we got a lot of interesting local information, as she lives in the district. About four o'clock, Mrs. Olivier sent her carriage for us, which took us to her house, where we had tea, and afterwards enjoyed the lovely views from her beautiful home. We were interested to hear that they have a daughter at school in London, and a son at Cambridge. Mr. Olivier is the owner of about 10,000 ostriches. 
A BLOCK HOUSE-

A REMINISCENCE OF THE BOER WAR. 



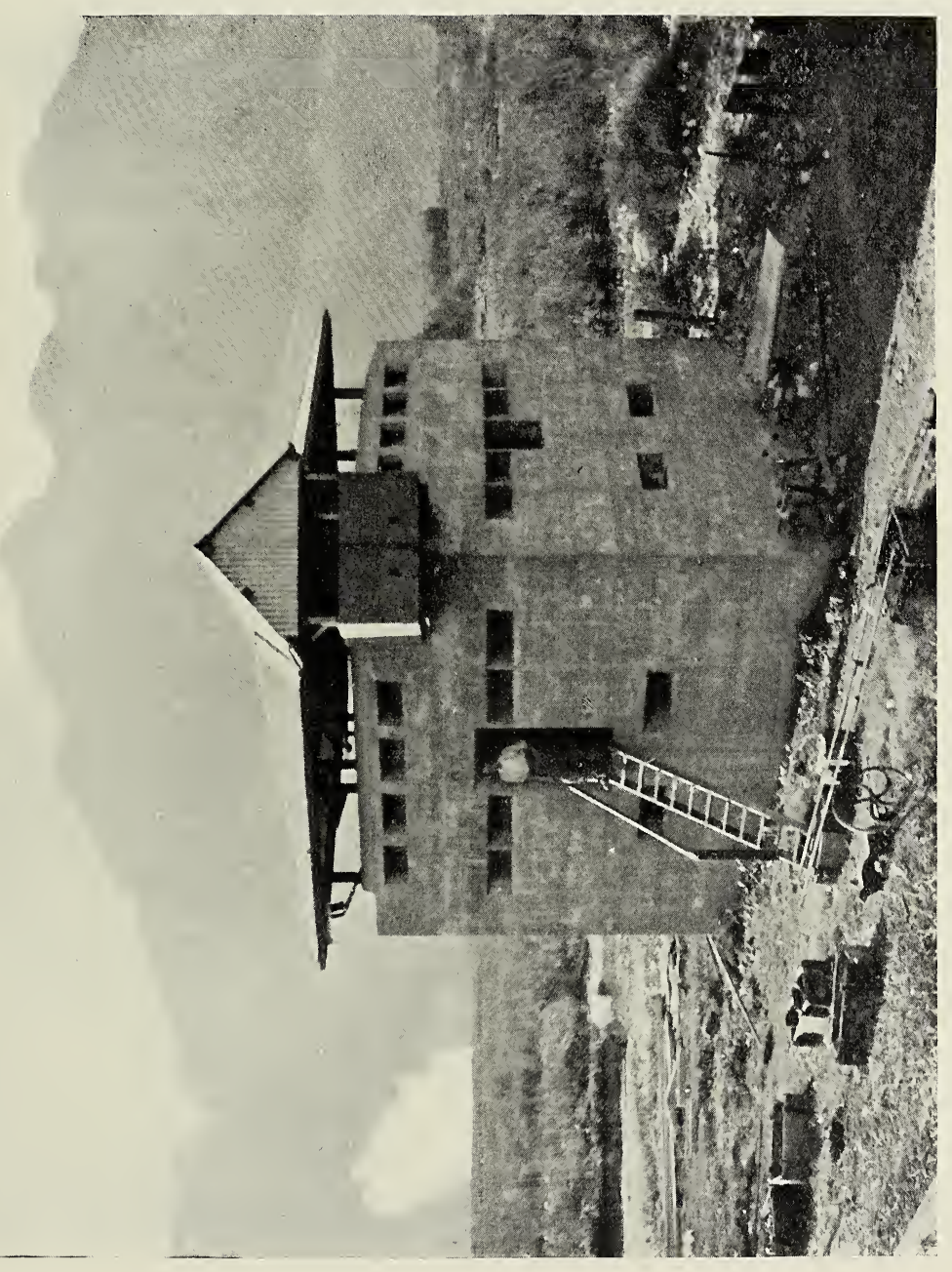



April I I. Easter Sunday.

We left Oudtshoorn this morning at 9.30 , by the first train to depart in the direction we wish to go since last Thursday, and have reached Klipplaat Junction at I0.35 P.M. Nothing of note the whole day, except the re-passing of the Toverwater Poort, which again had not sufficient light for photography in a moving train, for which I was more than sorry, as several portions of the pass were extremely fine. At the various stations we passed, the Kaffirs in their Sunday clothes caused us much amusement. A large, coloured patch on what were apparently quite new trousers, seemed to be the principal adornment of the men, and the girls appeared always in very bright blouses of the most astounding hues.

The run for the day has been I 54 miles, and we have now travelled I,064 miles from Cape Town. 
April I 2.

We have been obliged to lie in a siding all night at Klipplaat Junction, in order to get on to the Port Elizabeth train at 10.50 this morning, whither we are now bound. The features of to-day have been dust-storms and cloud-bursts. Very soon after leaving Klipplaat we noticed a whirlwind carrying a spiral column of dust apparently right up to the clouds, and later on we saw two cloud-bursts, and in passing over the district where it had occurred, we found it completely swamped for a couple of miles. We got into Port Elizabeth at eight o'clock, just as we had finished dinner, and having first seen the stationmaster and arranged for a much needed supply of fresh water, we went for a short stroll in the town, but there was not much to be seen, and the shops were mostly closed.

Run for the day, I 24 miles-travelled from Cape Town, I, I 88 miles. 
Diary of a Tour in South Africa. 59

April I 3 .

We have spent to-day seeing the sights of Port Elizabeth, known locally as the Bay, and the inhabitants as Bayonians. It is a nice clean town, with many good shops, and everything has a prosperous look about it. For a change we lunched at the Grand Hotel, which seemed to be entirely staffed with Indian waiters, and in the afternoon we had a fairly long drive to a point on the coast called Schumacher's Kop, the drive being chiefly remarkable for the large number of horse flies by which we were beset during a portion of it. At 9 P.M. we again started on our journey, and shall not reach our next stopping place, Kubusie, till about 9 P.M. to-morrow night.

April I4.

To-day's journey has been a most interesting one from first to last, with an entire absence of desert, of which we have had quite enough 
for the present. We have come by way of Alicedale and Cookhouse Junctions, and King William's Town, or King as it is generally spoken of, the ancient capital of Kaffraria. The soil of the Eastern Province of Cape Colony appears to be very fertile; there is much pasture land, and large flocks of sheep and cattle are to be seen, throughout every part of the Province we passed through. The configuration of the country generally, reminded us of home more than any part we have yet seen. All day we have been passing hundreds of Kaffir kraals and huts, which were about the only things that there were to remind us that we were not passing through some district of Scotland or the North of England. At about 9 P.M., we arrived at our destination, Kubusie, where we were to visit Mr. Andrew Coats and his family at Stutterheim. I should have mentioned that, during to-day's journey, we passed Alice, at which place is located the 
Diary of a Tour in South Africa. 6I

Lovedale Mission, an institution well known in Scotland. We were also at Blaney Junction, twenty-four miles from East London, this latter place not being considered of sufficient interest to include in our tour. We have had some difficulty in getting into a siding here for the night. Either the car was too long, or the siding was too short, but, whichever way it was, the engine could not get out of the siding after backing us into it, and another siding had to be found, with the result that the train was delayed some thirty minutes. I am confident such a car as ours never spent a night at Kubusie, and is hardly ever likely to do so again.

Run for the day, or rather twenty-four hours, 297 miles, which, as will be noticed, is certainly not an excessive speed, working out as it does at between twelve and thirteen miles per hour; but of course stations in this district are fairly frequent, and stoppages generally 
62 Diary of a Tour in South Africa.

long. We have now come 1,485 miles from Cape Town.

April 15. Kubusie.

This place we found out this morning, is a very diminutive station, not a single house being visible from it, and it is on the direct line from East London to Bloemfontein and the Transvaal. Stutterheim, our destination, beautifully situated at the foot of the Amatola Mountains, three and a half miles from this place, got its German name from a number of settlers from the Fatherland who came to this district many years ago, and there is still a Lutheran church in the place.

At 9 A.m. Mr. Andrew Coats arrived with a conveyance to drive us to his house, which we reached in due time over a tolerably good road. It was a very hot morning, and we were glad enough to seek shelter in the cool shady rooms from the glaring oven outside. 
MR. ANDREW COATS" HOME AT KUBUSIE. 



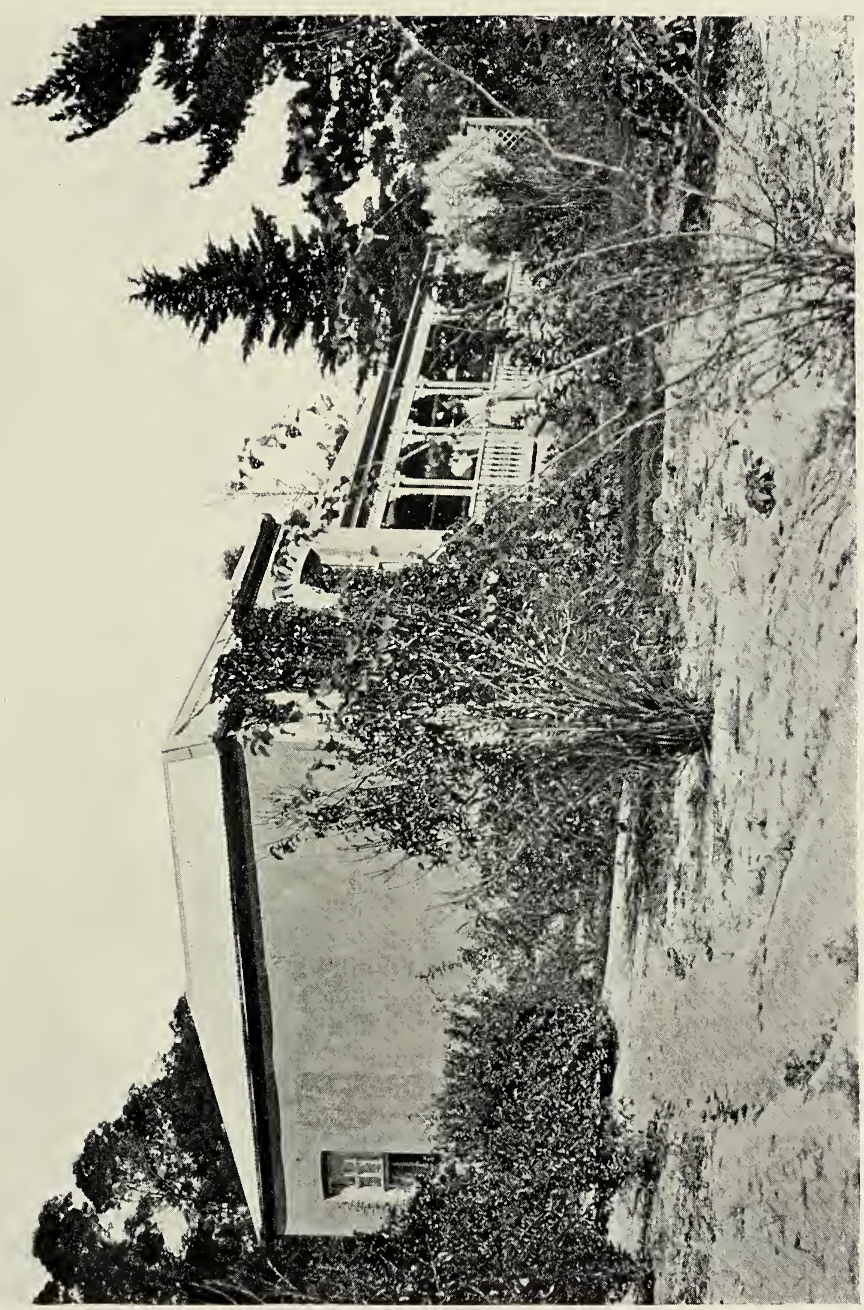



Diary of a Tour in South Africa. 63

Our visit here was a short one, as we were due to leave Kubusie at 1.7 P.M. for Bloemfontein ; so, after a little talk, a little refreshment, and a few photographs which I took of the family in their garden, we said our "Farewells," and Mr. Coats took us back to the station and saw us coupled to the train for Bloemfontein.

April i6. Bloemfontein.

We have now come 1,828 miles from Cape Town, and arrived here early this morning. During the night we crossed the Orange River via the Bethulie Bridge, since which we have come on to the Central South African Railway system, the railways in both the Orange River Colony and the Transvaal being owned by that Company. We began the day with a disappointment, as there was no sign of letters or newspapers from home, and they should have arrived here yesterday at latest. Some fool has blundered! After making vain in- 
quiries at the station and post office, we gave it up. Later on in the evening it was reported to us by a guard that he had seen our letters in a train on the way to Kimberley. We shall not now get our mail till we reach Ladysmith, and we quite failed to find out what idiot had perpetrated this little abomination, as whatever views one may have at home about the receipt of letters in the ordinary way, one is glad enough to get them when home is many thousands of miles distant. As usual, I paid my visit to the Surveyor of Customs, and, as usual, found him most courteous and obliging, which was something to be thankful for. We lunched at the Imperial Hotel, and afterwards drove out to the Cantonments where the Professor hoped to find a relation, but, unfortunately, he had left a few days previously. There are about 3,000 British troops quartered here.

Bloemfontein was not a bit interesting; but 


\section{BLOEMFONTEIN.}





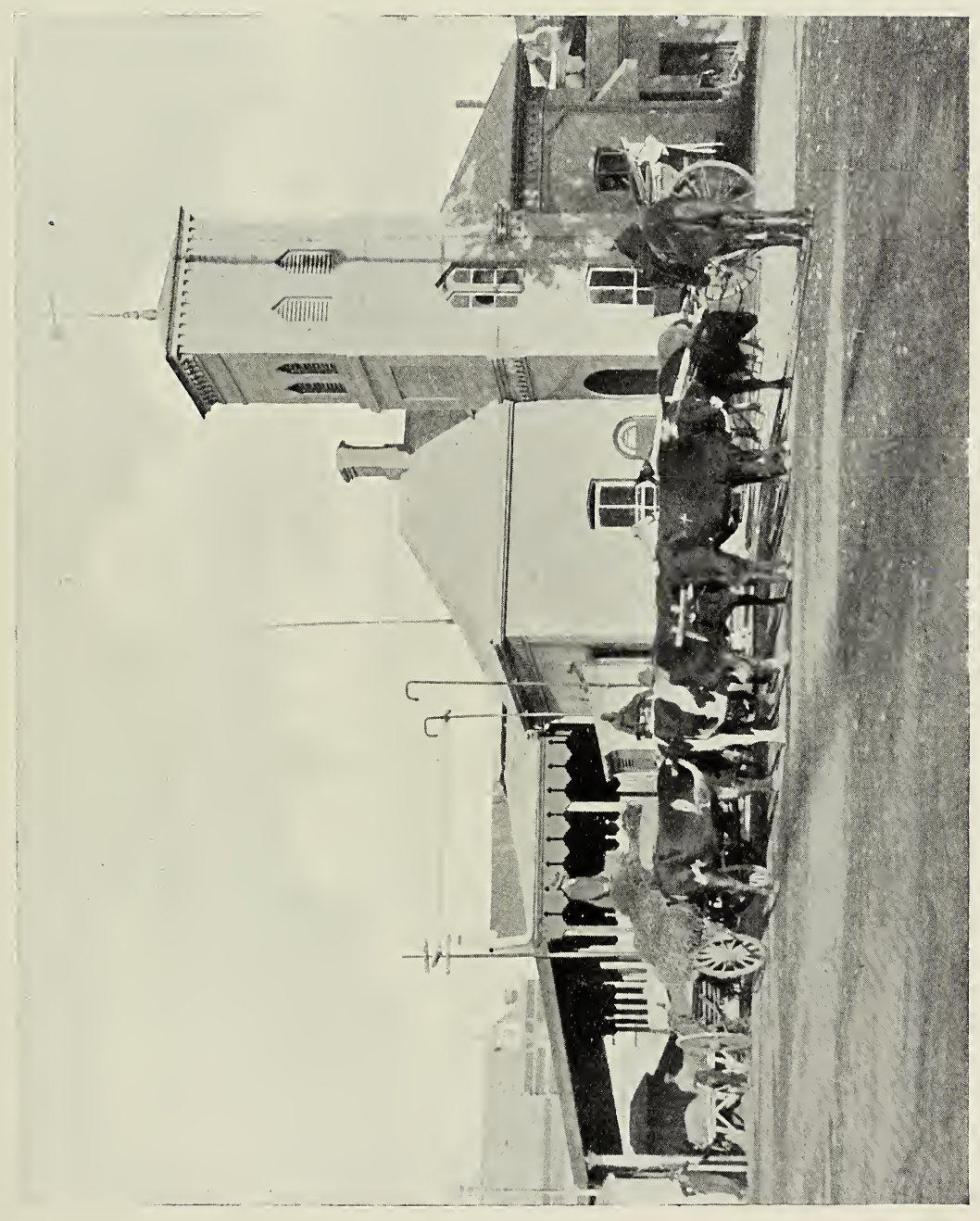



Diary of a Tour in South Africa. 65

it looked very clean and prosperous, with many excellent shops, all in the hands of Britishers; indeed, I heard nothing but English spoken by white people in the streets, which is a little surprising, when one remembers that until as late as March I2th, 1900, this place was the Capital of a Boer Republic. Cabs were costly here-7s. $6 \mathrm{~d}$. per hour, and something as usual for the driver. In the evening we visited a roller skating rink (no roof), crowded with men and women, Thomas Atkins being much in evidence.

\section{April 17.}

We left Bloemfontein at nine o'clock this morning, and, after reaching Marseilles, which is the junction for a branch line to Maseru, the capital of Basutoland, we were soon travelling along the border of that country, and all the afternoon had excellent views of its magnificent mountains and plains, extending as far as the 
Maluti range, situated in the heart of that country, and whose highest peak is about I I, Ooo feet. During the afternoon we passed several Basutos mounted on their famous ponies, accompanied by their hunting dogs. They made a most picturesque group on the veldt, which I was fortunately able to capture. We reached Ficksburg between 5 and 6 o'clock. It is most beautifully situated, at an altitude of 5,345 feet, and now at I0.30 P.M. we have just arrived at Bethlehem, where we have a wait of half an hour, and then go on to Ladysmith, where we expect to arrive at 8 o'clock to-morrow morning.

The run for the day has been 188 miles. Miles travelled from Cape Town to date, 2,or 6.

April i 8. Ladysmith.

When I got up this morning, I found we were shunted into unusually pleasant quarters. Instead of the usual goods yard, we were right 
BASUTUS AND HUNTING-DOGS. 



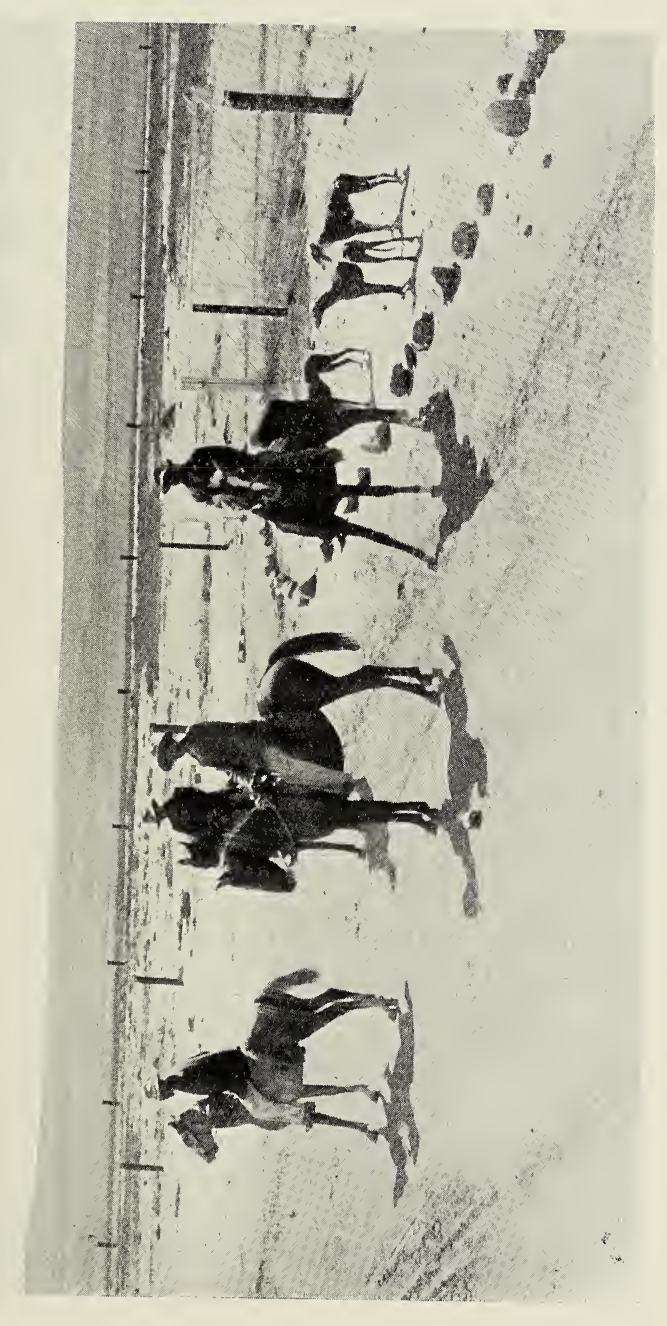



Diary of a Tour in South Africa. 67

away from the station on a siding under some nice shady trees. For this delicate attention I believe we had to thank Mr. Littlejohn, the superintendent of this section of the Natal railways, who had received instructions from Durban to make us comfortable, and give us any necessary help to see the battlefields of this district. Unfortunately, we have had to miss the scenery of the Drakensberg Range, as we came over the Van Reenen Pass $(5,500$ feet) during the night. It was through this pass that the Free Staters advanced on Ladysmith. The Orange River Colony frontier is in the neighbourhood of Van Reenen, and since passing it we have come on to another railway system, that of Natal.

After breakfast we climbed Convent Hill, behind which our naval guns were placed during the siege, and from the top we were able to get good views of all the important points held by the British and Boers. After 
68 Diary of a Tour in South Africa.

lunch we were introduced to the guide to the district, a Mr. Cauldfield, who is an official of the Natal Government: a military-looking man, with the elegant and inspiring title of "Curator of Graves," whose office is to see that the numberless graves on the battlefields of Natal are kept in decent order.

We drove in two Cape carts under his guidance to visit Waggon Hill and Caesar's Camp, both the scenes of fierce fights, and crowded with the graves of the fallen. This was our first experience of a rough drive, the latter part of it being practically roadless. In driving back to our car, we went into the Episcopal Church, which has been enlarged as a memorial to the fallen, the walls of the transepts of which are covered with tablets containing the names of all the men who had been killed in action, or had died of disease during the siege, and it was an appallingly long list $(3,200)$. We also visited the Town Hall, which still shews traces 
LADYSMITH, FROM CONVENT HILL. 



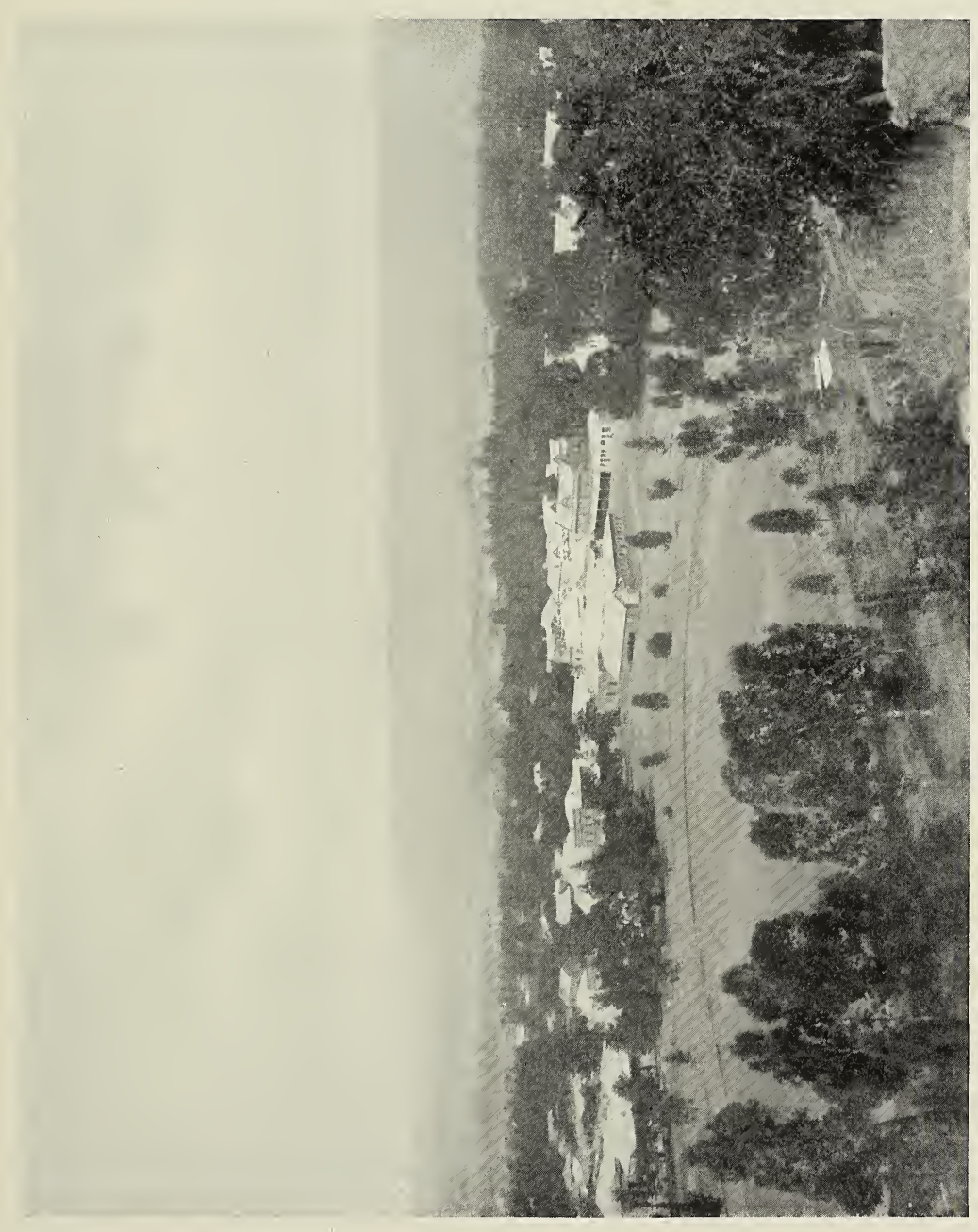



SPION KOP. 


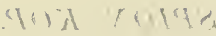




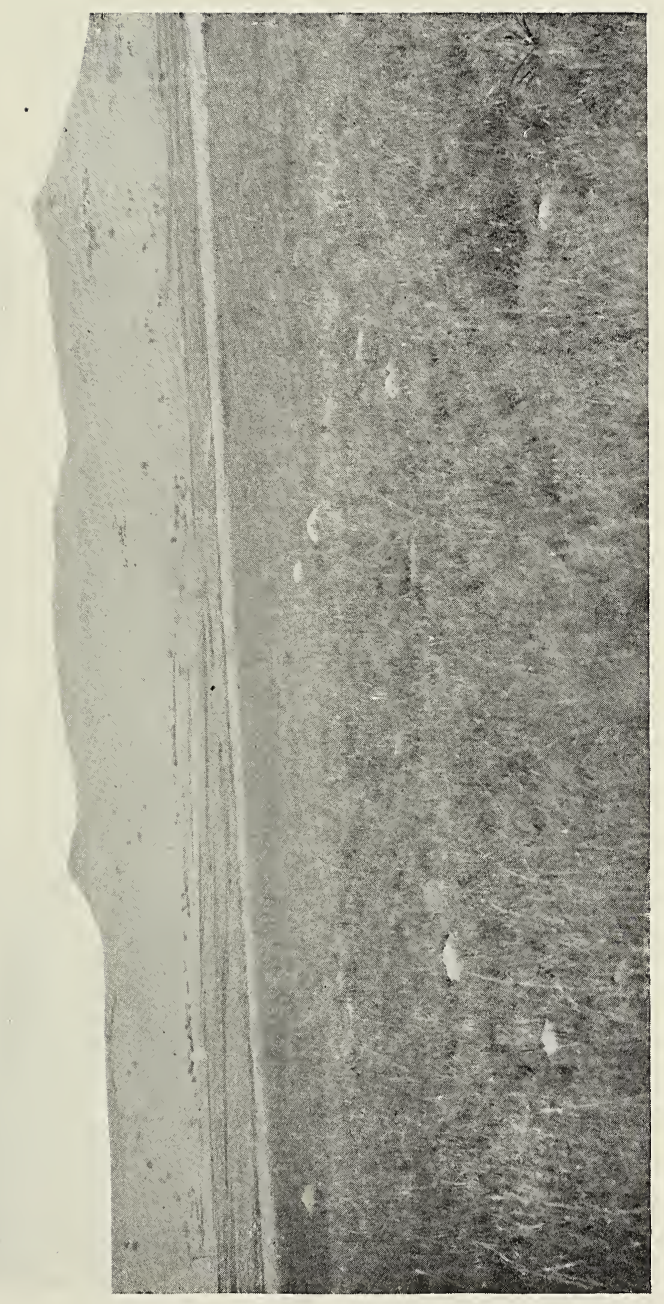



Diary of a Tour in South Africa. 69

of the siege in the tower wrecked by a Boer shell. This is being preserved as a momento of the fierce struggle which raged round the town, from October, I899, to February 28, I 900.

Our journey last night, Bethlehem to Ladysmith, was I 26 miles-total since leaving Cape Town, 2, I 42 miles.

We are hoping to have a quiet night, and as we shall have a fatiguing day to-morrow at Spion Kop, we are going early to bed.

April 19. Spion Kop.

For fatigue, this has been a memorable day in our trip. We left the car at 8 A.M. in a sort of covered waggonette, drawn by four good mules, accompanied by the before-mentioned guide, our destination being the top of Spion Kop, some twenty miles distant. The drive was over quite a decent road for the first ten miles or so, after that it was across the veldt, 
70 Diary of a Tour in South Africa.

and rather trackless and rough in places, which made it slow travelling, consequently we did not reach our destination till about i I o'clock. It was decided that we had better do our climbing before lunch, so we lost no time in starting. Our "Curator of Graves" told us it was 500 feet to the top, but whether he "lied" to encourage us, or whether the awful heat and glare of that African sun magnified it to 1,000 feet, I cannot say: all I know is, that at the end of the ascent, which occupied about one and a half hours, I felt fairly exhausted, and would have given a great deal for a drink of any kind; and one could well imagine the thirst of the British soldier as he lay there for hours in the blistering sun, exposed to the Boer fire from their invisible rifle pits, particularly when one remembered that the battle of Spion Kop was fought on January 20th, I 900 , just about mid-summer, and we had found the heat almost unendurable for climbing on an 
THORNYCROFT'S POSITION-SUMMIT OF SPION KOP. 



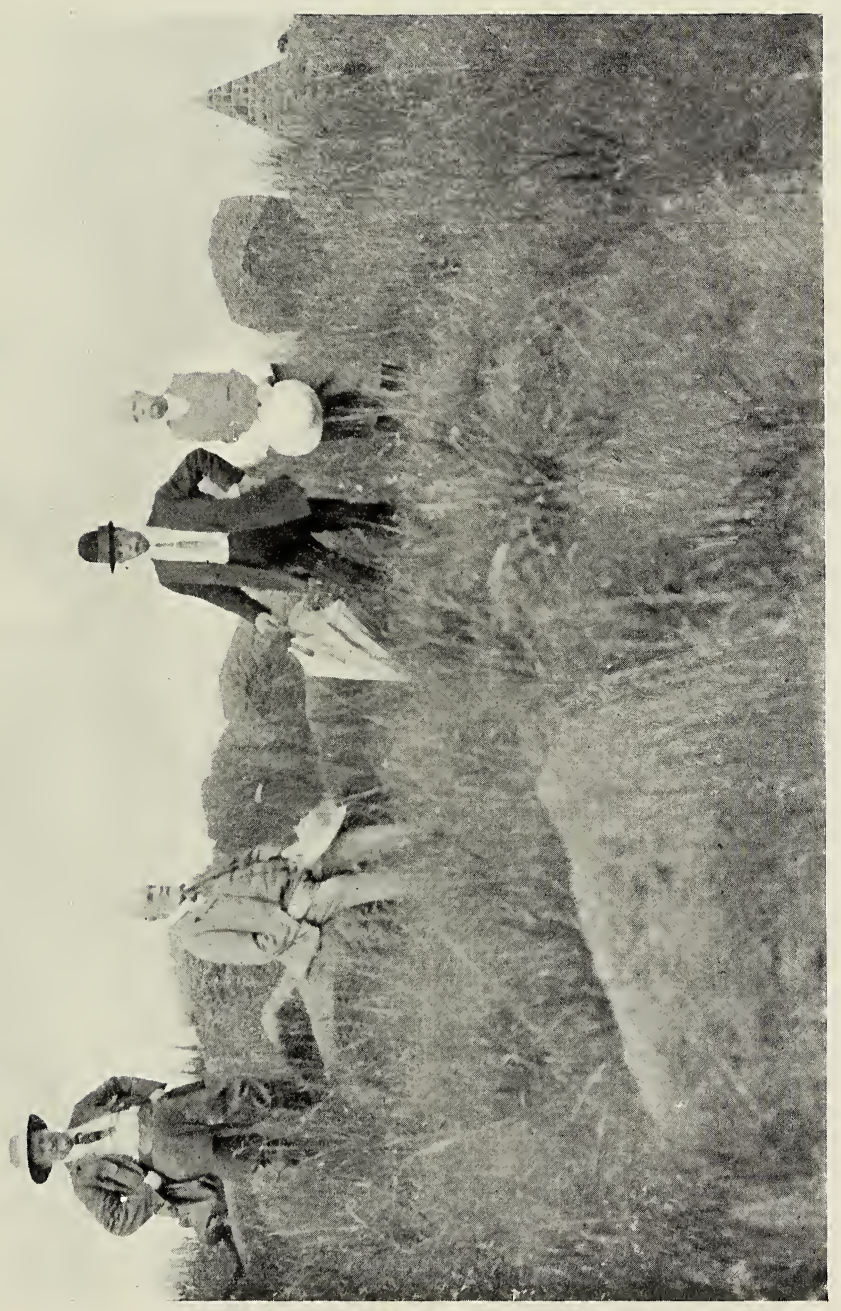



Diary of a Tour in South Africa. 71

autumn day in April. We spent about an hour on the top, and it was a sad sight to see the long trenches where the dead had been buried. There is also a number of very handsome monuments ; in fact, the whole top of Spion Kop looks more like a cemetery than anything else: our loss being 675 men killed, including those who died of their wounds.

The verbosity of our guide was extraordinary, even for a guide, but this is no place for his explanations as to why the attack failed, etc. etc.

We reached the base and our lunch about 3 o'clock, and, needless to say, we were quite ready for it, as we had breakfasted at 7 A.M., and my recollection of that affair is that I was almost past eating, but by no means past drinking, and that the supply of liquid of various kinds was unlimited.

At 4 o'clock we started on the homeward journey, and reached our car at 7 P.M., leaving Ladysmith forty minutes later for Colenso, the 


\section{Diary of a Tour in South Africa.}

scene of another ill-fated attempt, which battlefield we are to visit to-morrow. It is only seventeen miles distant from Ladysmith, and we arrived there just as we were finishing dinner. After a smoke and a few games of bridge, we were all glad to turn in early for the night, as the fatigue of the day had not been light.

Miles travelled from Cape Town, 2, I59.

April 20. Colenso.

The present-day boy will associate this name with a battle, just as the boy of my day associated it with an Arithmetic. Last night we slept on the battle-field, as the little station and siding where the car rested for the night is in the midst of that scene of British disaster. Soon after breakfast, under the guidance of the very intelligent stationmaster, a man who had served in the war, and seemed to know what he was talking about, we set out to survey the neighbourhood. The 
BATTLEFIELD OF COLENSO. 



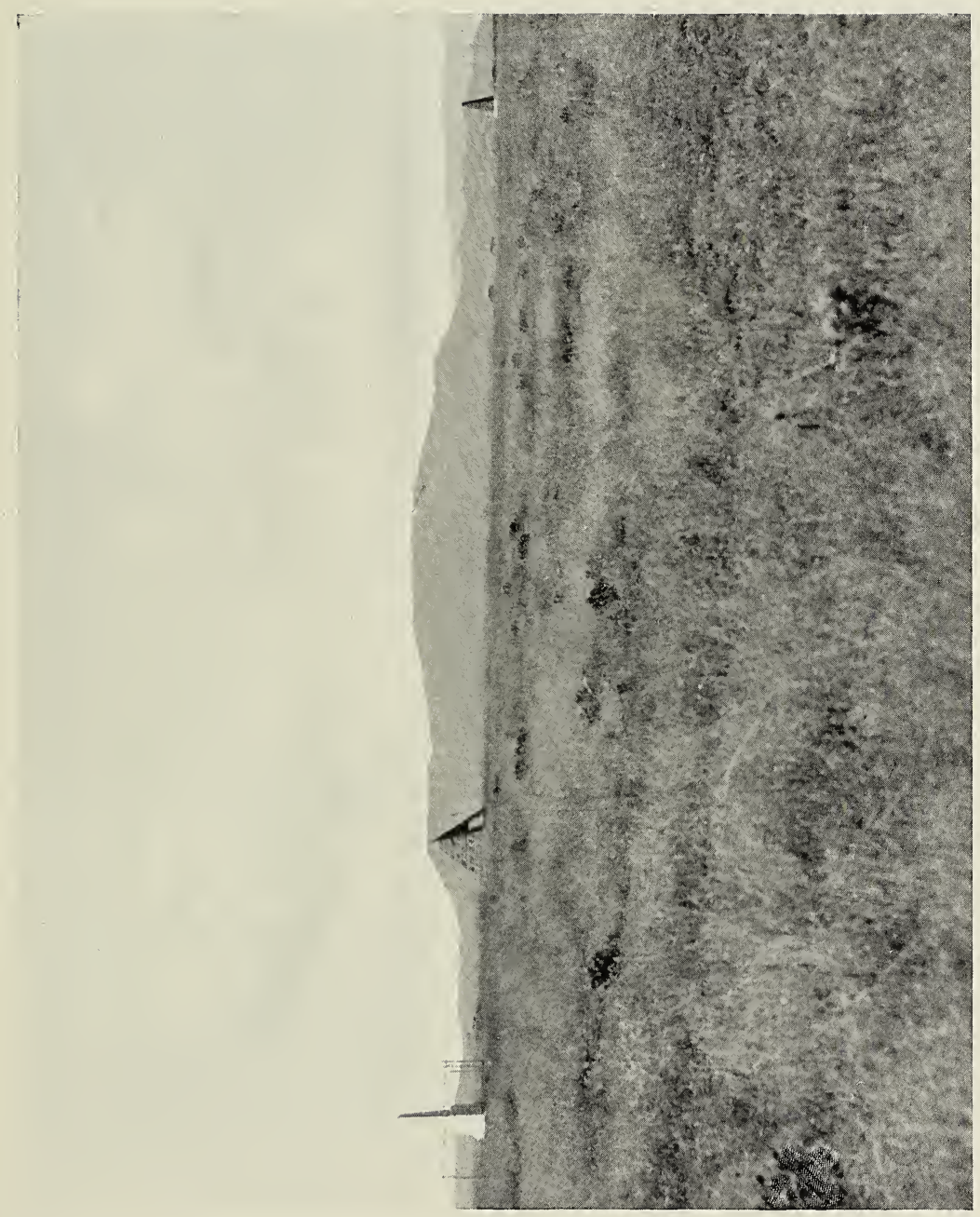



first thing we came across was a roughish notice board nailed to a stake, which informed us that at this point the British guns (nine, I think) were lost, and one could only ejaculate, "Little wonder!" after it was pointed out to us that, within a couple of hundred yards of the spot, hundreds of expert Boer riflemen were concealed in thick bushes, and in behind the railway embankment, a position from which they could easily pick off both horses and men the moment the guns reached the spot, the said guns being quite out in the open. However, a traveller's diary is no place for this matter, and, anyhow, British disaster is not a pleasant subject to write about. We saw also the spot, marked by a pyramidical monument, where Lord Roberts's son fell in a gallant attempt to bring in the guns from that fireswept zone, also numerous other monuments of interest. After lunch, we drove right across the battlefield for a few miles and climbed a 
74 Diary of a Tour in South Africa.

hill called Snake Mountain, at which place the Boers had mounted a heavy gun, which commanded the battlefield. Coming down, we found the Laird (who had had enough of hill-climbing the day before at Spion Kop) inspecting a Kaffir hut, or rather two huts, one of which was apparently used by a Kaffir for the manufacture of tobacco, and the other for housing two or three wives. I was able to get a photograph of this domestic scene. We then returned to our car, having had rather a rough drive, in one place, I remember well, I just managed to save myself from being sent sprawling out of the back of the cart. We are going to have a quiet night on our siding, and leave in the morning for Durban.

April 2 I.

We left Colenso at 9.49 this morning, and after a run through the most glorious country (much the finest we have seen so far), we 
KAFFIR'S HUT-COLENSO. 



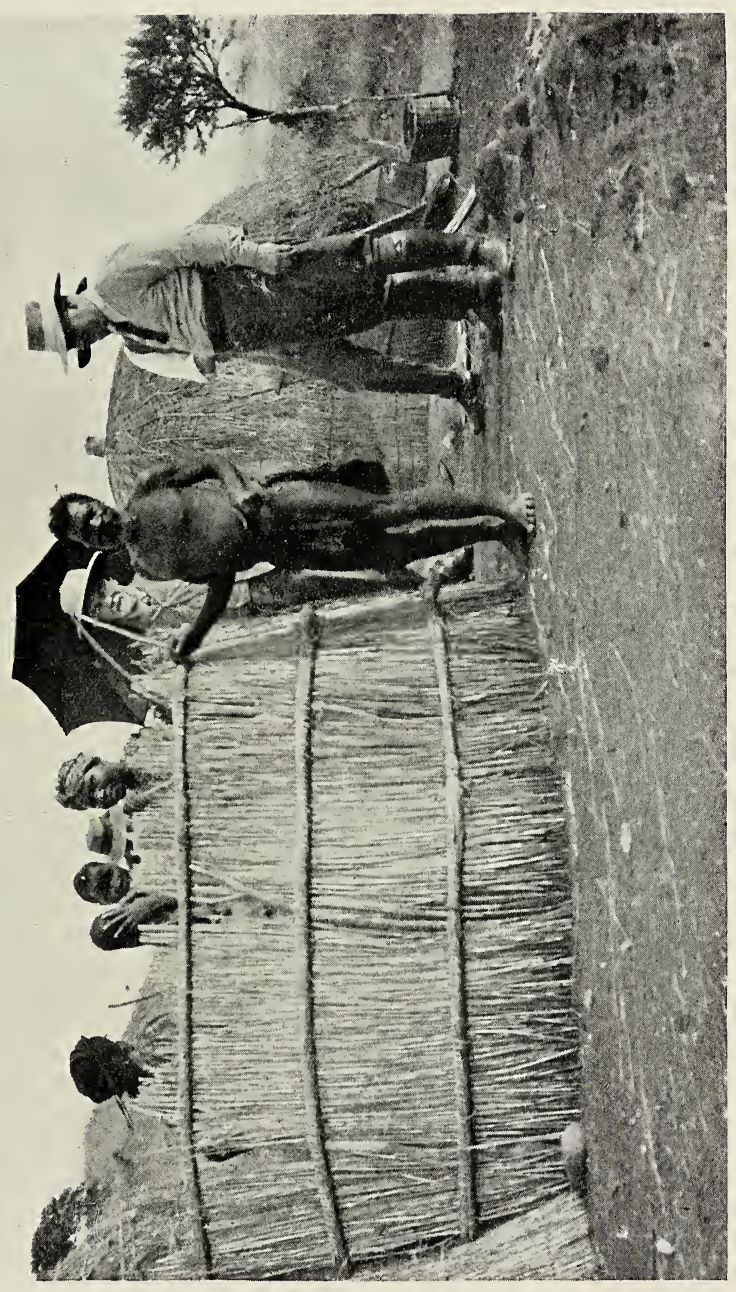



Diary of a Tour in South Africa. 75

arrived at Durban about 7.30 P.M. That railway journey is really most extraordinary, made up as it is of steep gradients, I in 30 , and very sharp curves.

This night, anyhow, is not going to be a quiet one. As I write at nearly midnight, we are fixed up for the night in the very midst of the goods yard, and trains are shunting and screaming all around us. In all my life I never went to sleep in the midst of such a veritable pandemonium, but $I$ found in the morning that my bedroom companion had not fared so well, neither did I on the succeeding nights of our stay in the midst of that hideous cacophony.

We have travelled to-day, Colenso to Durban, I73 miles, and in all from Cape Town 2,332 miles.

Aprii 22. Durban.

Our first proceeding after breakfast was to go in jinricshaws down to the beach, which was 
a nice change from our home in the goods yard. The pier is built in the form of a large crescent, and in the enclosure the bathing takes place. It is protected against sharks with a strong iron fence all round. Occasionally, I believe, a shark manages to break through, and then the bathing ceases for a while. We lunched at the Marine Hotel, and afterwards I paid my usual visit to the Surveyor of Customs in order to get our papers for the Transvaal.

This seems a nice town, and is very English, but we all feel it exceedingly hot and relaxing down again at sea level, after having lived at altitudes ranging from 3,000 feet and upwards for the past eighteen days.

\section{April 23. Durban.}

There is not much to be said about our stay here, as, with the exception of numberless jinricshaws and a certain proportion of coloured people in the streets, one has a home-like 
PIER AND SHARK-PROOF BATHING STATION, DURBAN. 



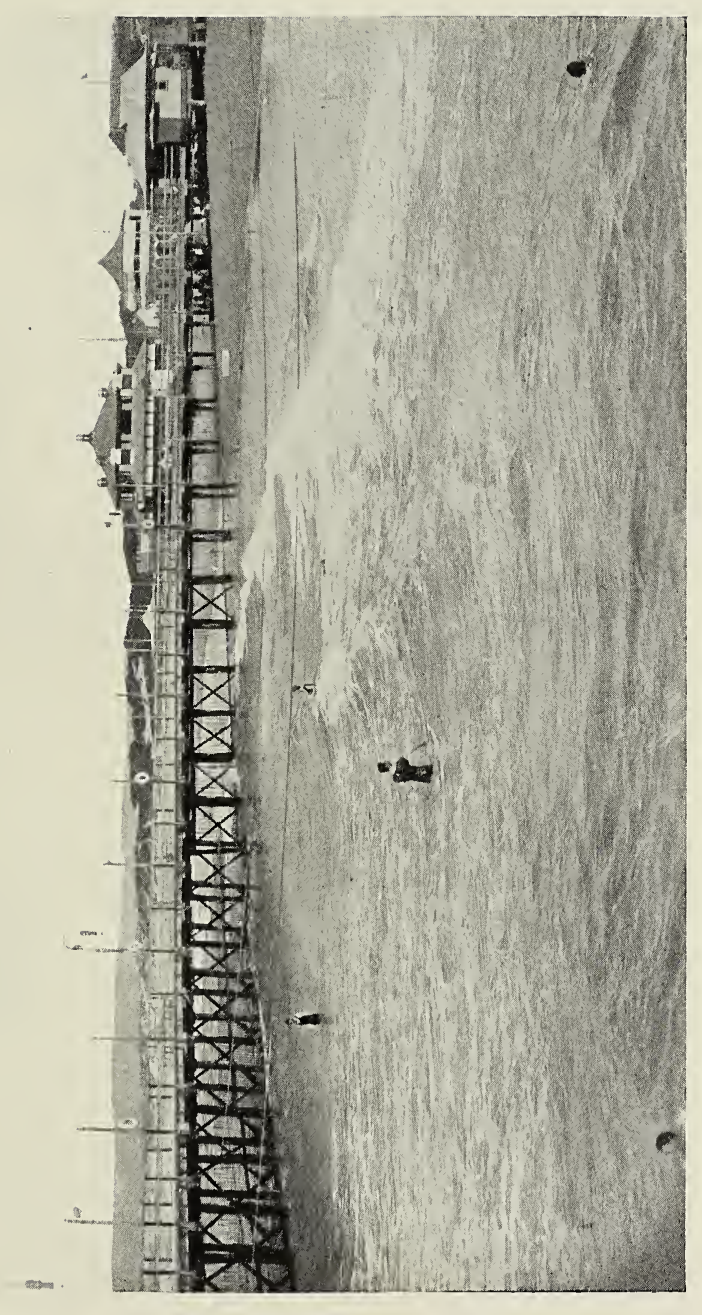



JINRICSHAWS AT DURBAN. 
.

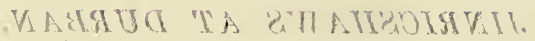




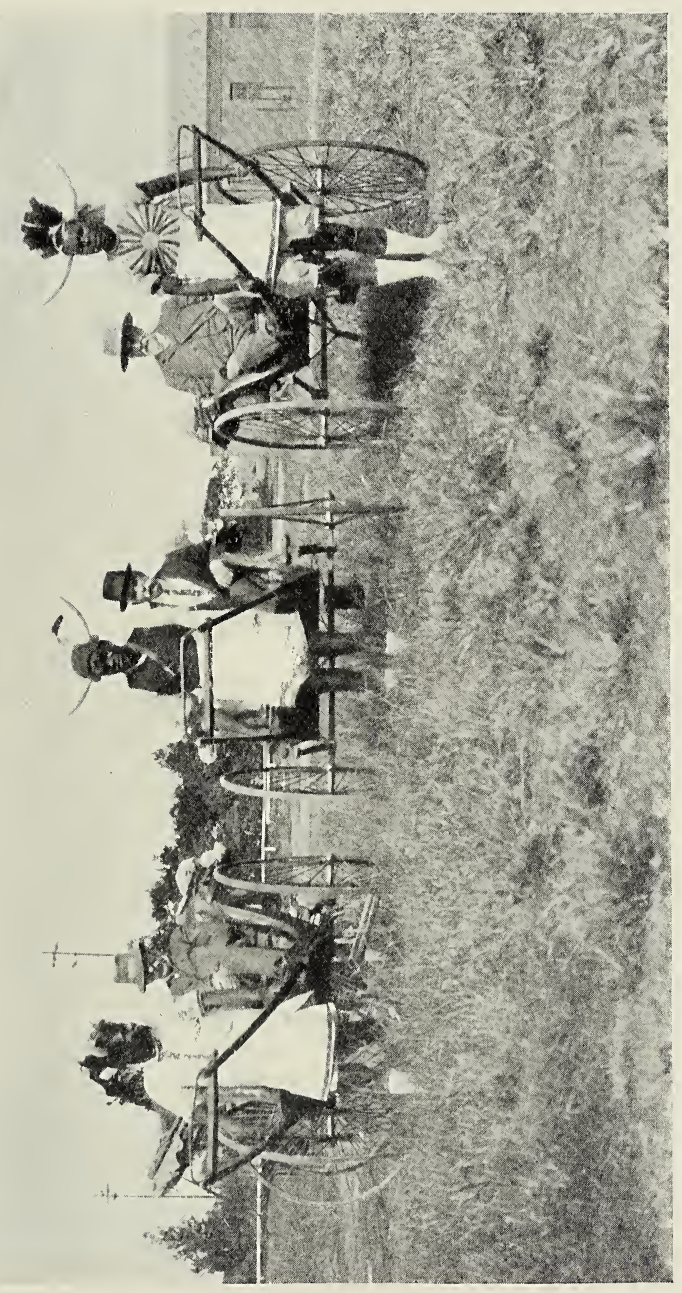



A PROMENADE À JINRICSHAW. 


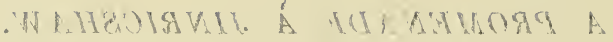




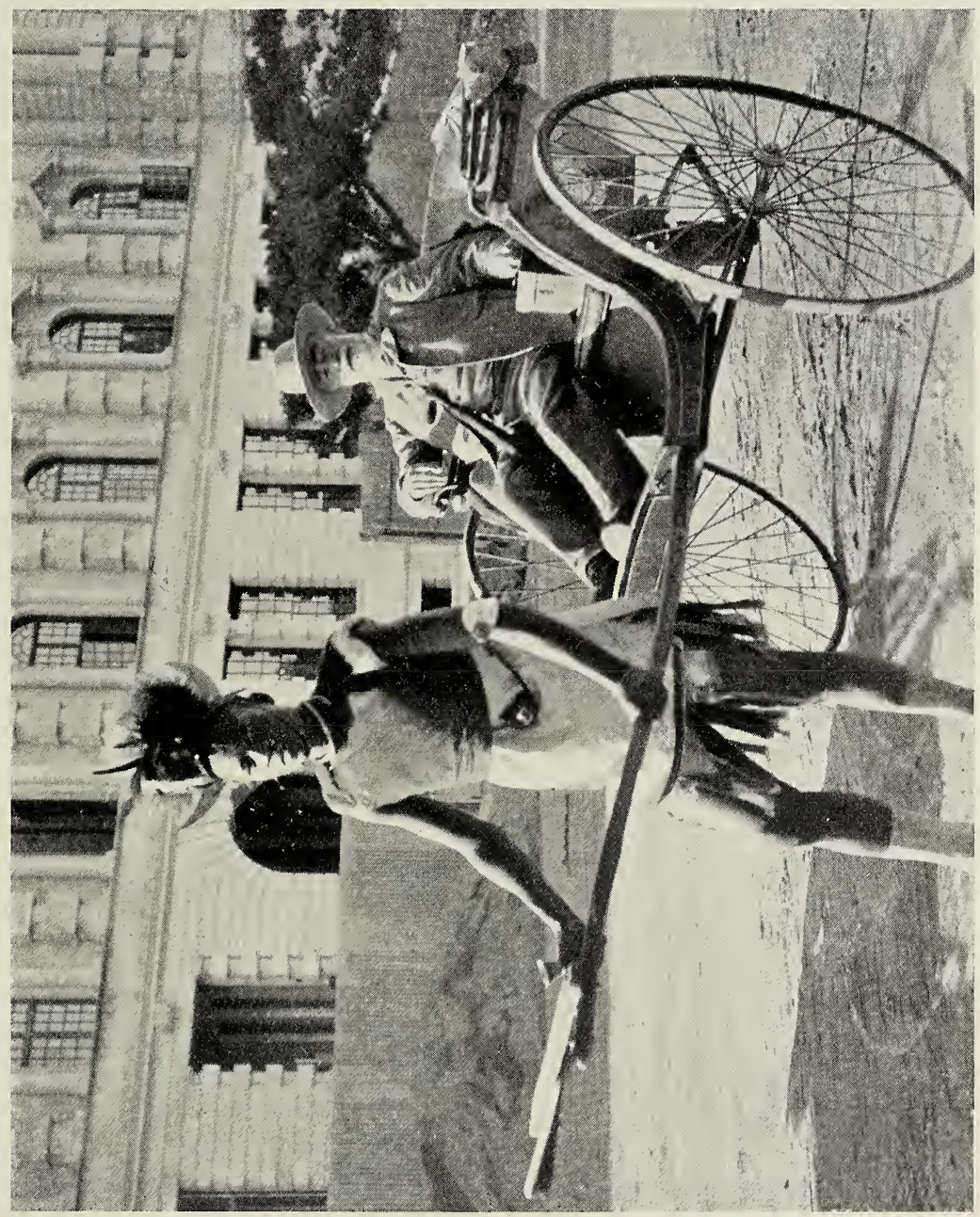



Diary of a Tour in South Africa. 77

feeling, as shops, streets, and public buildings generally, were very much the same as in any well-regulated English or Scottish city. One thing did strike me, and that was the very superior type of native one saw. The Zulu was much in evidence, and he is really a prince among Kaffirs. During the day we visited a number of shops, had a ride out into the country in jinricshaws, lunched again at the Marine Hotel, went to the Customs for our new schedules, and then I, feeling downright fagged and ill with the heat, went back to the car and to bed-minus dinner.

April 24. Trip to Zululand.

We left Durban at 7.I5 this morning for Ginginhlovu, the station from which we shall proceed by road to Eshowe, the capital of Zululand. As I was still feeling very unfit, I made up my mind to rest in my berth all day, so that I might be able to go with the 6 
78 Diary of a Tour in South Africa.

others to Eshowe to-morrow, and, although we were passing through interesting country all the day, I missed nothing, as we returned by the same route to Durban. We reached Ginginhlovu in the late afternoon, and found it a very hot spot, swarming with mosquitos and I should think every other known kind of African insect pest. This place is seven miles from the coast, and appears to be at sea level, or below it. We tucked our mosquito curtains very carefully round us that night.

Miles for the day, ninety; and from Cape Town, 2,422.

April 25. Sunday. Trip to Eshowe.

This morning we were early afoot, at least early for us ; and at 8.30 left in the post cart,a covered four-wheeled conveyance drawn by eight mules, which were changed three times en route, although the distance is only sixteen miles, which gives one an idea of the 
STARTING FROM GINGINHLOVU FOR ESHOWE. 


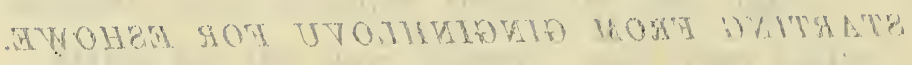




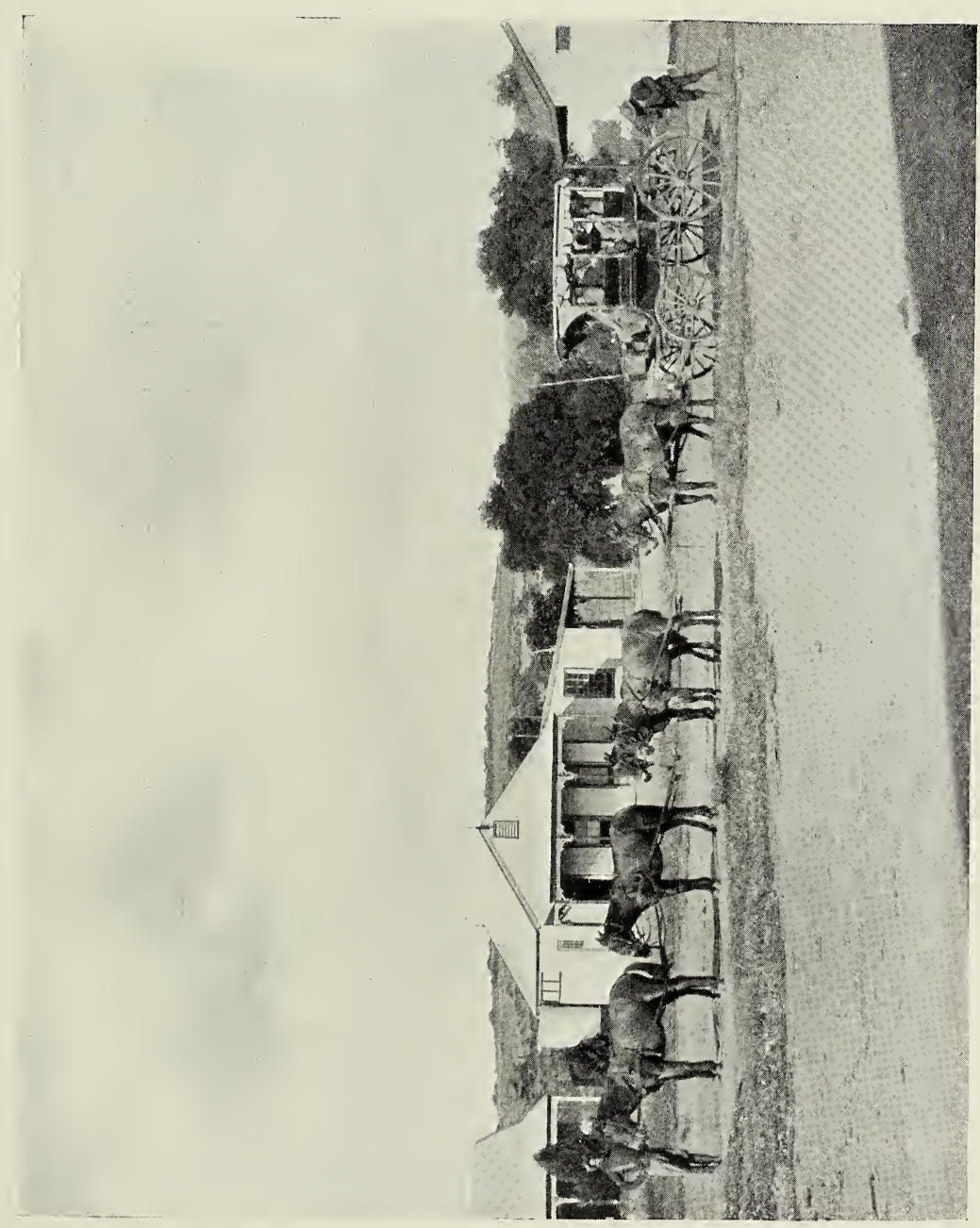



Diary of a Tour in South Africa. 79

country to be traversed. The surface was quite good when we reached the new road which had been recently made, but at the beginning of the drive, at a point where our driver, a half-breed of some kind, took us a short cut by the old road to join the new, four of our mules decided for the former, and the other four for the latter, with the result that our caravan was hauled off the road altogether, and being at a very dangerous angle, for some moments narrowly escaped a capsize. This escapade being however safely passed, we proceeded on our way, taking rather more than three hours to negotiate the sixteen miles. We all agreed that we had never had such a noisy drive, as from the moment of our starting till the arrival at our destination, our half-breed coachman never for one moment ceased to address remarks in, I suppose, Kaffir-Dutch in a terrific voice to his team.

The whole of the district we passed through 
80 Diary of a Tour in South Africa.

was most beautiful, the scene of many a bloody conflict in the Zulu wars, not to be imagined under to-day's charmingly peaceful appearance. During the morning we passed numbers of Zulu kraals, and many stalwart Zulus, all of whom, now that it is forbidden to carry the assegai, carry a stick of similar proportions. The Zulus we passed on the road invariably greeted us with smiling faces, and when they wore any covering on the head, they raised it to us. Near one of the kraals we passed, we heard sounds of great laughter and fun, and saw dusky forms flitting about in the Bush. The Laird, ever anxious for information, appealed to our loquacious half-breed Jehu as to the cause of the merriment, and received from him the laconic reply, "Oh! it's only the young ones courtin'," which seems to prove that that form of Sunday afternoon diversion is quite popular in other places besides "Merrie England" and "Bonnie Scotland." 
ESHOWE, THE CAPITAL OF ZULULAND. 


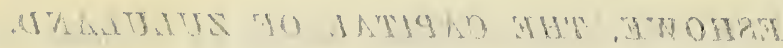



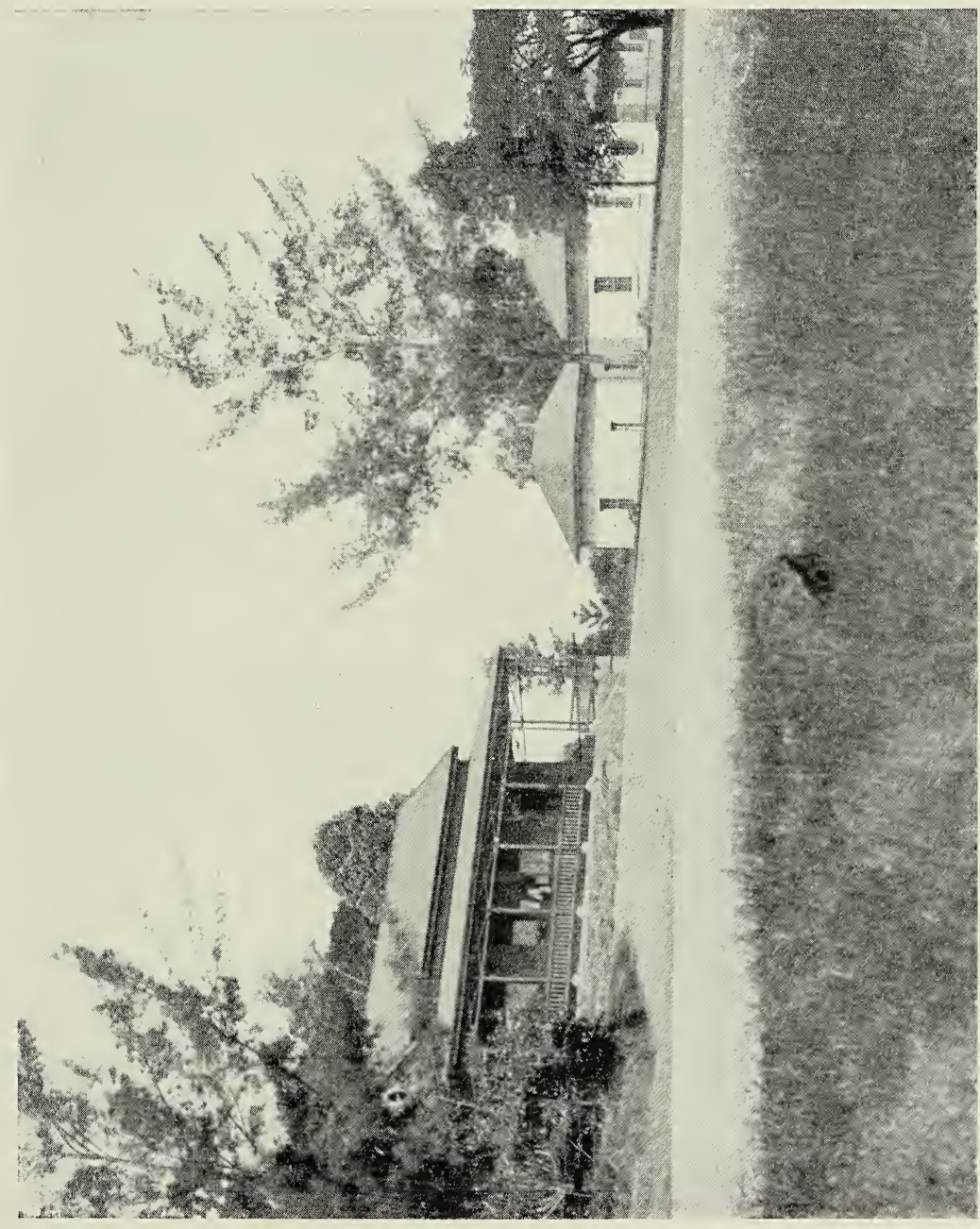

Diary of a Tour in South Africa. 8I

I rather think that our expectation of the capital of Zululand was, that it was the site of some very extensive kraal, about which the retired-from-business proud $Z$ ulu warrior would grandly stalk, followed by the admiring glances of swarthy beauties, and of forest groves swarming with dusky maidens, judging by the numbers we had seen during our journey north. Instead of which, we arrived at a most highly respectable village, that might easily have been in Hampshire, and the forest round about it a part of the New Forest in the same county. There were not many houses, but they were all well built, and stood in their own grounds with nice entrance gates, and their red roofs gave the whole picture a very home-like look. 'Tis true the red roofs were not tiles, but corrugated iron painted red, and the fact that the Eshowe Hotel was built mainly of the same material rather gave the Hampshire idea away. Of Zulus we saw none, ex- 
82 Diary of a Tour in South Africa.

cepting the local policeman, whose photograph I took, and he, proud warrior of other days, was smilingly grateful for the "tikkie" (3d.) with which I rewarded him after the operation.

The most noteworthy building we saw was the Police Barracks and Gaol, constructed to serve as a fort in the event of native trouble.

On our arrival we had a fairly long walk in the forest, a relative of the hotel owner acting as guide; then we had lunch, after which the intense heat induced a short nap, followed by a very pleasant drive back to our car in the cool of the evening, where we were gladly welcomed by our Ginginhlovu winged insect terrors. The atmosphere of our dining-room that night was something to be remembered. It was heavy with damp heat, about which flitted weird mysterious shapes, emitting uncanny sounds. We were not slow in seeking the shelter of our mosquito curtains, 
and I for one, took special precautions to make sure that I was quite alone inside them.

April 26.

Since we left Durban we have heard rumours of a probable strike on the Natal railways, and fervently hoped that we might not be stranded here. It was with feelings of great satisfaction that we steamed away from Ginginhlovu, and its winged terrors, at the scheduled time, ro.40 this morning, duly arriving at Durban at five o'clock this afternoon. We find that the strike is at present confined to the mechanics employed in the railway works, but it is said that the engine-drivers, stokers, and guards are coming out in the morning, which is a bright look-out for us, as we want to be off to the Transvaal. We are having to-night, I hope, our last dose of this goods-yard Inferno. 
84 Diary of a Tour in South Africa.

Miles travelled to-day, ninety; and from Cape Town, 2,5I2.

April 27.

This morning we heard that the worst had happened, and that engine-drivers and stokers had joined the ranks of the strikers; but strike notwithstanding, we left Durban soon after nine, only a few minutes late. Until a very short time before leaving, the stationmaster was uncertain as to whether an engine would be forthcoming or not. At the last moment one was attached, and we found out that it was to be both driven and stoked by a foreman, who certainly had not taken on a light job as far as stoking was concerned, as in the first sixty miles the line rises to rather more than 3,000 feet at Thornville Junction, from whence it descends to Pietermaritzburg-2,225 feetbeautifully situated in a hollow. Maritzburg, as it is usually called, the seat of the Natal 
Diary of a Tour in South Africa. 85

Government, contains many fine buildings, of which the Parliament Buildings, Colonial Offices, and Town Hall are the most striking; particularly so the latter, which cost $f_{100,000}$ and contains a fine organ, erected at a cost of about $£$ ro,ooo. We also paid a visit to the Botanical Gardens, which are well worth seeing. We reached this place at 2.30 P.M., and as the train to which we were attached was going on to the Transvaal border, there was some question as to whether we should not make sure of getting out of Natal; but our hosts, who do not care to miss anything they have made up their minds to do, decided that we should carry out our programme, i.e., see Maritzburg, and take our chance.

Therefore, when we had done our sightseeing, it was with feelings of some uncertainty as to what would happen, that we adjourned to our happy home for dinner. No one could tell us anything definite. All the officials we 
tackled had different views as to what might happen, so all there was left for us to do was to have a good dinner as usual, and "Wait and see." However, the train came in eventually from Durban, about one and a half hours late, this time again driven by a foreman and stoked by a Tommy, and we steamed away into the night.

Durban to Maritzburg, seventy-one miles; from Cape Town, $2,5^{8} 3$ miles.

April 28.

That journey was a very rough one, the driver evidently did not know the road well, and the gradients were exceedingly steep, rising to 5,386 feet at Charlestown. From some cause or other, probably a shortage of steam, the train was constantly coming to a standstill on steep bits of the line, and after a short pause going on again with a series of horrible jerks. Soon after breakfast we were 
Diary of a Tour in South Africa. 87

skirting along the base of Majuba Hill, a good photograph of which I managed to get after one or two vain attempts, as the train was moving rather quickly, and we were rounding sharp curves. Soon after this we reached Laing's Nek, and entered the tunnel, about the only one of any length I remember in South Africa, and it is only some 700 yards. Then in a short time we arrived at Charlestown, on the Natal frontier, after which we continued our journey over the frontier into the Transvaal on the Central South African Railway, and were quite free of any anxiety as to the proceedings of the strikers in Natal. We heard afterwards that our train was the last to arrive at the Transvaal border from Natal for two or three days.

After the beautiful scenery of the latter Colony, we found the flat and uninteresting plains of this part of the Transvaal most depressing. We reached Johannesburg at 
9 P.M., two and a half hours late, and at II P.M. are still being knocked about by clumsy shunters, as they appear not yet to have made up their minds where they will anchor us for the night. It is bitterly cold in the car, and a nasty wind is blowing. Two nights ago the temperature at this hour was nearly $80^{\circ}$ at Durban, to-night it is $50^{\circ}$. We are now 5,764 feet above sea level.

Miles travelled from Maritzburg, 4II; and from Cape Town, 2,994.

April 29. Johannesburg.

After breakfast we accompanied the Laird to the Stock Exchange, where he had an appointment to meet the manager of a gold mine in the Transvaal. While we were waiting for the arrival of Mr. Nicolas, the manager, the broker, in whose office the meeting was to take place, took us into the gallery of the Exchange, and we watched the 
ROBINSON'S DEEP GOLD MINE, JOHANNESBURG. 


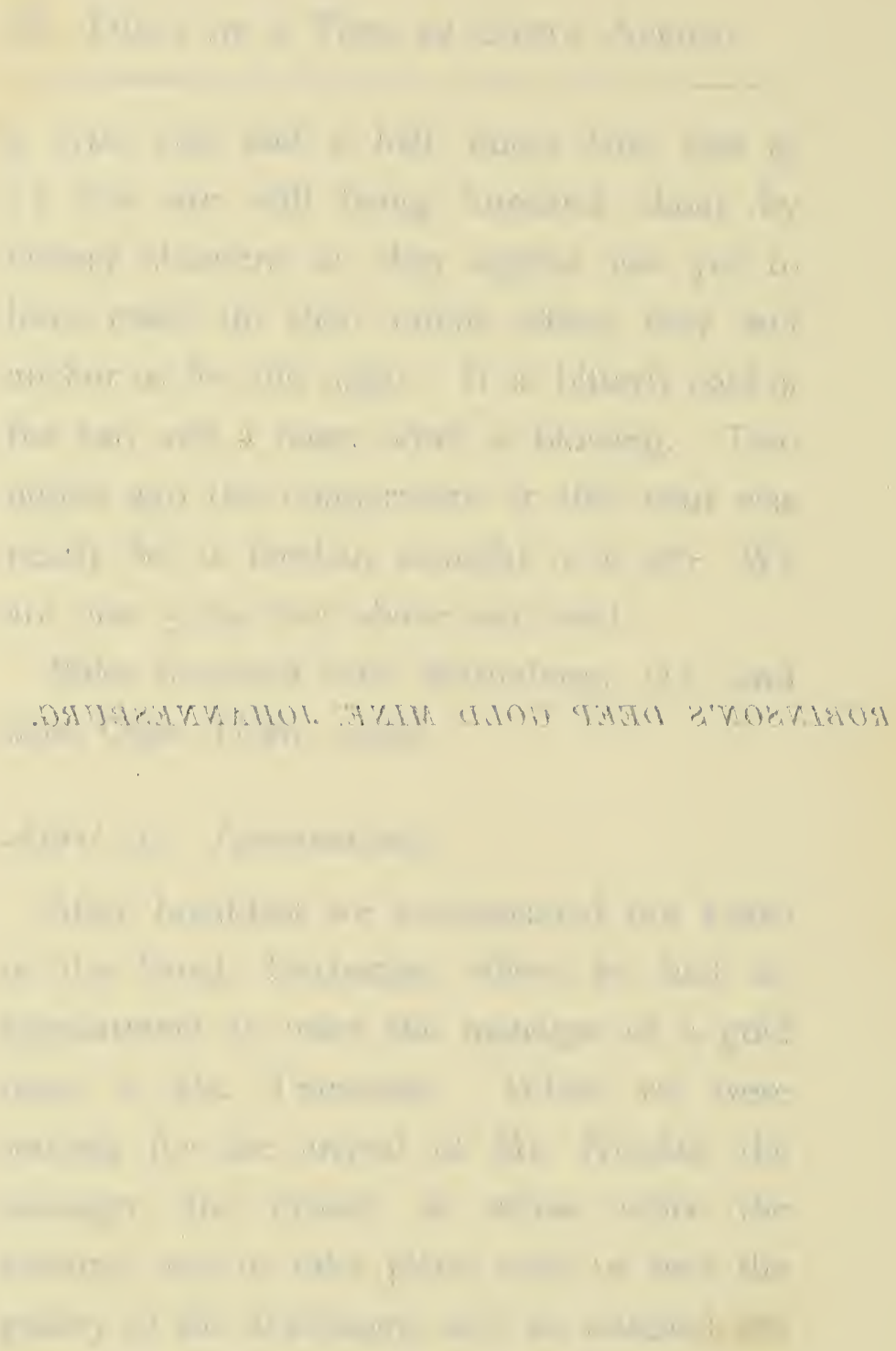




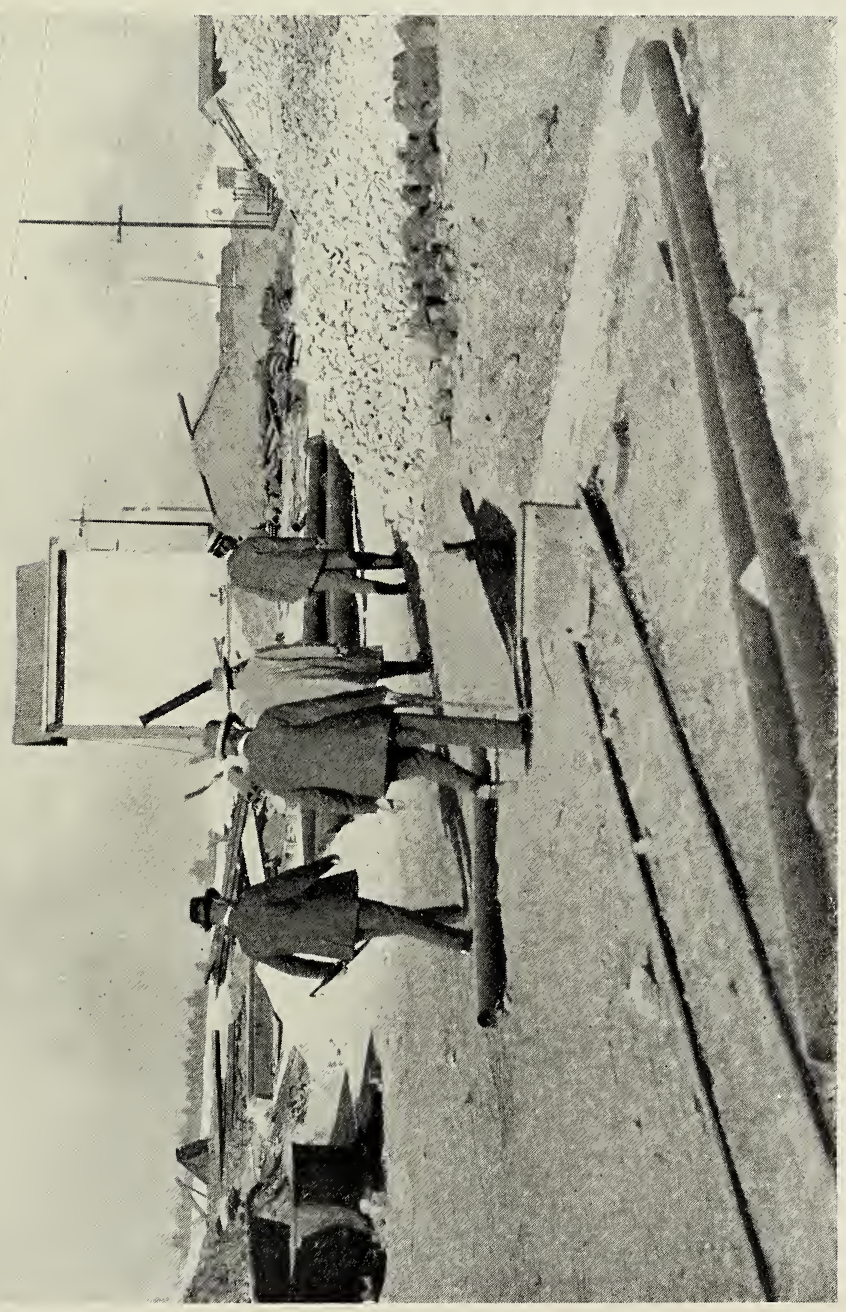



Diary of a Tour in South Africa. 89

performance below for half an hour. There was a fair amount of bellowing from the bipeds on the floor, which was all Greek to me. Our obliging friend the broker told me the technicality of the process going on. I thanked him and tried to look wise, but I was really little the better for the information, but concluded, from the great number of intelligent faces down below, that they probably knew what they were doing, and that I needn't worry.

After the Laird's interview was over, we all went to the Carlton Hotel for lunch, and afterwards drove in a couple of motors to Robinson's Deep Gold Mine, and went over all the surface works, the various processes being carefully explained to us by Mr. Nicolas, which I found much more interesting than the Stock Exchange side of the picture. After this we motored for several miles along the Witwatersrand Range, the reefs of which have 
90 Diary of a Tour in South Africa.

made Johannesburg what it is, and which extend for about I 30 miles east and west of the city. In the year I 886 , there were only a few straggling shanties along the line of reef;- -now the population of Johannesburg is about 160,000 (much the largest city of South Africa), with a rateable value of over $£ 40,000,000$.

On returning from our drive, Mr. Nicolas took us to the Rand Club for tea. In their appointments, it, and the Carlton Hotel are fit to rank with anything I have seen in London or elsewhere. Before parting with Mr. Nicolas, we arranged that he should travel with us to the Barberton district, where it was proposed to visit French Bob's Mine. It was again bitterly cold that night, and we did not move out of the car after dinner, as we were all tired after the day's sight-seeing. 
SURFACE WORKINGS, ROBINSON'S DEEP. 


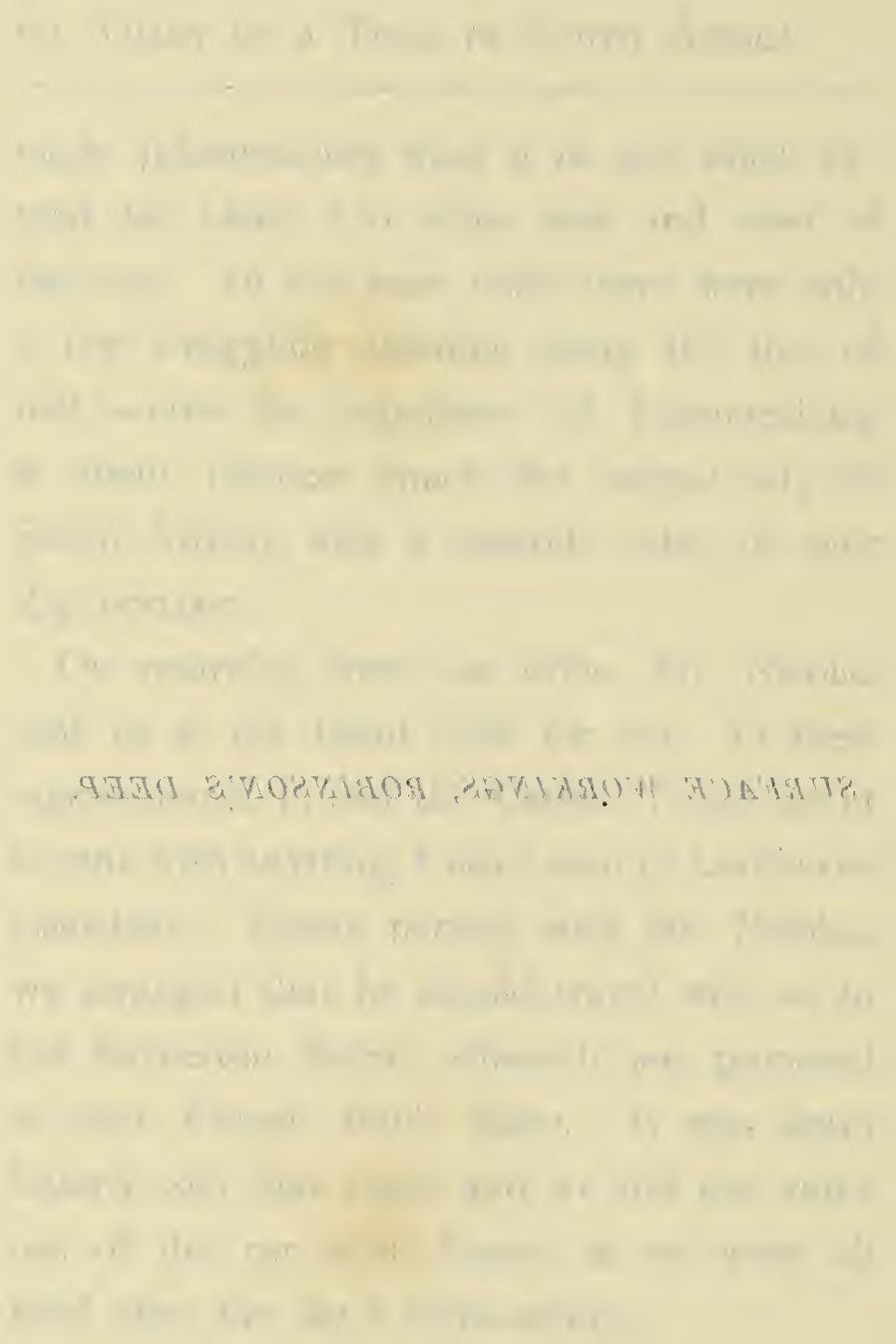




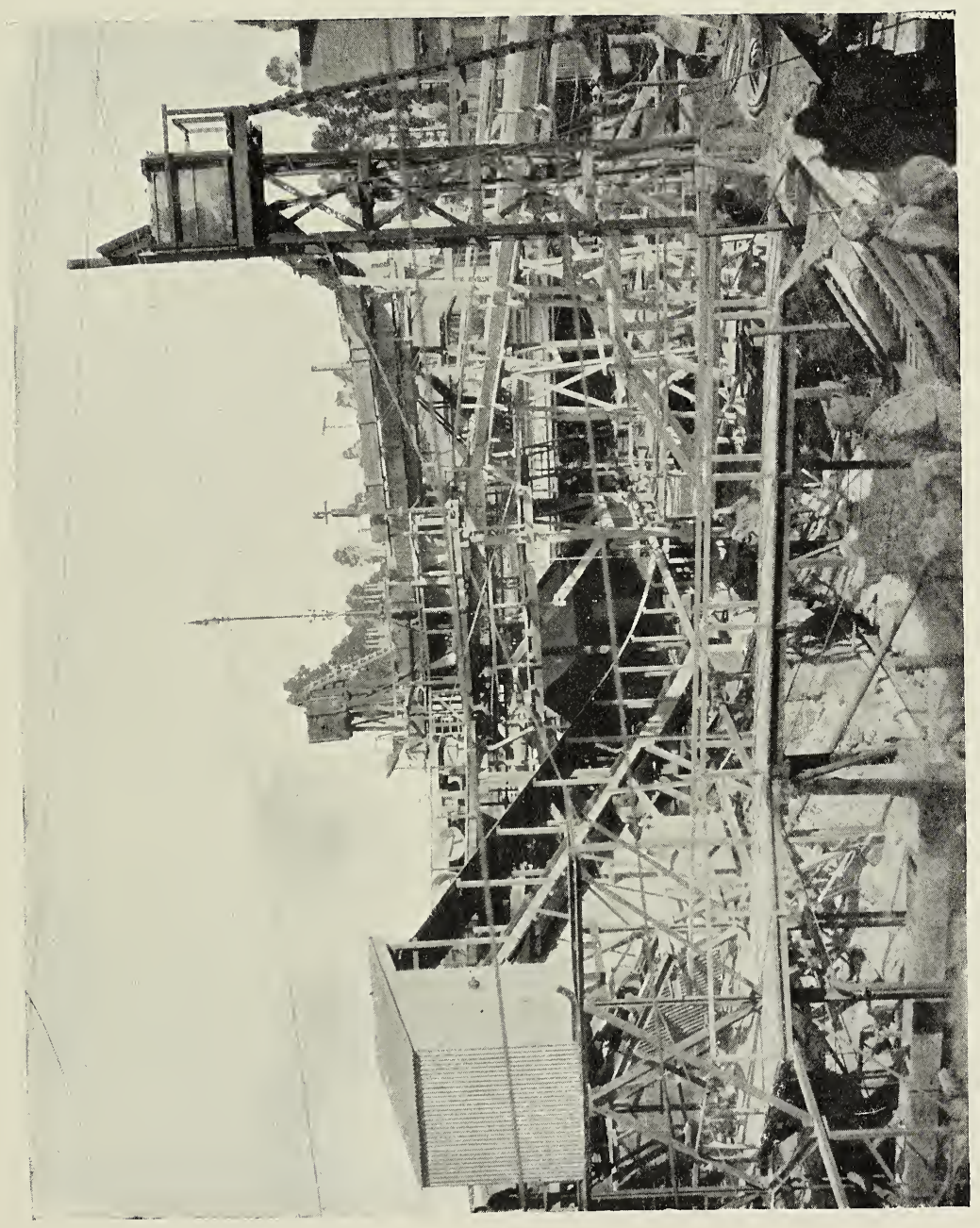



Diary of a Tour in South Africa. 9I

April 30. Pretoria.

This morning we continued our journey, leaving Joeburg, as they call it, at twelve o'clock, and reaching here at 2 P.M. Pretoria is thirty-two miles by road, and forty-five by train from the former city, I, 300 feet lower, and very much warmer. Church Square (so called on account of the Dutch Reformed Church, which formerly stood in its centre) is an extensive open space in the middle of the town, and contains some very fine public buildings, of which the Government Buildings and the Courts of Justice are the most noteworthy. Amongst others we saw, were the one-storied house of the late President Kruger, and the Dopper Church, where the would-be Monarch occasionally preached. We also saw his grave.

There being nothing else of much impor- 
92 Diary of a Tour in South Africa.

tance to see, we got back to the car in good time for dinner, and just as we had finished8 P.M. - we were coupled on to the train leaving for Delagoa Bay.

Miles from Johannesburg, forty-five; and from Cape Town, 3,039.

May I. Saturday.

The trip down this line has been of a delightful nature. When we got up this morning, we were running alongside the Crocodile River, the scenery being most magnificent. During the morning, Mr. Nicolas came into the car from another part of our train, which he had joined during the night, he having come straight from Joeburg, by the line which joins the main line from Pretoria at Witbank. He was able to point out to us many interesting things in the country we were passing through. 
CHURCH SQUARE, PRETORIA. 


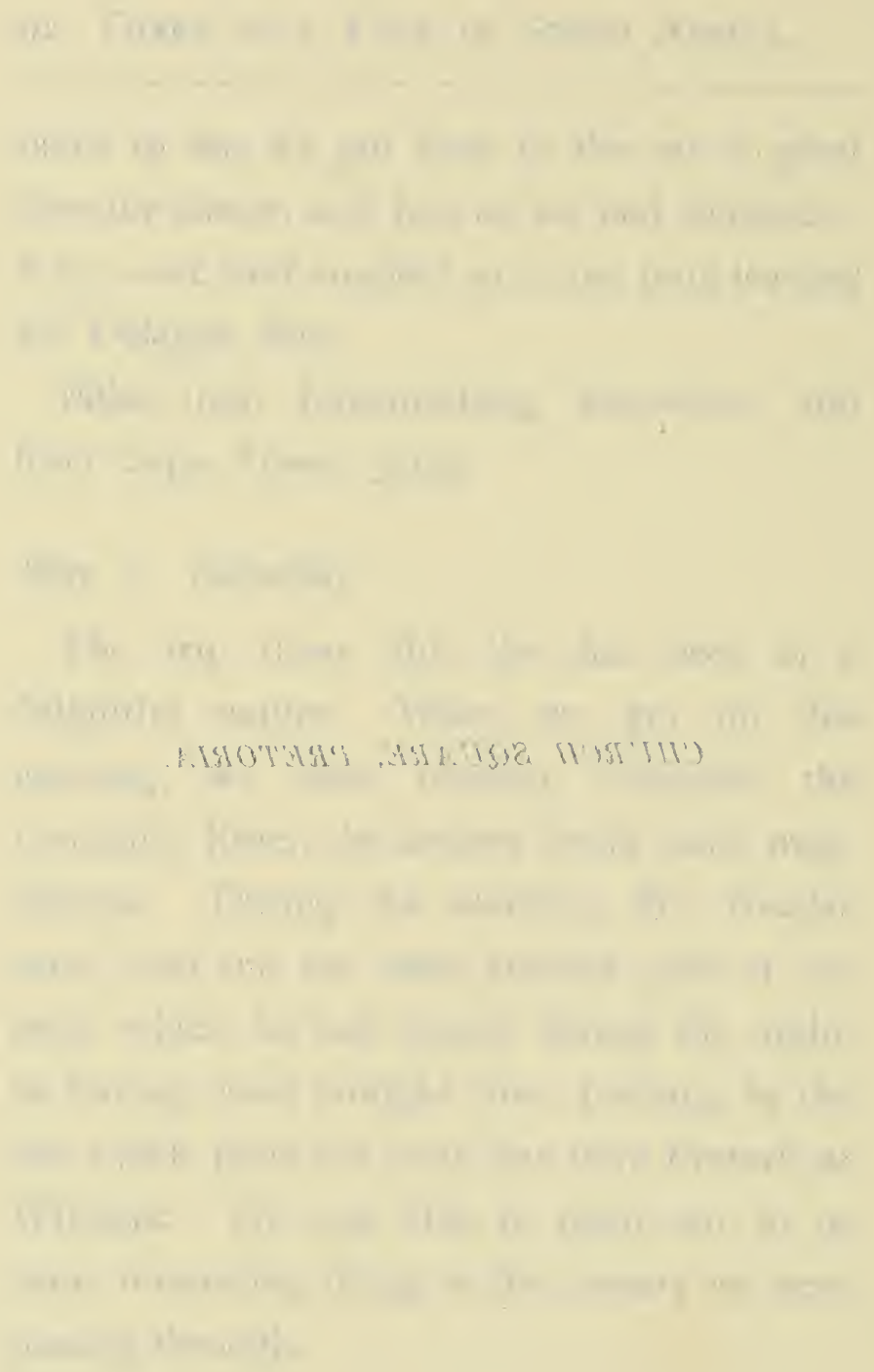




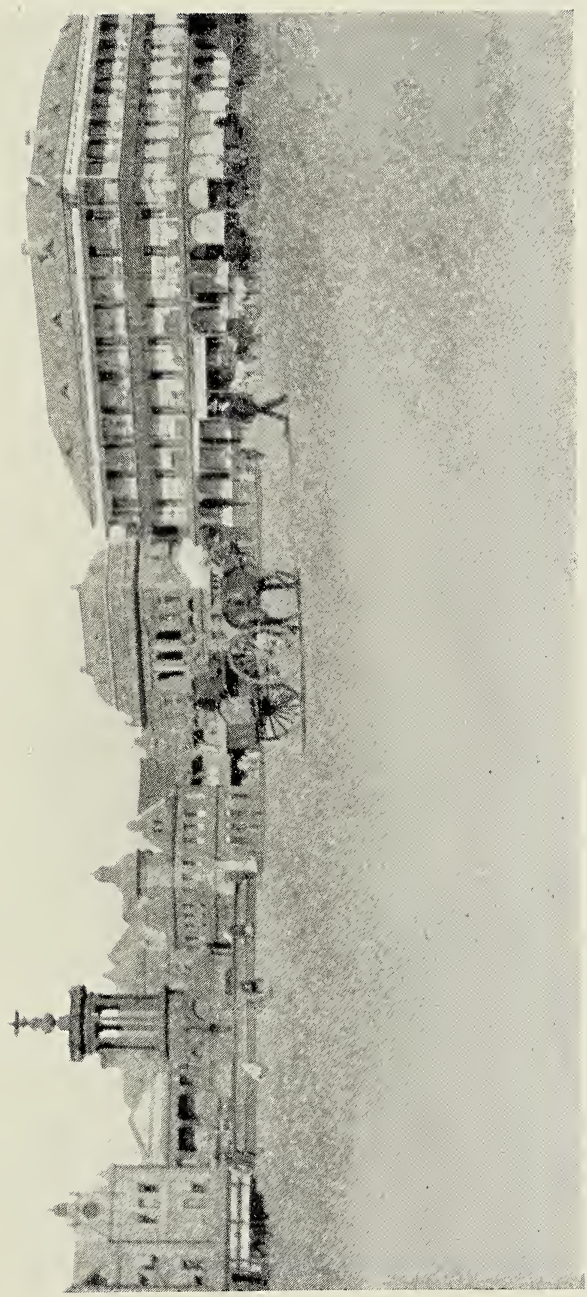



. 
Diary of a Tour in South Africa. 93

About mid-day we reached Kaapmuiden, the junction for the Barberton line, a very hot and unhealthy spot, fifty-one miles from Komati Poort, the frontier town of Portuguese East Africa. While we were waiting here to get on to the branch line, we had lunch, and just as we had begun, the shunter fiend also began, and succeeded in flinging the entire lunch off the range on to the kitchen floor, and also Mr. Nicolas, our guest, was sent sprawling on to the dining-room floor. We had a number of shunting experiences, but this certainly was the chef d'ceuvre. In this matter of shunting, the South African railways treated us about as carefully as the home railways treat coals or pig iron. Soon after this episode, we started coupled to the Barberton train, and at I. 30 P.M., reached Louws Creek, a noted district for malaria. It was only a siding, no station or porters of any description. The 
94 Diary of a Tour in South Africa.

guard uncoupled us from the train, and asked us when we would like him to call for us? There being no road from Barberton, a wagonette and four mules had been sent up by train that morning, and during the afternoon all of our party (except myself-I was not feeling very fit) drove to French Bob's, to see the works that were in course of erection. I spent the afternoon reading, until it began to get cool, and then went out for a little, and met the storekeeper of the district, who regaled me with delightful stories of the bad outbreak of malaria they had had, which was then only just beginning to abate. Shortly before dark, my travelling companions returned, and they had weird stories to tell of the breakneck track they had traversed, which I shall have pleasure in doing again with them tomorrow.

Miles from Pretoria, 258; and from Cape Town, 3,267. 
Diary of a Tour in South Africa. 95

May 2. French Bob's Mine.

After the harrowing stories I heard last night, of the frightful road to the mine, I was particularly glad to find myself feeling quite fit, and ready for anything this morning. We left camp, or rather car, which is pretty much the same thing, at 7 A.M. sharp, in the aforementioned wagonette. It was indeed a drive to be remembered, and quite indescribable. There were not only deep ruts, and dangerous slopes, which caused the vehicle to perform extraordinary sideway evolutions, but all the time we had to take care that our hands, faces, and clothes were not ripped up by "wait-a-bit" thorns, and other South African luxuries of a like nature, which swept the road at short intervals, allowing barely room for us to drive beneath. What with the frantic efforts to keep our seats, and the constant endeavour to avoid the thorns, we had a busy time of it, and it 
96 Diary of a Tour in South Africa.

could scarcely be called a restful drive, nor was it a rapid one, as we did not reach our destination till about Io o'clock. Twelve miles, I think it was, in three hours. The drive ended at the place where they were erecting the engine-house and stamps. Here we were awaited by Mr. Nicolas and an under-manager, Mr. Brown, "from Scotland," and a number of Swazis, six of whom, one a regular Sandow, were deputed to carry the Laird in a kitchen chair mounted on two long poles, up to the mine entrance above on the hillside, an ascent of fully I,200 feet. It was already very hot when we started, the sun heat in that narrow gorge being something to remember. I could have done with a rig-out of the same pattern as the Swazi boys that day, with the addition of a covering for the head. We were glad enough to protect our heads, not only with helmets, but also with white umbrellas, while those Swazis seemed to enjoy the genial rays 
Diary of a Tour in South Africa. 97

of that fierce sun striking down on their shortcropped woolly heads. It was then May, the time of year equivalent to our November:- what the heat there must be like in December and January, goodness only knows! At the top we came across first, the bungalow in which Mr. Nicolas and any other white men live. We also noticed that the huts where the Swazis were quartered, were also up there. I suppose the Swazis could have existed down in the valley during what they "call" the cool months, but we understood it was dangerous for whites to sleep there at any time of the year.

After a short rest, we went on to one of the entrances to the mine, which was on the hillside, and we were able to walk a considerable distance into it. We then returned to the bungalow, where we were shewn how gold could be obtained by hand from an apparently worthless-looking piece of quartz, by first 
pounding the quartz in a kind of mortar, and then washing it in a large flat pan until nothing was left in the pan but the bright grains of gold. By this time we were quite ready for lunch, which was most acceptable, as we had breakfasted at six o'clock. During the afternoon a war dance of the Swazis had been arranged for our diversion, at the conclusion of which they were to be rewarded with Kaffir beer. The method of regulating the quantity is quite simple. There were no mugs, or anything of that kind, but each boy was allowed to apply his mouth to the bunghole of a barrel, and his quantity was just what he could manage to extract in one operation. We noticed during their dance that they seemed to be doing a lot of unnecessary running about in the intense heat, and Mr. Nicolas told us that was simply because they wished to make themselves as thirsty as possible, before they got their chance at that beer barrel. I took a few photographs 
ENTRANCE TO FRENCH BOB'S MINE. 


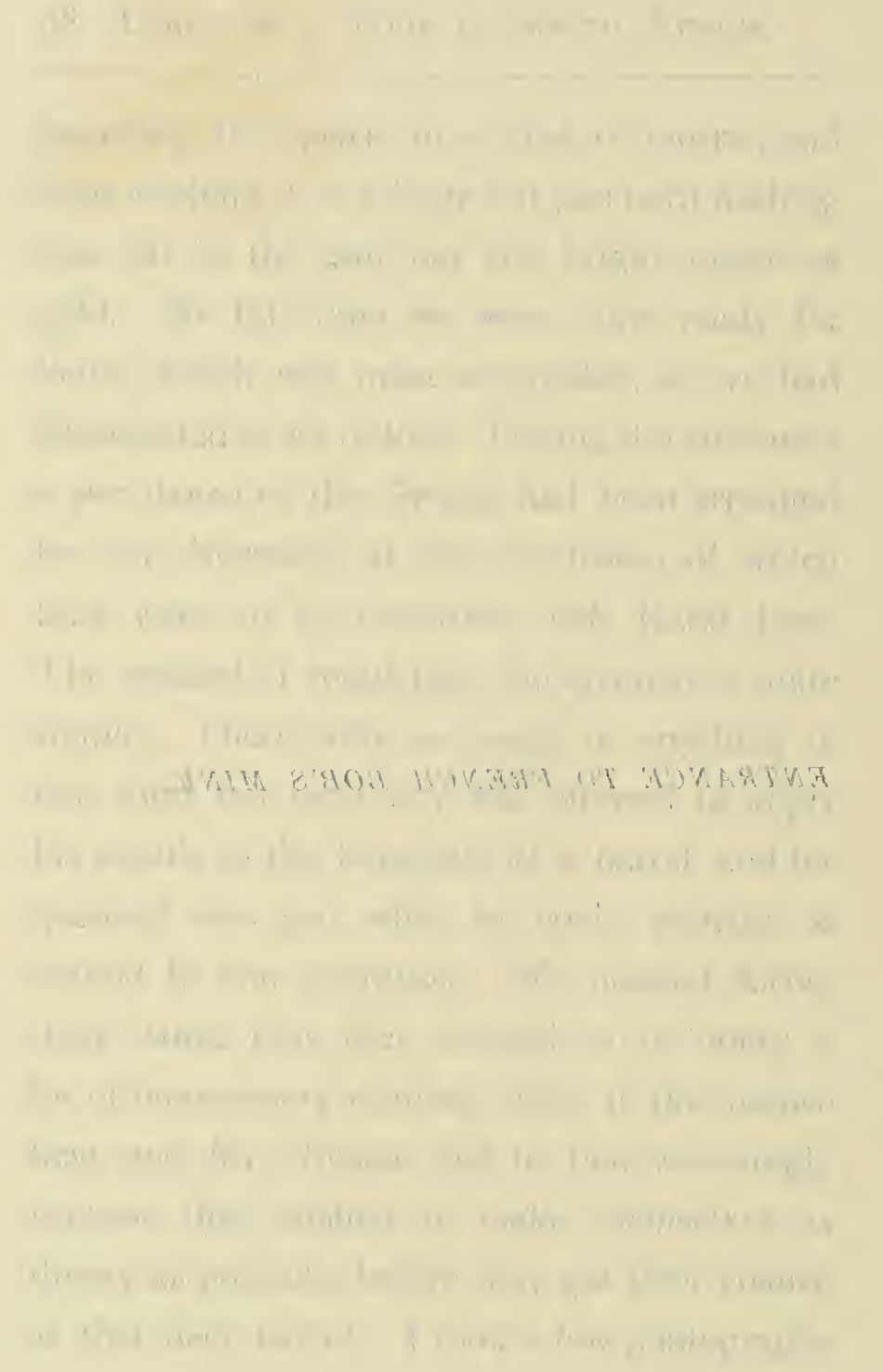




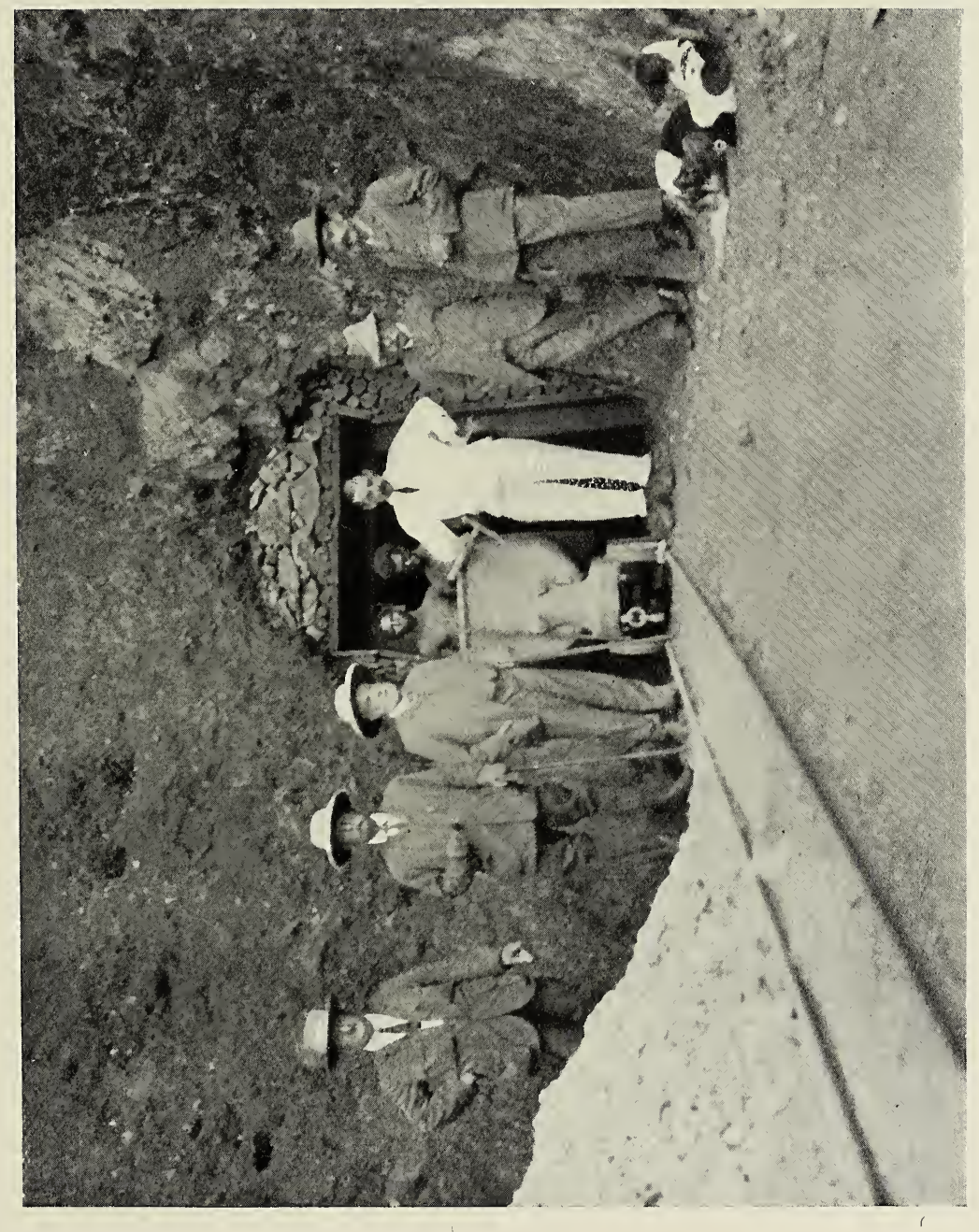



Diary of a Tour in South Africa. 99

of their war dance, which give a better idea of the proceedings than a written description.

As it was absolutely necessary that we should reach our car before dark, or else probably get our necks broken en route, we now had to descend into the valley, the Laird again in the hands of Swazi Sandow \& Co., mounted in a proper carrying-chair, brought over from the Sheba Mine, which is only a few miles distant. The Laird should have had that chair for the ascent, but it arrived too late. I took his photograph in chair No. 2, but for photographic purposes it was not nearly so effective as the kitchen chair of the ascent, which was quite a conspicuous object on the sky-line. Within a few miles of Louw's Creek, we were blocked at a ford, first by a team of sixteen oxen, which did not delay us long; they, however, were followed by a team of sixteen donkeys, hauling a waggon with far too heavy a load for them to haul up the hill 


\section{ioo Diary of a Tour in South Africa.}

from the ford, and this delayed us nearly an hour, so that it was beginning to get dark by the time we reached the car, and mighty thankful we all were to have got through the day with unbroken bones.

\section{May 3.}

After a good night's rest and a late breakfast, we are preparing to leave Louw's Creek and its Swazis. This is the Transvaal, but we are quite close to the borders of Swaziland, and most of the natives one sees about here are Swazis, who seemed to be a very good type of Kaffir, well built fellows, but smaller than the Zulu. On the opposite side of the river which runs near to us is the great Transvaal game reserve, and where there is game there appear to be always lions. The store-keeper told me that sometimes, when the river is low, one gets across, and that a couple of weeks ago one came over and during the 
WAR DANCE OF THE SWAZIS. 


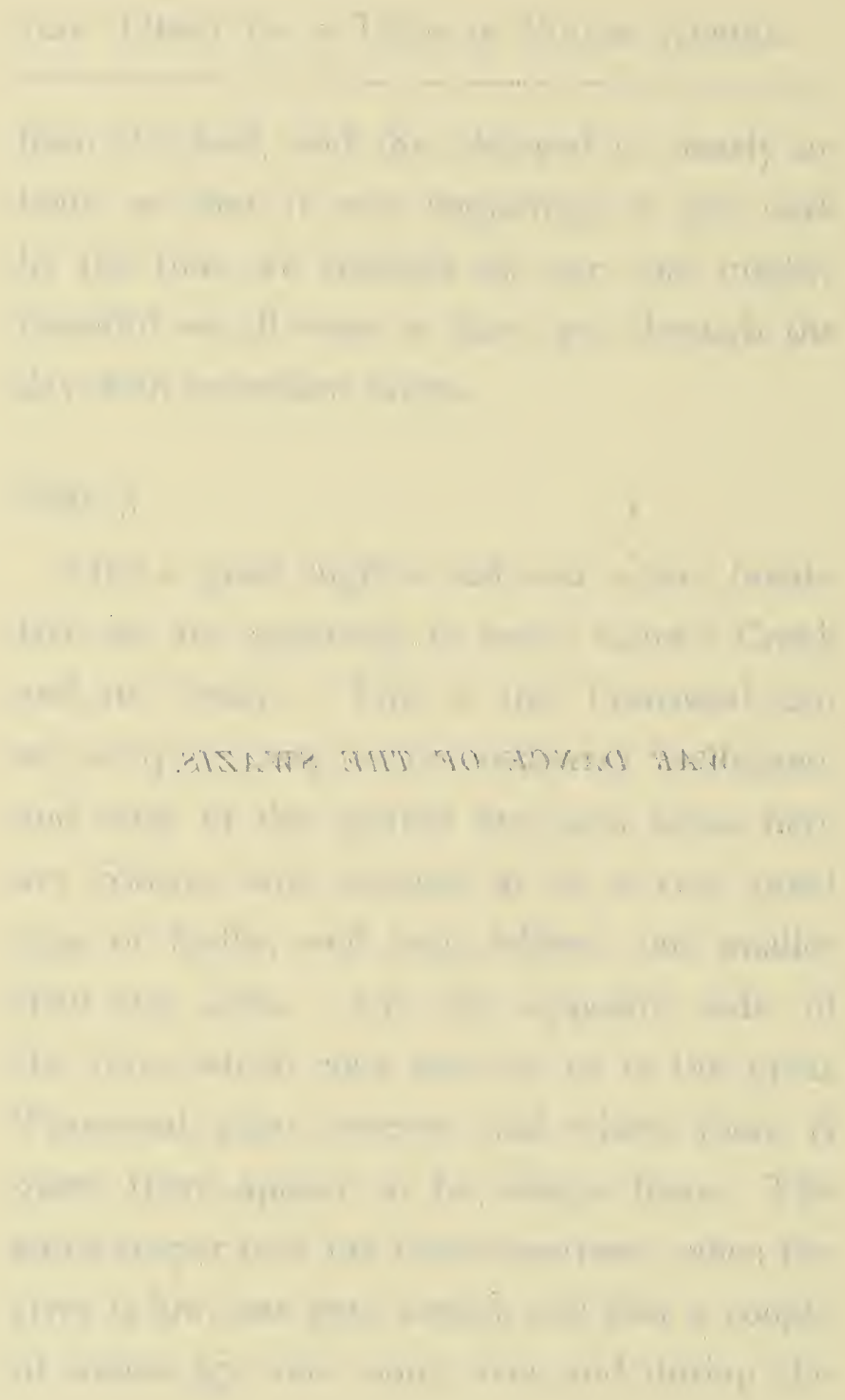




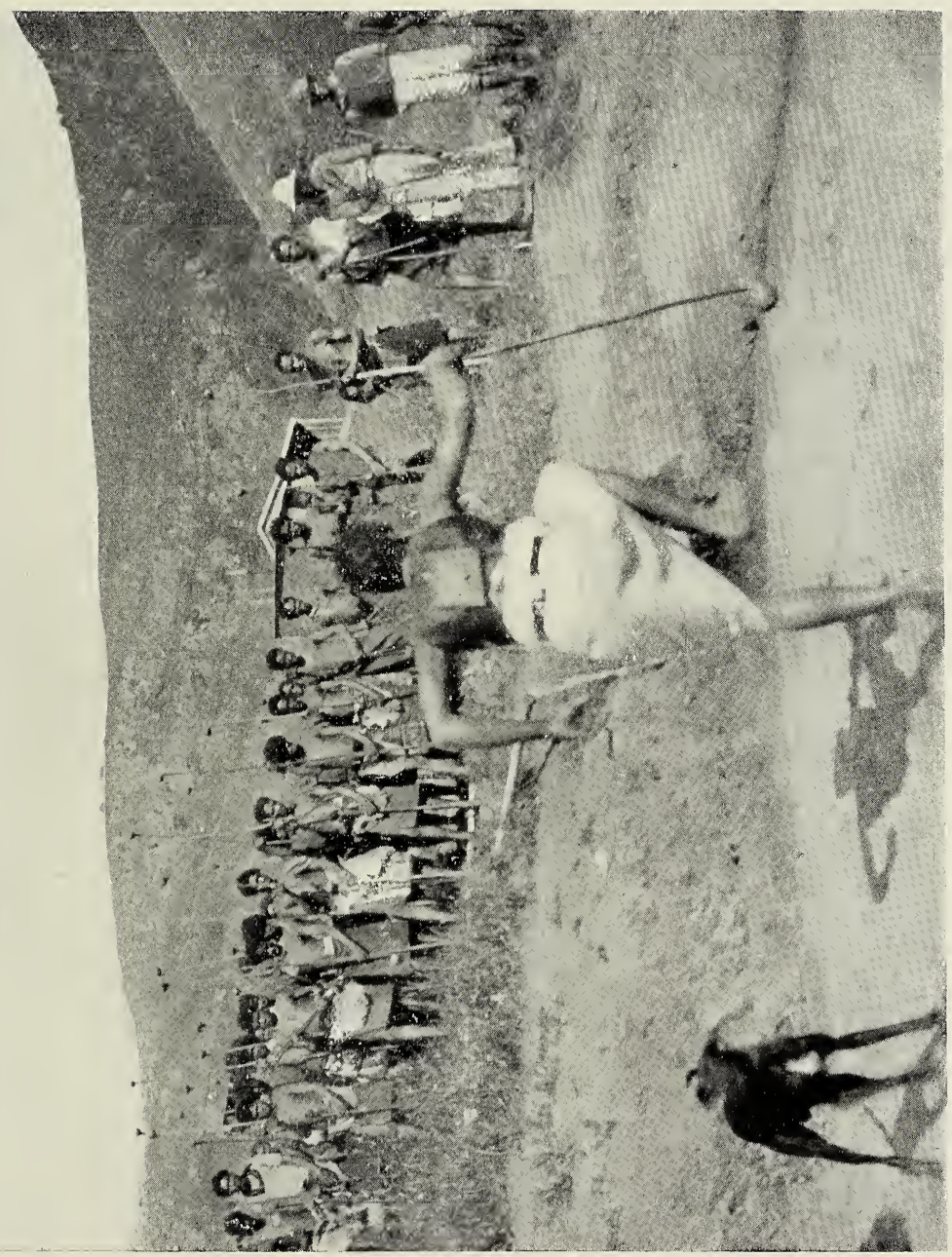



A SUAZI SIESTA. 


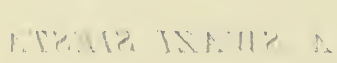




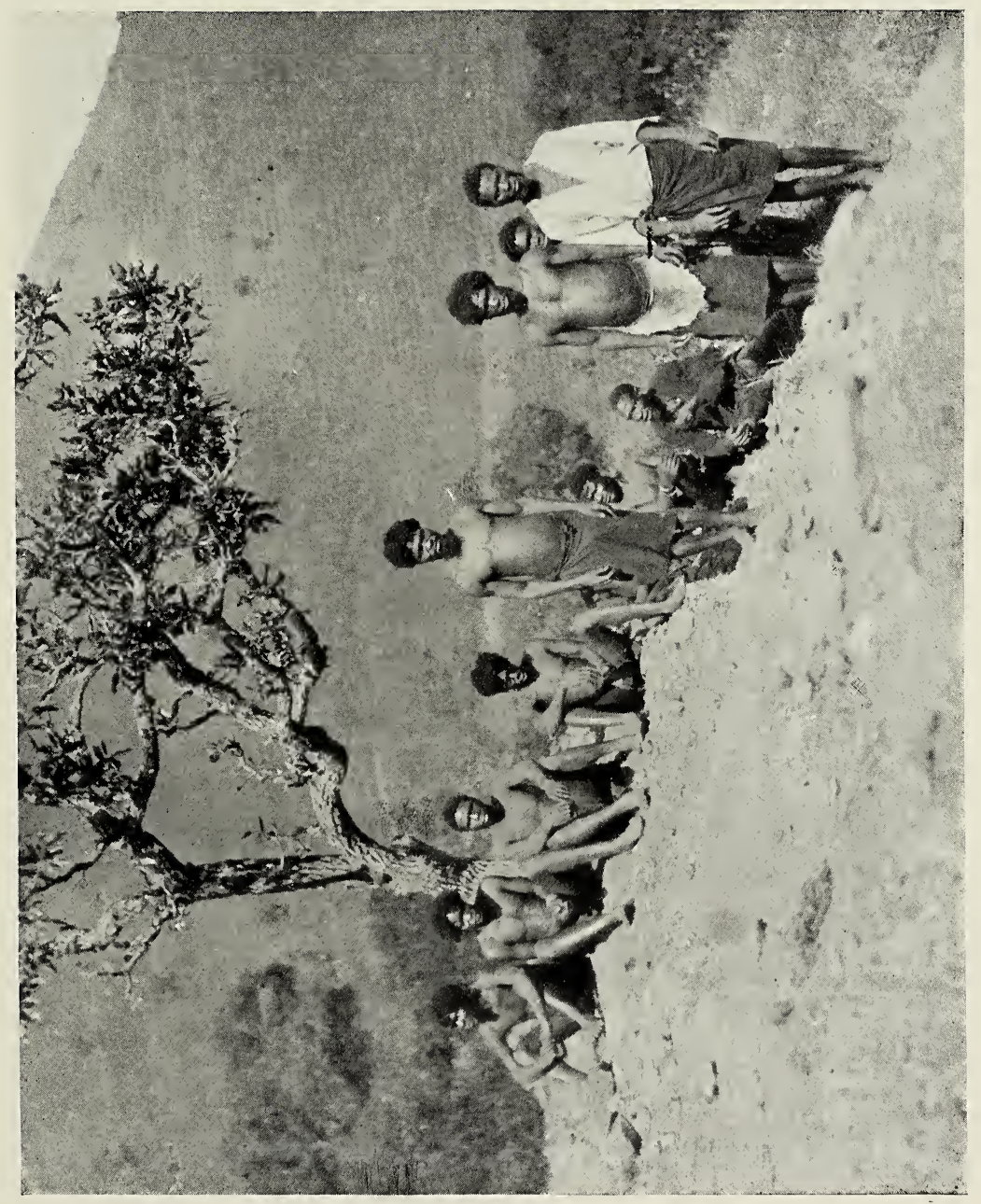



Diary of a Tour in South Africa. ioI

night killed six donkeys. Whether the prey of the lion, like the prey of the angler, increases with time I know not, but possibly had we come a few weeks later, that store-keeper might have made it sixteen donkeys! At I I A.M. our friend the guard arrived with his train from Barberton, coupled us on, and we were soon again en route for Johannesburg.

On this journey I must not omit to mention the re-passing of the Crocodile Poort some twenty miles from Kaapmuiden Junction. It is a long narrow gorge, through which the Crocodile River winds, the train following its course. Some parts of the gorge are extremely narrow, and the rocks on either side very precipitous. It is considered to be one of the finest bits of scenery in the Transvaal. We regretted very much when darkness came on in the neighbourhood of Waterval Boven, where the scenery is very beautiful. The rise of the railway up to the high veldt is very rapid 
io2 Diary of a Tour in South Africa.

after leaving Kaapmuiden, and there is a cogwheel section at Waterval Onder where the gradient is one in twenty. At Belfast, the highest point of the line, 6,557 feet is reached.

\section{May 4.}

We reached Johannesburg this morning, and have come 303 miles from Louw's Creek, and our total mileage up to the present from Cape Town is 3,570. On arrival I visited the Surveyor of Customs to get fresh schedules for Cape Colony, which we now enter again on our way to Rhodesia. We had to make a few purchases during the morning and replace the inroads on our wine cellar, caused by hot weather; then we again lunched at the Carlton Hotel, which gave one a rather trip-to-London feeling; and in the afternoon the Laird and I got on to the top of a tram-car and went out to Yoevil, an exceedingly nice residential suburb, which we were very glad to have visited, as it 
MAFEKING, FROM ROOF OF TOWN HALL. 


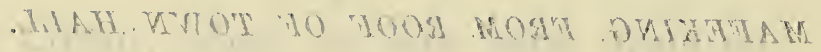

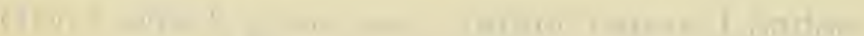

h. ', 10 


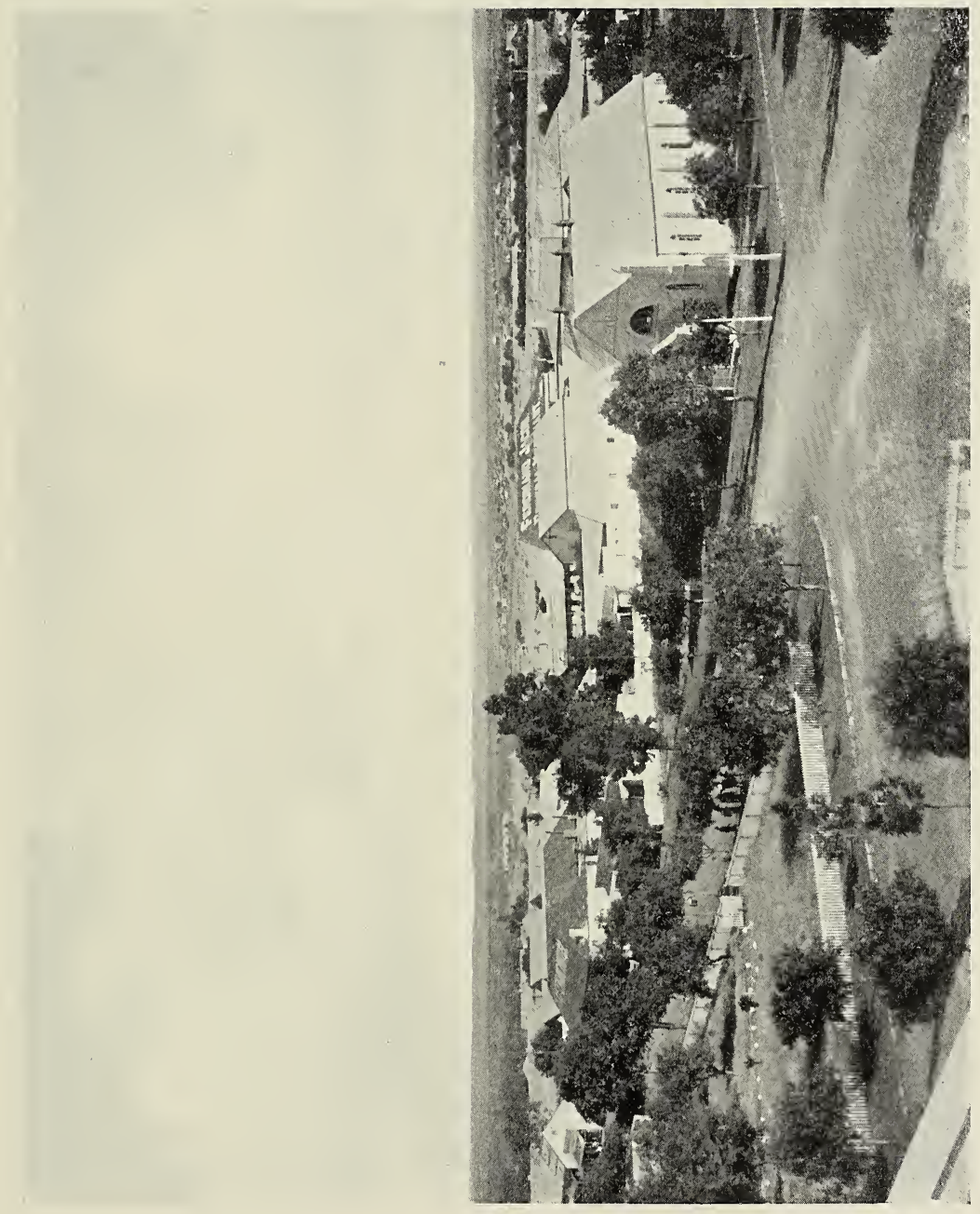



Diary of a Tour in South Africa. IO3

gave us a much more favourable impression of what life in Johannesburg really is than we had imagined previously. In the evening we went to the Empire Theatre, and saw quite a good performance of the type usually associated with a theatre of that designation.

\section{May 5.}

We left Johannesburg at Io A.M. and reached Warrenton Junction about ro P.M., at which place our car was coupled on to the train coming from Cape Town to Mafeking.

\section{May 6.}

We arrived at Mafeking at nine o'clock this morning, having travelled 436 miles from Johannesburg, and a total of 4,006 miles since leaving Cape Town. We were met by Major Cowan, well known as the leader of Cowan's Horse in the late war, and who had played an important part in the defence of the town. 
io4 Diary of a Tour in South Africa.

We owed this local assistance to our medical professor, who had arranged this meeting before we left England. Major Cowan promised to come for us soon after we had had breakfast, and shew us the sights of the town, and also the points made memorable during its defence. By ten o'clock we had started in two Cape carts, in the company of Major Cowan and a lawyer friend of his, the owner of one of the carts, and we were able with such efficient guidance to make a thorough inspection of the defences of the siege, of which probably Game Tree Hill was one of the most notable points, and the Brickfields another. Our guide, Major Cowan, had a pretty hot time in the former, where he had lost several of his chums.

What impressed one most, was, I think, the absolute flatness of the entire district, which, from a civilian's point of view, made it look an impossible place to defend, and indeed, from all we heard, it could not have been defended 
Diary of a Tour in South Africa. 105

from any well organized attack. From all accounts the slim Boer was too anxious to save his own skin, and disliked to do much in the attacking line. Major Cowan spoke very highly of the defence and the defenders, but expressed his regret that the stoppage of the Relief Column to have its photograph taken, allowed the Boers to get away with practically the whole of their stores and baggage. We went to Dickson's Hotel for lunch, after which we visited the Town Hall, Drill Hall and Club, and then having made arrangements for some shooting for the next few days, we went back to our car for dinner, bridge, and bed.

\section{May 7.}

This morning, by arrangement with the Mafeking station-master, we had a special engine to take the car out to Cowan's Post, ten miles out on the veldt, not far from Major Cowan's house. Here we were met by our 
io6 Diary of a Tour in South Africa.

friend, who advised us to go on to Buurman's Drift, about a mile further on, the terminus of this branch line. It was the queerest railway terminus I have ever seen. The railway building consisted of a queer-looking shanty, and there were no officials. The scenery consisted mainly of a barbed wire fence separating Cape Colony from the Transvaal. Close to the station was a gate in the fence, and near the gate were some tents, in which dwelt several men, who combined the duties of police and custom-house. They had two or three horses tethered near the tents, and their chief duties were to examine anything that passed through that gate, and patrol the barbed wire fence for a good many miles day and night. There seemed to be a few houses, a sort of hamlet, about a mile away on the Transvaal side of the fence, and all the rest of the scenery was grass and bush, stretching away in every direction to the horizon, a vast 
Diary of a Tour in South Africa. io7

silent scene, the solitude of which during the day was only broken by the buzz of innumerable insects, and the harsh croak of the koorhaan, and at night by the cries of birds strange to us, and the distant bark of a jackal. Shortly after the engine-driver and stoker, in the absence of other officials, had deposited us on a siding on the Transvaal side of the barbed wire fence; Major Cowan arrived with a couple of Cape carts to drive us to his house, some three or four miles distant, for lunch. It was the usual veldt drive, pretty rough and not much of a track to the unpractised eye. One thing in that drive impressed itself upon me, and that was the crossing of a ford with a very rocky bottom, and so deep that the water came into the floor of the carts. Our friend the Major, said he had done it in the dark; for my own part, I was exceedingly glad when we had done the return journey shortly before dark;-I had no great desire to do it again 
io8 Diary of a Tour in South Africa.

even in daylight, and I rather think this was the feeling, though unexpressed, of our party.

Our reception at Major Cowan's house (a very comfortable homestead,) was a most pleasant one. Mrs. Cowan, a native of Ayrshire if I remember rightly, made us very welcome. She had two nice little children, and a Scotch maid. This, coupled with the fact that there were scones on the table, gave one a distinctly home-like feeling, and almost made one forget that one was out on the African veldt. They gave us a very nice lunch, the principal item of which was buck, of what particular kind I shall not commit myself to say. After lunch, we went out on the veldt for a couple of hours in the hope of getting a shot at something; but as the heat of the afternoon was excessive, and nothing was to be seen in the way of game, except a solitary buck we wakened from an afternoon nap, and whose presence we were only aware of from the rustle and swaying of 
Diary of a Tour in South Africa. iog

the long grass in front of us, we were glad enough to seek the friendly shelter of our host's house. Having had tea and discussed plans for the next day, we started on our return journey; but although we only had a few miles to go, it was pitch dark before we reached our car, there not being very much twilight in these regions.

Miles from Mafeking, ten; and miles travelled from Cape Town, 4,016.

\section{May 8.}

Before we got up this morning, we heard the splashing of heavy rain on the roof, and it has continued for some hours; the outlook generally, judged by home standards, pointing to a soaking day. However, it unexpectedly cleared up about lunch time, and in the afternoon Major Cowan drove over, and it being then too late to make any expedition, we loitered about in the neighbourhood with our guns, and shot two or three koorhaan before the darkness 
ilo Diary of a Tour in South Africa.

came on, again spending the night at our anchorage in Buurman's Drift.

\section{May 9.}

Notwithstanding a rather threatening looking morning, Major Cowan came over for us with a couple of carts, each drawn by four good mules, and to-day we have driven fully thirty miles over more or less trackless veldt. During the morning, we fell in with an old Kaffir chief (converted), named Elias, and another rather ragged individual who we concluded might be his private secretary. The chief had a gun, and they were both mounted on quite decent ponies. They stuck to our party valiantly till lunch time! having probably scented "tit bits" from afar. We did not understand a word they said, but gathered from the Major that they intended to shoot a big paauw for us, if they were presented with some cartridges. I may say in passing they got a supply of cartridges, 
SHOOTING PARTY, NEAR MAFEKING. 


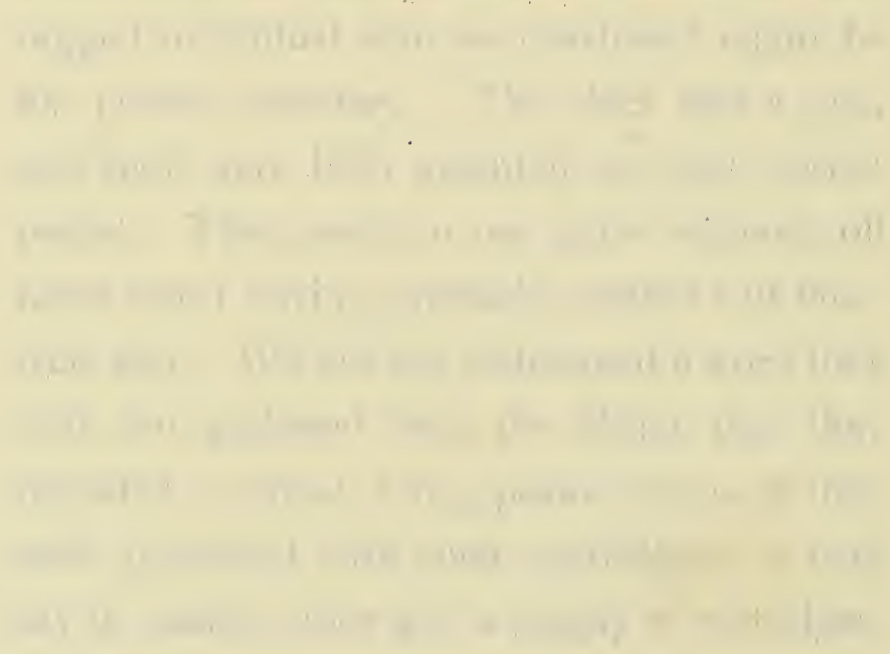




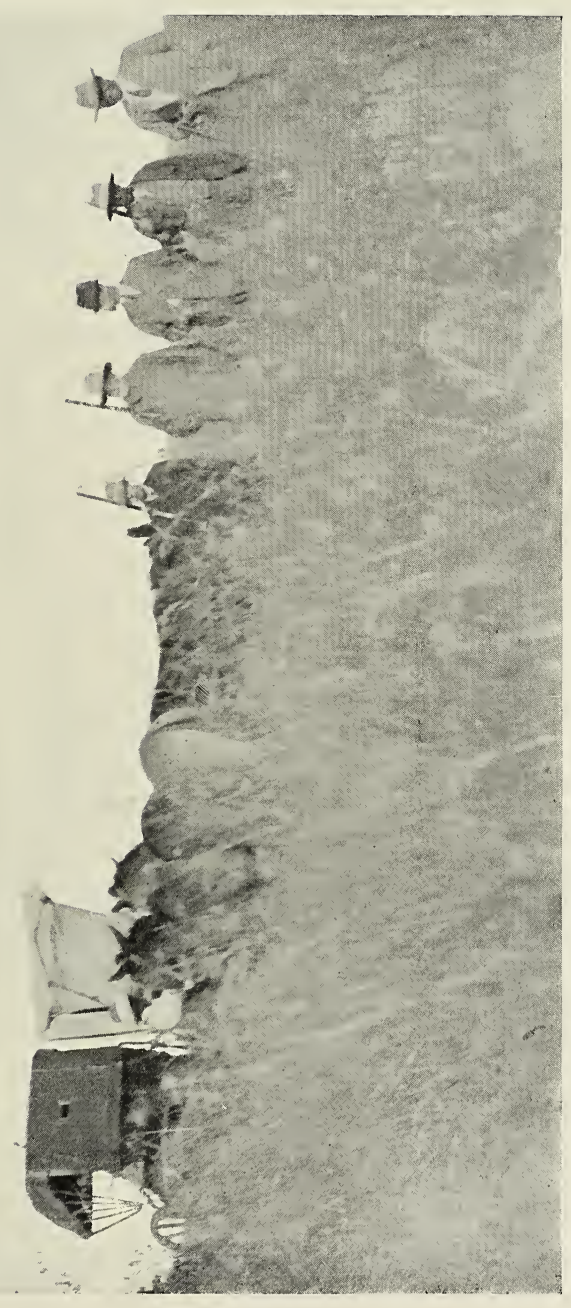



Diary of a Tour in South Africa. i i I

and if they got that paauw, they kept it. During our lunch, the Chief Elias, and his Lord Chamberlain squatted in the high grass, and then strictly according to etiquette in such matters, they lost no time in violently assaulting anything we had left in the food line, and although one is not allowed to give drink to the natives, he, being a chief, had an exception made in his favour. During the day, our party got a number of koorhaan, and a few partridges, and several shots were fired at buck without result, it being quite impossible to see them in the long grass, except for the fraction of a second. The Laird, the Major, and I had a fairly good chance at a small buck, as it came tearing down the line at a fearful speed. The Major, who was at the end of the line, thought he had hit it, but as we were shooting in Cape Colony, and the buck crossed the wire fence into Transvaal territory, we were unable to follow it. From a sportsman's point of view, 
this, and the two following days were, I suppose anything but a success; but it was a charming experience roving about in the wide and apparently boundless veldt, and none of us will readily forget the days we spent under such novel conditions. It was again dark when we reached home, and after we had wished our friend Cowan a good passage across that nasty ford in the dark, we were quite ready for dinner and bed.

May Iо.

To-day has been pretty much of a repetition of yesterday, driving in another direction; although in this flat plain round about Mafeking, different points of the compass do not count for much to the stranger, it not being easy to get a landmark. In this respect the veldt bears a strong resemblance to the sea, one having to depend mostly for one's bearings on the sun by day, and the stars at night, unless of course 
LUNCH ON THE VELDT. 


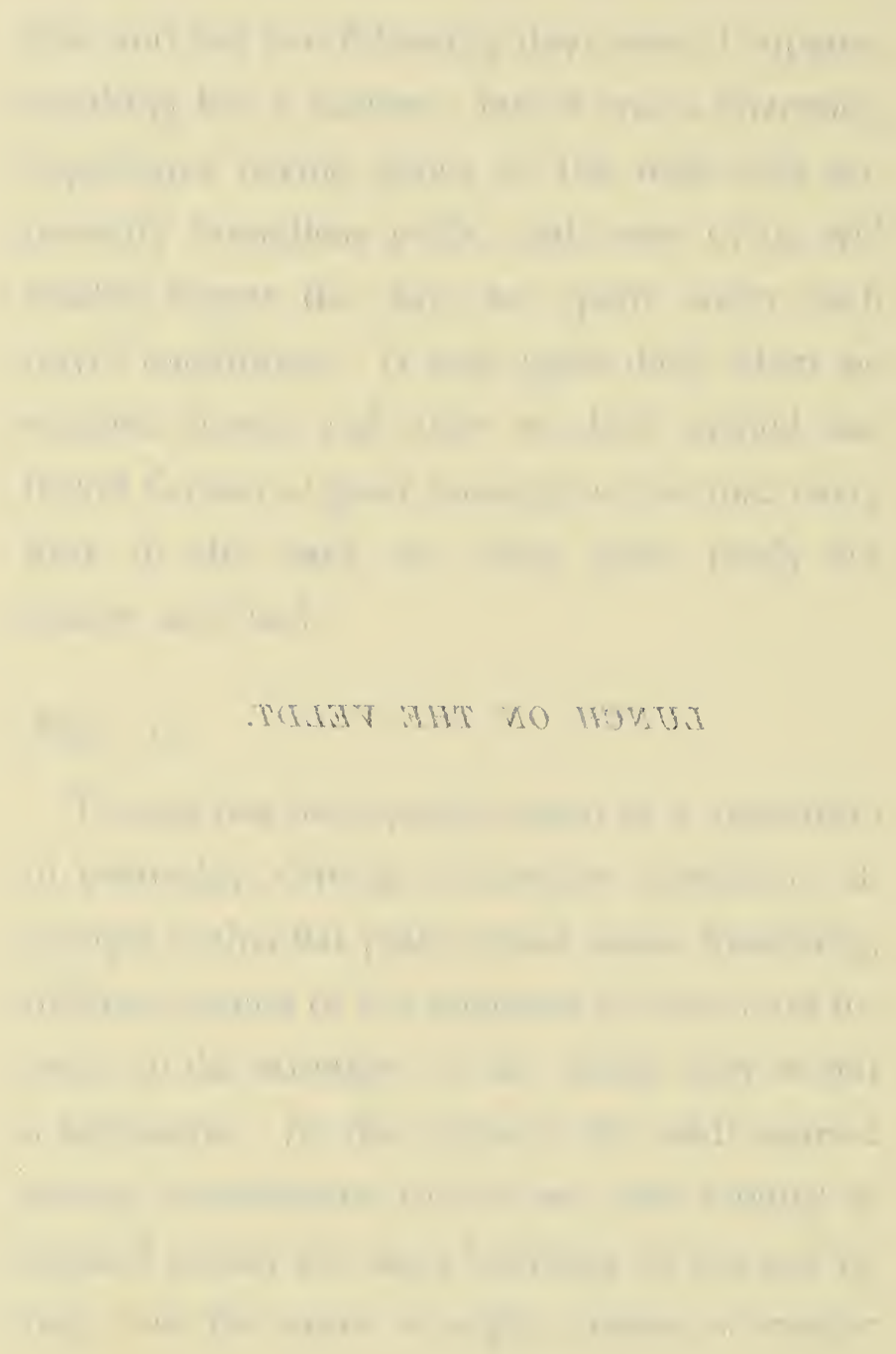




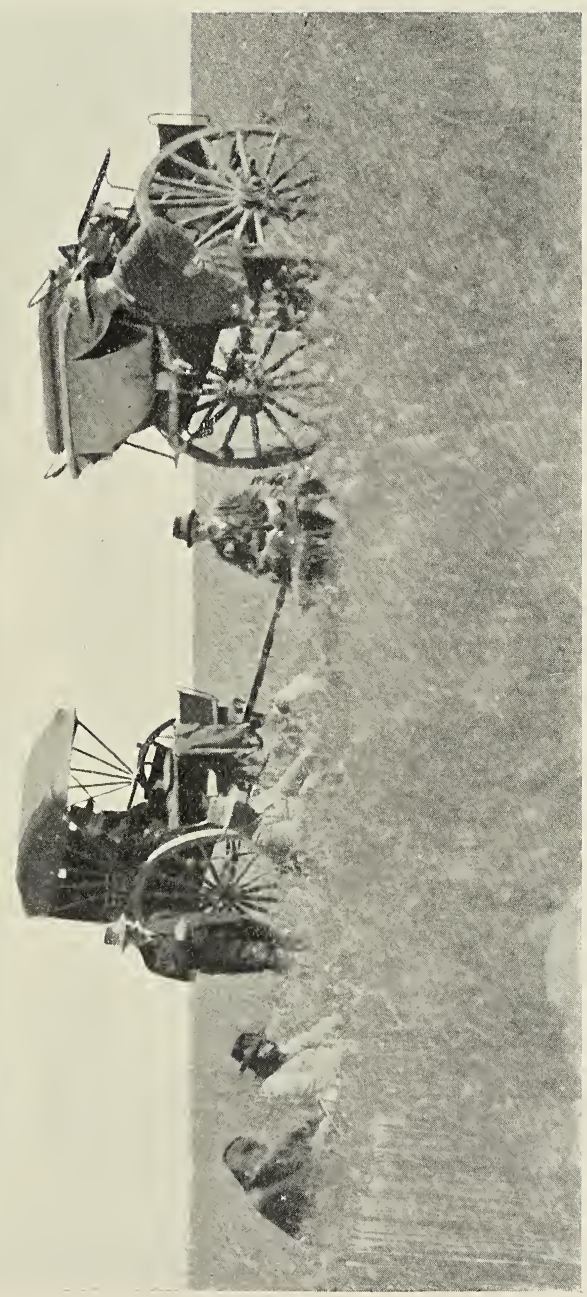



one is familiar with the district. It was this fact that gave the Boers such an advantage over our troops in the late war. To-day has been chiefly remarkable for the large number of paauw (Dutch for peacock) we have seen. The bird is really a bustard, and is next in size to the ostrich. A cock bird sometimes stands five feet in height, and weighs about forty pounds, but we heard of one that had been shot weighing sixty-five pounds, which had figured at the previous Christmas dinner in Dickson's Hotel. Our first introduction to the paauw was yesterday, when the keen eyes of the Major detected one about a quarter of a mile ahead. We made an attempt to stalk it, but unsuccessfully. It is a difficult bird to shoot, and it is almost impossible to get near it with a shot gun. Standing as it does some four to five feet in height, it has a very wide range of vision, and once in the air it flies at a great height. During to-day we saw fully 
il4 Diary of a Tour in South Africa.

twenty paauw - at one time eight in the air at once--but we did not get within range of any of them. We got a number of koorhaan, partridges, and hares, and several shots at buck, with no result. It was dark before we reached the car, the lights of which gleaming across the veldt, we were glad enough to see, as we were all pretty weary after our long day under rather a scorching sun.

\section{May II.}

We were out again this morning fairly early, the Major coming for us as usual, and I am sure we owe him a deep debt of gratitude for what he has done for us in this district. Not only has he familiarised us with Mafeking and its siege, but in these long drives and tramps over the veldt, we have got glimpses of a kind of life quite unknown to the average Briton. Undoubtedly, the African veldt has quite a charm of its own, 
and although one would not willingly change the beautiful hills and valleys of Scotland for its scorched scrub and ironstone koppies, still, in its vast immensity, one has a sense of freedom that one does not know in this milestone-ornamented land of ours. During to-day we have shot a number of koorhaan and partridges, but have seen no paauw. We joined the car at 5 P.M. at Buurman's Drift, and are now back at Mafeking, where we have got our tanks refilled with a much needed supply of water, as we have been very short of it for the past couple of days.

Miles from Buurman's Drift, ten; and since leaving Cape Town, 4,026.

May I 2.

Have spent a quiet day in Mafeking, lunching again at Dickson's Hotel, which was the head-quarters during the siege. To-night the handle of our old friend, the Plough, is 


\section{i 6 Diary of a Tour in South Africa.}

visible again in the north, just above the horizon.

\section{May I 3.}

We left Mafeking this morning at 9 for Bulawayo, and have found that the dust of this section of the line has been in no way exaggerated. Fortunately, we took the precaution to get our car put in the front part of the train, the rear of which has been almost invisible in a cloud of dust during the greater part of the day. During the afternoon, we passed the Tropic of Capricorn; and as our course is still about 600 miles to the north, we shall have, I suppose, from two to three weeks of the Tropics, as our intention is to go to the present railhead, which is at Broken Hill in Barotse Country. During the whole day we have been passing along the fringe of the Kalahari Desert, which still teems with large game, but is a very difficult country for 
BULAWAYO-RHODES'S STATUE. 



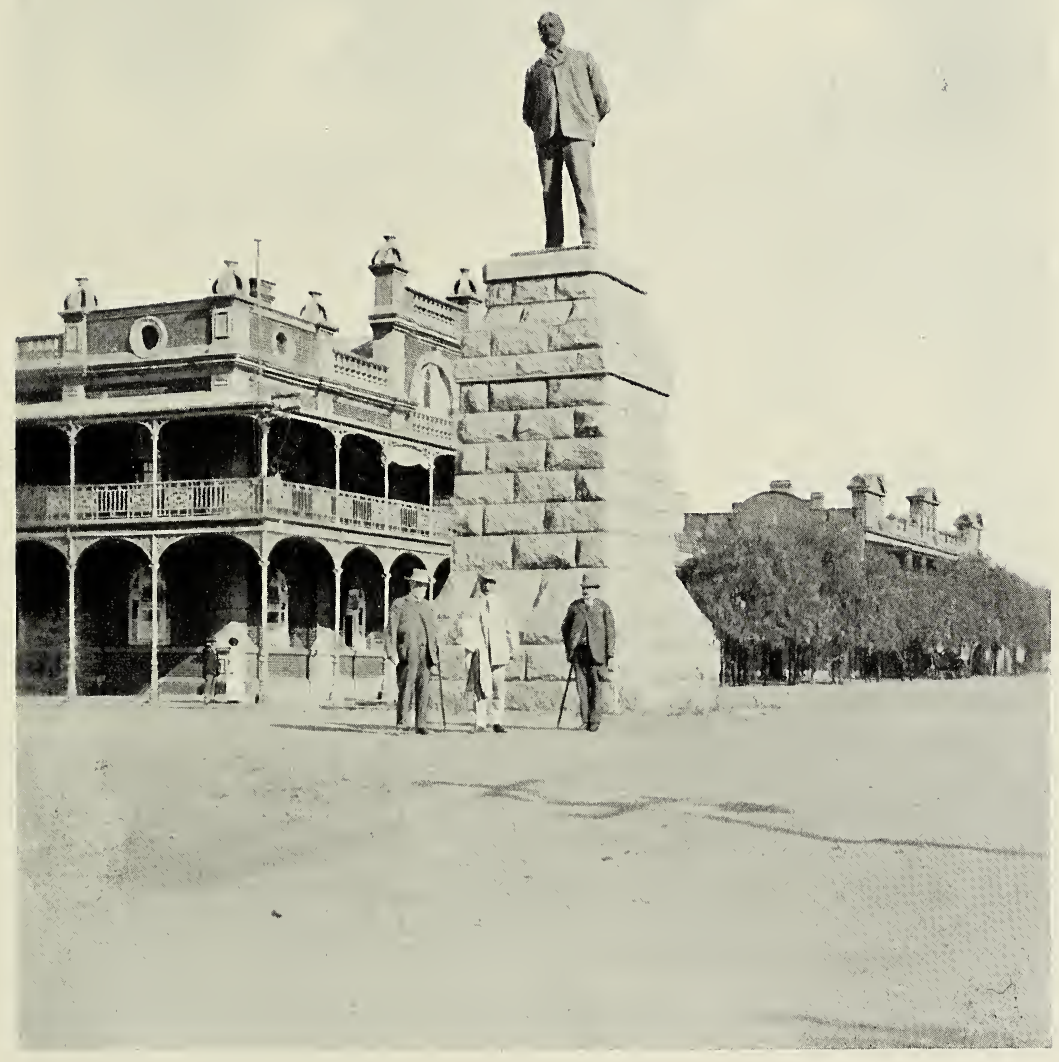



THE DAM-MOTOPPO HILLS. 


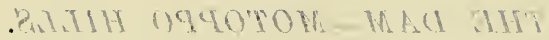




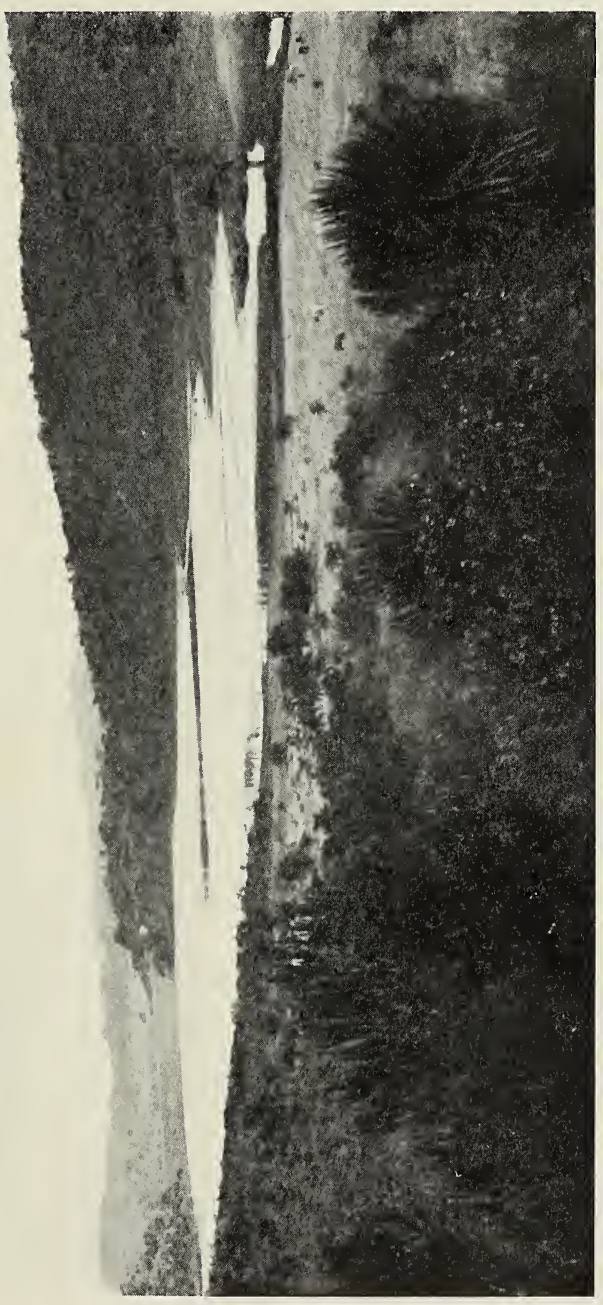



the traveller, owing to the uncertainty as to where water is to be found. We have seen nothing during the entire day but bush-covered desert, and are still grinding along to the north as we turn in for the night.

\section{May i4. Bulawayo.}

We arrived here about 9 o'clock this morning, having taken just twenty-four hours to do the 490 miles between this place and Mafekingcertainly not a reckless speed. We have spent the day looking about the town, which, on a still day in winter, is quite an agreeable spot, but in hot windy weather it must be anything but that, as it is no exaggeration to say, that in many of the streets, there was fine reddish dust fully two or three inches in depth. The Rhodes Statue in the centre of the town is most effective. We lunched at the Grand Hotel, which appears to be much too grand for the requirements of present day Bulawayo, 
i 8 Diary of a Tour in South Africa.

which town, however, is certain to become of considerable importance in the future. Having made arrangements for our trip to the Motoppo Hills to-morrow, we have come back to the car for a quiet evening.

Walking about the streets of this well planned town, one can hardly realise, that in I893, Bulawayo (meaning "the place of the killing"), was merely the head kraal of the bloodthirsty Lobengula. The rateable value of the town now is assessed at $£^{2,000,000}$. It was originally our intention, before going on to the Falls, to have gone up the Salisbury line as far as Gwelo, thence by branch line twenty-two miles to Selukwe, from which place we had arranged to drive in carts to the Zimbabwe Ruins, eighty-eight miles distant, but, on reconsideration of the matter, we decided to abandon this part of the trip, as it meant two days of continuous rough driving each way, with no very decent sleeping accom- 
modation en route. In deciding to cancel the above arrangement, we were influenced by two considerations; first, that we had seen all the ruins of Egypt, and we suspected that, after these, the Zimbabwe might be an anticlimax; and secondly, and not least, we were all getting pretty tired of knocking about on South African so-called roads. The only complication arose from the fact that we had arranged to have the week's mail sent on to Gwelo, but we managed to get telegraphic authority from the Postmaster-General for Southern Rhodesia at Salisbury, for the officials there to open the mail bag as it passed through, which was fortunate. Had we not managed this, we should not have got our mail for another week, as trains in these parts are very infrequent.

The entire constellation of the Plough is visible to-night low down on the horizon. We have now travelled 4,5 I6 miles in our car since leaving Cape Town. 
I 20 Diary of a Tour in South Africa.

\section{May 15.}

This has been a red-letter day in this trip, full as it has been of novel and interesting experiences. To-day's excursion from Bulawayo to the Motoppos has been of such outstanding interest that it can never fade from one's mind, as the years roll on. We left Bulawayo about 9.30 this morning in a large and powerful motor car. Although the distance is only about twenty miles, it was eleven o'clock when we reached the very comfortable hotel, overlooking the Dam. The road for the first part, being as usual, of a kind that we could hardly class at all in our country as a road. After some eight or nine miles of this, one enters a private road, made by the Rhodes Trustees. This is extremely well made, and kept in good condition, no heavy traffic of bullock waggons and the like being allowed upon it. 
CECIL RHODES'S LAST RESTING-PLACE. 


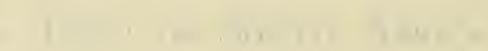

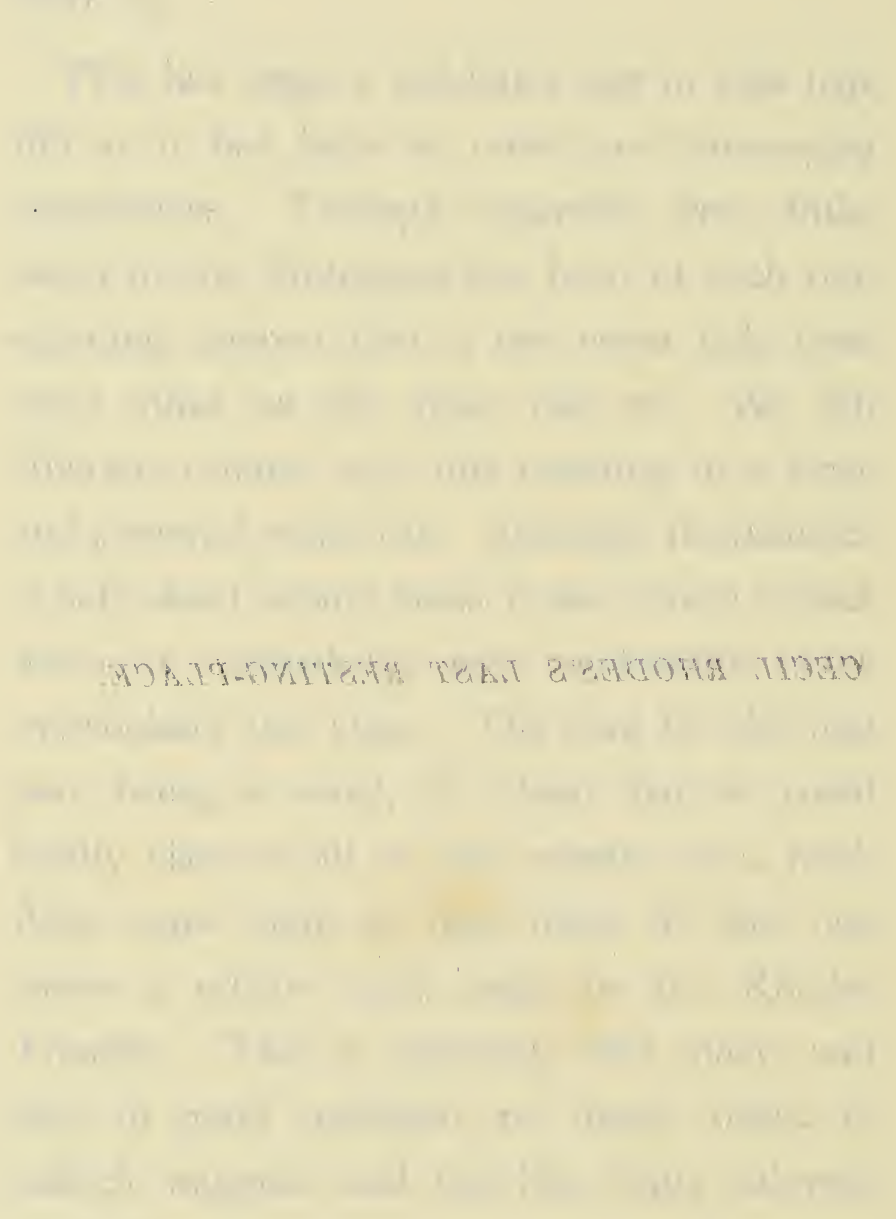




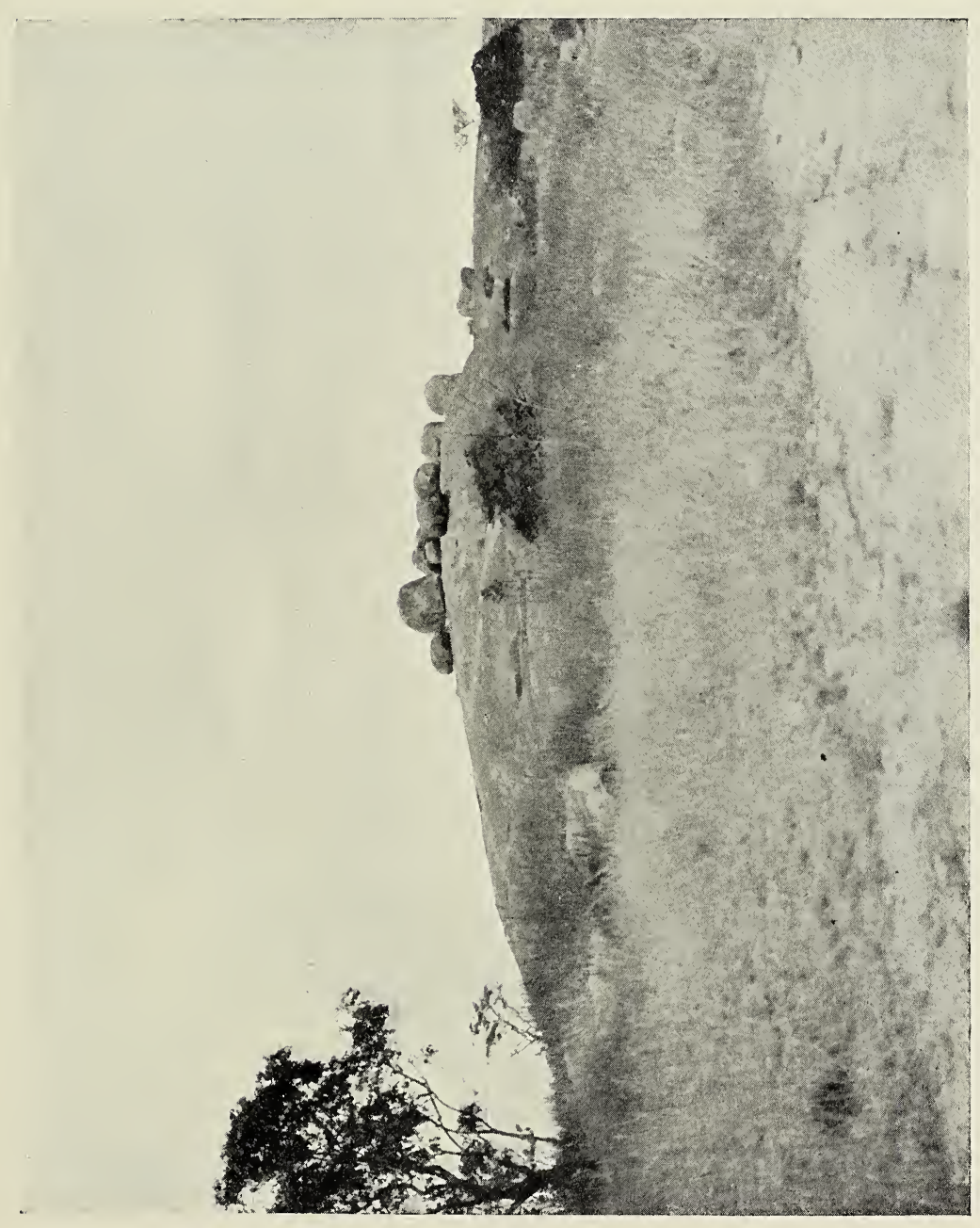



Diary of a Tour in South Africa. 121

On leaving Bulawayo one wonders if the Motoppos are a myth, as in scanning the surrounding country, one sees absolutely no sign of hills, but quite suddenly, soon after entering the private road, one gets a glimpse in the distance of what appears to be the battlements of an immense castle, and that was our first view of the famed Motoppos, the impregnable stronghold of the Matabili in the rebellion of 1896 . The Motoppo Hills extend for a distance of about 100 miles in length, by about thirty-five broad. Having reached the Motoppo Dam Hotel, we made a halt for a few minutes to order our lunch, and then resumed our journey. Soon after leaving the hotel, one enters the ground which Mr. Rhodes directed in his will, should be made into a public park for the use of the people of Bulawayo. It is planted with almost every kind of tree in existence, and also contains large numbers of rare animals. The drive through 
122 Diary of a Tour in South Africa.

the park extends to about three or four miles. During this section of our drive we startled a large troop of baboons. It was quite impossible to count them, as they went off in great haste to the hills, but there were certainly fifty or sixty, possibly many more, some of them very big fellows. The road came to an abrupt termination, at the point where it is necessary to begin the climb to view the last restingplace of the Colossus of South Africa. A climb of about half an hour brought us to the top of the hill named by Cecil Rhodes, "The View of the World," and there in the midst of huge boulders, is a large marble slab, with the following inscription upon it-"Here lie the remains of CECIL JoHn Rhodes."

As we stood gazing at the grave of this great empire builder, one's mind involuntarily travelled back to that day in 1896 when he came out into these lonely hills, with only a couple of companions, all three unarmed, in 
THE GRAVE AND ITS GUARDIAN. 



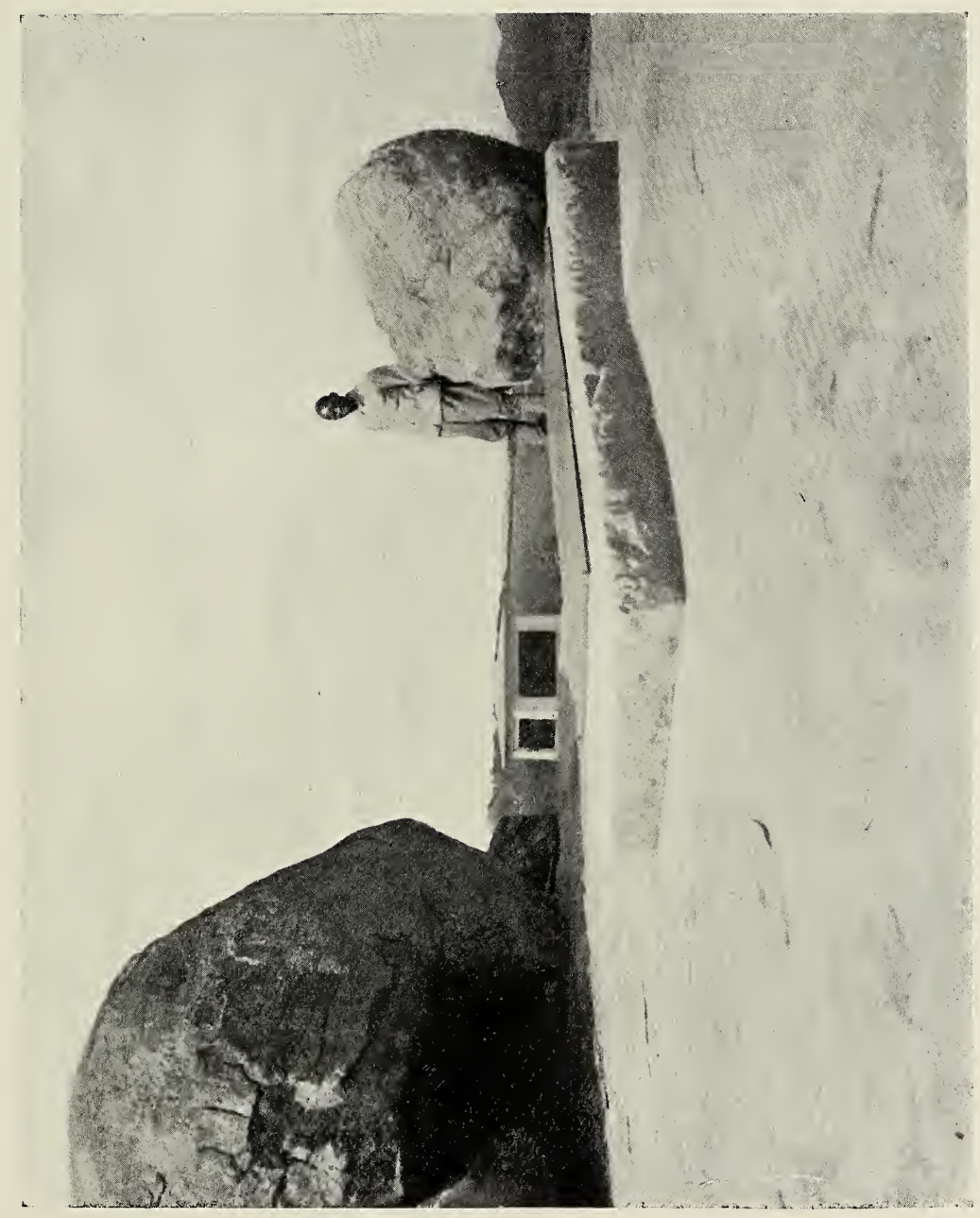



Diary of a Tour in South Africa. I 23

order to treat with the savage Matabili, who at that stage of the rebellion had retired to an impregnable position in these mountain solitudes; and by the sheer force of his great personality, overawed the bloodthirsty warriors, and brought about peace, after what had already been a bloody war, and which at that time promised to be of long duration. One's thoughts also travelled back to distant Britain, where, after this great man's death, puny people wrote letters to the papers, and held meetings protesting against a service taking place in Westminster Abbey to his memory; presumably on the grounds that the views of Cecil John Rhodes on some points, did not coincide with their own, but more probably with the amiable intention of advertising their insignificant selves. One can only hope that later on when the contents of his will became known, the said detractors would be properly ashamed of themselves, which is extremely 


\section{i 24 Diary of a Tour in South Africa.}

doubtful, and hardly to be expected of that type of humanity.

The view from the grave is quite indescribable, and must be seen to be appreciated, as no camera can give any version of its immensity. It is a perfect ocean of enormous granite formations, consisting of huge boulders in inaccessible positions, and weird and fantastic shapes stretching in every direction as far as the eye can reach ; utterly devoid of life, except for an occasional klipspringer (the chamois of South Africa) leaping from crag to crag. Near the grave, is a large and beautiful memorial, erected by Mr. Rhodes to the memory of Major Allan Wilson and his men, who were killed to the last man at the Shangani River, fighting against the Matabili. The monument bears the simple inscription"There was no survivor." Writing of inscriptions reminds me, that as soon as we left the motor car, and began our climb to the grave, 
Diary of a Tour in South Africa. I 25

we were closely followed by a powerful black "gentleman," who very decidedly kept his eye upon us. He both ascended and descended with us, and it was a matter of great surprise to us all that the "backsheesh" question was not introduced, and we were naturally all somewhat mystified. Later on we learned from the driver of our car, that he, the gentleman in black, had recently been appointed by the Rhodes Trustees to follow everyone going up to the grave; as not long before an American had scratched his beautiful name on the marble slab covering the grave, and although the Trustees had offered $£ \mathrm{I}$,ooo for the discovery of the offender, they had been unsuccessful in finding him. To judge by the build of the nigger guardian, he was quite capable of preventing any more diabolical work of that nature. Our next move was back to the hotel, where we found lunch ready for us, and by this time we were more than ready for it. 
From the hotel a good view of the Motoppos Dam, constructed by Mr. Rhodes at a cost of $£ 30,000$, is obtained. By means of this dam, sufficient water is stored to produce two crops yearly in the valley below, from a large tract of country that had been nothing but desert and bush, before the construction of the dam. Mr. Rhodes had a house in the neighbourhood, and it was, I believe, his favourite residence. In the late afternoon we returned to our trainhome at Bulawayo, greatly charmed with the day's experiences.

May i6. Sunday.

This has been a welcome rest after yesterday's strenuous day. My notes of it are as follows :- Late breakfast in car ; later lunch at Grand Hotel; then sleep and snores from entire party in the smoking-room; and back to car for dinner. Very hot to-day, temperature about $80^{\circ}$ in the evening in dining-room. 
THE ALLAN WILSON MONUMENT'-MOTOPPO HILLS. 


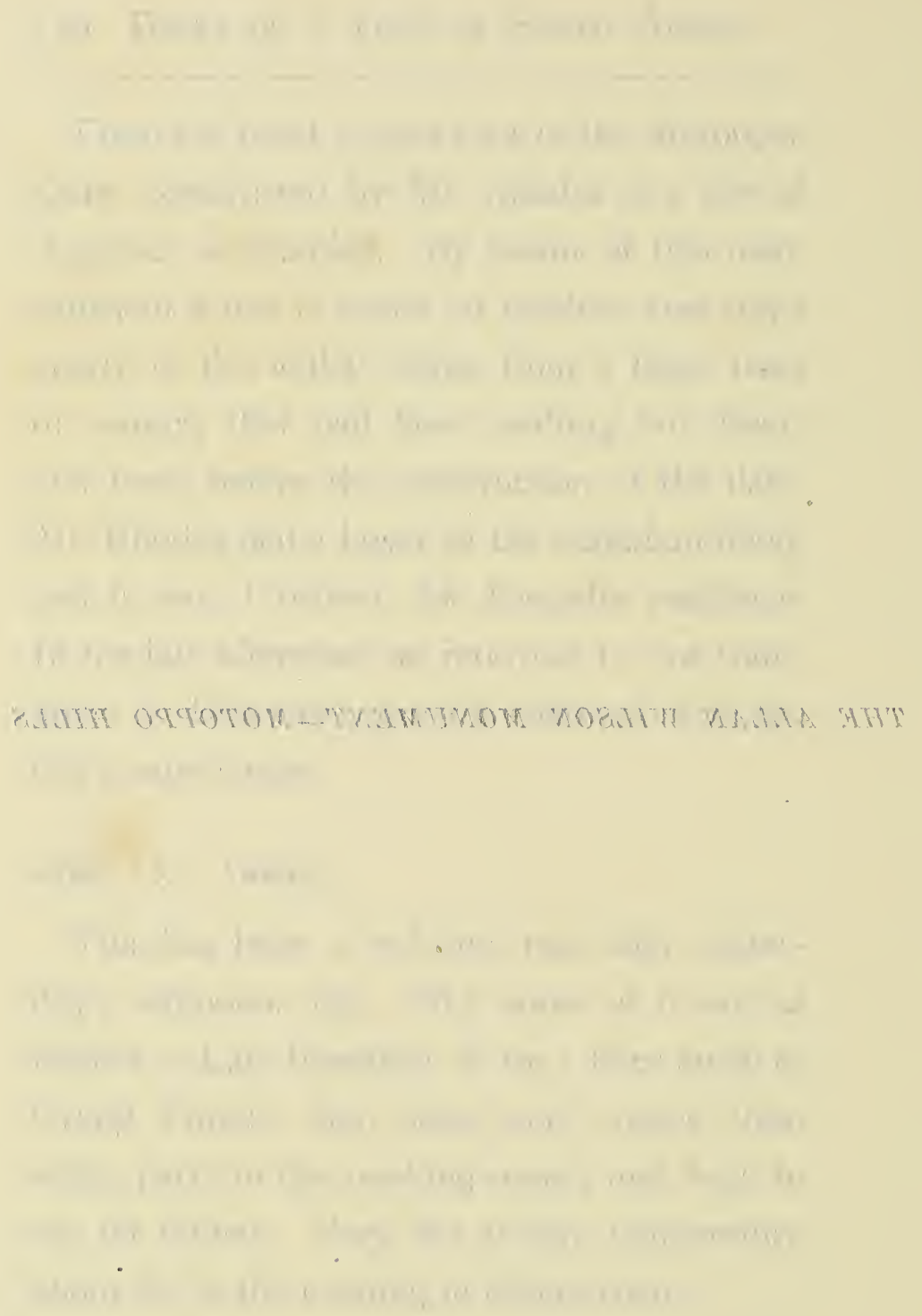




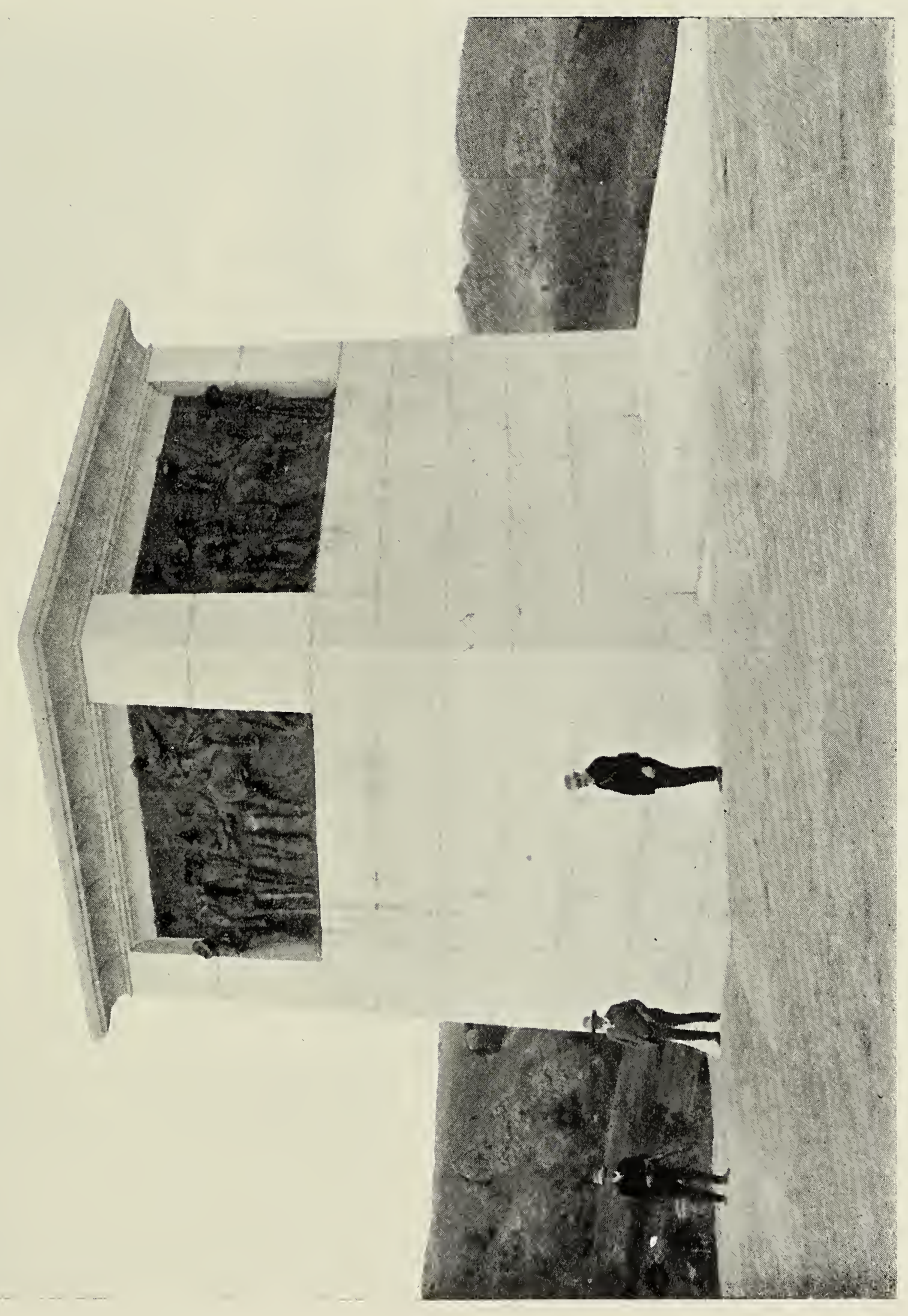


Diary of a Tour in South Africa. i 27

May I7.

We have had a quiet morning in the car, and it has been much appreciated by all of us, as we find this tropical heat rather trying. After lunch we drove out to Government House, which is connected with Bulawayo by an avenue nearly two miles in length, well planted with trees. Government House is built on the site of Lobengula's old kraal, and was originally erected as a residence for the late Mr. Rhodes. In the grounds we saw the famous tree under which Lobengula dispensed justice, or more probably brutalities on a large scale. Although it was the late afternoon of a cloudy day, I was most fortunate in getting a good photograph of that famed tree, which must have been a witness of many terrible tragedies in bygone times. We have now seen all that is interesting about Bulawayo, and are going on to the Falls to-morrow morning. 
i28 Diary of a Tour in South Africa.

Fortunately we were able to get that Gwelo mail-bag, which I have already spoken of, opened here to-night, and were delighted to get our letters about Io P.M., particularly as they are the first we have received in reply to those we posted when we landed at Cape Town on March 30. Forty-nine days seemed a long time to wait for a reply to one's letters ; but as we all have had good news from home, we soon forgot the forty-nine days' wait.

\section{May 18.}

At ro o'clock this morning we started for what is really the raison d'être of this long journey, viz., the far-famed Victoria Falls, the promised view of which has been ever present in our minds, as we explored battlefields, jolted our more or less old bones in Cape carts over trackless veldt, or did our almost daily dole of railway grind, often rather satiated with the odours evolved by M. le Chef and his assistant 
Diary of a Tour in South Africa. I 29

Kaffir imp. But, after all, who can expect fish of all things, to be just perfect, when it has come by rail a couple of thousand miles from the sea, and the supply of ice has failed; and who would blame our cheerful Medical Professor for saying to Clark, our steward, one morning at breakfast, "Look here, Clark, I'd much prefer the fish on one plate, and the stink on another, if you don't object." To-day most of our journey has been through teak and mahogany forests, with an undergrowth of very tall grass. We have seen many charred remains of huge trunks still standing, doubtless reminiscences of forest fires of bygone ages. Our rate of travel is slow, as we are taking twenty-one hours to do the 280 miles, which separate Bulawayo from Victoria Falls, and stations are by no means numerous.

It was dark before we reached the Wankie Coal Fields district, but on our return journey I think we shall manage to pass through it 
izo Diary of a Tour in South Africa.

during the day. We turned in to-night full of of expectancy for the morning.

May igth to 24th. Victoria Falls.

3,000 feet above sea level, and 280 miles from Bulawayo. Our record is now 4,796 miles since leaving Cape Town.

I think I wakened this morning in the expectancy of at least hearing the distant roar of these mighty Falls, as I knew that the station at which we had come to anchor was barely a mile distant from them, but all was quiet and dusty as usual, which at the time I thought distinctly strange, particularly as we knew, on excellent authority, that with the river in flood, as it was at this date, the spray was rising on a still day to a height of 3,000 feet, and could sometimes be seen at a distance of forty miles. Before I attempt to give my friends a description of these immense Falls, I wish to say that my feeling after a 
THE ANNEX-VICTORIA FALIS HOTEL. 



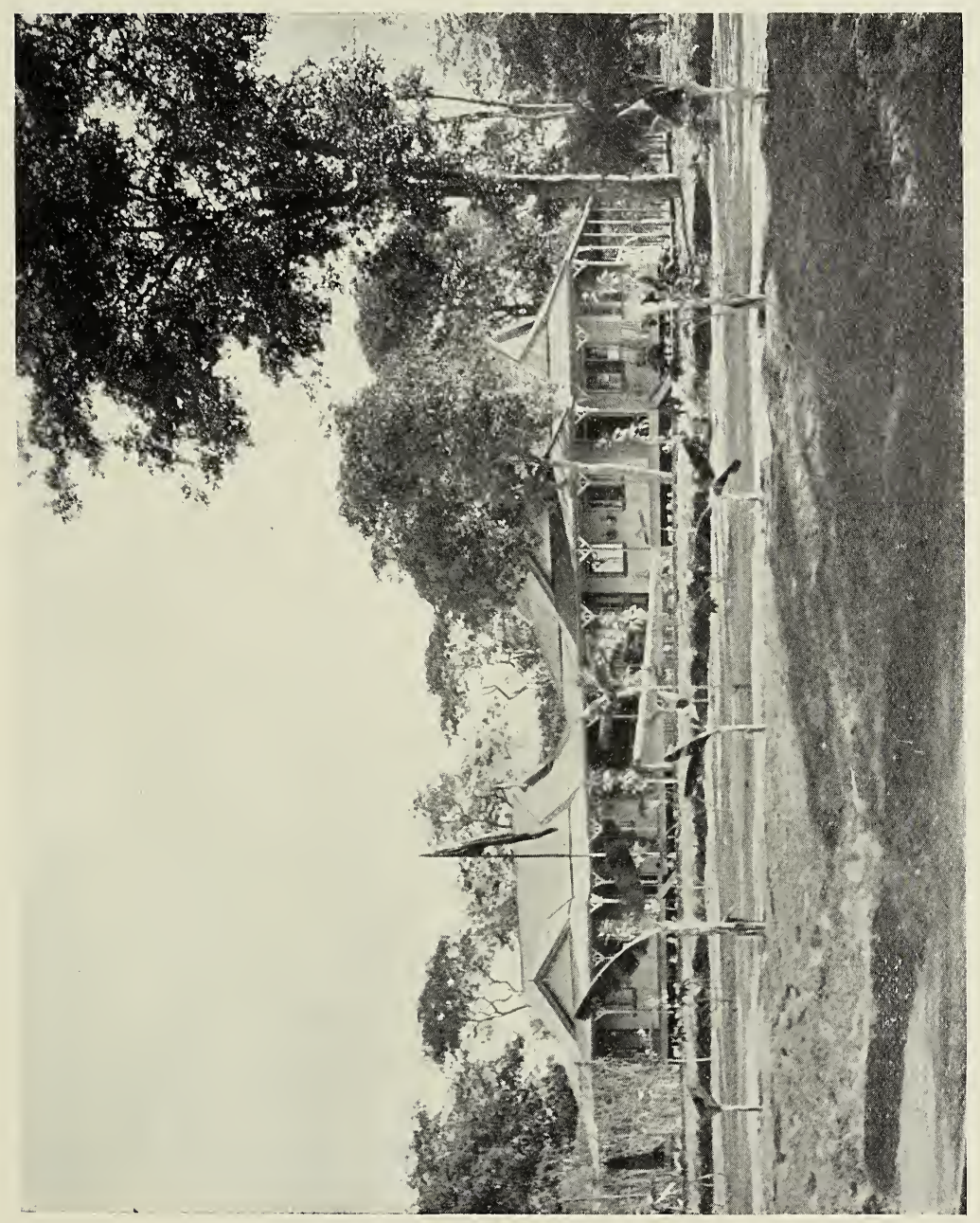



THE GORGE OF THE ZAMBESI AND BRIDGE. 


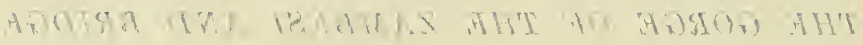




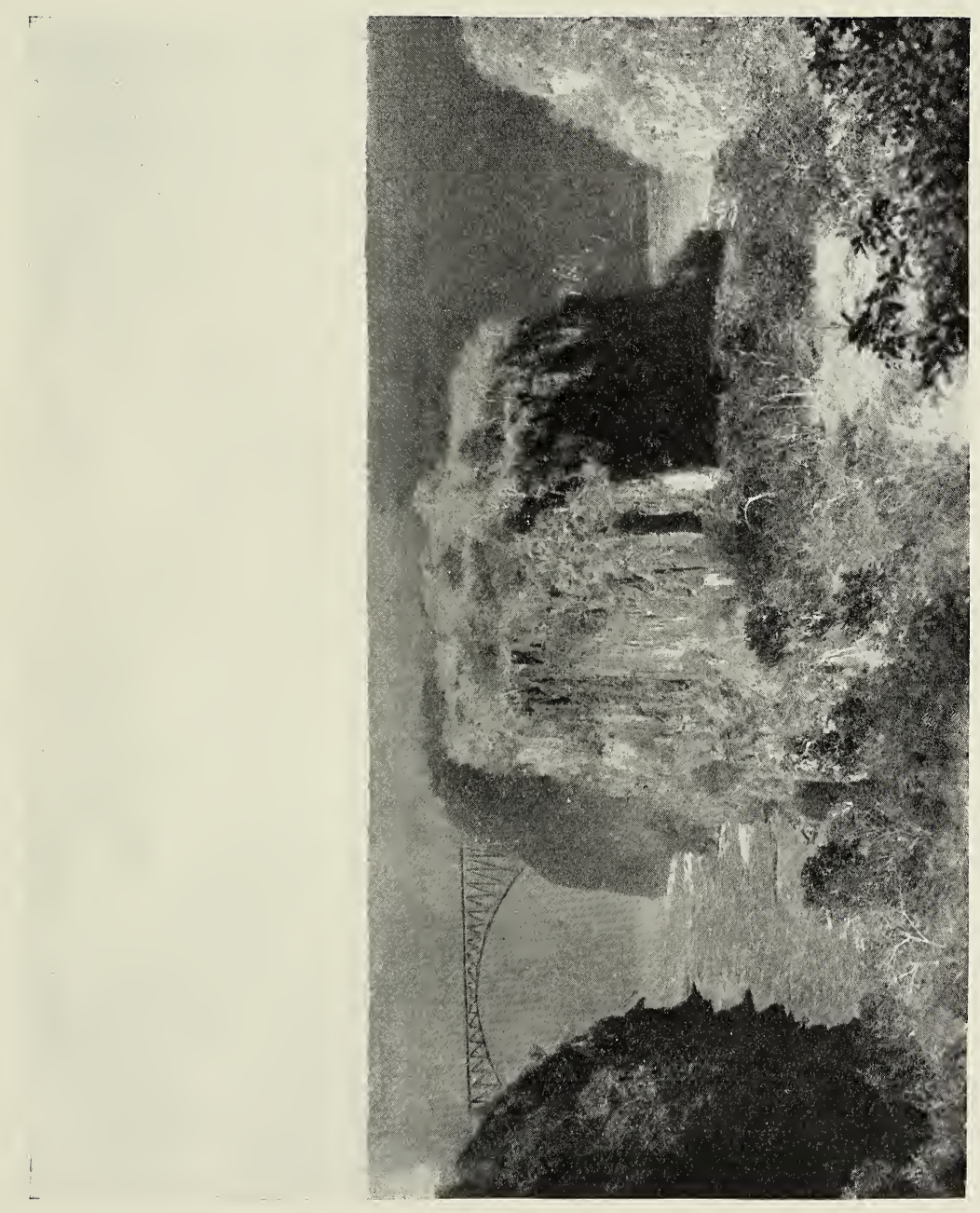



THE WHIRLPOOL BELOW BRIDGE, FROM PALM KLOOF. 


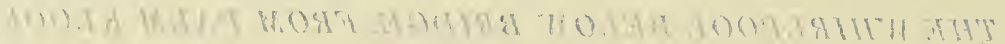




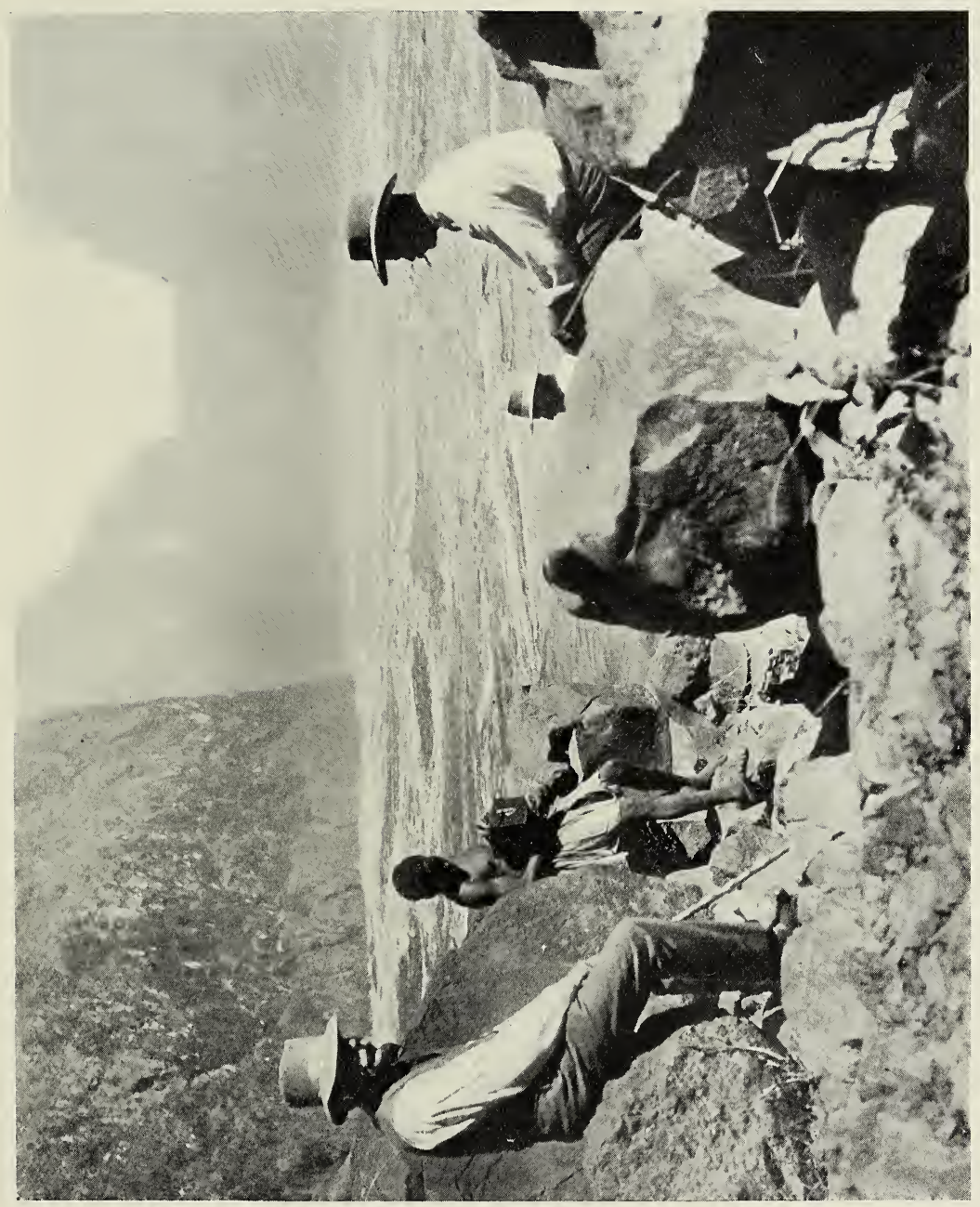



RAPIDS ABOVE EASTERN CATARACT'VICTORIA FALLS. 


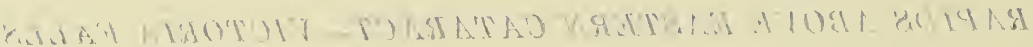




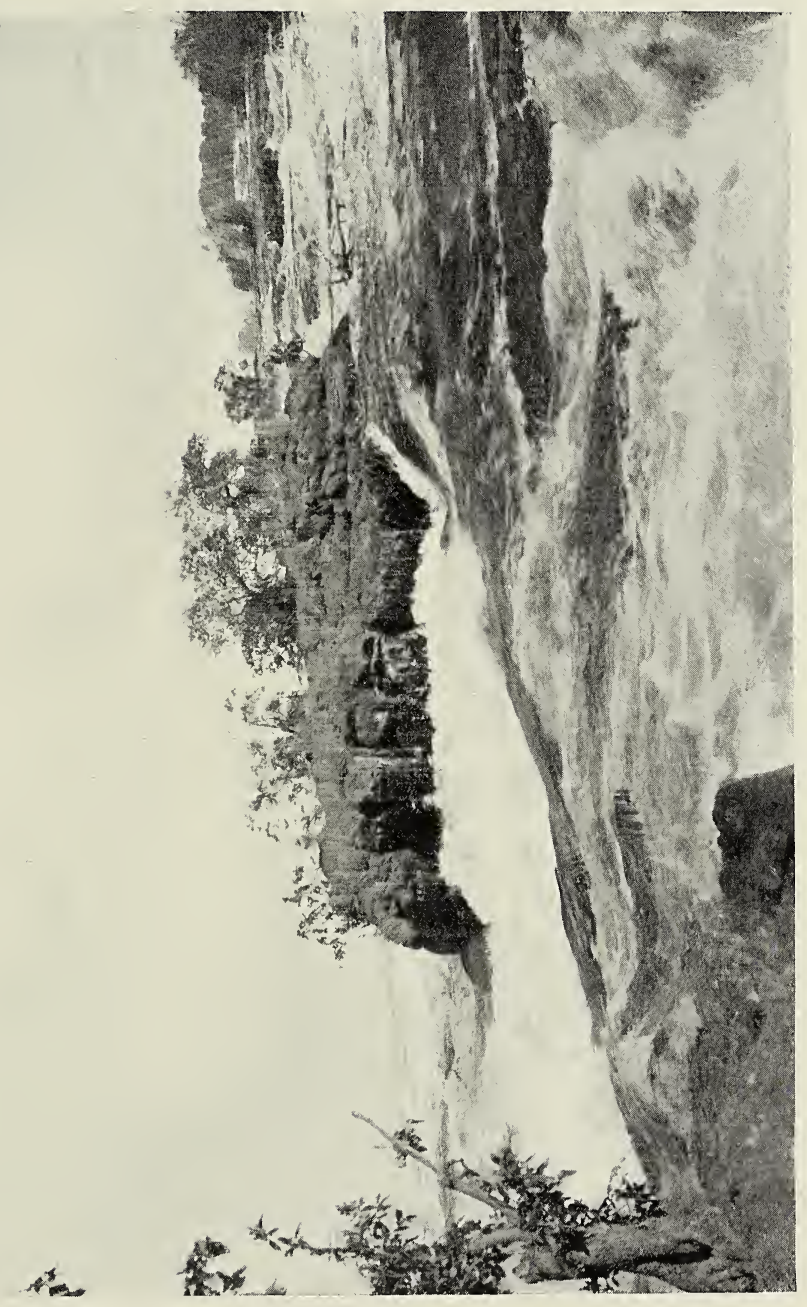



Diary of a Tour in South Africa. i 3 I

sight of them, was, that they are to the eye what a great symphony is to the ear, and that any attempt through words to convey to the minds of others the immensity of their grandeur, would be about as inspiring as the newspaper musical critic's usually feeble attempt to portray the symphony. I have read a number of "impressions" of various distinguished people about the Falls, which seemed good enough before I had seen them, and now, having seen them myself, the aforesaid impressions seem distinctly weak. This feeling that I have about the matter need not, however, prevent me giving a number of details, which, with accompanying photos, may be of interest to many friends who have not had my good luck to wander so far.

On turning out of the car this morning, the first person we met was our old acquaintance of the s. s. Briton, Sir Charles Metcalfe, the designer of the bridge over the Zambesi, 
i 32 Diary of a Tour in South Africa.

also engineer to the line which will eventually connect the Cape with Cairo. Since we parted on the arrival of the Briton at Cape Town, he had been up country in connection with the extension of the railway some i 50 miles beyond Broken Hill, the then railhead, a section that has been completed since our visit. Sir Charles told us that he had tramped the entire distance of 300 miles through the jungle, and had not seen a trace of game, (although at times it could be heard,) on account of the dense high grass, which was about a month later than usual, owing to the very late rains of that season. He advised us to give up all idea of shooting in North Western Rhodesia, unless we were prepared to wait up at the Falls for another month or six weeks, until the grass would be down. This opinion coincided with that obtained from the resident engineer of this section of the line, whose acquaintance we made later 
THE EASTERN CATARACT. 


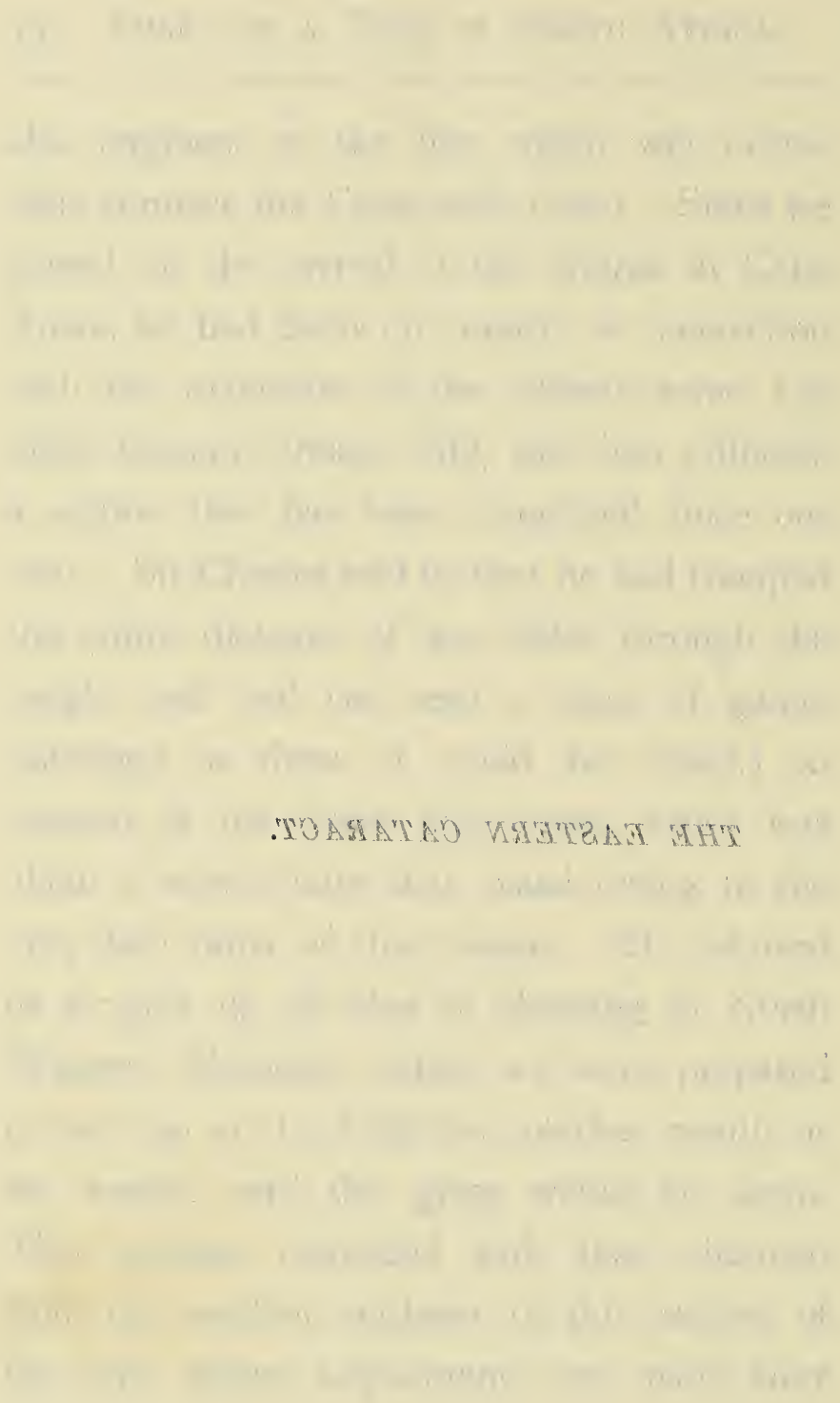




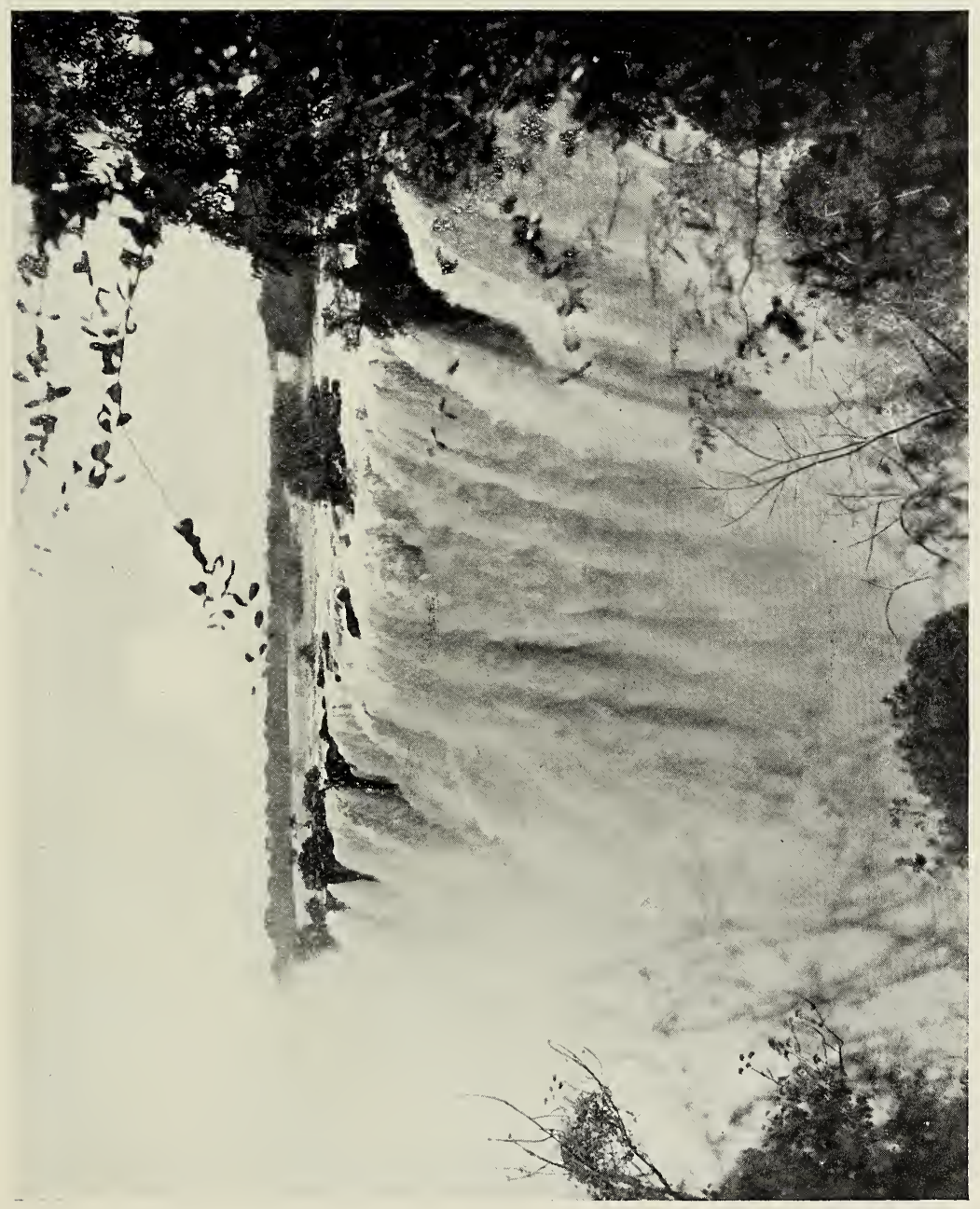



MAIN FALLS AND LIVINGSTONE ISLAND. 


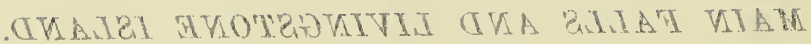




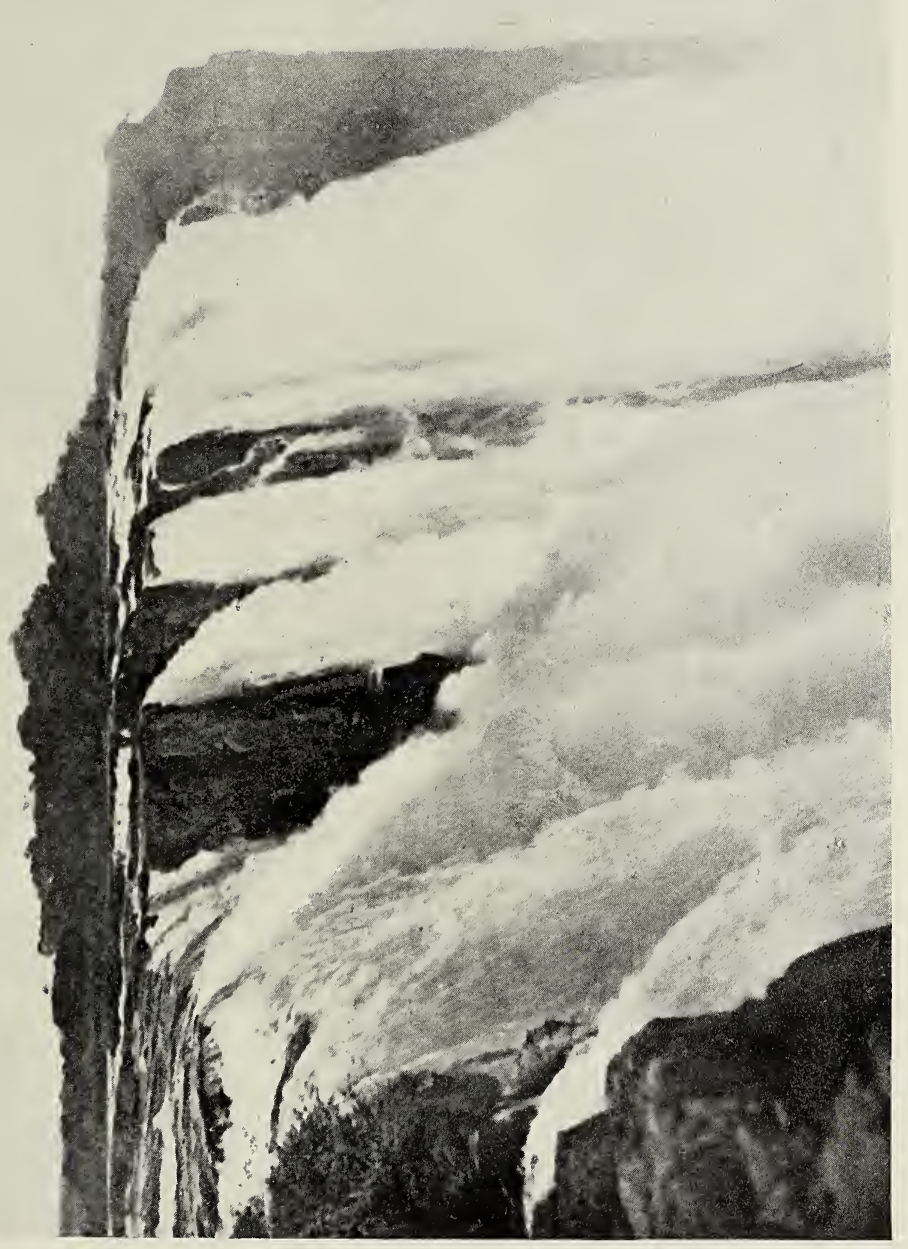



Diary of a Tour in South Africa. 133

on, and who thought our only chance lay in loafing about on a railway trolley, between the Falls and Broken Hill, keeping a sharp look out for trains, as being more dangerous than lions. Thus the expectation of the sporting members of our party received a severe blow, and, I may say finally vanished.

Our hosts now set about getting quarters at the Hotel, and decided to go into the so-called Annex; really four semi-detached bungalows, (much frequented by honeymoon couples we were told); two of which were taken for our use, and were found to be most comfortable. When our goods and chattels had been brought over from the car, we deserted our jerky home of the past nearly seven weeks, for a real house. Just think of it, ye who find a journey from Glasgow to London rather long and tiring! Everything was really very nice at the Hotel, except the large quantities of Zambesi hornets, which seemed to take a 


\section{i 34 Diary of a Tour in South Africa.}

special fancy to our bedrooms. They were horrible looking brutes, and the Professor's suggestion that they looked like winged Bengal tigers, did them no more than justice. Once in our beds at night, well protected with mosquito netting, we could smile at them, but the Professor and I (we shared a room), had about twenty of them helping us to dress one morning, and they needed a lot of getting used to. Afterwards we discovered, that like our own charming British wasps, they don't bother one much if let alone, but if you hit at a Zambesi hornet, you must kill him, or he hits back at once, taking no time to deliberate about the shortest distance between two points. I do not speak from personal experience, but I saw a demonstration. Having too many of these winged terrors in our bedrooms, we asked the Hotel Manager to have them ejected, and soon a detachment of three or four niggers arrived on the scene, armed with 
RAINBOW FALLS AND DANGER POINT. 



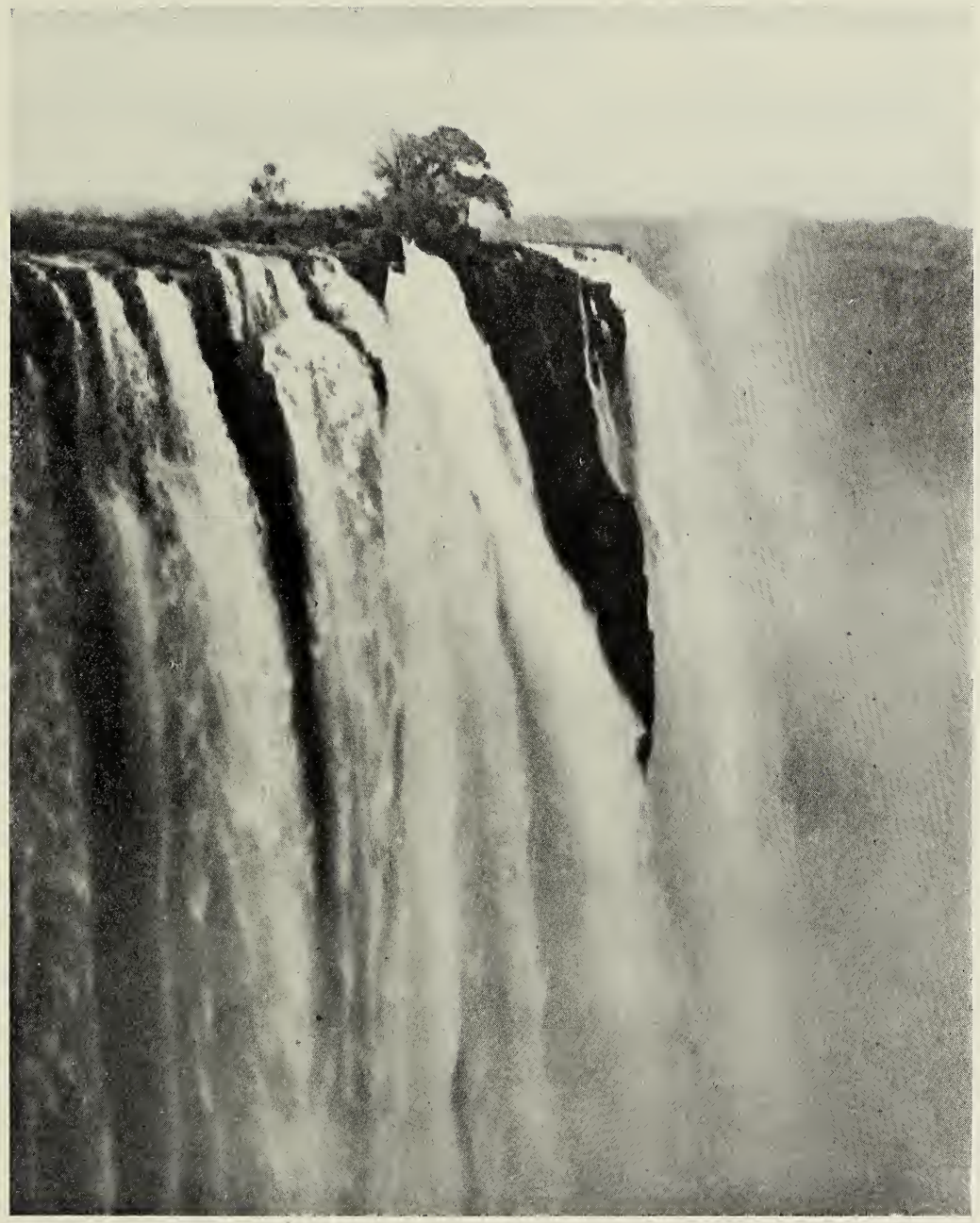



RAPIDS ABOVE LEAPING WATER-VICTORIA FALLS. 


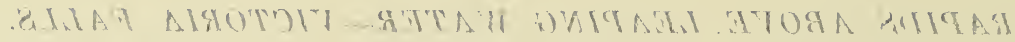




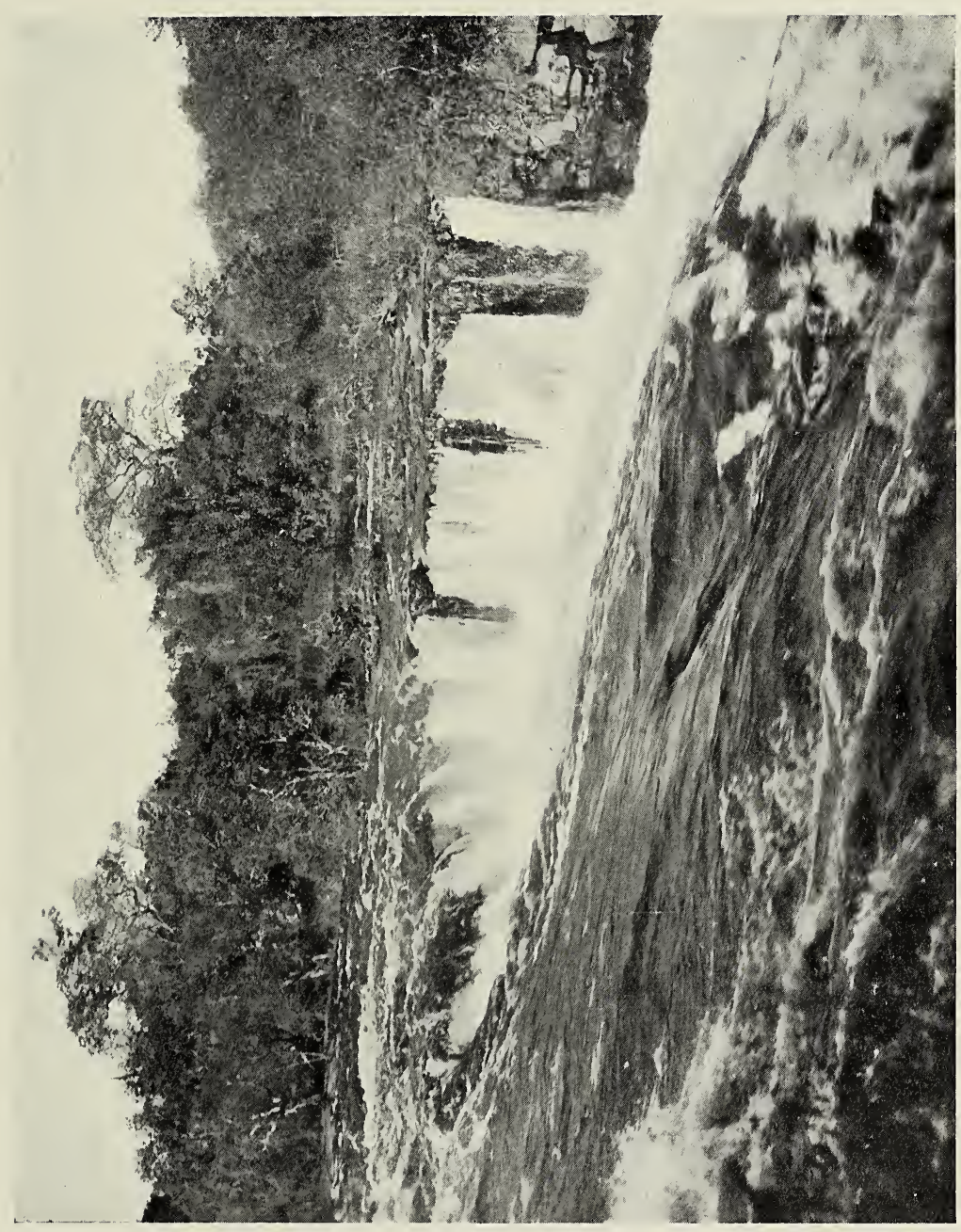



BRIDGE OVER THE ZAMBESI-HEIGHT, 4RO FEET. 


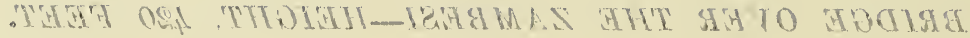




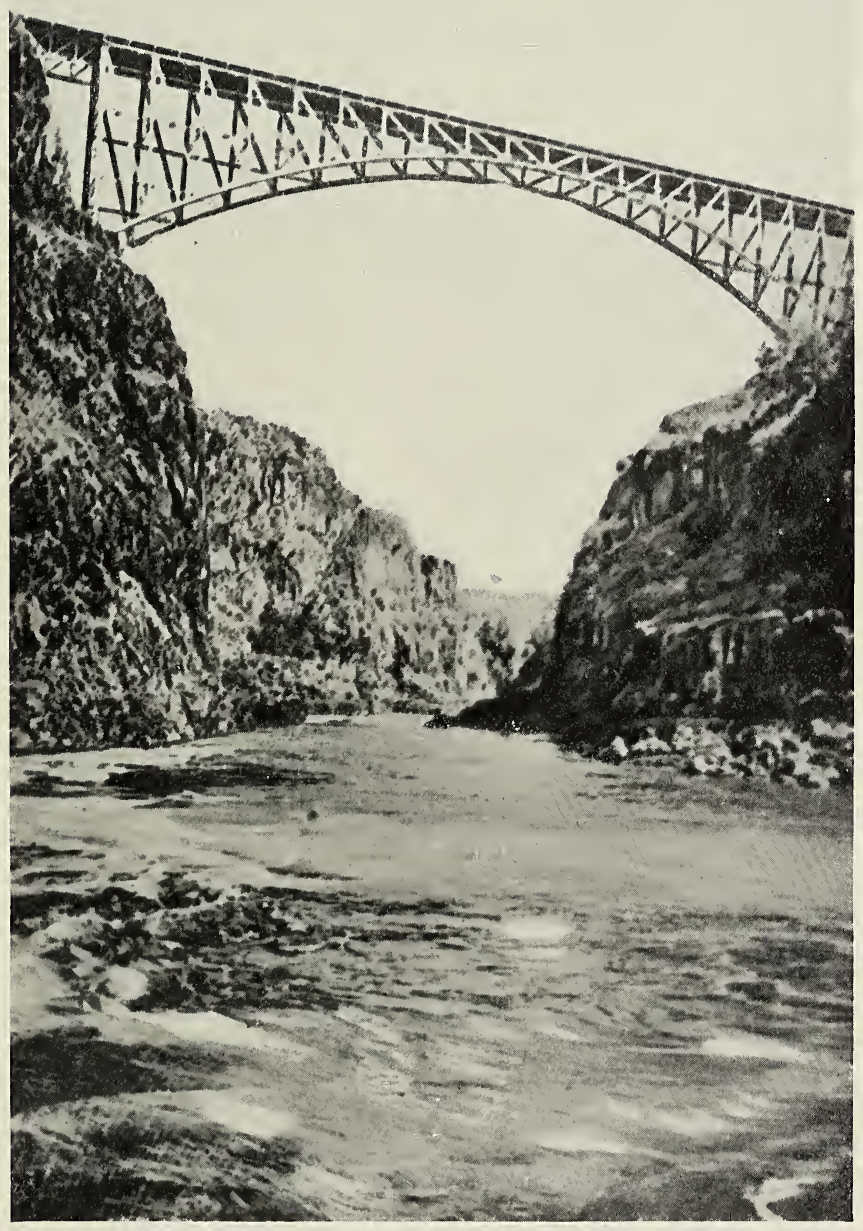



A TRIP OVER BRIDGE WITH RESIDENT ENGINEER. 


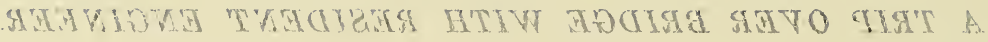




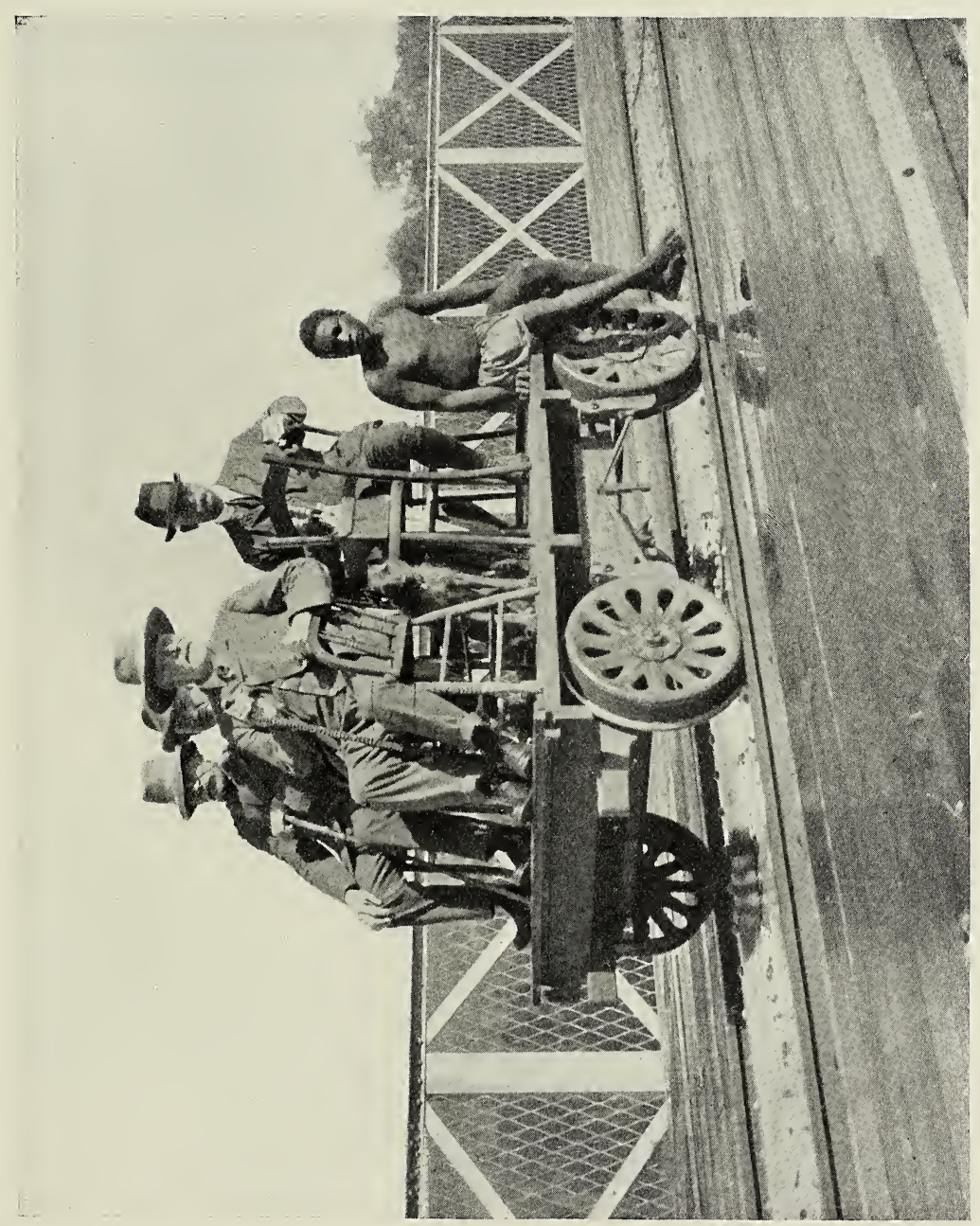



Diary of a Tour in South Africa. 135

butterfly nets, etc. One big nigger aimed a blow and missed, but the hornet didn't miss the nigger, who bolted for the door, but not before Mr. Hornet had fixed him on his bare back! All I can say is, that if the pain of that sting was in any proportion to the horrible scream given vent to by that nigger, then the pain was a very large one. However, this reminds me that we are here to see the Falls, not to catch hornets.

As most of the morning had been taken up with our "flitting," we only had time just before lunch to walk down to the railway bridge, and make ourselves a trifle giddy by looking over at the whirlpool, 420 feet below; then in the afternoon we lost no time in getting back to see as much as we could before dark. Although we had read a lot about the Falls, and seen many pictures, not one of us had any idea of their immensity, until we stood facing the 
136 Diary of a Tour in South Africa.

dull roar of their thundering waters. The peculiarity about these Falls is, that the general level of the country is the same, both above and below the cataracts, the water disappearing into a great fissure ; and it must be on account of this fact, that one hears very little at the station, only a mile distant - although one seems to feel a distinct tremor in the earth beneath one's feet-which tremor, however, was much more perceptible when lying in bed at night. It was also distinctly queer to hear the window casements in our bungalow rattling on a windless night. During our first afternoon we managed to get a general idea of things, but during the six days we spent at the Falls, we were fully occupied in seeing their beauties under varying conditions of light. The Zambesi, at the top of the cataract, is a mile and a quarter wide, and in flood as we saw it, is a deep and rapid river; which suddenly makes a plunge of about 400 feet into a chasm 
Diary of a Tour in South Africa. i 37

200 feet wide; on the opposite side of which at the western end, is the Rain Forest, always enveloped in dense spray in flood time. Near the eastern end of the chasm, a gorge, about roo feet wide at low water, leads out of the chasm at right angles to it, into what is called the "boiling pot," and whirlpool ; directly over which is the railway bridge, 420 feet above the water, the highest bridge in the world. After passing under the bridge, the river makes a series of zigzags, running in less than a mile in four contrary directions, the channel, as far as we saw it, being roughly about 100 yards wide. When one remembers that a river of the width of 1,900 yards has been compressed into this narrow gorge, one can form an idea of the awful current. This deep ravine extends for a distance of forty miles. For the benefit of those who, like my three travelling companions, had seen the Niagara Falls, I give this comparison. The Victoria Falls are about twice 
as broad, and two and a half times as high as the former. I also give the following local comparison. The width of the Victoria Falls is two or three hundred yards more than the distance between the Paisley Cross, and Messrs. J. \& P. Coats's Ferguslie Works; and the height of them, some sixty to eighty feet more than the chimneys belonging to the above firm.

Owing to the narrowness of the chasm, and the ever present clouds of spray, it is of course impossible to see the Falls, except in sections. As our visit was at the time the Zambesi was in flood, it was most difficult to obtain photographs, but, after repeated visits, I was able to obtain good negatives of the Eastern Cataract and other points of interest, but found it quite hopeless to get decent negatives of the Main Fall, the Rainbow Fall, the Chasm, and the entrance to the Gorge, and those of the above that I produce have been made from negatives obtained in the dry season. The 
THE CHASM-VICTORIA FALLS. 


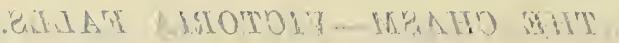

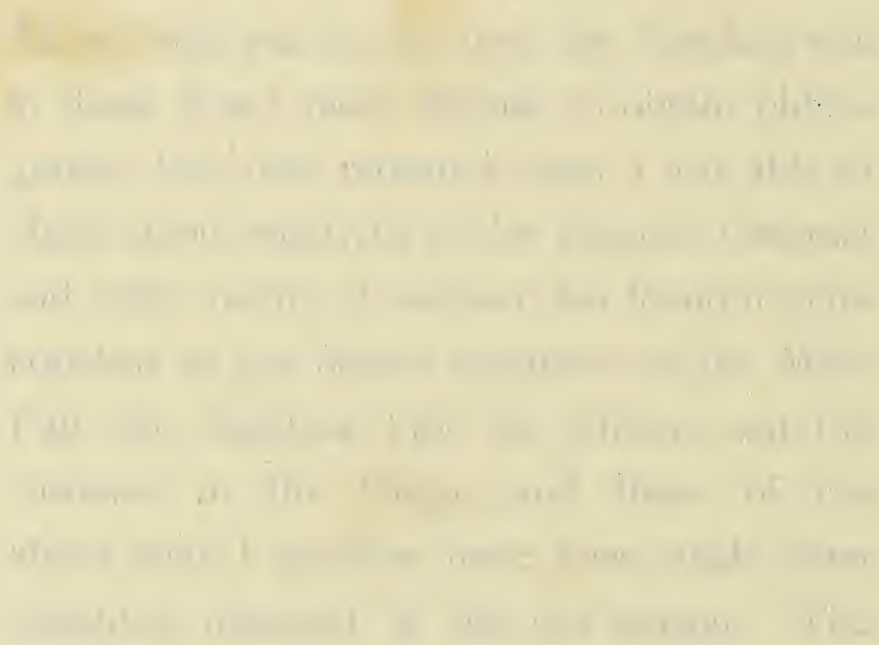




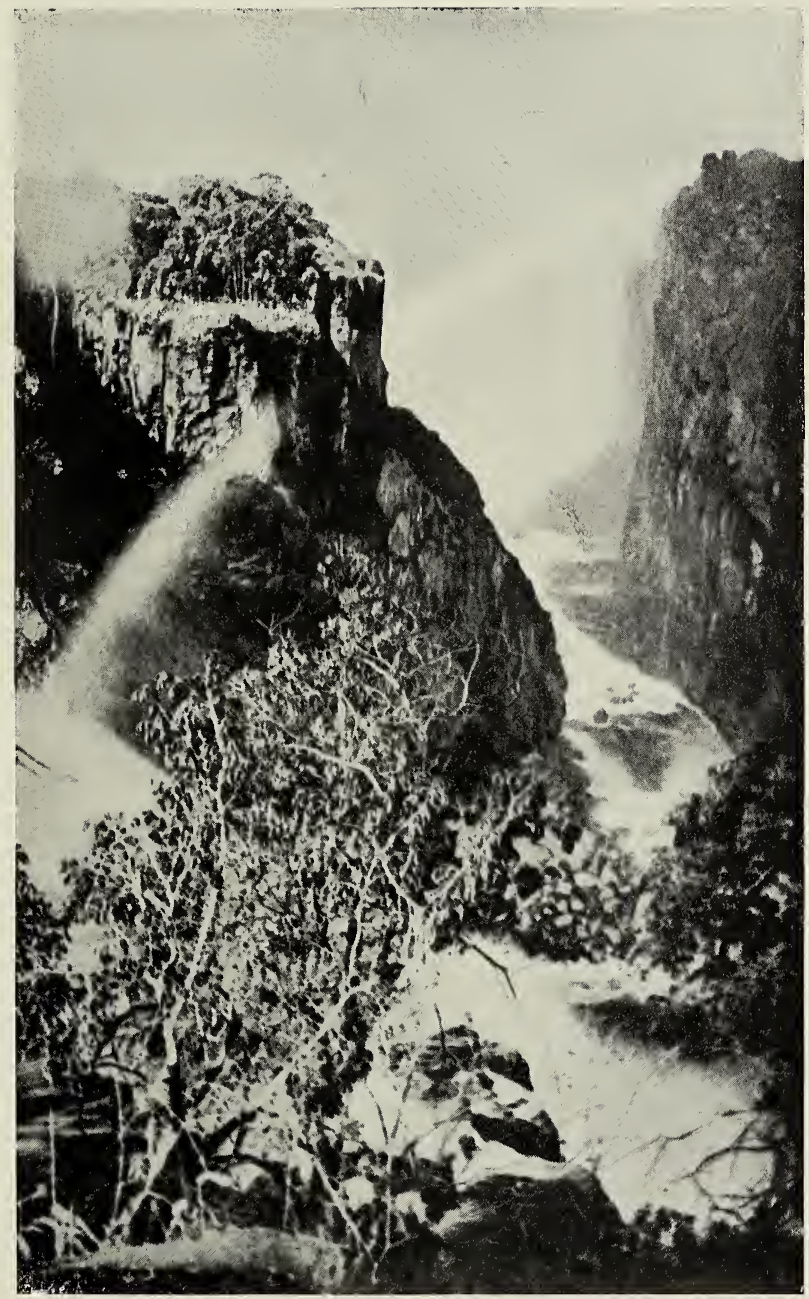


. 
one I reproduce of the Main Fall, gives also a good view of Livingstone Island, which extends to the extreme edge of the Fall. With the river in the condition shewn in the picture, it is quite safe to cross to the Island in a canoe. From this view of the Main Fall, one can get very little idea of the mighty torrent we beheld, when all the rocks on the edge of the Fall were submerged by many feet of water; nor can one get any idea of the great height of it, owing to the close proximity of the Rain Forest, from which the photograph is taken, it being at the same level as the top of the Fall, as can be seen in the photograph I reproduce of the Chasm, which shews the Falls on the left, and the Rain Forest opposite. The picture of the entrance from the Chasm to the Gorge, gives one an idea of the great height of the Falls, also of the very narrow outlet (about roo feet at low water), through which the enormous volume of the waters of 
the Zambesi in flood must pass. At such times, nothing can be seen at this point except momentary glimpses of the Fall, owing to the perpetual clouds of dense spray, so dense, that standing as we did, on Danger Point immediately above, one is drenched in a moment, as if one were standing in torrential rain.

On the second day of our stay, we made a most interesting excursion on the Upper Zambesi, as far as Kandahar Island. Soon after breakfast we made a start, walking on the western bank as far as Giese's Ferry, about half a mile above the Falls. Here we went aboard a very comfortable motor launch, and soon got under weigh, not without experiencing a few anxious moments, as after we had shoved off into the stream, the motor, after the habit of motors, refused to start until the fourth attempt, during which time we had begun to drift down stream towards that hideous drop of 
Diary of a Tour in South Africa. I4 1

400 feet, not so very far astern. I don't suppose there was really any danger, still it was, under the circumstances, quite a pleasant sound to hear that motor begin to take an interest in things! It took a long time to get up stream, as in many places the current was very powerful, and we were fully two hours doing the stretch of nine miles to Kandahar Island.

We landed amidst dense tropical growth. It was a bit swampy, and a likely abode of snakes. Possibly it was for this reason that we decided to have our lunch in the launch. The owner of the launch was a very pronounced American, his assistant engineer being a Dutchman. The huge nigger who was the "crew" was a magnificent animal of great height and breadth, with muscles moving under his sleek, black skin, and glittering in the hot sunlight. His easy, lazy, composed movements were most interesting, and his good-natured grin showed great, perfect, white Io 
I 42 Diary of a Tour in South Africa.

teeth, which looked as if they could crush oysters in their shells, or eat sardines without opening the tins, with digestion to match. The Laird envied his "Little Mary," not the outside of polished ebony, but the inside that could laugh at pickled onions and toasted cheese, and do a "rest cure" on roast pork and tinned lobster. $\mathrm{He}$ wore a superior manner and very little else, but no active contempt was in his gaze. Apparently we were merely weak-minded people far from home, like gentle lunatics escaped from friendly durance. His eyes looked on us with kindly toleration, and wandered over our figures and general kit without winking-not rudely, but more in pity for our ignorance, as much as to say, "Why don't you dress like me for this climate?"

$\mathrm{He}$ had nothing on to speak of during the heat of the day, so comparisons were impossible, but when his glance caught mine, 
VISIT TO KANDAHAR ISLAND. 



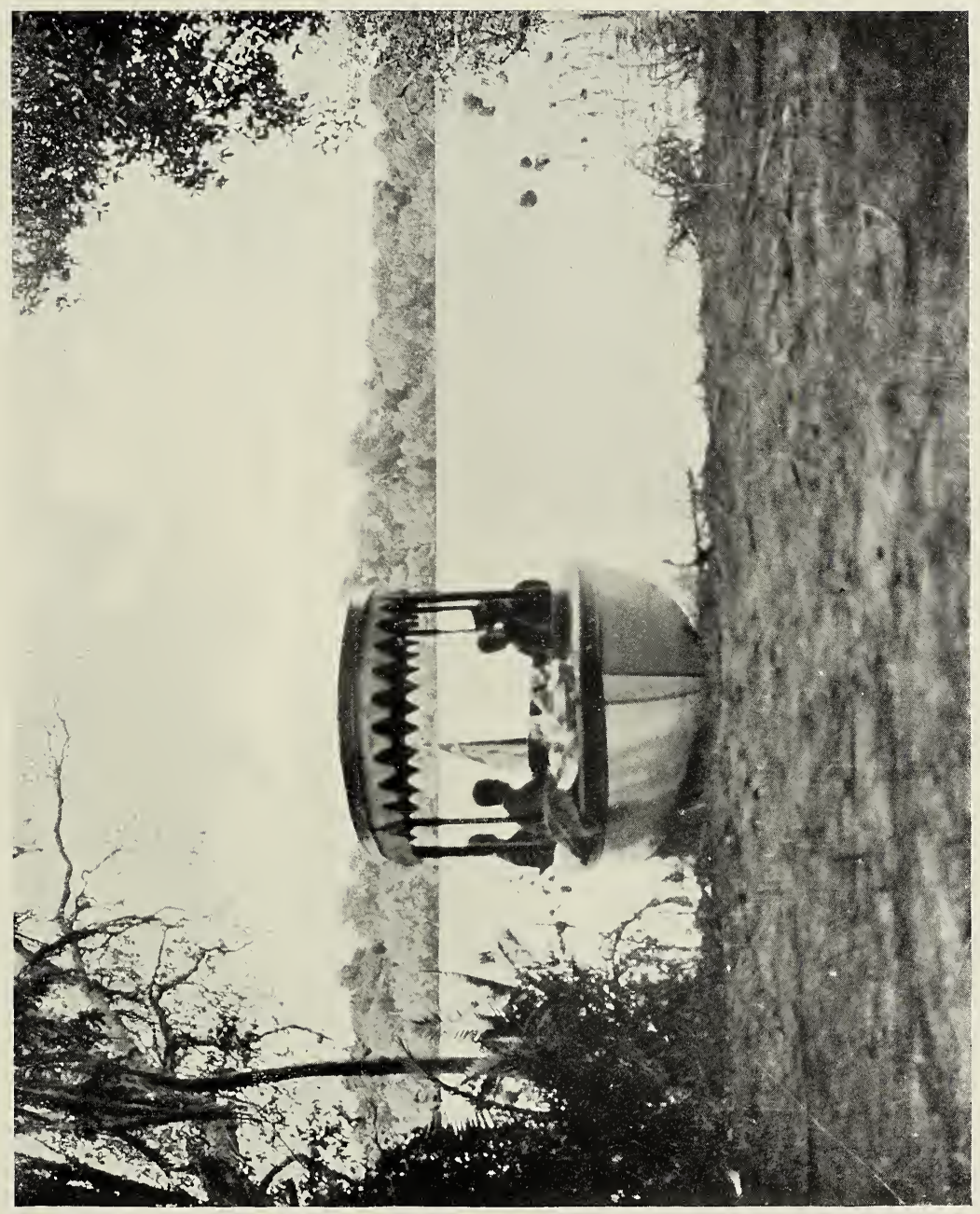



I felt embarrassed, and almost apologised for thus intruding into his country! And his table manners! Superb! I have never seen Royalty behave with more dignity, and the huge rascal's simplicity was most impressive. $\mathrm{He}$ had watched us eating with the slow, steady eyes of perfect indifference, but when he began his lunch, he gave me a look which clearly meant, "Now, poor creature, watch me. I will show you what table manners are ; imitate $m e$ in future." (He collected all the remains of the feast, and calmly, without haste, wolfed the lot.) Then he sat down on the grass under the palm trees, regardless of ants or other creeping terrors, and finished his own copious lunch provided by the boat's skipper.

The Laird suggested a knife and fork; he took them with polite good humour, as curios to be looked at and carefully laid aside, but proceeded in the correct way, with fingers and 


\section{i44 Diary of a Tour in South Africa.}

lips for the succulent portions, and teethmercy, what teeth!-TeETH for the bones. Then, when I began to feel depressed by his evident superiority to all my petty ideas of conventional etiquette, he finished me and his simple meal at the same moment by carefully licking his plate clean, quite clean! His great black face wandered round the white plate like an eclipse of the moon, but his eyes kept steady on mine, and I knew he was saying to me mentally, "Now, if you will do exactly like me among your weak white friends, they will know at once that you are one of the 'Nuts' of the Zambesi." (I have not tried it yet.) The Laird threw him a cigarette, like a chocolate to an elephant, but he failed to light it, so he chewed it, and, I presume, it ultimately joined the majority.

The river is not navigable for the next few miles above Kandahar Island owing to the presence of rapids, so, after lunch, we steamed 
TROPICAL FOLIAGE AT KANDAHAR ISLAND. 


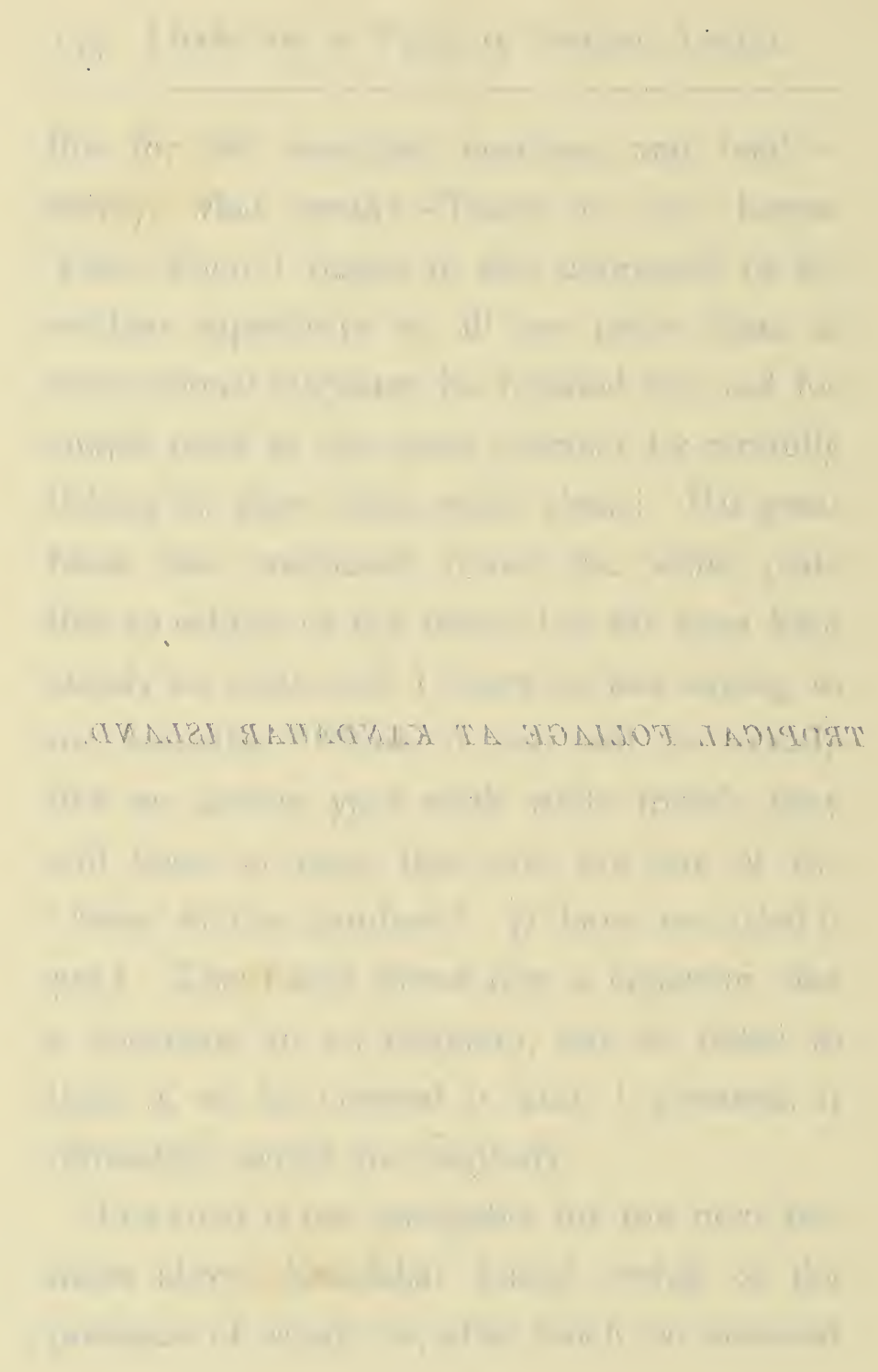




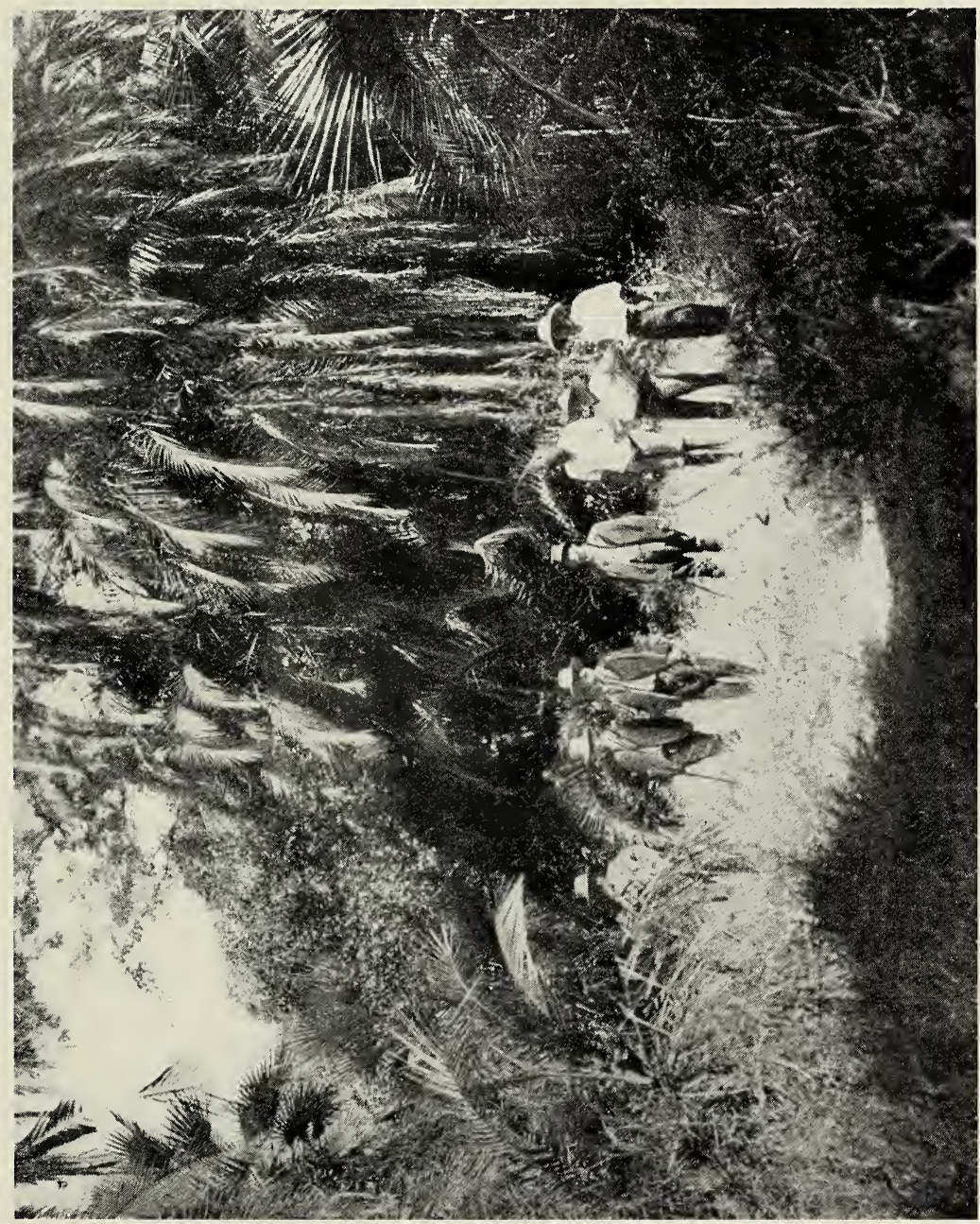





\section{Diary of a Tour in South Africa. I45}

a homeward course, also going three or four miles up the peaceful Mlamba River, a tributary of the Zambesi. We kept a sharp lookout all day for hippopotami, of which there are great herds in the river, but we were not fortunate enough to see a single one, the reason being-so our boatmen told us-that it was the breeding season, at which time the hippos keep to the creeks and sludgy places, and seldom come out into the stream. However, we were treated to stories of the prowess of the hippo, our boatmen pointing out to us the spot where one had capsized a canoe three weeks before, the occupants of which had been rescued with difficulty.

We also landed on the west bank to see a famous Baobab tree of enormous dimensions. We got several specimens of the fruit, about the size of a small marrow, very hard, and filled with an acid powder known locally as "Kerramatata " or "cream of tartar." It is 
i46 Diary of a Tour in South Africa.

valued by the Boers as a specific against fever. We reached Grise's Ferry just as the dusk was coming on, and, in walking home by the river bank, we saw numerous recent footprints of hippo. Our friend, the Engineer of this section of the railway, to whom we were indebted for much kindness and advice, told us that the relation of the hippo to barbed wire fencing in that neighbourhood, was a problem they had failed to solve. They had put up a number of fences of the strongest barbed wire they could get, the fence being made of several strands of it fixed on stout posts, and, as far as their observations went, they had come to the conclusion that the hippos walked through it without noticing its presence.

There are also great troops of baboons, and small, black-faced monkeys in the district, of which we saw a great many during our stay. The baboon appears to be shockingly human 
A FAMOUS BAOBAB TREE. 


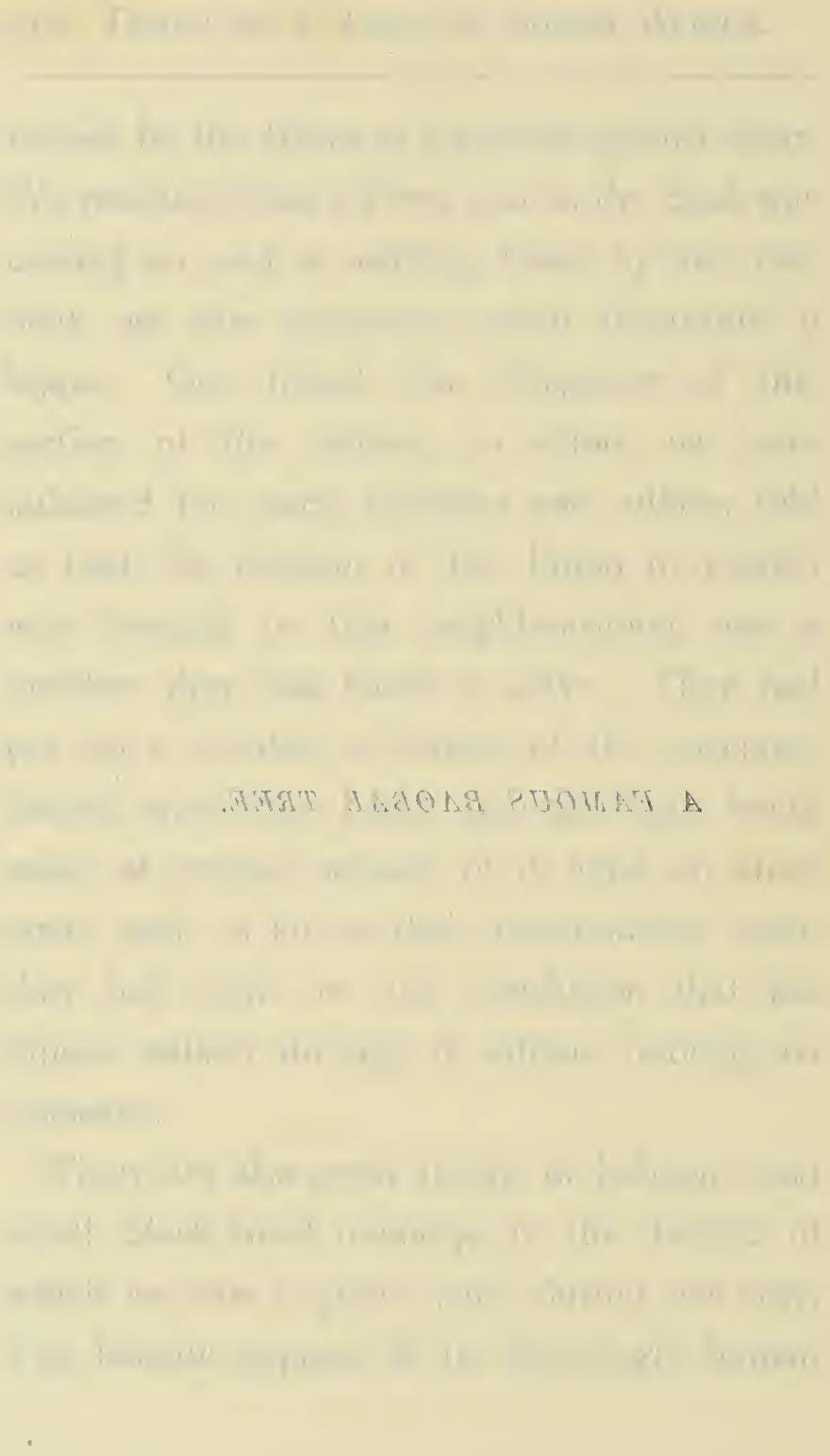




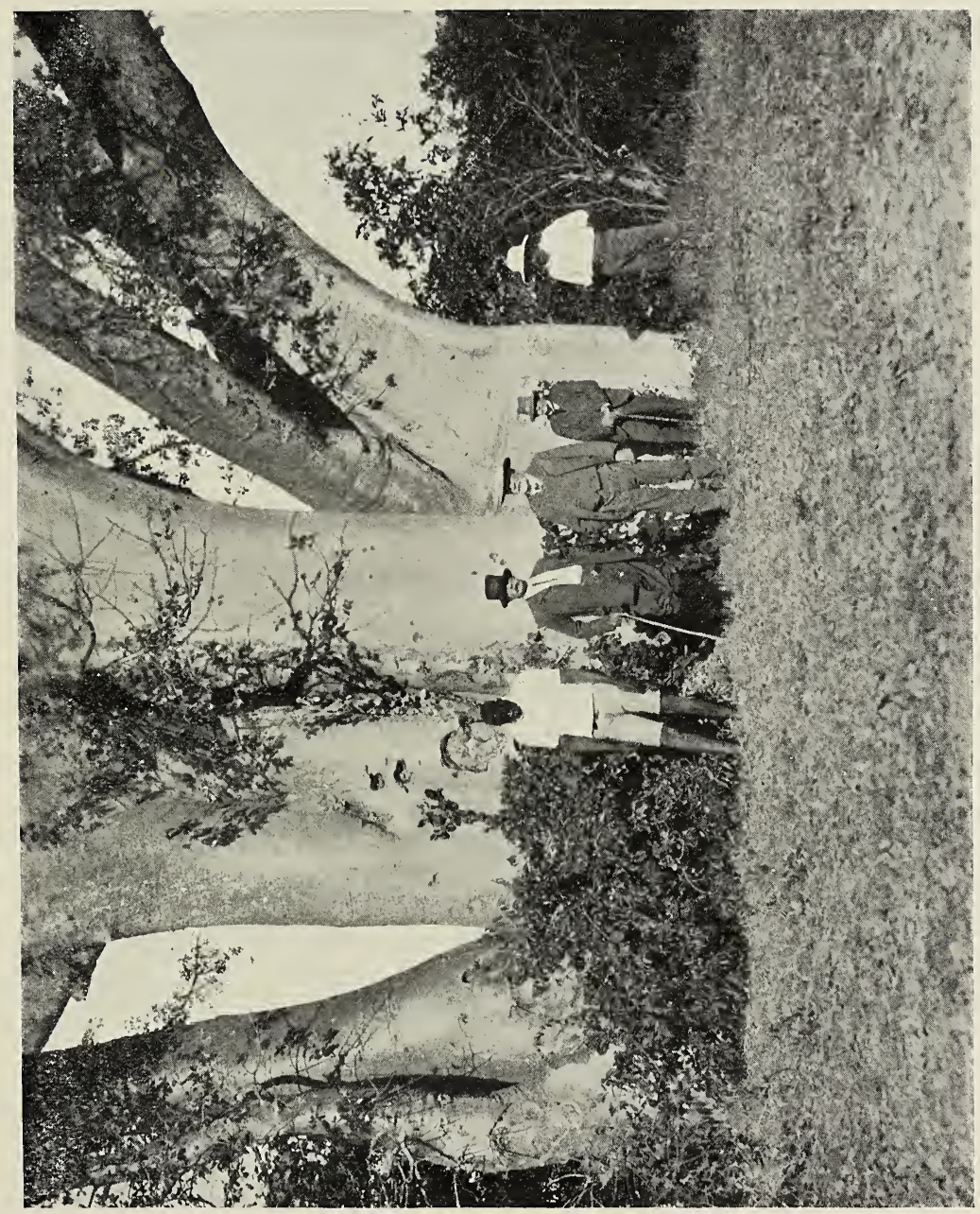


in many of its ways. A short time before our visit one biggish fellow had the audacity to seat himself on the tennis-court of the hotel, and was promptly shot by the manager, but only wounded. The brute made a dreadful jammer, and his chums came out of the bush and carried him away, but not before they had tried to extract the bullet. The manager told me that the scene was so human, he was sure he could never bring himself to fire again at a baboon.

During our stay at the Falls, we visited Palm Kloof, the Rain Forest, and many other points of interest. I have written more about the Victoria Falls than I intended, but my excuse must be that it is "a very large subject." Its fascination is great, and notwithstanding repeated visits extending over six days, it was with feelings of great regret that I repacked my trunk, dined for the last time in the hotel, and joined our car a little before I I.3O P.M., crossing the bridge about midnight. The trains 
148 Diary of a Tour in South Africa.

only just crawl over the bridge, and those were an impressive few moments we spent listening to the thunder of the waters in the darkness of the night. We reached Livingstone about half an hour later, and it was our quarters for the next twenty-four hours.

Miles from Victoria Falls, eight; and our journey since leaving Cape Town is now 4,804 miles.

\section{May 25.}

This morning, one cannot help feeling that after the impressive scenic grandeur of the past six days, the remainder of our trip must necessarily be more or less of an anti-climax. Still it is most interesting to be at last in NorthWestern Rhodesia, which province of the British South Africa Company's territories is separated from Southern Rhodesia by the river Zambesi.

It is not so very long ago that the district 
Diary of a Tour in South Africa. 149

which is now the township of Livingstone, where we find ourselves this morning, was not exactly a centre of civilisation! Now it has three hotels, a number of nice houses, public gardens, etc. ; and in addition, in about ten days it is going to have a Grand Regatta, at which many world-famous oarsmen will be present. To-day the place has got quite a Henley look about it, as parties of oarsmen are continually passing us on trolleys, by the narrow-gauge tram line which runs from the town down to the Zambesi. It is very, very hot here to-day sitting reading, and I've a fair idea of what it is like on the river, training for the regatta, and I certainly do not grudge the gentlemen in flannels their pastime. What with motor launches, steam launches, and racing eights, etc., Mr. and Mrs. Hippo and family are apparently in for lively times, the impression being that this annual regatta is likely to become a pretty big business in the 
i5o Diary of a Tour in South Africa.

near future. As the administration of NorthWestern Rhodesia is quite distinct from that of the southern province, I had to make my usual call on the Customs Department, and get new schedules filled in, although we were only to be three days in the province. The investigation turned mainly on how much of our stock of dutiable fluid we were likely to absorb while we remained. Well, the temperature was very high, and there was distinctly thirst in the air, and I assure my readers that for once I did justice to the prowess of our quartet of very moderate drinkers!

May 26.

Just after breakfast this morning we received a wire from Cape Town, saying that we can have berths on the S.S. Briton, sailing for Southampton on June 16 , and have just wired home saying they may expect us to arrive in England on July 3. We are now preparing to 
THE ENTRANCE TO THE GORGE. 


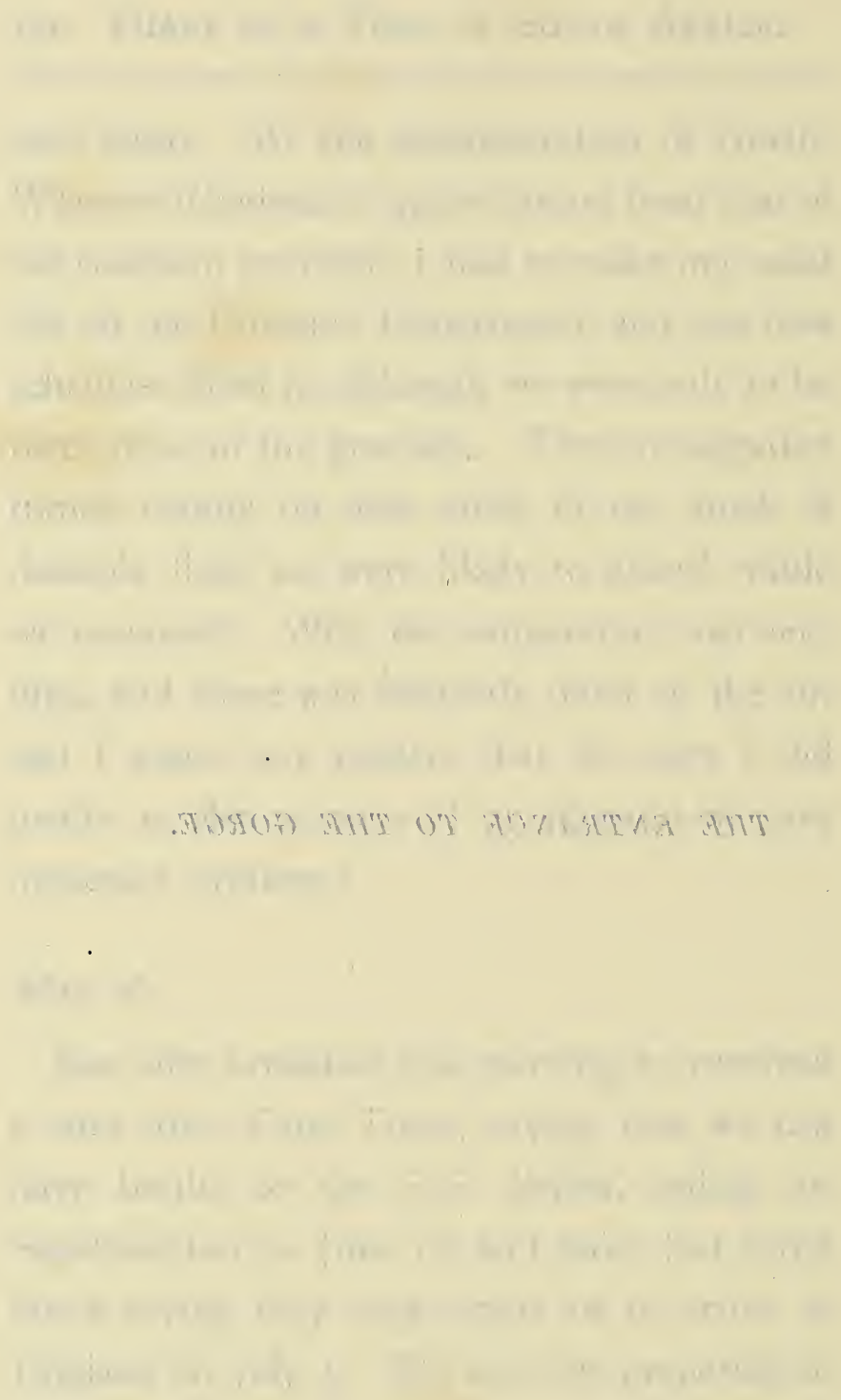




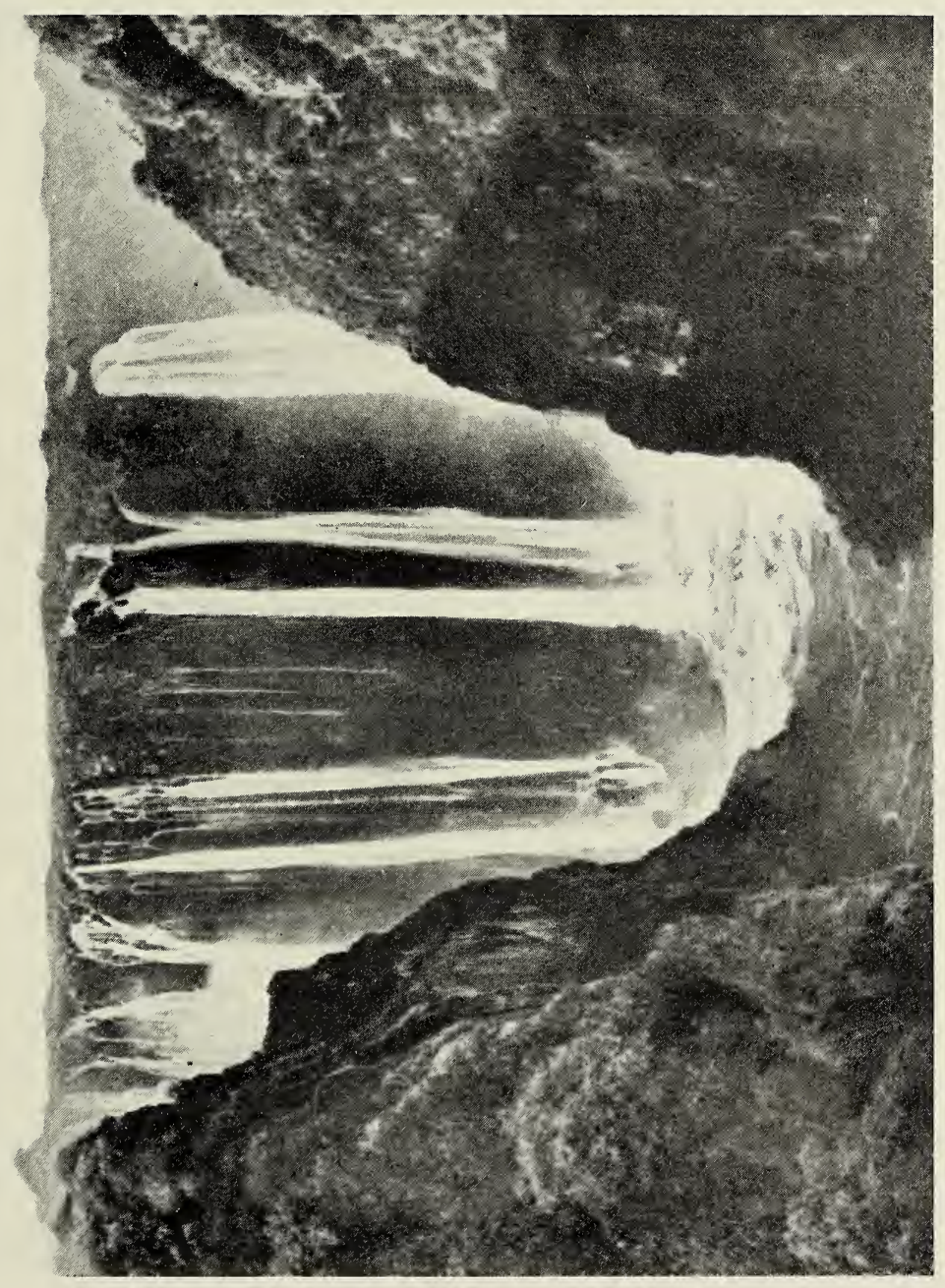



Diary of a Tour in South Africa. I5I

start on our journey still further north, which of course here means towards the equator. How far we shall get has been a moot question for some days past, as the River Kafue has been misbehaving itself, owing to the exceptionally heavy late rains, and has overflowed its banks, with the result, that a very large tract of country is inundated, including a portion of the railway track. Our friend the local Engineer has just looked us up to say that the latest news is, that we shall not be able to get beyond the river Kafue, but we need not fret much about this, as we understand that there is little variety in the journey to the Kafue, 260 miles distant, and the remaining I07 miles from thence to the rail-head at Broken Hill, is said to be particularly uninteresting. "Sour grapes!" a reader may remark, but I assure my friends that by this time, having lived in our car for nearly two months, and having travelled about 5,000 miles 
152 Diary of a Tour in South Africa.

in it, we were not feeling specially greedy about more mileage, when it only meant more dust and heat.

In the ordinary way there is very little traffic here, but just now there is a lot of railway material going up for the new extension of the line, and empty trains returning, and, with the breakdown at the Kafue, everything appears to be in a state of disorganisation, with the result that no one could tell us when we were likely to get a train that would take us on. However, a railway material train has just turned up, and they are going to couple us on to it.

We managed to get away from Livingstone about mid-day, our car being at the rear of the train, on the observation platform of which I was standing as we entered the forest. Suddenly from amongst the trees darted out a Barotse girl, who grabbed the carriage coupling and raced along with the train for 


\section{LIVINGSTONE STATION.}




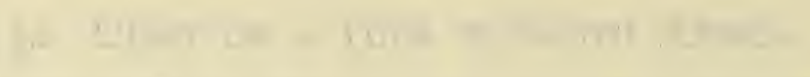

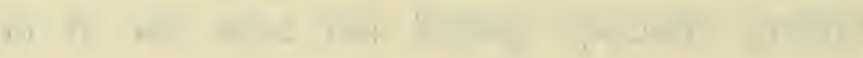

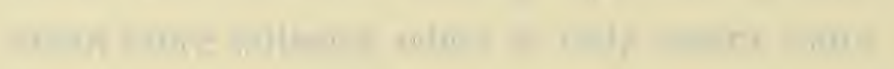

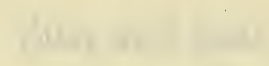

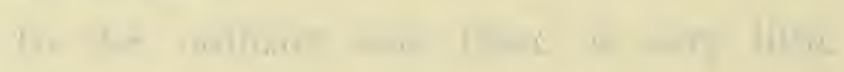

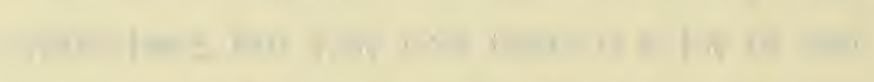

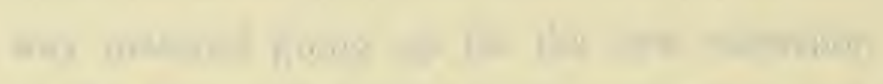

nit -i

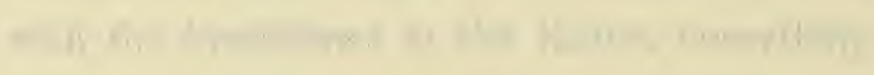

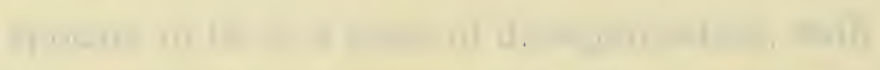

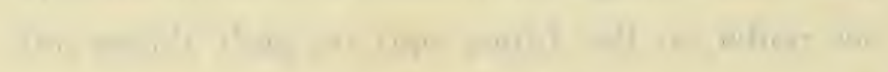

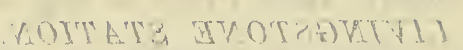

ringle

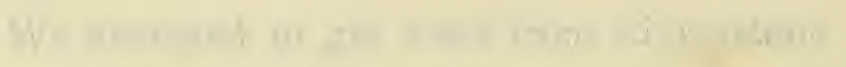

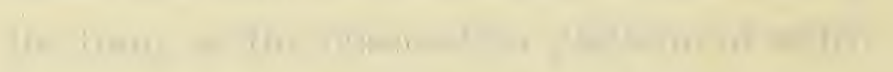

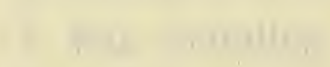

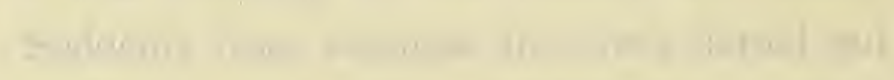

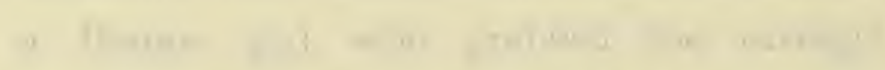

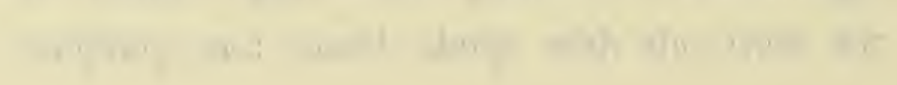




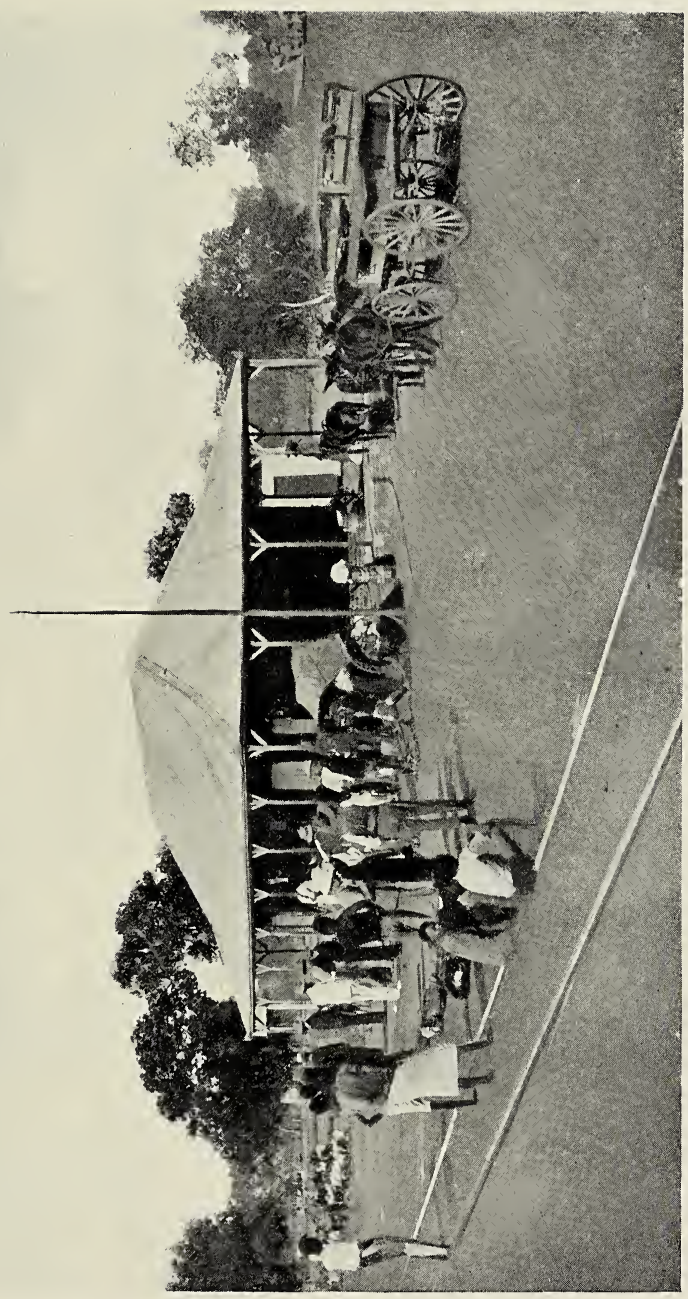



Diary of a Tour in South Africa. I 53

a long distance, yelling and singing with joy at the fun. My shout to my travelling companions to come and share in it scared her, as she had no idea, apparently, that she was observed, and she disappeared into the forest. Of course, it was a goods train, and we were ascending a gradient, but the speed was quite respectable, and that young woman must have been pretty sound in wind and limb, as she did not appear at all fagged.

Notwithstanding the reports previously received, we have found much to interest us during the first few hours of to-day's journey, but the fault is that it keeps on being just the same all day, and then one wearies. At 5.30 P.M. we reached Kalomo. This was the seat of Government of North-Western Rhodesia (Barotseland), but owing to repeated bad outbreaks of malaria, it was removed to Livingstone a year or two since. It is a very small township, Ioo miles north of the Victoria Falls, 


\section{i 54 Diary of a Tour in South Africa.}

and 5,000 feet above sea level. Had we arrived here about six weeks later, our party, we were told, could have had excellent shooting in the district. We were delayed here for over an hour for no apparent reason. Probably the locomotive had been short of water when we arrived, and doubtless we had to wait till the new supply reached boiling point. By the time we started again, it was getting dark, and anyhow we had seen quite enough of teak forests, with an undergrowth of tall elephant grass, for one day, which finished in the usual fashion with dinner, smoking, and bridge, as we forged our way into the night through the interminable forest.

May 27. Kafue River.

Miles from Livingstone, 260; and since leaving Cape Town, total, 5,064 miles.

Our friend the engineer was quite right. We shall get no further than this. We arrived 
THE FLOODS AT THE KAFUE RIVER. 



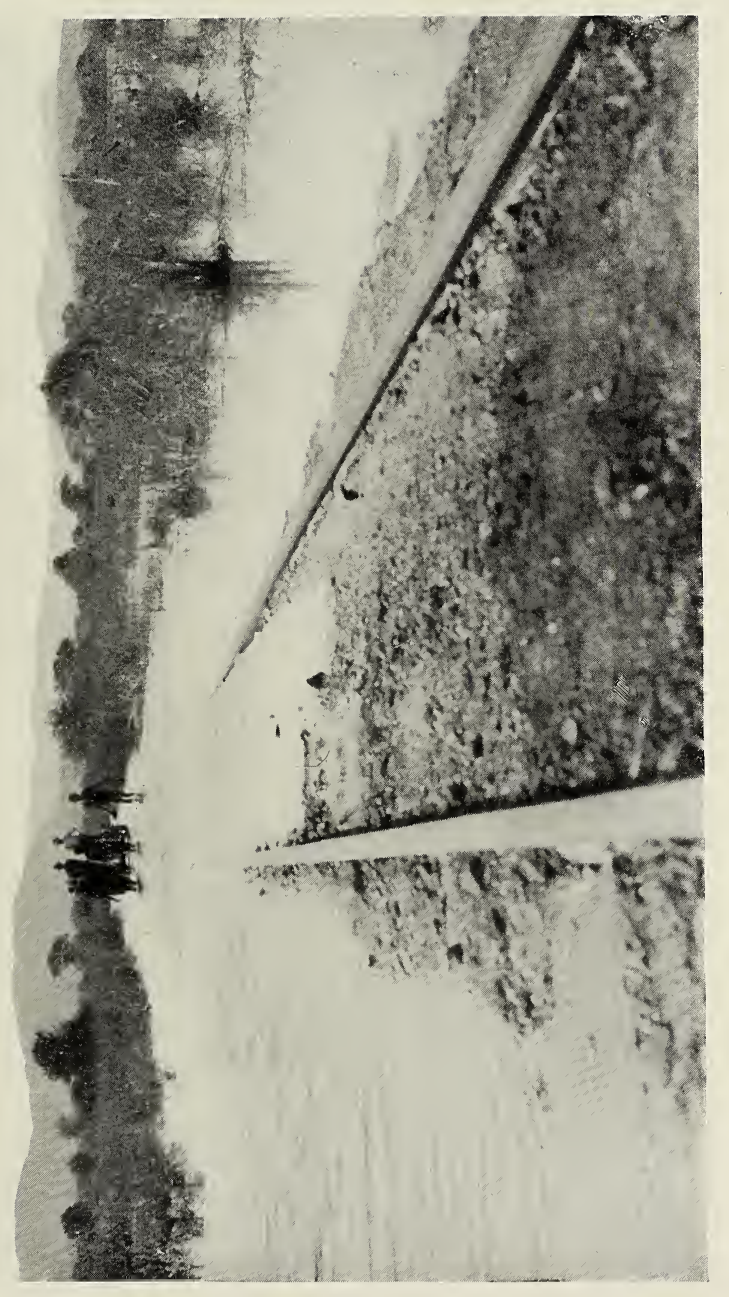



here this morning at 8.30 , and things generally are very decidedly in a regular mess. For some days past they have been working the railway material through, by making up a long train of trucks, with locomotives at the rear end to push them through the flood until others can get hold of them at the front end, the water being too deep for the engines to go through. The passenger traffic has been stopped for some days, and as it is thought that the flood will not subside for some time yet, the railway authorities have decided to raise the line where the flood is worst, hence, there is no traffic to-day, nor will there be, we are told, for a few days. We have had the chance of going through in a boat, but if we do so, we shall have to remain here for another thirty-six hours with nothing to do; and as we are surrounded with what is nothing more or less than a huge swamp, it has been decided that the sooner we steer south the better. We 
I56 Diary of a Tour in South Africa.

have heard that some empty trucks are leaving this morning, so we shall depart with them.

This is really a scene of great confusion, all sorts of railway material being deposited in great heaps all over the place. There are also scores of natives on their way up to work at the extension beyond Broken Hill ; but these, I understand, will get through in boats, of which I only saw one, so that will not be a very rapid proceeding.

We got away from this scene of disorder about eleven o'clock, the train consisting of the locomotive, two empty trucks, and ourselves-not a very imposing procession through the Rhodesian jungle; but we were very glad to get anything to haul us away from that swamp before dusk, bringing with it the attentions of the myriads of mosquitos that we understand were keeping carnival over the inundation. 
This time we are getting the stretch of country by daylight, that we passed through in the night on the up journey. The scenery was much the same, but an enormous number of huge ant-hills was a particular feature of it.

\section{May 28.}

We got back to Livingstone this morning at seven o'clock, and spent a quiet morning, for which we were duly thankful, after the past nearly two days, and two nights, of almost continuous jolting and dust.

About mid-day we were able to get across to Victoria Falls, and some of us had a last look during the afternoon, but although it was the last look by the light of day, we have been again this evening to get a glimpse by moonlight, which is very beautiful, but also very weird, the weirdness of it being rather intensified by the thought of that hippo which had 
I58 Diary of a Tour in South Africa.

charged, and badly mauled a tourist sitting on a fallen tree, admiring the beauties of the place, some three weeks previously. As we lingered on the edge of the Rain Forest, I caught myself more than once glancing suspiciously over my shoulder at the weird shadows, and listening for that heavy foot-fall.

Miles from Kafue River, 267; and since leaving Cape Town, 5,33I.

\section{May 29.}

We have had a nice quiet night in the car, and are now waiting for the Zambesi express to pick us up and take us on to Kimberley, a through run of 993 miles, to do which we shall be running from mid-day to-day (Saturday) till midnight on Monday, which works out at about sixteen miles an hour, including stoppages. These, although not numerous, are fairly prolonged. The actual rate of travel of the 
Diary of a Tour in South Africa. I 59

Zambesi express is about twenty-five miles an hour.

We got away from the Victoria Falls station just about mid-day, and reached Wankie (of coal fields fame) a little before sunset. It was most interesting to suddenly emerge from the perpetual forest, and find ourselves surrounded by all the "picturesque" paraphernalia of a coal district. Lots of people of both sexes had come to see the link, which twice every week connects them with the outside world. We made a stop of nearly an hour, and by the time we entered the forest again it was almost dark.

\section{May 30.}

We reached Bulawayo this morning at 7.30 -280 miles from the Falls, and 5,6 I I miles since leaving Cape Town-and after leaving Bulawayo, my note book says: "Tedious, dusty, uninteresting day." 
i60 Diary of a Tour in South Africa.

\section{May 31.}

We got up this morning to view precisely the same scenery, or rather absence of it, that we had last night at sunset, and similar clouds of dust, but since breakfast we have had several diversions.

I omitted to say, that just before we left Bulawayo yesterday, we received a message from the traffic superintendent, saying that our car appeared not to be in very good running condition, as there was a very decided sinking towards the centre (which we ourselves had already observed), the result, probably, of our huge quantity of luggage and general stores, (bottles always do weigh a lot)! Of course we have been running now continually for two months, during which time the car has never had a chance of going into dock, and, doubtless, there are by this time lots of loose bolts and screws that want tightening up. However, they let us go on with the Zambesi express, 
A SUMMER RESIDENCE IN THE RHODESIAN FOREST. 


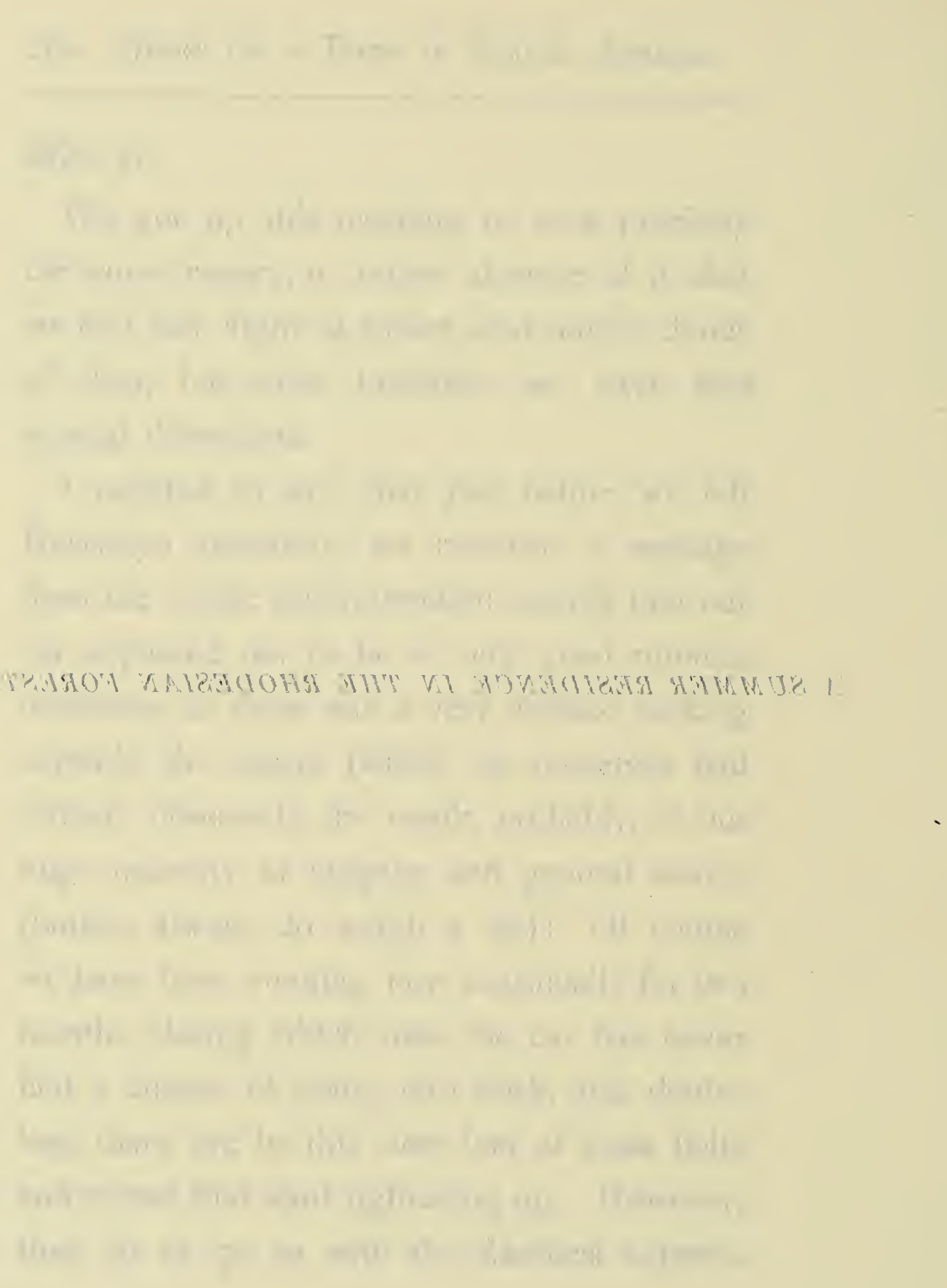




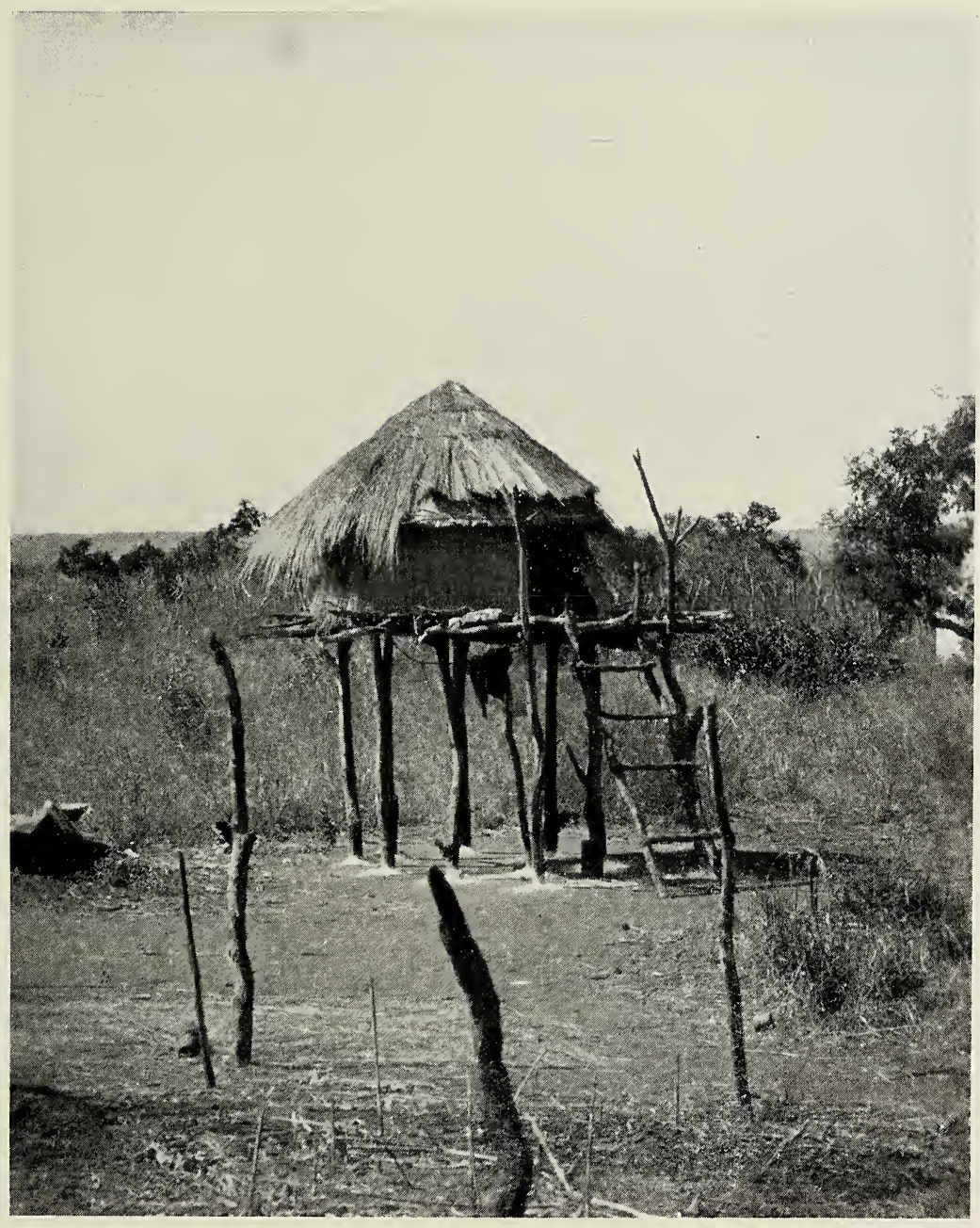



Diary of a Tour in South Africa. i6I

but sent a mechanic with us, to see how the car would behave during its journey to Mafeking. The said mechanic didn't do much besides pay us a visit en route, and was received in the dining-room, where he wearied us for a long time with yarns of what the car might do.

Like most of the railway men up country, he was a Scotchman, and doubtless the human contents of that dining-room, made it seem for the time being like a little bit of Scotland, the illusion being probably completed, when Guntrip was instructed to see that he got a dose of the famous Highland medicine, which we always carried with us in case of accidents. The things our Scotch friend had said might happen, didn't, but shortly after breakfast we felt the brakes go on with rather a jerk, and we came to a sudden halt, followed by a racing up and down of the train officials, to see what had gone wrong. The mischief was after a while located in our section of the vacuum 
brake, where it was discovered that some small cap had become unscrewed and lost itself. Guntrip with great presence of mind provided the officials with a cork (of which there were generally a few to be had in the car) and a piece of string, and the damage was soon repaired, the Train de Luxe from the Zambesi proceeding on its way rejoicing!

Not, however for long as we felt the speed of our train gradually becoming less and less, and we trembled inwardly for the efficiency of that cork and string arrangement, or fancied that some of the fears of our Scotch friend were about to be realised, but it was nothing so startling. It was merely that the last tank we had stopped at for water was found to be dry, and that the locomotive had not sufficient steam to take us any further, and we were still fourteen miles from Mafeking, and the next water supply. After a short stoppage to try and accumulate a little steam, the driver had 
Diary of a Tour in South Africa. ${ }^{16} 3$

another try, but we only moved a few yards. Then he uncoupled his engine, which could fortunately get along all right alone, and it was not long before it vanished in the distance, most of the passengers getting out of the train to stroll about on the Veldt, and amuse themselves as best they could, until another engine should arrive to rescue us, which it did in about an hour and a half, and we then proceeded on our way to Mafeking, arriving there two and a half hours late.

Shortly after our arrival, the Mafeking stationmaster came to the car, and told us that as he had information that our car needed some repairs which would take several hours to complete, he was going to take it off the train, and we could continue our journey to Kimberley the next day, attached to a "goods" train, a piece of information which our Chiefs did not swallow with quiet Christian resignation! 
i64 Diary of a Tour in South Africa.

However, the pending row did not come off, as we discovered that our old acquaintance, Sir Charles Metcalfe, was in the train, and he very kindly came along and had a look at the car, and certified that it was quite fit to go on to Kimberley, when it could be overhauled, as we intended to stay there a couple of days. It was a piece of luck Sir Charles was in the train, he being the designer of the car, otherwise we should have stuck at Mafeking, and there certainly would have been "words!"

This talk about the car recalls an episode in Zululand that I have not chronicled. Certainly the car had one grave defect, it was built very low, which would have been of no consequence had there been nothing underneath. Below the car floor, we carried a dynamo and a great lot of accumulators, enough to store current for three days when we were not running, also any number of lockers which we had filled with cartridges and stores of all 
Diary of a Tour in South Africa. 165

kinds, and I am quite certain that often there was only a few inches between all this stuff and the ballast. On that journey into Zululand, between Durban and Ginginhlovu, there were no inches at all, as on our arrival there we found that our dynamo had struck the ballast sometime during the day, and had completely vanished.

The result of this little accident was that for some days we were reduced to lamps burning petroleum, in the roof, "cleverly" constructed, so that you could neither lower nor raise the light, once they were fixed in the roof; consequently, they were always turned too low, or too high, and smoked the glasses, the net result in either case being, that one could barely see to eat, let alone read. We had rather a long dose of this arrangement, as, owing to the railway strike then in progress in Natal, we could get no repairs done in Durban, and it was five days later when we 
i66 Diary of a Tour in South Africa.

reached Johannesburg, before we were able to get a new dynamo fitted.

But to continue our journey. We left Mafeking at mid-day, and arrived at Kimberley at midnight, and nothing of interest happened en route.

Miles from Bulawayo, 7I3; total travelled from Cape Town, 6,331.

June I. Kimberley.

Our prolonged career of sight-seeing is now drawing to a close, and we have seen most that South Africa has to show us, with the exception of the diamond industry. As we are all fairly tired, we are leaving the diamonds alone to-day, and are having a quiet look at the town, which owes its existence to their presence, and dates from about 1870, when the first stones were discovered. The estimated yield of diamonds to the present date, exceeds 
Diary of a Tour in South Africa. 167

twelve tons in weight, of the value of some eighty millions sterling. To-day we have lunched in the outskirts of the town at the Belgrave Hotel, formerly, we understand, the Kimberley Sanatorium, which certainly had more of the sanatorium than hotel look about it, but we have found it so comfortable that we shall probably pay it another visit to-morrow. Traces of the siege are still to be met with in the shape of galvanized iron fencing, riddled with bullet holes.

Kimberley has a good supply of water from the Vaal river, seventeen miles distant, but the simple methods of gravitation that we are accustomed to in Scotch towns, are conspicuous by their absence, as Kimberley stands 500 feet above its source of supply.

We have a comfortable anchorage just outside the station, and have dined in the car as usual to-night, as none of us cared to go out. 
i68 Diary of a Tour in South Africa.

\section{June 2.}

We have had a very cold night, but as it is now nearly mid-winter, and we are 4,01 2 feet above sea-level, I suppose we need not greatly marvel.

Since breakfast we have been enjoying a most lovely, cool, pleasant day, with no wind, and its correlative, no dust. Going first of all to the De Beers' office, a pass was obtained to view the Wesselton Mine, situated rather more than a mile from the town. Arriving at the entrance gates, we found after a short wait, that we were to be taken round the works on a sort of trolley, running on a narrow gauge railway. The trolley was drawn by a couple of mules, and the De Beers Co. also provided a competent guide.

We saw, first, the large tracts of country fenced in with barbed wire, called "floors," where the blue rock after quarrying, is spread 
THE WESSELTON DIAMOND MINE (DE BEERS), KIMBERLEY. 


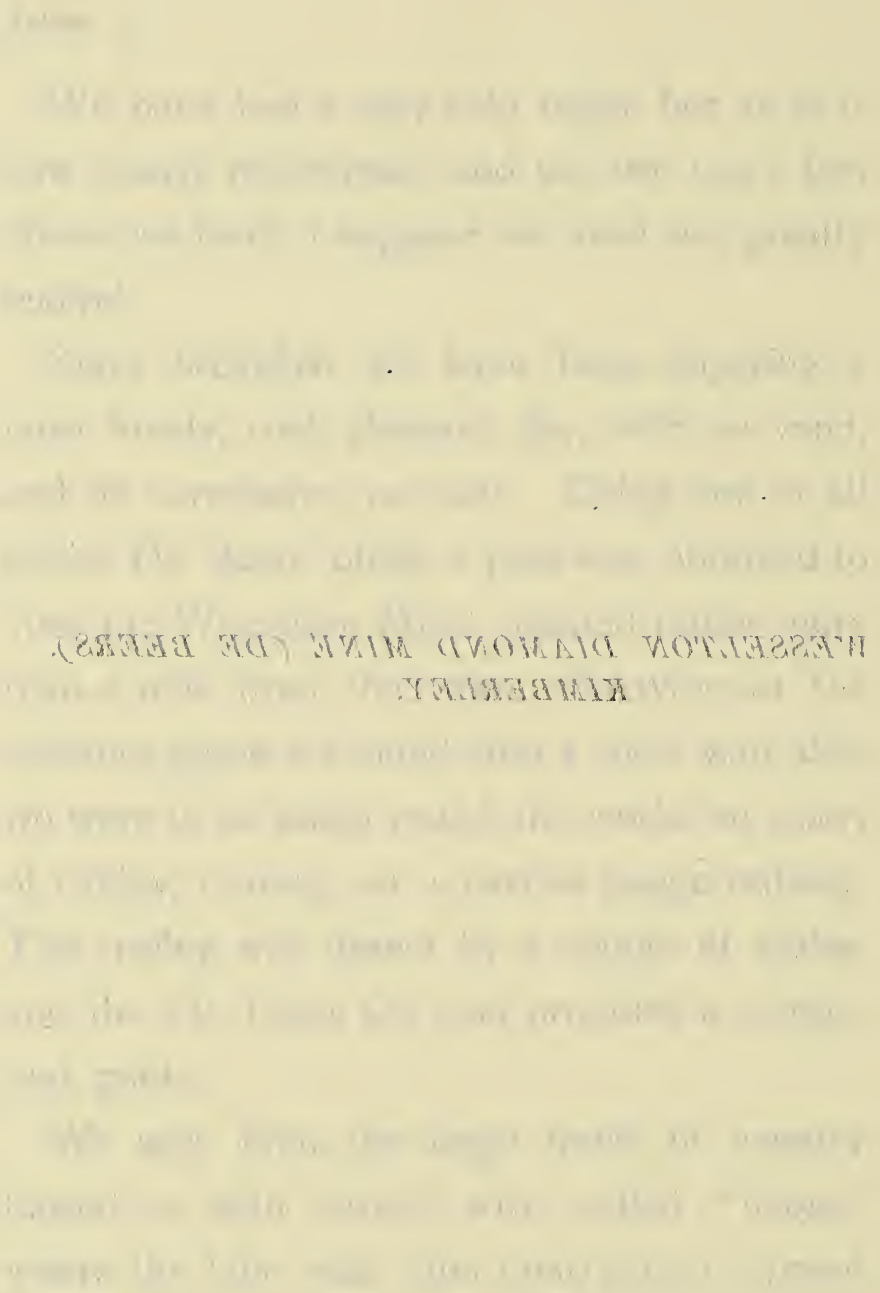




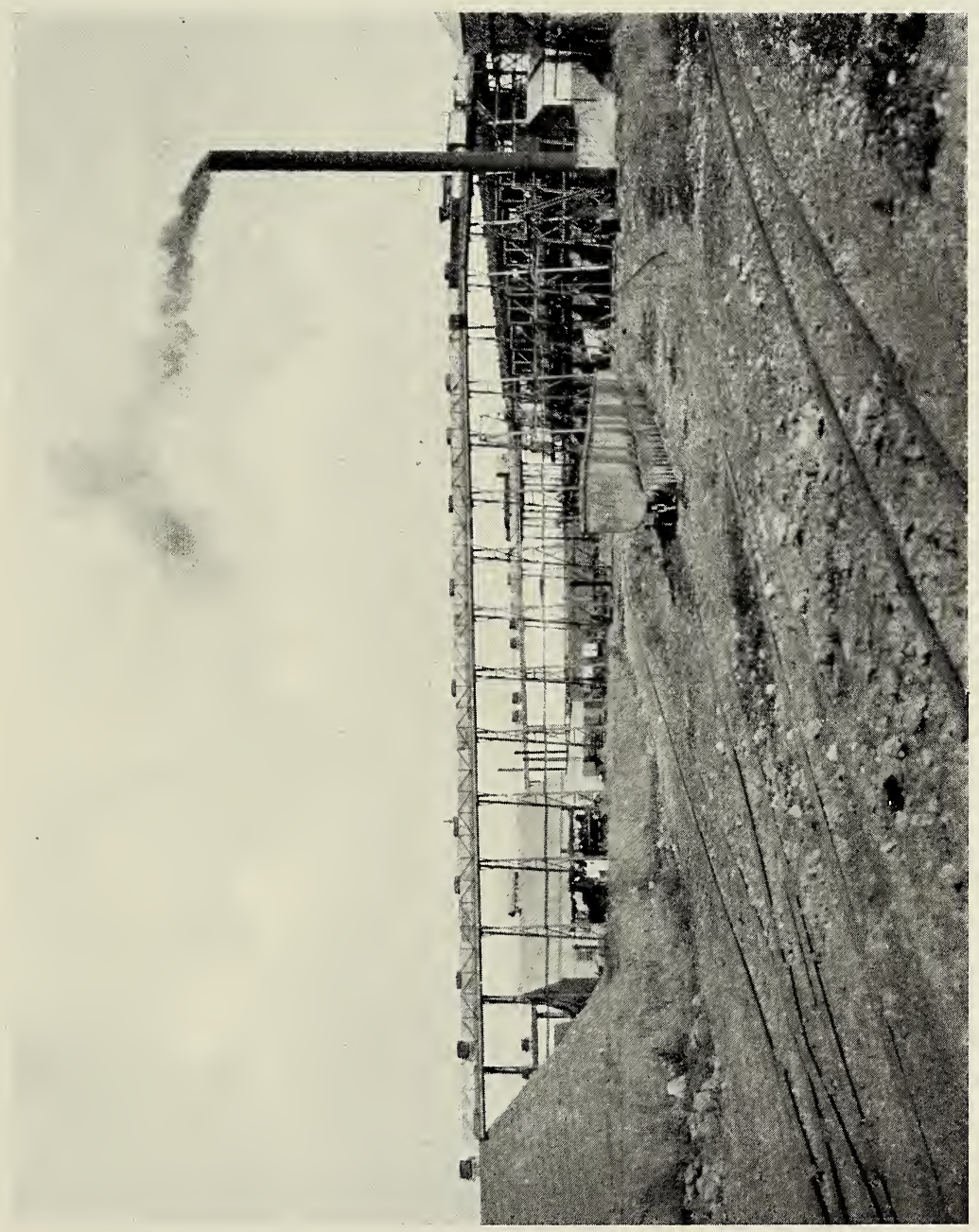




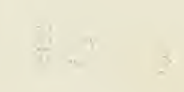


Diary of a Tour in South Africa. i 69

out to disintegrate by the action of time and weather. It remains exposed a long time on these floors, before it is fit to be worked by the washing machinery. I forget exactly how long our guide told us, but my impression is that it was considerably more than a year. We also passed enormous heaps of hard lumps of blue, which had refused to disintegrate under the peaceful influence of time and weather, and for its treatment the De Beers Company now employ crushing machines.

We brought a few bits of this blue rock home, but so far I have not heard that any of our party have done any successful crushing!

It was most interesting to watch the apparently endless procession of trucks of blue earth coming up from the "floors" to the washing gear. This latter process resembled the making of gigantic mud pies; and in looking at the horrible mess presided over by grimy Kaffirs, even with knowledge, one needed some im- 
i 70 Diary of a Tour in South Africa.

agination to connect the scene in any way with the flashing brilliancy of a gala night at the Opera. Before we finished our inspection we looked down into the quarry, which is too enormous to describe. It has become too large and deep to work any longer from the outside, and the blue ground is now being brought up a shaft alongside, after the manner of a coal mine.

By this time we had had about enough of the diamond industry. After lunching again at the Belgrave Hotel, we spent the afternoon sightseeing.

The principal objects of interest are the Siege Memorial, and the fine avenues constructed during the siege, the expense of which was borne by Mr. Rhodes and the De Beers Company-relief works for the natives being necessary, owing to the closing down of the mines. An interesting relic of the siege to be seen at the Memorial, is the long-range $4^{\circ}$ I gun 
Diary of a Tour in South Africa. i 7 I

made by Mr. Labran of the De Beers works, who was killed by a shell shortly after its completion.

As on many former occasions the luxury of seeing South Africa from a private car was again very apparent to-night, as we were able to dine comfortably at seven o'clock, afterwards having a few games of bridge, and then turning in for the night at about eleven, having given instruction to the stationmaster to have us coupled to the train leaving at 12.40 A.M. for De Aar Junction.

June 3 .

De Aar Junction, I74 miles from Kimberley, and 6,478 miles since we left Cape Town.

We came on to this place coupled to the train coming down from Bulawayo, but we have decided to wait here all day, though there is really nothing to see, in order that we may be coupled to the Johannesburg express arriving 
i72 Diary of a Tour in South Africa.

this evening, en route for Cape Town, so that by this means we may see the whole of the Hex River Pass by daylight, which we had failed to do on our journey up. Fortunately, we got our English mail this morning, and this off day has given us a good chance to get some home letters written.

This is a most uninteresting place, but is an important railway junction, and is well known to everyone as one of the most important advanced bases held by the British in the last Boer war. It still bears traces of it, as during a walk in the afternoon, we found numbers of empty sardine and preserved meat tins strewn in every direction over the veldt. Although the district is at an altitude of over 4,000 feet, we found it fairly hot tramping about the veldt on a mid-winter day, and could realize to some extent the discomforts of heat, dust, and thirst endured by the brave fellows encamped there, 
Diary of a Tour in South Africa. 173

under the rays of a scorching mid-summer sun, a prelude to worse things to follow.

To-night we are leaving at 7.40 for the last stage of our long ramble through arid plains and dusty towns; and after having lived at altitudes ranging from 3,000 to 6,500 feet for the past nine weeks, we shall in the course of the next twenty-four hours drop down again to sea level.

\section{June 4 .}

Just as we sat down to breakfast this morning the train drew up at Matjesfontein, the place at which we spent a Sunday on the up journey, and we were hardly at a standstill before our old friend Jamie Logan, the local "Laird," came over from his house to pay us a parting visit. The remainder of this day has stamped itself upon my memory as being full of ever changing scenic grandeur. We have, un- 


\section{i74 Diary of a Tour in South Africa.}

doubtedly, struck the Hex River Pass this time on an ideal day, and as they don't risk bringing the train down those fearful gradients at any greater speed than they crawl up them, one has ample time to see all the beauties of the lovely valley and snow-clad mountains. When some twenty miles from Cape Town, we got a good view of the back of Table Mountain, and a short time afterwards found ourselves once more in Cape Town station, having travelled 500 miles from De Aar, and 6,978 miles since we left this spot.

As there are still a few places to visit by rail in the neighbourhood, it has been arranged that we remain in the car for the next few days. On our arrival we were met by Mr. Andrew Coats and Mr. Armour, and shortly afterwards we were given a good anchorage for the night just outside the station. I don't suppose it will be very quiet, but we are old stagers at this game now, and don't seem to 
Diary of a Tour in South Africa. 175

notice the rumble and rattle of heavy goods trains, or the screams of locomotives, and shall sleep, doubtless, as usual, quite peacefully.

\section{June 5 .}

After our long sojourn on the high veldt, one feels an unaccustomed mildness in the air down here at sea level, and Cape Town this morning reminds me very much of a warm early autumn day on the Clyde, and one forgets that in a couple of weeks or so it will be the depth of winter here. If this is a sample of Cape Town in winter, it is truly a delightful climate. During the morning we arranged to take the car down to Simon's Town for the week-end, and left about two o'clock-which place, about twenty miles distant, we reached in about an hour.

We have got excellent quarters for the car on a siding close to the sea, which, however, is not likely to tempt us to bathe, although it 


\section{i76 Diary of a Tour in South Africa.}

looks very enticing; the presence of a stray shark or two is not uncommon hereabouts. Simon's Town, being on the Indian Ocean side of the Cape Peninsula, its tempting waters, we understand, are never considered safe from the presence of these fishy horrors.

But at this moment we are more concerned with our own domestic arrangements, as there is a fiendish row on in our kitchen. The little coloured imp who assists Monsieur le Chef in that department, has again got tolerably drunk, presumably on the balance of the proceeds of his nefarious Kimberley bottle transaction, and Mons. le Chef has kicked his bibulous assistant out of the car, and thrown after him all his worldly belongings wrapt up in a coloured handkerchief of very moderate dimensions. At the present moment the "Rev." Auguste Soles, that is the youth's name, sits enthroned upon a heap of ashes.

This is no place for the life story of Auguste 
INDIAN OCEAN. FROM SCHUMACHER'S KOP, PORT ELIZABETH. 


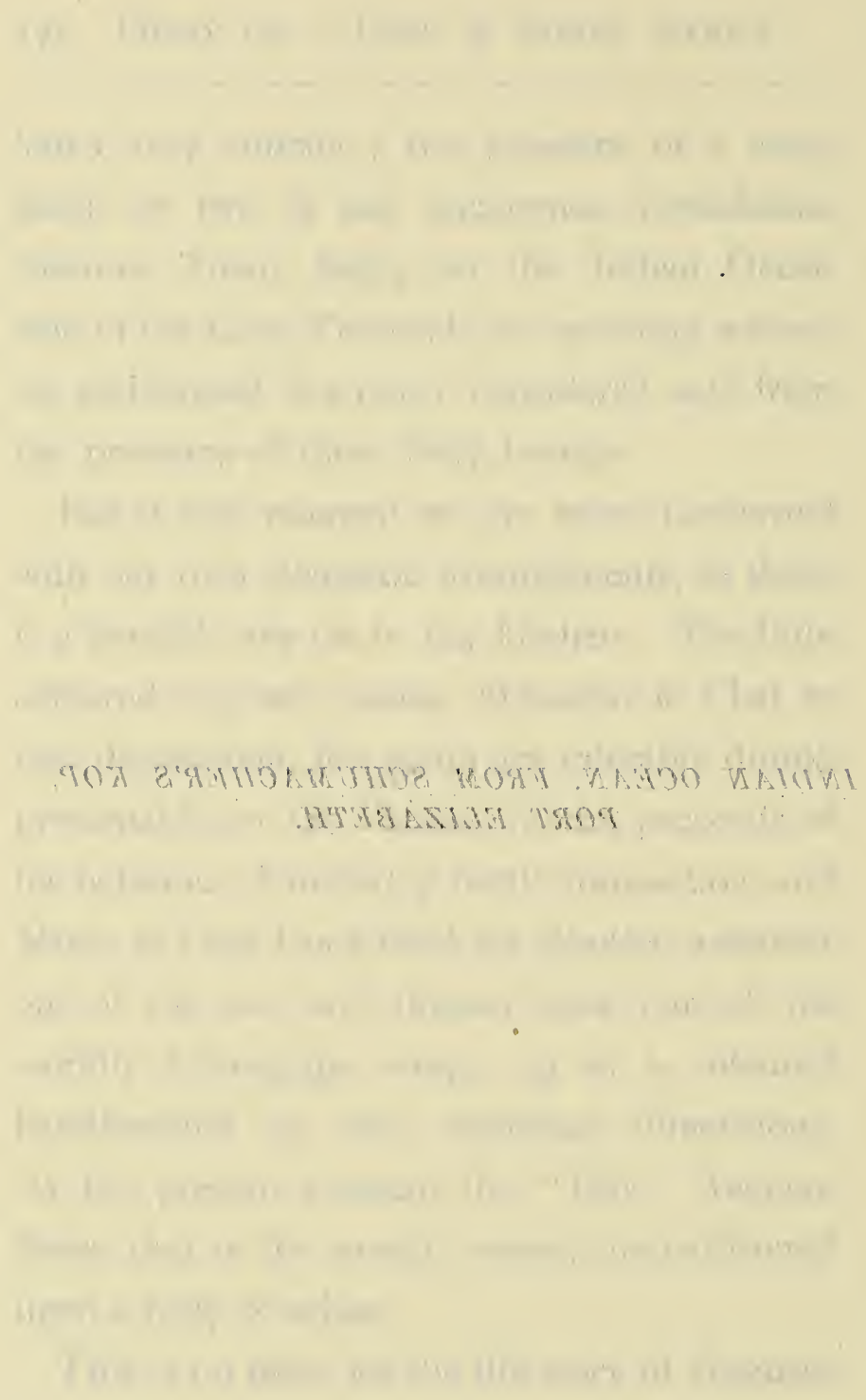




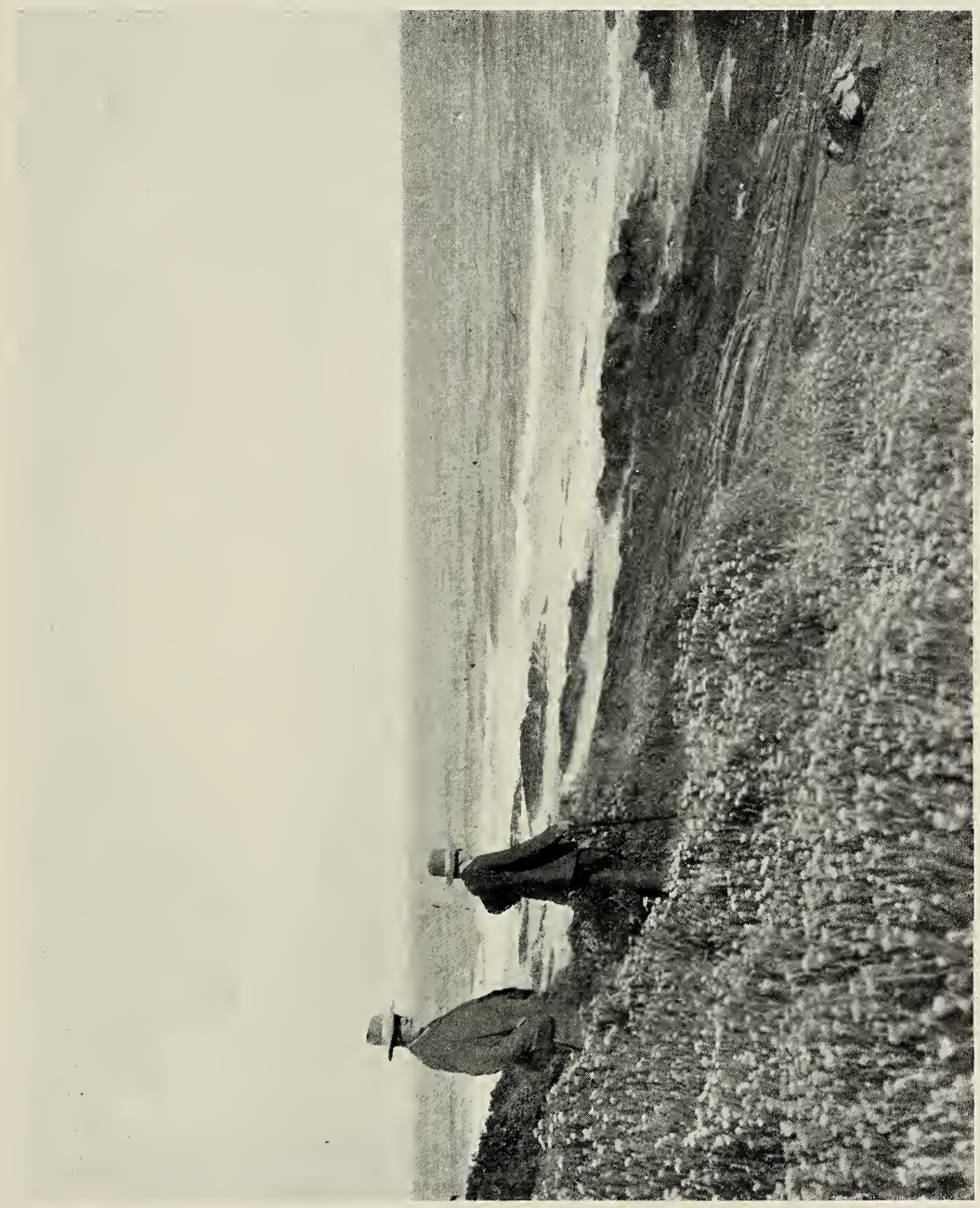



Diary of a Tour in South Africa. i77

Soles, but a few phases of it that touched our own lives, may be of interest to the student of coloured humanity. He started with us on our travels, to all appearances a simple, little, one-eyed Kaffir boy. His tastes were said to be simple, and we were told that at night (as no bed had been provided for him) he would make himself quite comfortable on the kitchen floor. But that little black Soul soared to higher things, and the second night out he was discovered asleep in the "seats of the mighty." Somehow or other the Laird seemed from the first to have a suspicion, that our young friend might find a softer spot to sleep on than the kitchen floor, and sometime during that second night out he got up to have a tour of inspection. On entering the dining-room, he saw spread out a dirty hat, coat, and waistcoat on the dining table, and that little black depository of millions of fleas actually asleep on his, the Laird's own particular seat! As far as we 
i78 Diary of a Tour in South Africa.

could gather next morning, both parties to that transaction, which I believe was a moving one, were extremely agitated, and we all wished we had been there.

I don't quite know where that title of "Reverend" came from, but think the Professor was responsible for it; anyhow, it stuck, and after this, the complex character of our coloured chaplain, as we used to call him, developed by leaps and bounds. We soon found out that the reverend gentleman had a wife and two children at Cape Town. Unfortunately, the wife had gone off with another Kaffir, but our young friend seemed to be bearing up very well under the heavy load of his domestic sorrows, and had always a cheerful grin for us on every occasion. He was an expert artist on the tin whistle, and many a night on the lonely veldt he sat out in the darkness, and played hymn tunes that he had learned in a Mission School, and also some Scotch 
Diary of a Tour in South Africa. i79

airs, I suppose as a compliment to what he had got in the car. The "Rev." Auguste could speak good English, also Dutch, and I suppose Kaffir, and could write letters in both of the former languages.

His really great achievement on the trip was the Kimberley bottle trick before mentioned. At an early stage of the trip, he had humbly craved permission to retain all the empty bottles that were constantly being thrown out of the car, the result being that by the time we reached Kimberley, he had gathered a fine collection. On arrival at Kimberley, he had sold them to a brother Kaffir bottle-merchant, and promptly got drunk on the proceeds. Later on the Kaffir merchant came for his bottles, but as Mons. le Chef knew nothing of the transaction, he chased him away, and as we left shortly afterwards for the south, our car not only contained the drunken Auguste, but also every blessed bottle that he had sold. 
i8o Diary of a Tour in South Africa.

Having catalogued some of the virtues of our coloured chaplain, I now come to the sin of Forcioli, our intrepid Chasseur d'Afrique, otherwise Monsieur le Chef. This afternoon, he, after the kicking out of Soles, began to shew signs of restiveness, brought on by the proximity of Cape Town, and, in a solemn interview with the Professor and myself, aired his grievances, which, though lengthy, were purely imaginary, and in reality as we were well aware, were attributable to the fact that he had been carted down to Simon's Town for a dull (to him) week-end, when our arrival in Cape Town on a Friday evening had probably encouraged him in the belief, that a week-end carnival in the latter place, after his long absence up-country, was a matter of certainty. However, in his list of grievances he did not mention this. As Forcioli had been a very faithful and efficient chef all these past weeks, it was with some astonishment 
Diary of a Tour in South Africa. i8I

that we received the announcement that he intended there and then to "chuck up his job!"

As our hosts intended to finish with the car on the following Friday, the Professor and I told him he was a silly fellow (I think the terms employed were " $d \times x \times x d ~ f \times x l$ ") as, if he continued to behave himself, he would in all probability get a thumping big tip, not that his wages of $£_{4}$ a week could be considered slight remuneration for his professional services. Well! the end of it was that he seemed to agree with us, and dinner took place as usual, but in the course of the evening it was whispered round the car that Forcioli had decamped. At this stage the Professor and I decided that we could no longer keep the dread secret to ourselves, and that at all costs it must be broken to our hosts.

And now came the brilliant triumph of our versatile chaplain, who by this time was fairly sober. The reverend gentleman was hauled 
off his ash heap by Clark, our steward, and installed as Chef-in-Ordinary to the expedition, and I have pleasure in stating that our meals were served during the week-end in much the same style as usual.

Whilst our interview was going on in the afternoon with the chef, Mr. Dan had gone for a walk, and the Laird was having a nap, and when the former returned, he told us that he had been hailed in the main street of the town by two men who told him they were also from Paisley, and were engaged putting up the pumping machinery for the new dry dock. They were employees of Messrs. Fullerton, Hodgart, \& Barclay, and had been engaged on the work for some months, and had been greatly delighted to unexpectedly meet a citizen of Paisley. It has therefore been arranged, that we visit the dock in the morning.

Miles from Cape Town, 23; total by rail, 7,001 . 
Diary of a Tour in South Africa. i 83

June 6.

When we emerged from our home beside the sea this morning, we found charming weather conditions and every promise of a good day. Soon after breakfast (the hour of which need not be mentioned), we started off to keep an appointment with those Paisley men. We found them ready to start, and we were soon in the dockyard, where is situated the new graving dock, an enormous structure capable of taking any ship afloat. After viewing the dock, we were taken to see the pumping machinery then in course of erection, all of which was of much interest, and occupied us the whole morning.

By the time we got back to the car for lunch, a change in the weather appeared to be hurrying up from the direction of Cape Agulhas, the dividing line between the Atlantic and Indian Oceans, and by the time we had finished our meal, it was blowing hard and raining in tor- 
i 84 Diary of a Tour in South Africa.

rents, which it continued to do for the rest of the day. The only other event of this day was the return of our runaway chef, by the last train from Cape Town! As on the whole he was a decent sort of man, no notice was taken of his delinquency.

\section{June 7 .}

The patter and splash of heavy rain on the roof of the car reminded us as we wakened this morning, that high altitudes and arid veldt were things of the past, and that the proximity of the ocean and its results and effect were similar -be it Gourock or the Cape Peninsula. It certainly looked like a soaking day, but by twelve o'clock it had cleared, and in the afternoon we had a beautiful drive by the coast to Miller's Point, from which place we could easily follow the entire coast line to Cape Point some twelve miles distant, the lighthouse of which stands 840 feet above the water level. 
VIEW OF CAPE POINT (CAPE OF GOOD HOPE), FROM MILLER'S POINT. 



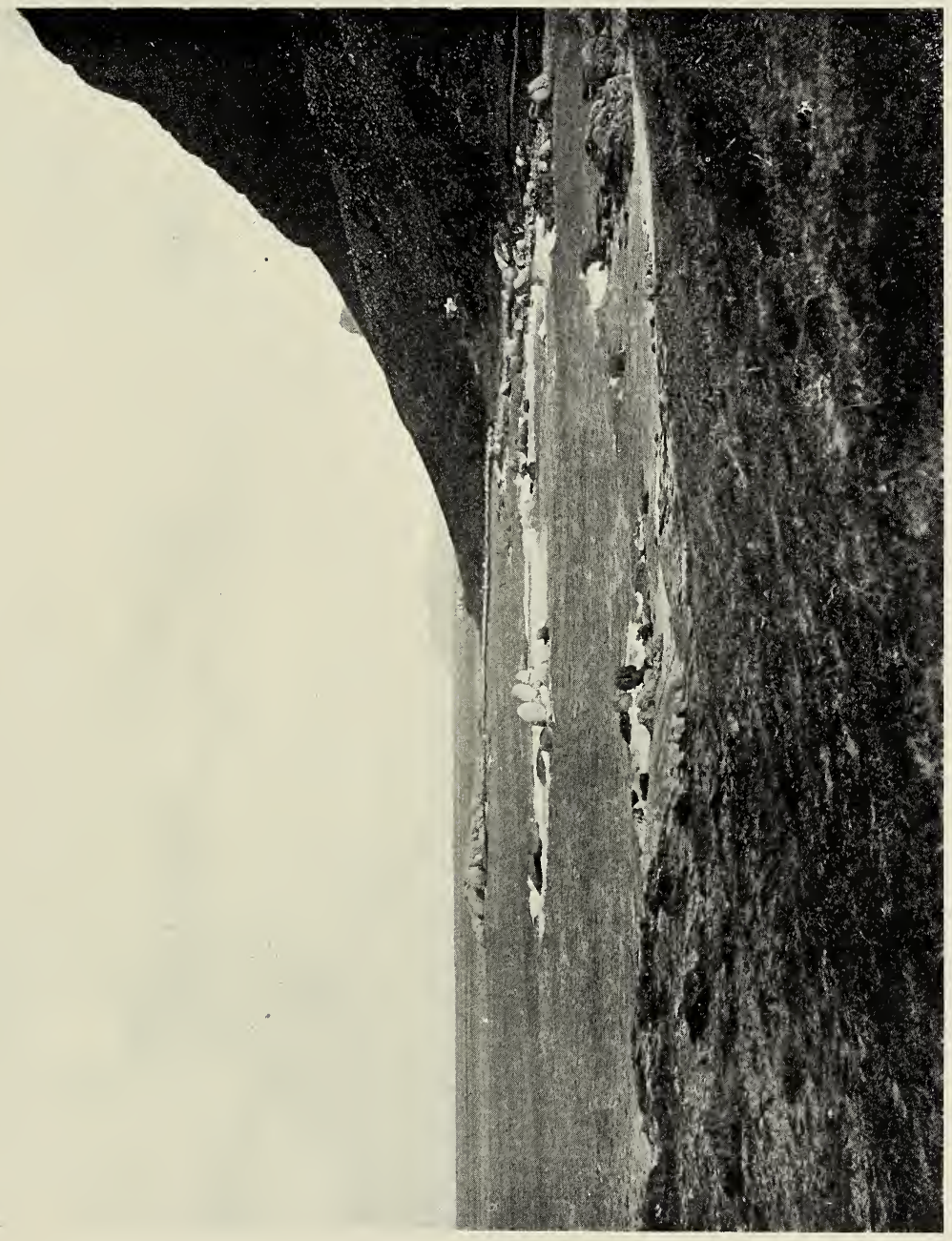



Diary of a Tour in South Africa. 185

The Cape of Good Hope is a short distance round the Point on the Atlantic side, and of course could not be seen. By the time we got back to the car it had become dull and cold, and we were glad enough to stay "at home" for the remainder of the day.

During this drive to Miller's Point, a beautifully sheltered cove was pointed out to us, as the place where some Boer prisoners had been bathing, one of whom had had a leg bitten off by a shark.

\section{June 8.}

We left Simon's Town at one o'clock, and have spent the afternoon in Cape Town. Our wanderings are not quite at an end, as we shall leave here early to-morrow morning for Caledon. Coming from Simon's Town to Cape Town, one passes through Muizenberg, where stands the little cottage in which Cecil Rhodes died. It is shewn to visitors by a 
i 86 Diary of a Tour in South Africa.

Scotch janitor, and bids fair to become, like the Motoppo Hills grave, a place of pilgrimage, a sort of "Burns's Cottage" of South Africa.

Miles from Simon's Town, 25 ; total miles travelled, 7,024.

June 9.

Leaving Cape Town at 8.20 this morning, we have been passing through charming scenery all day, particularly in the neighbourhood of Sir Lowry's Pass, I,37I feet, excellent views being obtained of the coast line of the Cape Peninsula during the ascent, which is negotiated by numerous zig-zags, a type of railway track that we are well accustomed to at this date. The speed at which we travelled was, as usual, not excessive, as we did not reach our destination till 3.30 P.M. Eightyseven miles in seven hours and ten minutes cannot be called dangerous travelling! 
Diary of a Tour in South Africa. 187

This part of Cape Colony is evidently a district in which there is a great preponderance of the Dutch element, in fact, to judge by what we saw of humanity at the various stations, the Dutchman was really more in evidence here than in any other district we passed through during the whole of our travels. We all remarked at the time that our ideas of the character and appearance of the slim Boer, had been more realized in this region (only a few miles from Cape Town) than anywhere else. Little wonder that in the early stages of the last Boer War, a rising of the Dutch in Cape Colony was a factor that had to be reckoned with.

After getting through Sir Lowry's Pass, which crosses the Hottentot's Holland Mountains (a most picturesque range as seen from Simon's Town, on the opposite side of False Bay), the line gradually descends, until Caledon, 800 feet, is reached. There is nothing very 


\section{i 88 Diary of a Tour in South Africa.}

exciting about this place, which is a clean, prosperous-looking, large village, apparently very Dutch, to judge from the general appearance of things, such as the fact that the Dutch church looked a vastly more important edifice than the English church, and also that almost every kind of notice (such, for example, as the office of the School Board) was stuck up in both languages, the Dutch mostly on the "top," a thing we had never seen before. Blue gums are a great feature of the landscape, which consists of fine rolling country, not unlike much of the South Downs.

The outstanding feature of Caledon is its hot mineral springs, in connection with which a large and well-equipped sanatorium has been erected. In the old days, before the opening of the Suez Canal and the diversion of the traffic from east to west, this used to be a favourite resort for people returning from India, suffering from impaired health. There 
Diary of a Tour in South Africa. 189

are seven iron springs-one cold, and six hot, with a temperature of $\mathrm{I} 20$ degrees.

After arranging for the car to be put on a convenient siding, we strolled up to the baths, and, as we liked the look of things, arranged to go back next morning to indulge in the luxury of a bath, with plenty of water. We have got really a nice one in the car, but the Professor and I are always being accused of using too much water, but we were really always most conscientious, and rarely exceeded a depth of two or three inches. Even three inches of depth in a bath is really not just oceans of water, particularly if one is rounding a sharp curve at the time, and the experience of being left high and dry at one end of the bath, with all the water at the other, was quite a common one.

Miles from Cape Town, 87; total railway journey to this date, 7 , III. 
June 1o.

There is little to record about this day's proceedings, beyond the fact that we have had glorious weather for what is really our last day of country life in South Africa,--as to-morrow we return to Cape Town, and shall take a tender farewell of the car, which has been our home for so long. After all the turmoil of these past weeks, to-day has been an ideally restful rural episode, during which we have enjoyed the most perfect security from the attacks of the "Shunter Fiend," whose attentions throughout our long journey have, in every colony we have passed through, been simply beyond description, and I feel convinced if the average "shunter" on a South African railway could be taken home and shewn how tenderly a passenger carriage is shunted on our railways, he would die of a broken heart. Anyhow, his career of crime, as far as we are 
Diary of a Tour in South Africa. igi

concerned, is about at an end, so I need not further "eulogize" him.

This morning we have devoted to our promised visit to the Sanatorium and its mineral baths, in which we really all had a good splash; the Professor and I, with no lingering fear as to a subsequent searching cross-examination as to the exact amount of water we did use. I should like to put on record here that we always tried to speak the truth before our judges in this matter, and in justice to them I must also add that we were never credited with it!

We had lunch at the Sanatorium, and then drifted home in the course of the afternoon, after which I took a number of photographs of the car staff, and the last evening in the car was spent in the usual fashion. 
i92 Diary of a Tour in South Africa.

June II.

Our last night in the car has been a very cold one-at least cold in comparison to the nights we were having only a few days since, about two thousand miles nearer the equator.

We have had a gloriously clear day for the very last stage of our very long journey. Leaving Caledon at 10.35 this morning, we have, on this journey, been obliged to divide our attention between gazing at many lovely stretches of country, and stuffing our goods and chattels into our trunks. It is no joke to stow away one's things in a train, and it certainly cannot be called packing as generally understood, and I was at anyrate duly thankful that the lovely arrangement of the contents of my own trunks, as they left that car, would not have to stand the candid criticism of some rather near relatives of my own, who have 
Diary of a Tour in South Africa. 193

got an idea that they can pack a trunk to advantage.

When we were within an hour or so of Cape Town, the car staff was paraded for "tipping" purposes, and, needless to say, those "tips" were of ample proportions, the "Rev." Auguste receiving his with an extensive grin. After this touching ceremony was over, the question of a testimonial to these three heroes was raised, and I was deputed by our hosts to write them. The documents for Forcioli, the chef, and Clark the steward, I managed without any difficulty, but when I came to consider the form likely to be useful for our versatile chaplain, I at once felt that here was a subject that required more sublime treatment than my poor pen was capable of, in fact, that no one could do justice to this exalted theme but our own Professor, who, with his usual courteous amiability, came to my assistance and did the following graceful panegyric :- 
i94 Diary of a Tour in South Africa.

"To His Holiness Auguste Soles, D.D., etc., Head Chaplain and Chief Bottle Merchant to the Lion Exterminator Society's Expedition, Kafue River, Zambesi, etc.

"Rev. Sir,

"We, the undersigned, desire to express our humble astonishment and admiration at the miraculous manner in which you have overtaken the multifarious duties of your important position.

"Your grasp of the Drink Question in relation to the Coloured Races; your talent for Music as a soothing influence for Peace; your single-eyed devotion to Duty in all its forms; your Democratic instincts, which enable you to sleep peacefully in the Saloons of the Rich or in the fetid atmosphere of the Galley Slums; your Humility in Prosperity; your Proud Bearing in Spiritual Exhaltation; and your modest Self-Effacement when Public Appearance was loudly called for-all, Rev. Sir, encourage us to offer this simple token of appreciation. 
Diary of a Tour in South Africa. 195

"We have never met, seen, or heard of anything like you, and we fear you may long be spared for South Africa as a living proof of what Mission Training can do.

"Scotland is too small a sphere for talents like yours, but we shall never forget you and your peaceful influence, and shall try our best to do without you in the colder clime of Britain, where your tropical nature might not be properly understood.

"With united wishes for your commercial and spiritual success, and for your quiet and painless decease,

"We are, Reverend Sir,

"Your obedient and humble admirers,

"The Professor and The Precious Stone."

These touching domestic episodes being now at an end, the train drew up soon afterwards in Cape Town station, where we were met by Mr. Armour, who arranged for the transference of all our belongings to the Mount Nelson 
ig6 Diary of a Tour in South Africa.

Hotel, where he had engaged rooms for us. After farewells to our staff, which, as between the Professor, myself, and the "Chaplain," the reader will naturally imagine were touching, we drove away to the hotel, and our long railway journey of seven thousand, one hundred, and ninety-eight miles-plus the many miles we had treked over caricatures of roads and trackless veldt-became things of the past.

\section{June $\mathrm{I} 2$.}

It is quite a queer sensation living again in a big hotel; even being able to walk about in one's bedroom is quite a new idea, and quite a pleasant one; but the unnatural stillness of the night, and the comfortable hotel bed, did not add to the soundness of my sleep-rather the reverse. We had a stroll in the town this morning, and in the afternoon drove out to Rodenbosch, which is one of the principal suburbs, and contains many fine mansions and 
GROOTE SCHUUR. 



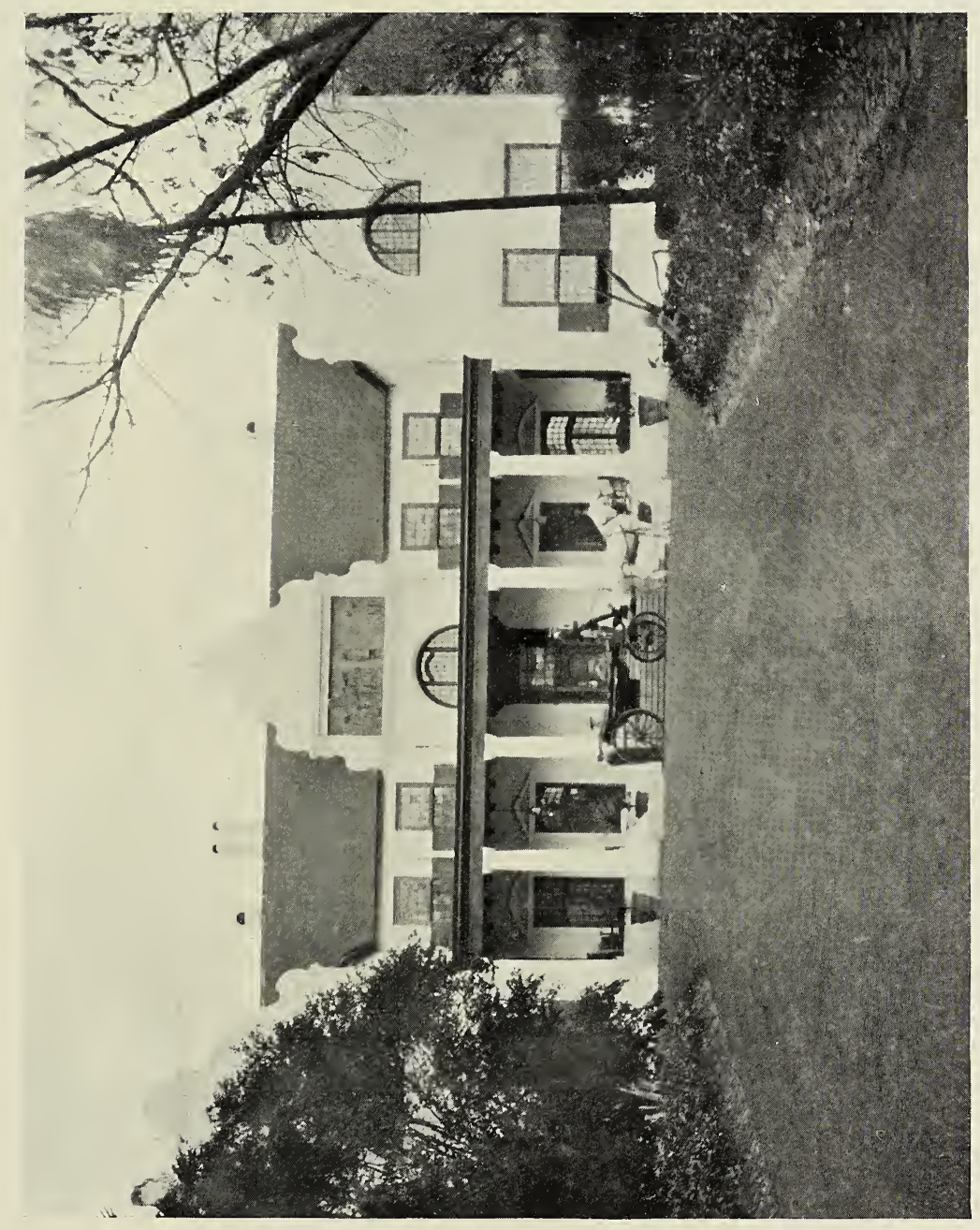



IN THE GROUNDS OF GROO'E SCHUUR. 


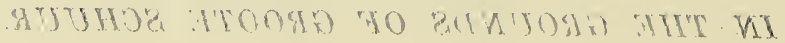




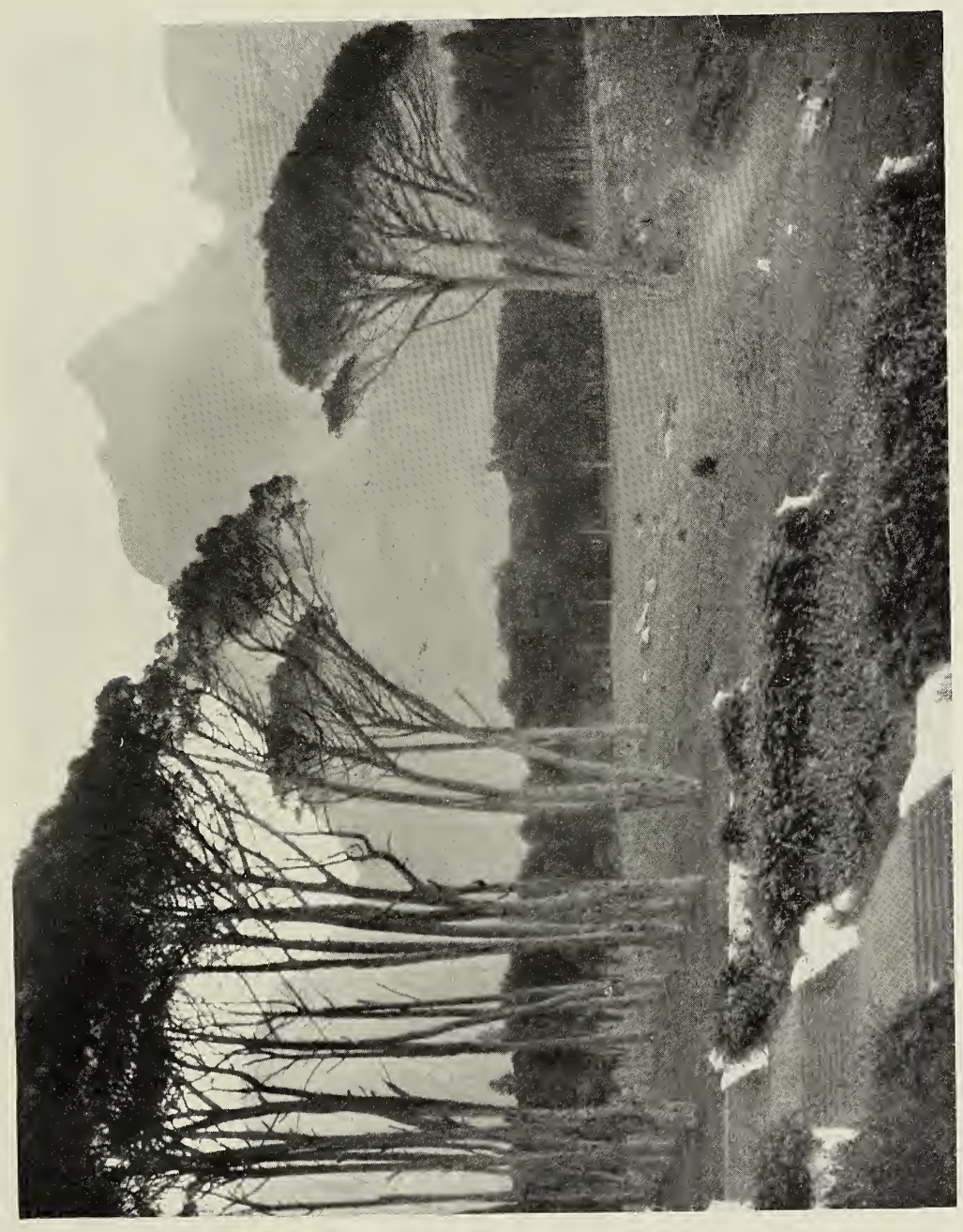



Diary of a Tour in South Africa. 197

villas. Here is situated the mansion of Groote Schuur, the Cape Town residence of the late Cecil Rhodes. It is very well worth a visit, its old-world quaintness being most striking. The view from the back of the mansion, looking towards the eastern extremity of the Table Mountain range, named the Devil's Peak, over 3,200 feet, is indescribably grand; and I am fortunately able to give some idea of its beauty in the reproduction of one of my photographs. Groote Schuur was, unfortunately, much damaged by fire in 1896 , indeed I believe we were told that it had been practically destroyed, but it has been completely restored to its original form, with the exception that the old thatched roof has been replaced by tiles.

We were taken over the house, and found the interior the most interesting part of it. Not only were we struck with the quaintness of the rooms, but also with the beautifully 
i98 Diary of a Tour in South Africa.

carved woodwork to be seen everywhere, and the great quantity of rare objects and things of all sorts which Mr. Rhodes had accumulated.

We saw our first lions in South Africa this afternoon, two big brutes, a lion and lioness, sleepily glancing at us as we came through the park. As our guns were in Cape Town, and as we had neither sticks nor umbrellas with us, it was as well that the sleepy glances came through iron bars. In the grounds are several large enclosures containing numbers of rare animals collected by Mr. Rhodes from all parts of South Africa. In his Will he bequeathed the grounds to the public, and the mansion he left as a residence for the first Governor of United South Africa. Needless to say, we returned to our hotel very much pleased with our afternoon's outing.

In the evening we had a visit from Mr. Andrew Coats, and it was arranged that we should all call on Mrs. Coats' father and 
Diary of a Tour in South Africa. 199

mother, who live in Cape Town, to-morrow afternoon.

June 13. Sunday.

As my intimate friends are aware, I am a most exemplary church-goer in my own country, not that I ask, or even get, any credit for my regular attendances from my acquaintances. Anyhow, this lapse of the past few months from my regular habits will probably still make my yearly average compare very favourably with the bulk of my friends. This introduction is merely to chronicle that I did go to church this morning, and heard a really good service at Cape Town Cathedral. It contains a good organ, very well played, and the boys' voices were, I think, equal to, or perhaps better, than I have ever heard in our own Cathedrals. There seemed to be a particular purity in their voices, whether caused by the dry air of South Africa or not I cannot say, but I was 
200 Diary of a Tour in South Africa.

much impressed. May be I was in a specially good mood to be impressed, having during these past months listened to nothing more enthralling than the seraphic strains of our tin whistle artist, our reverend and already lost-tosight chaplain.

St. George's Cathedral is an ugly building of the four walls and a roof type. A guide book says it was built in 1830 , when English architecture was at a low ebb. I quite believe that guide book; nor did I photograph that Cathedral. A new Cathedral is, however, in course of erection, the cost of which is estimated to exceed $£ 200,000$. From what one could see of it, it promises to be a Cathedral worthy of the name; but from what we were told by residents, it is unlikely to be finished for some time to come, owing to scarcity of money.

On my return to lunch, I tried to interest my travelling companions in what I had heard, and they blandly asked me the "text"! 
Diary of a Tour in South Africa. 20I

The Town Hall, Parliament House, and the Post Office are all most imposing buildings, and there are many others worth notice.

In the afternoon we all visited $\mathrm{Mr}$. Andrew Coats' relatives, staying for afternoon tea, which seemed to bring us quite back to civilization again; and in the night the Professor and I were both badly bitten by mosquitos.

June 14 and $\mathrm{I} 5$.

There is really nothing to chronicle about these days, which were devoted to a little shopping and getting ready generally for the voyage home.

June 16.

Soon after breakfast our trunks were sent away to the S.S. Briton, and it gave one quite a cheerful sensation to see them all labelled 
202 Diary of a Tour in South Africa.

"England." We followed about twelve o'clock, and on getting on board were warmly welcomed by our old friend Captain Brown and his officers. We found Mr. and Mrs. Andrew Coats and their daughters, who are going to England on a visit, already aboard, and we all soon got settled down in our cabins-our hosts and their relations on the upper deck, and the Professor and myself up on the promenade deck, where, it being the slack season, we each managed to get a roomy cabin to ourselves, the luxury of which is very great when one gets into the hot weather, and our hosts were equally fortunate on their deck. Seeing that each of us had had a roomy cabin for himself on both voyages, I think I should mention that we considered that the Union Castle Company had certainly done very well for us.

While we waited to sail, I made a number of attempts to get photographs of Table Mountain, but that everlasting "table-cloth," as they 
Diary of a Tour in South Africa. 203

call it, was always hanging over the top of the mountain, and it quite baffled me. The Devil's Peak and Lion's Head also had continuous clouds on their tops. My special desire was to get a good photograph from the sea, but when we got under weigh at 4.30, I lost my chance of getting a picture; and then the thing happened which usually does happen under such circumstances. As soon as we were too far out for a photograph to be possible, the "table cloth" removed itself from Table Mountain, and the other two peaks came out quite sharp against the sky.

We watched the African Continent fade away with some feelings of regret, as we had had some jolly times within its borders. By this time we were out into the open, and the ship was rolling heavily, which it continued to do all night, at least until I slept. 
June 17 to 27 .

We rose this morning to find the sea much quieter, that heavy roll coming up from the south-west having nearly spent itself. There is little use to particularize the days of a voyage like this. As usual, the days became hotter as we neared the equator, and cooler as we left it; as usual, the leaping dolphins and flying fish appeared in the ocean around us; and, as usual, the customary flirtations appeared on the promenade deck and in odd corners of the ship-indeed, the question of latitude didn't greatly affect "them"!

We have several celebrities on board, going over to attend a Conference to be held in London, in connection with the proposed union of the South African colonies, which was soon to become an accomplished fact. The most important people were the Earl and Countess of Selborne, the Earl at that time being the 
Diary of a Tour in South Africa. 205

representative of the King in South Africa. We heard everywhere that they were much liked in the colonies, and I can well understand it, as they seemed to have a knack of making themselves most agreeable to all on board the Briton. I think we all had a chat with his Lordship during the voyage-certainly not brought about by any effort of our own, as our friends who know our extremely modest and retiring natures may well suppose! One evening I was a listener to a discussion between the Countess and the Laird, the subject being mainly on the policy of the Chartered Company, which I found most interesting from the fact that both parties to the discussion seemed to know what they were talking about, and were not quite in agreement.

We have also the Lord Chief Justice Villiers of Cape Colony, who is to be chairman of the Conference in London. There is 
also Mr. Schreiner, brother of Olive Schreiner, who is going over to look after the interests of the native races in the coming Conference, and also a number of less distinguished people.

June 28.

We are now getting into cooler weather in the region of the Islands. About mid-day we were well abreast of Gomera, twenty miles south-west of Teneriffe, and its precipitous coast and mountainous interior were a grateful sight for the eye to rest upon after twelve days of nothing but ocean. Columbus lived in this island before he started on his quest of the New World. Ever since breakfast, we had been watching for the Peak of Teneriffe, I I,050 feet, which is often enveloped in clouds, and it was most fortunate that during our passage between Gomera and Teneriffe, the clouds dispersed, and we had an uninterrupted 
AT FUNCHAL, MADEIRA. 



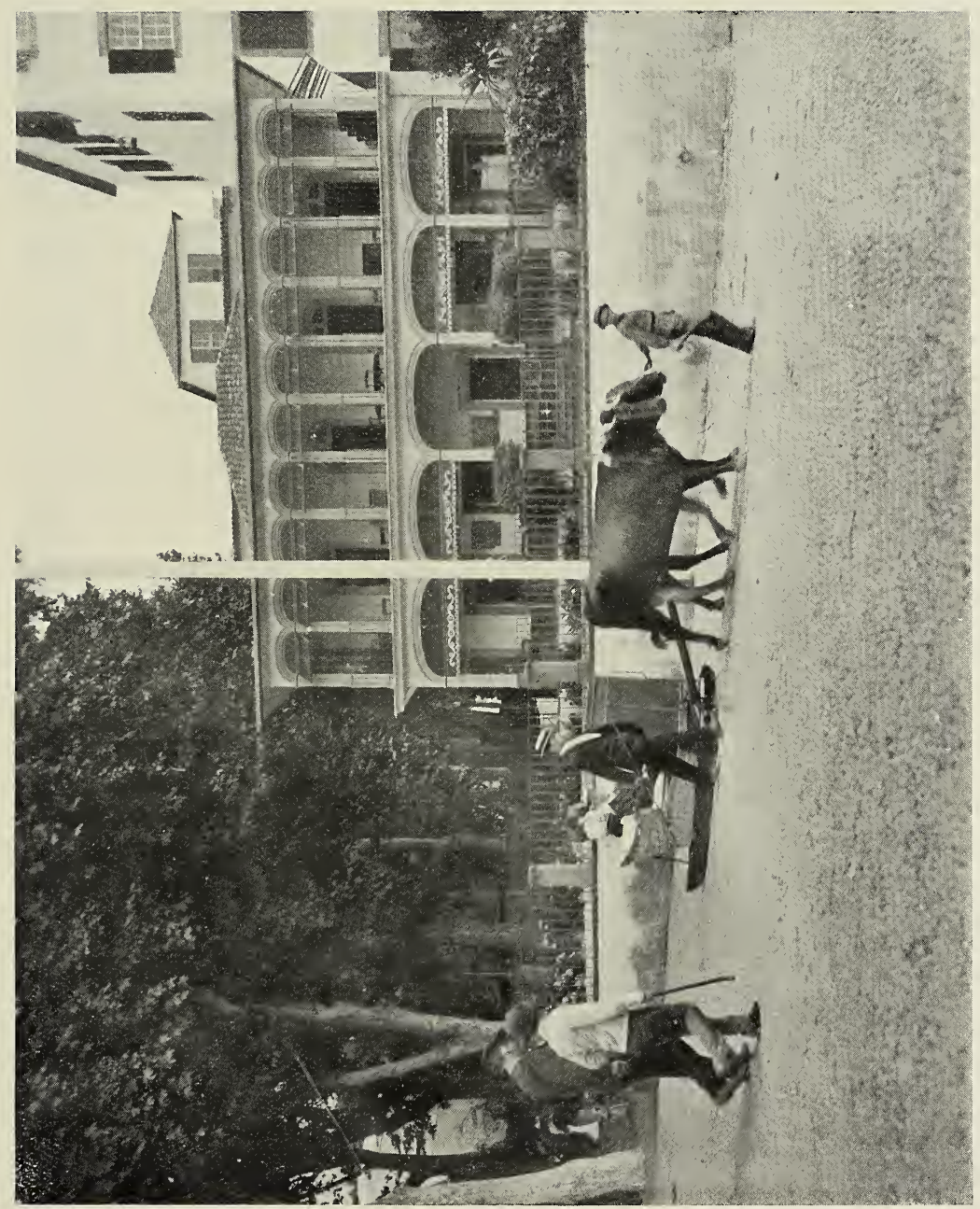



Diary of a Tour in South Africa. 207

view of the Peak for fully a couple of hours, indeed, until it began to fade in the distance.

June 29. Madeira.

This time we have managed to arrive here on a gloriously fine day, not that Madeira is wanting in fine days; but our arrival off Funchal on the outward voyage had been marked by such an intensely disagreeable display of fog and drizzle, quite of the homeland pattern, that we naturally felt extra grateful for its absence this morning.

We must have come to anchor fairly early, as when we turned out of our cabins about seven o'clock, we found the promenade deck thickly strewn with wares of all kinds, such as embroidery, lace, wicker chairs, etc., etc.-the usual litter, at anyrate from the ordinary man's point of view, but which seemed to possess considerable interest for most of the other sex. 
208 Diary of a Tour in South Africa.

The traders from the shore looked to me to be a proper set of scoundrels. Personally I had no transactions with them, nor did any of our party, but I watched a number of dealings, and it was the old story of the Eastern bazaars, as it seemed to me that these honest merchants were generally glad enough to take the half of what they began by demanding!

As the Briton was timed to sail again at eleven o'clock, we left the ship as soon after eight as we could manage to get a boat for the shore. On arrival there, we found our way to the station inside a motor car, and were very soon at the top of the hill or "Mount," as it is called, by means of the cog-wheel railway. There is a splendid and very extensive view from the top, the S.S. Briton lying at anchor appearing to be about the size of a torpedo destroyer. We had breakfast of a rather stodgy nature at Reid's Hotel, and after being pestered as usual by crowds of picture post- 
Diary of a Tour in South Africa. 209

card vendors, we made the descent in toboggans. I don't know whether there are ever any accidents with these clumsy creations, but I could see no reason why there shouldn't at times be a good smash up. Altogether, Funchal seemed to be a more than ordinary dirty spot, and it certainly needs revolution of a kind, and one hopes that what has since happened to its owner, Portugal, may inaugurate a better state of matters, which probably is doubtful.

We sailed soon after eleven this morning, and there is at present every prospect of a pleasant voyage to Southampton.

June 30 to July 2.

The remaining days of the voyage have been quite uneventful. The Bay was, as usual, as far as my experience goes, fairly smooth and enjoyable. Whilst we were crossing, I happened to say to one of the quartermasters, "This is my third passage across the Bay, and 
it seems a nice, calm sort of place," and the weather-beaten old chap replied, "Well, I've crossed it about three hundred times, and I've never seen it rough." And he really had a very honest, truthful look about him! We gathered that this voyage from the Cape could be done in much less time by most of the vessels of the Union Castle fleet. Anyhow, we have been going slowly for several days, in order not to reach Southampton too soon, I suppose. My notes show that from the i 8 th to the 23 rd we were doing, roughly, 400 miles in the twenty-four hours, and now for some days 350 miles has been about the limit, and one day we did a leisurely 297 miles. This evening, just before turning in, we are seeing one or two lights on the coast of Old England, which makes one suppose we are not steaming a particularly straight course for the Needles, and one can feel that the vibration in the engine room is not excessive. 
A HARD-WORKING QUARTET. 


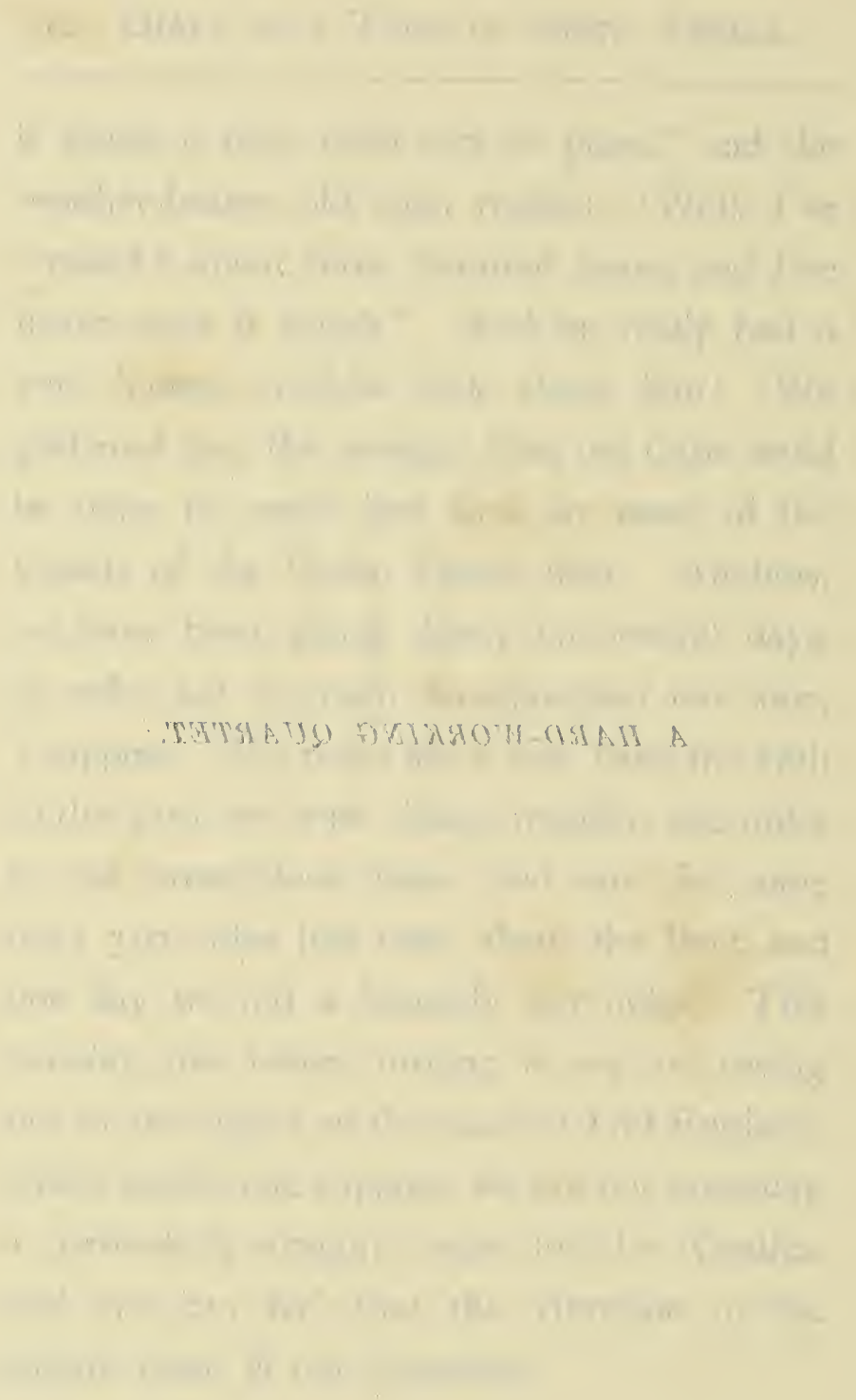




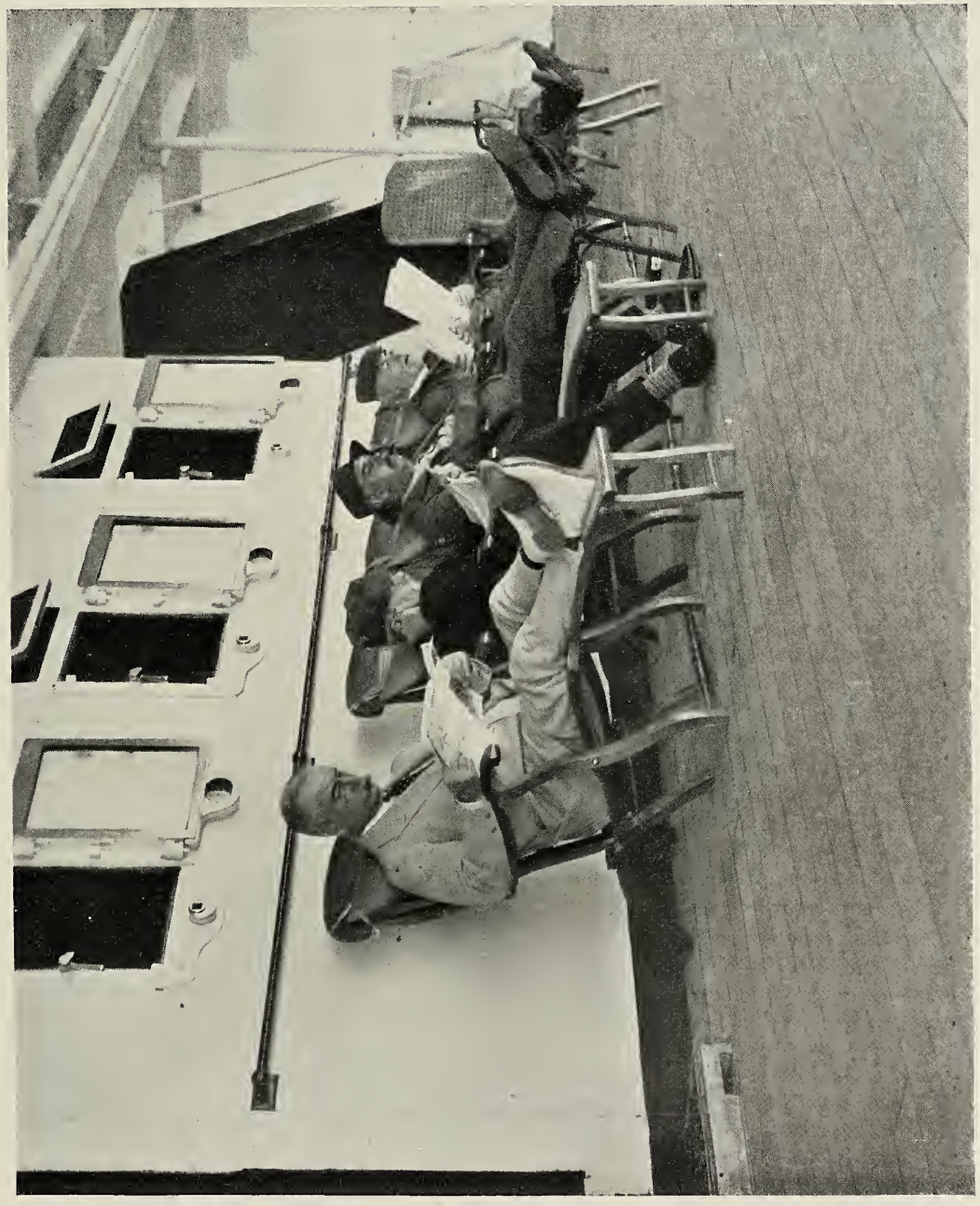



July 3 .

The blast of the fog-horn wakened me this morning, and in looking out of the port-hole I could make out that we were creeping up Southampton Water in a thick mist. It was not long before we were alongside the jetty, and in a shorter space of time than one would imagine, all our trunks had been passed through the Custom House. Major Chichester had come over from Embley Park to welcome the travellers, bringing a couple of motor cars, and after having said good-bye to our very good friend, Captain Brown (an ideal skipper), we were soon whirling over that excellent road to Romsey. As one sped along on its smooth surface, one could not help recalling various tracks, politely called roads, that we had negotiated in that now distant continentroads, which I assure my friends I shall not easily forget. The transition from the arid, 
2 I 2 Diary of a Tour in South Africa.

leafless veldt of South Africa in mid-winter, to all the glorious greenery of Hampshire at mid-summer, in the space of just a month, is an experience worth having, and never to be forgotten.

We all received a very warm welcome at Embley Park, Mr. and Mrs. Andrew Coats and their daughters being quite enchanted with the beauties of this typical example of one of the lovely country homes of England. The three ladies were visiting Europe for the first time, and it certainly was an excellent introduction to a particular type of country life for which England, with its beautifully wooded parks, is famous. Major and Mrs. Chichester gave us a jolly week end, and as we are all going to London in the morning, I had better bring this rather long story also to an end to-night.

It has been a long journey: the total, including sea voyage, railway, motor car, and 
A "PROMENADE" AT SIMON'S TOWN, SOUTH AFRICA. 


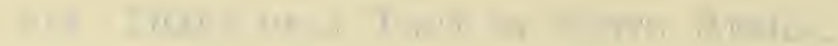

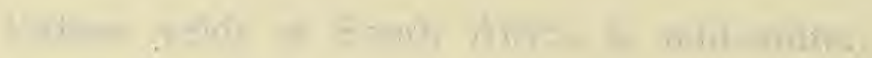

When ine

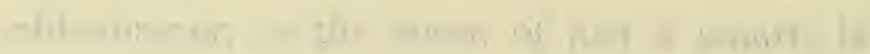

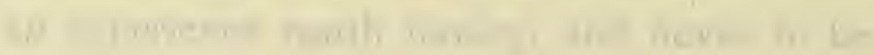

$+3+2 y$

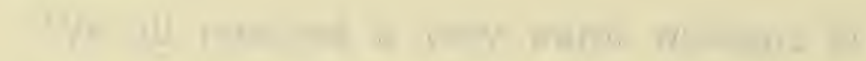

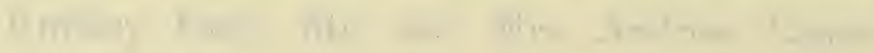

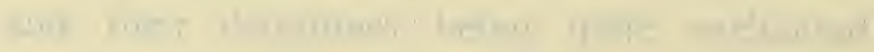

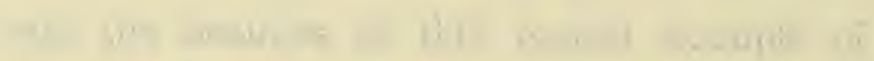

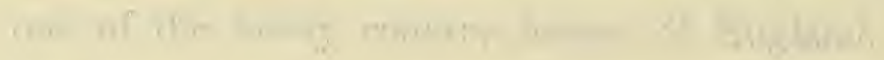

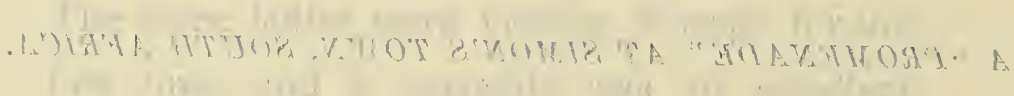

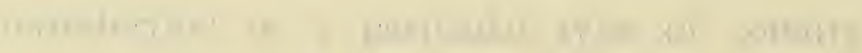

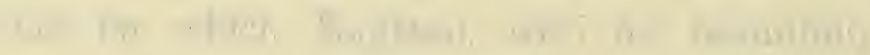

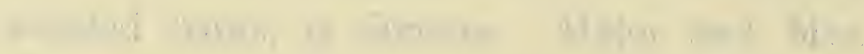

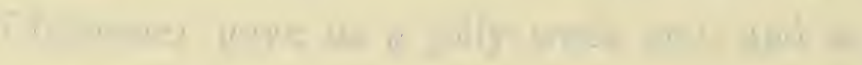

W.

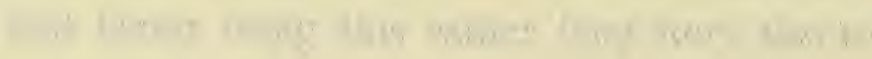

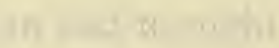

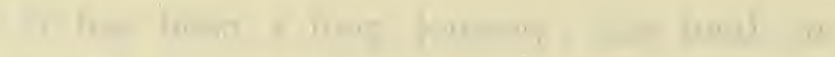

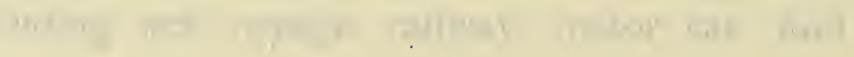




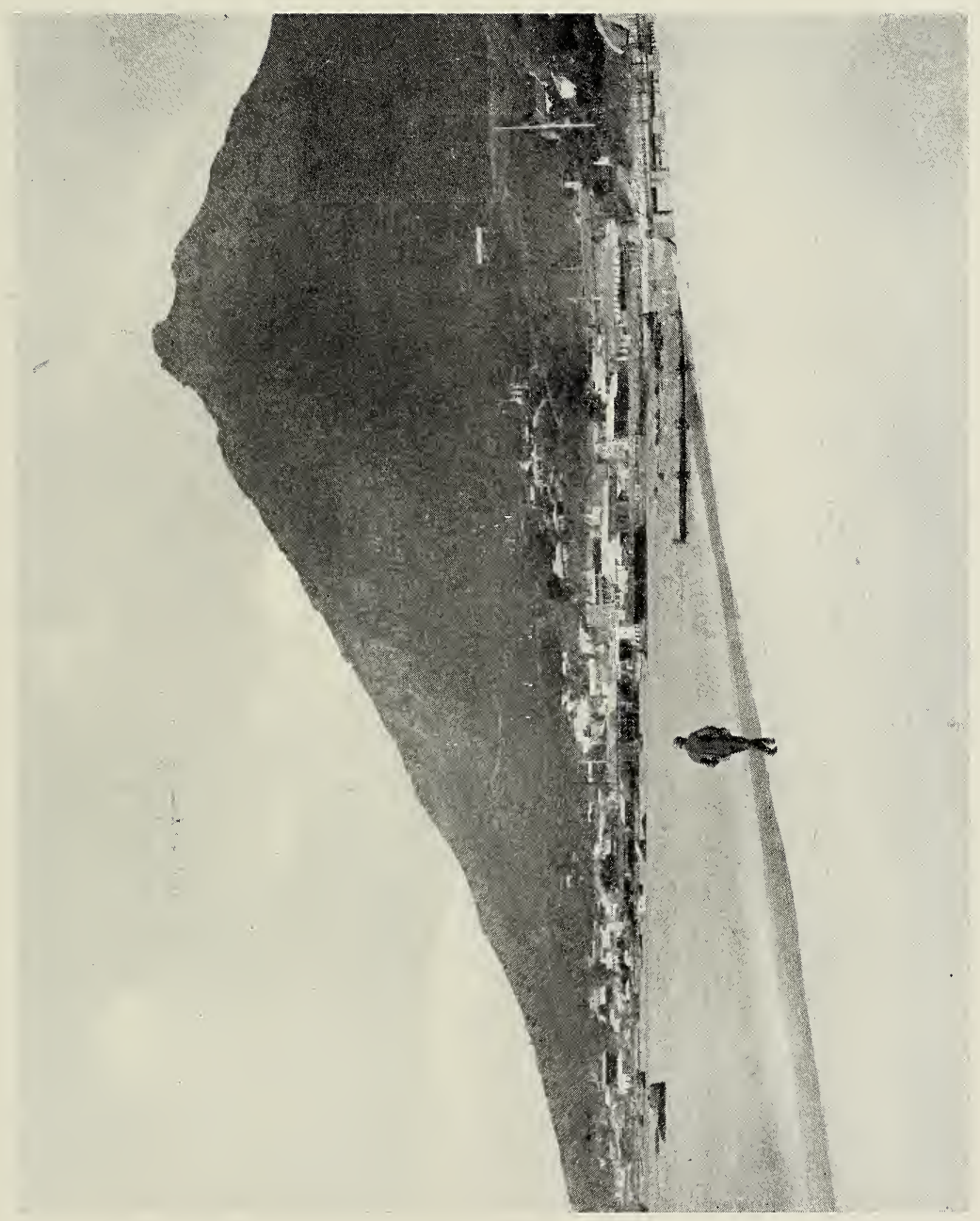



A “PROMENADE" AT EMBLEY PARK, HANTS. 


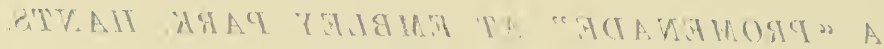




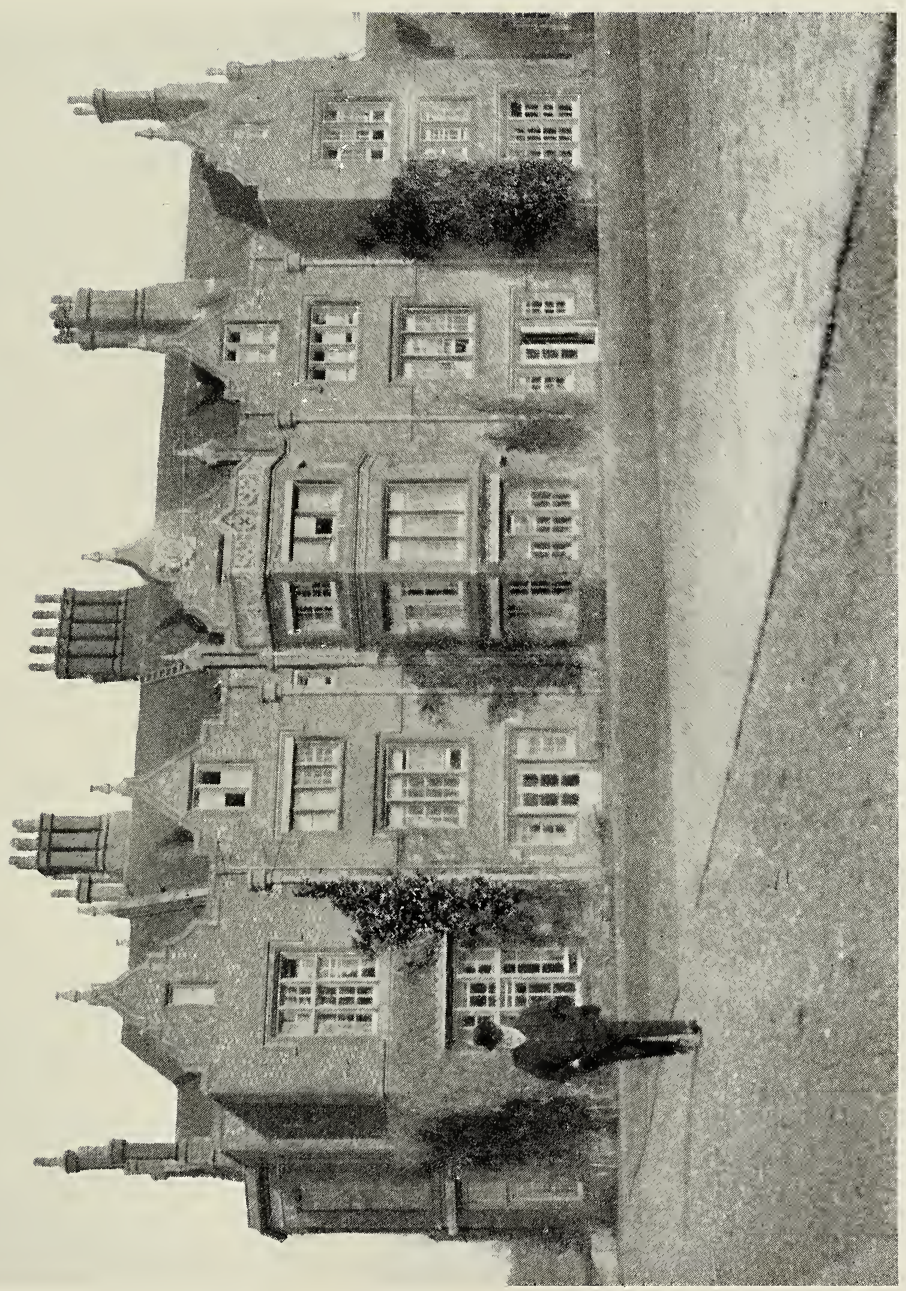



Diary of a Tour in South Africa. 2I 3

Cape cart journeys, will, by the time we get home, not be less than twenty-one thousand miles in all. We can now claim to know something of the African Continent, having been a thousand miles in at the north end, and two thousand miles at the south. It is scarcely likely that either of us will ever do that little stretch of three thousand miles between Wady Halfa and the Zambesi, but having seen so much, it requires very little imagination to form a pretty good idea of what the remainder of that Cape to Cairo journey would be like.

In closing, I don't want to be personal, but I cannot refrain from saying that our kind hosts allowed us to want for nothing, as I am sure Royalty could not possibly have travelled in such out-of-the-way spots in greater comfort than we did; and long shall we remember our almost nightly game of bridge in the solitude of the vast veldt, and at times amidst the noise of railway goods'-yards - times when 
214 Diary of a Tour in South Africa.

that "Precious Stone's" play was often the object of ribald jeers, and times when our worthy senior host, in the paradoxical character of "dummy," favoured us with perpetual orations, and blandly took entire charge of the game. These little episodes, together with the always inspiring influence of the cheerful stories of our ever amiable Professor, are things that must linger with us all as very pleasant remembrances.

THE END. 







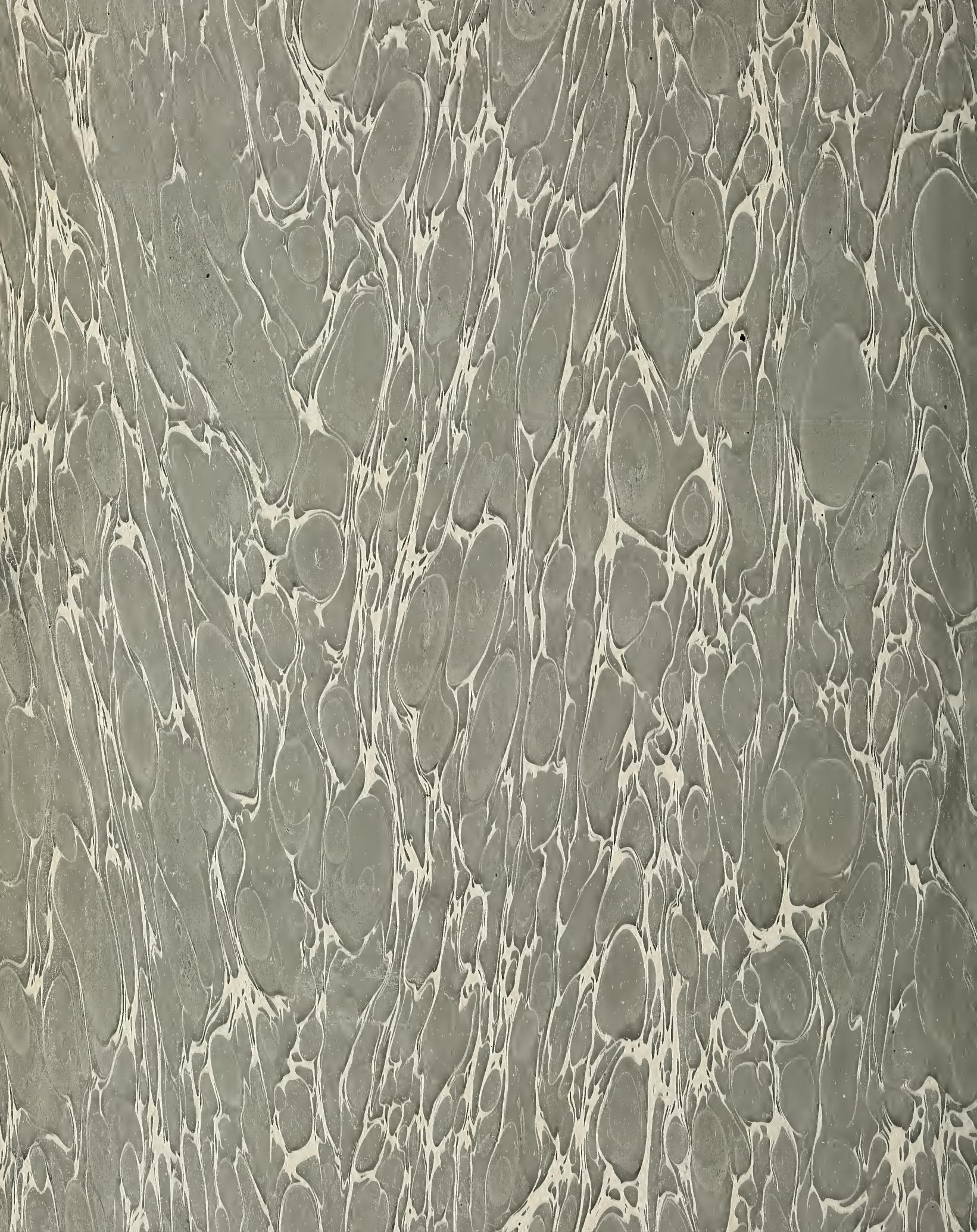




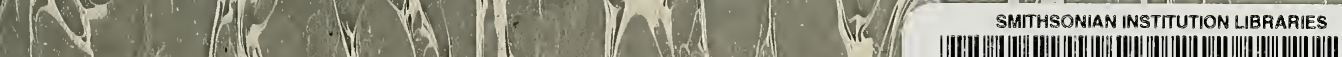
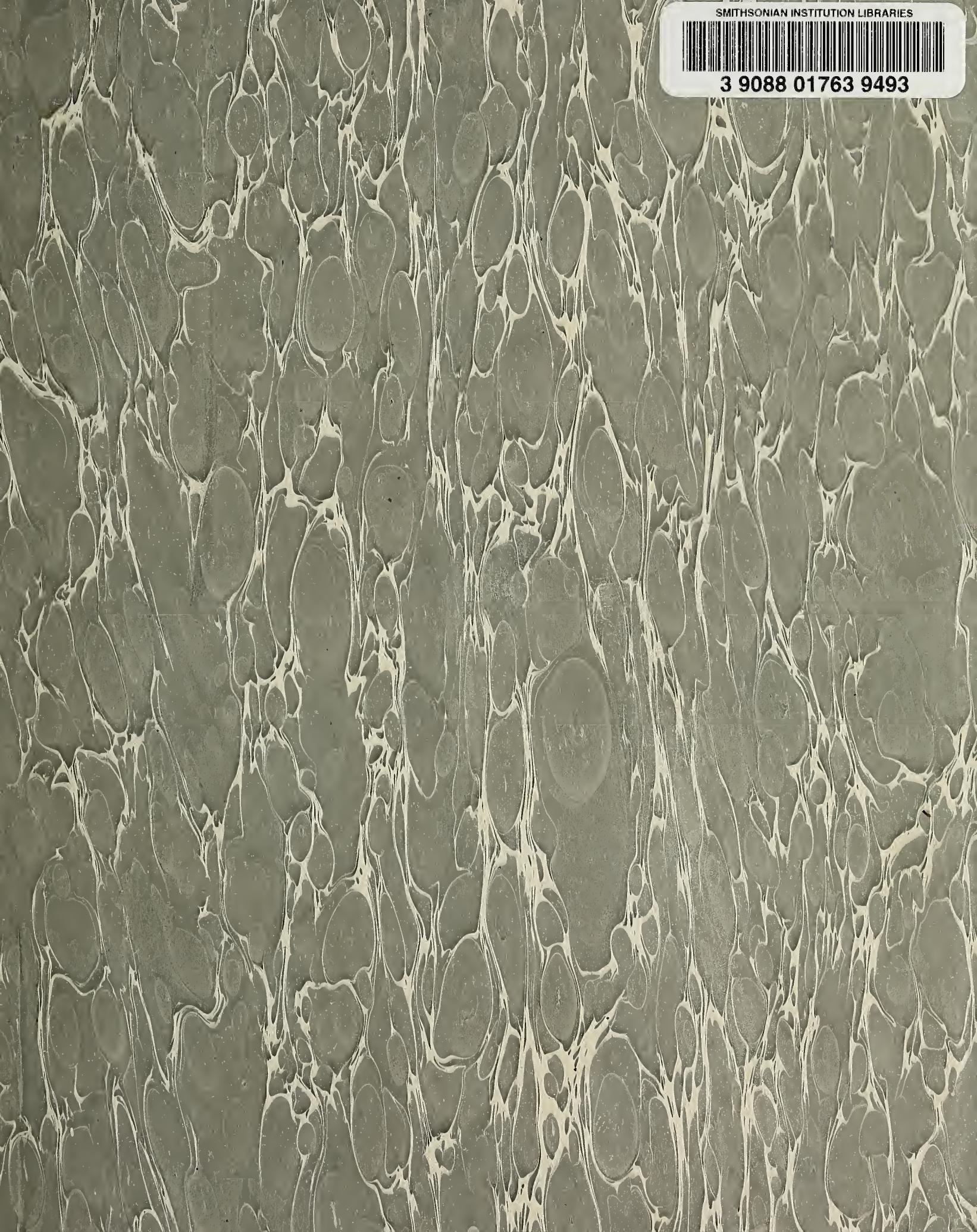
(1)

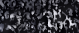

(9.)

(4)

\section{$3 \times$}

$\sin ^{2}+x^{2}$

\section{(3)}

H.t.

tis.

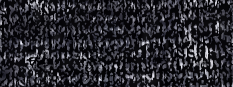

\section{7.}

$\log x$

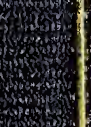

